\title{
Origin, fate and detection of methane leaking from the deep subsurface into groundwater and soil
}

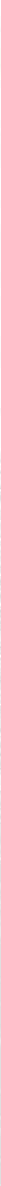

Gilian Schout 



\section{Origin, fate and detection of methane leaking from the deep subsurface into groundwater and soil}

Oorsprong, lot en detectie van methaan lekkage vanuit de diepe ondergrond naar grondwater en bodem

Gilian Schout 
Copyright 2020 ๑ Gilian Schout

ISBN: 978-94-028-2076-8

Cover picture: Nationaal Archief/Collectie Spaarnestad/Cevirum/G.A. van der Chijs Design and layout: Legatron Electronic Publishing, Rotterdam

Printing: Ipskamp Printing, Enschede

No part of this thesis may be reproduced, stored in a retrieval system or transmitted in any form or by any means without permission from the author or, when appropriate, from the publishers of the publications. 


\title{
Origin, fate and detection of methane leaking from the deep subsurface into groundwater and soil
}

\author{
Oorsprong, lot en detectie van methaan lekkage vanuit de diepe \\ ondergrond naar grondwater en bodem \\ (met een samenvatting in het Nederlands)
}

Proefschrift

ter verkrijging van de graad van doctor aan de Universiteit Utrecht op gezag van de rector magnificus, prof.dr. H. R. B. M. Kummeling, ingevolge het besluit van het college voor promoties in het openbaar te verdedigen op vrijdagmiddag 10 juli 2020 des middags te 2.30 uur

door

\section{Gilian Schout}

geboren op 25 januari 1988

te 's Gravenhage 


\section{Promotoren:}

Prof. dr. J. Griffioen

Prof. dr. S. M. Hassanizadeh

\section{Copromotoren:}

Dr. N. Hartog

The research in this thesis was carried out as part of the research program 'Shale Gas and Water' with project number 859.14 .001 , financed by the Dutch Research Council (NWO). 


\section{Abstract}

Oil and gas development can cause unintended connectivity between the deep subsurface and shallow aquifers. Methane leaking through such connections can result in groundwater contamination, greenhouse gas emissions, and can constitute an explosion hazard. When leaking methane enters into groundwater and soil systems it is subject to a number of processes that can retain it, degrade it, and alter its molecular and isotopic signature. This signature is used for environmental fingerprinting of methane origin, and can be further changed by mixing of leaking methane with naturally occurring biogenic sources. Together, the combination of those processes makes detection of leakage through surficial flux measurements or groundwater sampling challenging.

In this work, the fate of methane leaking from oil and gas reservoirs into the environment was studied using a combination of scientific approaches, including groundwater sampling and analysis of dissolved gasses and isotopic tracers, soil gas flux measurements, and multiphase numerical modelling. Additionally, the occurrence of methane leakage at legacy gas wells in the Netherlands was investigated, together with a characterization of the natural distribution and origin of methane in groundwater in the Netherlands. Based on this combined hydrogeochemical investigation, the study provides further insight into the risks of methane leakage, and the processes that control its migration through the subsurface. 


\section{Contents}

Chapter 1 | Introduction 9

1.1 | Methane leaking from the deep subsurface into groundwater $\quad 10$ $\begin{array}{ll}\text { and soil } & 10\end{array}$

$\begin{array}{ll}1.2 \mid \text { Methane geochemistry } & 11\end{array}$

1.3 Construction and abandonment of oil and gas wells 13

1.4 | Well failure and methane leakage $\quad 17$

1.5 | History of oil and gas production in the Netherlands 18

1.6 | NWO shale gas and water research program $\quad 20$

$\begin{array}{ll}1.7 \mid \text { Research aims and thesis outline } & 21\end{array}$

Chapter 2 | Controls on groundwater methane occurrence and origin from 27 shallow aquifers to deep formation waters in the Netherlands

2.1 | Introduction $\quad 29$

$2.2 \mid$ Hydrogeology of the Netherlands 33

$2.3 \mid$ Methods $\quad 36$

$2.4 \mid$ Results and discussion $\quad 40$

$2.5 \mid$ Conclusions $\quad 56$

Chapter 3 | Occurrence and fate of methane leakage from cut and buried $\quad 67$ abandoned gas wells in the Netherlands

$3.1 \mid$ Introduction $\quad 69$

3.2 | Materials and Methods $\quad 71$

$3.3 \mid$ Results $\quad 76$

$3.4 \mid$ Discussion $\quad 83$

$3.5 \mid$ Conclusions

Chapter 4 | The impact of an historic underground gas well blowout on the current methane chemistry in a shallow groundwater system

4.1 | Introduction $\quad 99$

4.2 | Hydrogeological setting $\quad 100$

4.3 | Methods 102

4.4| Results and discussion 105

4.5 | Conclusions 111 
Chapter 5 | Impact of groundwater flow on methane gas migration and retention in unconsolidated aquifers

5.1 | Introduction

5.2 | Material and Methods 123

5.3 | Results 130

5.4 | Discussion 140

5.5 | Conclusions

6.1 | Introduction 154

6.2 | Summary of main findings 154

6.3 Origin and distribution of groundwater methane in the Netherlands 156 6.4 | Fate and detection of methane leaking from the deep subsurface 162

$6.5 \mid$ The risks of methane leakage in the Dutch context 169

Summary

Samenvatting 185

List of Publications 191

Dankwoord 193

Curriculum Vitae 



\section{CHAPTER}

Introduction 


\subsection{METHANE LEAKING FROM THE DEEP SUBSURFACE INTO GROUNDWATER AND SOIL}

Development of oil and gas resources in the deep subsurface can result in unintended connections with overlying groundwater aquifers when the vertically isolating function of the geological barriers that are penetrated are compromised. Through these anthropogenic connections, upward leakage of natural gas, oil, formation water and/or production fluids may occur, which can result in contamination of valuable water resources. Due to the buoyant force that acts on natural gas, leakage of natural gas to groundwater is observed much more frequently than leakage of other, heavier fluids (Wisen et al., 2019). As methane is the main component of natural gas $(<90 \%)$, such leakage is often referred to simply as methane leakage. Although ingestion of methane containing groundwater is not toxic (Vidic et al., 2013), the introduction of methane into pristine groundwater can lead to a deterioration of groundwater quality (Kelly et al., 1985). Furthermore, methane leakage can also form an explosion hazard when allowed to accumulate in confined spaces (Miyazaki, 2009). Therefore, groundwater containing dissolved methane has to be additionally treated before it can be safely sent into water distribution systems. Lastly, significant amounts of methane leaking through improperly sealed wellbores may eventually reach the atmosphere (Kang et al., 2014), where it acts as a 28 times more powerful greenhouse gas than $\mathrm{CO}_{2}$ (Myhre et al., 2014).

Methane leakage from the deep subsurface to shallow groundwater and soil systems has been a known issue in the oil and gas industry for decades (Erno and Schmitz, 1996; Harrison, 1983). However, societal concern about its environmental impact rose significantly following the rapid rise in production from unconventional shale reservoirs and the associated increase in well drilling in the US since the 2000s, enabled by innovations in hydraulic fracturing and horizontal drilling techniques (Jackson et al., 2014). Contributing to these concerns, a number of studies analysing methane in groundwater overlying the Marcellus Shale in Pennsylvania, USA, found that elevated methane concentrations were correlated to proximity to shale gas wells (Jackson et al., 2013; Osborn et al., 2011). They subsequently showed that leakage from the reservoir depth to the investigated aquifers occurred through conduits in the cement and steel casings of the wellbore system itself, rather than through fractures induced by hydraulic fracturing (Darrah et al., 2014). This type of wellbore failure can be a common occurrence, although widely varying incidence rates ranging from $1.9 \%$ to $75 \%$ have been reported depending on the oil and gas field and well construction practices (Davies et al., 2014). On the contrary, leakage through induced fractures is deemed much less likely (Dusseault and Jackson, 2014), as the vertical extent of hydraulically induced fractures is typically way shorter than the distance between shallow aquifers and the hydrocarbon reservoirs (Davies et al., 2012).

At the same time, methane may also be present naturally in shallow groundwater as a result of in-situ methanogenesis coupled to the microbial degradation of organic matter (Whiticar, 1999). In fact, other researchers investigating methane in the aquifers above the 
Marcellus Shale concluded that regional concentrations were not linked to anthropogenic activities but rather occurred naturally and were controlled by the topographical and hydrogeological position of sampled wells (Molofsky et al., 2013, 2011). Furthermore, methane in shallow groundwater may also result from leakage through naturally occurring faults and fractures. However, such natural macro-seeps are only observed for a relatively small subset of oil and gas reservoirs (Etiope et al., 2009). To properly assess the environmental impact of methane leakage and to put forward effective mitigation strategies, there is a clear need to distinguish between the various origins of methane in groundwater in oil and gas producing regions world-wide. Then, when methane from deep sources is identified, the possible migration pathways need to be assessed in order to attribute either a natural or anthropogenic source.

\section{2 | METHANE GEOCHEMISTRY}

Methane is formed in the subsurface as the result of the breakdown of sedimentary organic matter. In the shallow subsurface, at temperatures up to $75^{\circ} \mathrm{C}$ (Clayton, 1991), methanogenesis is mediated by archaea and bacteria. Such biogenic or microbial methane only forms under anoxic conditions when all other (major) electron acceptors are depleted, in order: $\mathrm{O}_{2}, \mathrm{NO}_{3}, \mathrm{MnO}_{2}, \mathrm{Fe}(\mathrm{OH})_{3}$ and $\mathrm{SO}_{4}$. Hence, it does not form in groundwater in shallow unconfined aquifers where oxygen is abundant. The two main pathways through which biogenic methane may be formed are the reduction of carbon substrates such as methylcompounds or acetate:

$$
\mathrm{CH}_{3} \mathrm{COOH} \rightarrow \mathrm{CH}_{4}+\mathrm{CO}_{2}
$$

and $\mathrm{CO}_{2}$ reduction by free hydrogen:

$$
\mathrm{CO}_{2}+4 \mathrm{H}_{2} \rightarrow 2 \mathrm{H}_{2} \mathrm{O}+\mathrm{CH}_{4}
$$

The first pathway, often referred to simply as 'acetate fermentation', is most common in recent freshwater sediments. In marine sediments, high sulphate concentrations initially allow sulphate reducing bacteria to outcompete methanogens for the available reactive carbon. Once sulphate is depleted, $\mathrm{CO}_{2}$ reduction typically becomes the dominant process, due to depletion of carbon substrates and the availability of dissolved bicarbonate formed during sulphate reduction (Whiticar, 1999). The required free hydrogen is produced through symbiosis with fermentative bacteria (Schink, 1997). Depending on the geochemical conditions, these two pathways may occur simultaneously. Their relative importance can vary between $100 \%$ acetate fermentation to close to $100 \% \mathrm{CO}_{2}$ reduction (Appelo et al., 2004). 
Methanogenic breakdown of organic matter may also occur at greater depth as part of thermocatalytic natural gas generation (i.e. cracking). Classically, natural gas is believed to form most effectively at temperatures exceeding $150^{\circ} \mathrm{C}$. At temperatures ranging from 100 to $150^{\circ} \mathrm{C}$ methane can be coproduced with oil at mass ratios of about 0.2 (Clayton, 1991). However, the catalytic generation of methane has been shown to be possible at temperatures as low as $60^{\circ} \mathrm{C}$ (Wei et al., 2018).

The molecular and isotopic composition of methane containing gasses dissolved in groundwater are used to distinguish between these various origins, and identify sources of methane contamination and leakage. Larger alkanes are much more abundant in thermogenic gas resulting in so-called dryness ratios $\left(C_{1} /\left(C_{2}+C_{3}\right)\right)$ below 100 . On the contrary, while small amounts of ethane and propane may be coproduced with biogenic methane (Hinrichs et al., 2006), the gas dryness ratio of biogenic methane typically exceeds 1000 (Whiticar, 1999). Similarly, both the carbon $\left(\delta^{13} \mathrm{C}-\mathrm{CH}_{4}\right)$ and to a lesser extent the hydrogen $\left(\mathrm{DD}-\mathrm{CH}_{4}\right)$ isotopic composition of biogenic methane are distinct from that of thermogenic methane: whereas biogenic methane is associated with a range of $\delta^{13} \mathrm{C}$ from -110 to $-55 \%$ o and $\delta D$ from -400 to $-150 \%$, thermogenic methane ranges in $\delta^{13} \mathrm{C}$ from -50 to $-20 \%$ and in $\delta D$ from -275 to $-100 \%$ o. Therefore, identification of, for example, a thermogenic carbon isotopic signature in the shallow subsurface is strong evidence that methane migration from the deep subsurface has occurred (Figure 1).

Oxidation of methane also occurs in the subsurface, under both oxic and anoxic conditions. The terminal electron acceptors for anaerobic oxidation of methane (AOM) are $\mathrm{NO}_{2}{ }^{-}, \mathrm{NO}_{3}{ }^{-}, \mathrm{MnO}_{2}, \mathrm{Fe}\left(\mathrm{OH}_{3}\right)$ and $\mathrm{SO}_{4}{ }^{2-}$, in order of decreasing energy yield (Cui et al., 2015). In spite of its lower energy yield, sulphate mediated AOM is most commonly described in groundwater (e.g. Timmers et al., 2016; Van Stempvoort et al., 2005; Wolfe and Wilkin, 2017). As the microbes that are involved in methane oxidation preferentially consume the lighter isotopes, the residual, non-oxidized methane becomes enriched in both carbon and hydrogen isotopic composition (Alperin et al., 1988). This can lead to carbon or hydrogen isotope ratios that are normally associated with thermogenic methane (Figure 1). Furthermore, the oxidation of methane tends to occur at a more rapid rate than oxidation of larger alkanes, lowering the $C_{1} /\left(C_{2}+C_{3}\right)$ ratio (Whiticar, 1999). Hence, while the molecular and isotopic composition of methane formed for a given methanogenic process is quite well constrained, its subsequent alteration and migration can make 'fingerprinting' of methane origin challenging in real-world settings. 


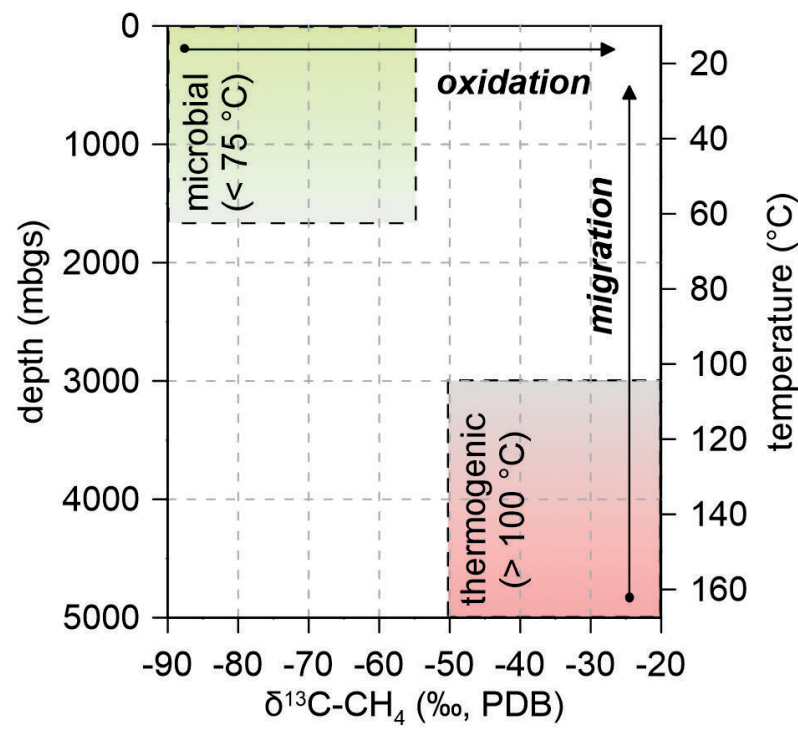

Figure 1 | Depth of formation and carbon isotopic composition of biogenic and thermogenic methane according to classically adopted ranges outlined in section 1.2. A thermal gradient of $30^{\circ} \mathrm{C} / \mathrm{km}$ that is typical for the Netherlands is assumed. Also shown are the possible shifts in depth due to migration and carbon isotope ratio due to oxidation, that can lead to difficulties in fingerprinting of methane origin in shallow groundwater.

\section{3 | CONSTRUCTION AND ABANDONMENT OF OIL AND GAS WELLS}

To construct oil and gas wells, cylindrical holes are drilled down to several kilometres into the subsurface that can be vertical, deviated and horizontal at depth and are completed with steel tubes held in place with cement. Although the manner in which this is done is rather universal, the description that follows is based on construction practices for Dutch gas wells as per publicly available well descriptions of the online Dutch Oil and Gas Portal (NLOG, 2018). Usually, a wide diameter conductor casing (e.g. 16" or 26") is driven into the ground prior to drilling to avoid collapse of surficial unconsolidated sediments into the wellbore, allow for circulation of drilling fluids, and protect the shallow soil and groundwater system (Figure 2). During drilling, pressure control in the borehole is managed by changing the density of the drilling fluid, which acts as a counterweight to the upward force exerted by formation liquids and gas pressures. The borehole is normally drilled to the target depth in a number of stages, each with a smaller drill bit resulting in a telescopic design. At the end of each stage, the drill bit and drill string are removed so that a steel casing can be placed inside the hole that isolates the wellbore from its surrounding environment. Casings consist of a series of smaller tubes that are iteratively connected to one another and lowered deeper into the borehole. When lowering the casing into the hole a 'cement shoe' is attached at the end of the first tube. Once the entire casing is placed, the cement shoe at the bottom of the hole allows for bottom-up injection of cement into the annulus between the casing and the surrounding borehole wall. As the cement solidifies the casing is set into place, providing further isolation of the wellbore from its surrounding and zonal isolation of fluids contained by the various geological formations that are penetrated. 
After the conductor casing, the next largest casing section is referred to as the surface casing. The base of the surface casing is typically set below the depth of the surficial freshwater aquifers to prevent contamination and provide the structural integrity required to drill and complete subsequent well sections. For this reason, surface casings in the Netherlands are commonly several hundred meters in length. A blowout preventer (BOP) is normally attached to the surface casing string at the surface. The BOP can let suddenly encountered overpressures dissipate by allowing liquids to escape the wellbore in a controlled manner or even close off the borehole entirely, without having to remove the drill string. Any casing section that is placed after the surface casing and before the final casing that is set in the reservoir may be referred to as an intermediate casing. Intermediate casings are placed for a number of reasons, such as preventing caving of weak formations and protection against abnormally pressured formations. To save on material quantities used and associated costs, casing sections after the surface casing can also be hung from the bottom of the previous casing using a liner configuration (Figure 2 ) and are then referred to as liners.

Finally, perforations are shot through the casing and cement at the reservoir depth. In the case of shale gas wells, hydraulic fracturing is carried out at this stage of the drilling and completion process to increase the permeability and productivity of the reservoir. It should be noted that shale gas wells are drilled horizontally at the reservoir depth to increase the contact area of perforated section with the reservoir and thereby increase gas production. Hydrocarbons are brought to the surface using a production tubing that is suspended inside the final casing section using a production packer (Figure 2). Alternatively, production may also take place directly through the final casing section itself. This is referred to as a cemented completion, as the production tubing is cemented into place. Typically, the final casing may vary from around 3 " in the case of a cemented completion to, for example, 5 " or 7" when the production tubing is suspended inside the final casing. Theoretically, these well designs allow for both production from (e.g. oil or gas) and injection into (e.g. water or fracking fluids) the target depth intervals, while preventing contamination of groundwater closer to the surface and atmospheric emissions.

When there is no further use for a deep well, usually once there are no more economically interesting hydrocarbon accumulations, it has to decommissioned. The aim of decommissioning is to sustainably restore the geological barriers that prevent vertical fluid flow, for both environmental and safety reasons, such that it can be permanently abandoned. This is achieved by placing a number of cement plugs in the wellbore to isolate the reservoir and other permeable formations. Hence, this process is also referred to as plugging and abandonment (P\&A). Decommissioning practices that are described here are for onshore wells and follow from the Dutch Mining Decree (NOGEPA, 2019). However, specifics of decomissioning practices can be different in other oil and gas jurisdictions. For example, the prescribed minimum vertical length of cement plugs can vary considerably between different countries, and was found to be generally larger in European countries than in nonEuropean countries (Van Der Kuip et al., 2011). 


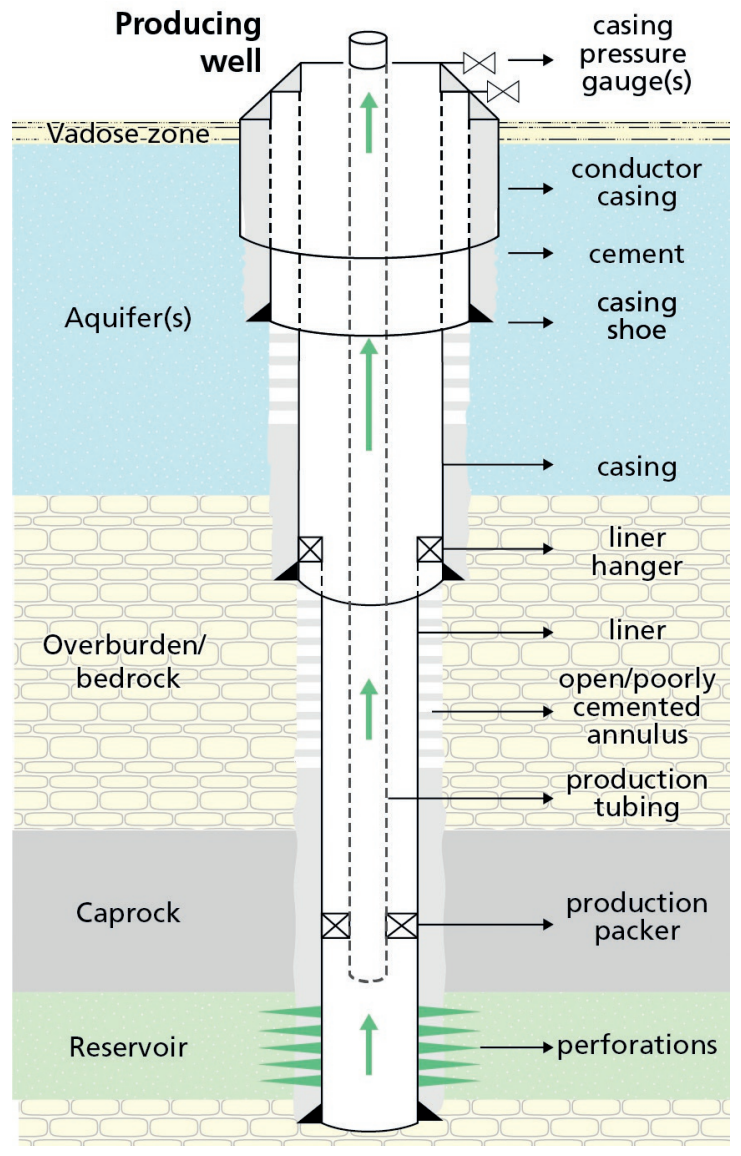

Figure 2 | Typical design and features of an onshore gas well in the Netherlands. The example shows a well that has outer annuli that were not entirely cemented to the surface, which can be the case for older wells.

Effective plugging starts by identifying all zones with flow potential (above the reservoir). Identification of these zones can be based on a number of observations including drilling records, borehole logs, and casing pressures. The deepest plug is normally set in the caprock directly above the reservoir. Then, for each zone with flow potential, an overlying sealing stratum needs to be located that has sufficient thickness and strength to withstand the maximum anticipated pressure that can develop below the plug once it is placed. In some cases, one plug may be used to seal off multiple nearby zones with flow potential. In the Netherlands, cement plugs must have a minimum vertical length of $100 \mathrm{~m}$. If a mechanical bridge plug is placed first on which the cement plugs rest (Figure 3), plugs only need to be $50 \mathrm{~m}$ long (Van Der Kuip et al., 2011).

The entire lateral interval between either sides of the borehole at the depth where a cement plug is set must be completely filled with cement, although the steel/casing. This is referred to as 'rock-to-rock' (NOGEPA, 2019). Prior to plugging, cement quality in an annular space can be checked by performing an acoustic log. If cement is absent or of insufficient quality in the annular space where a plug is to be placed, there are a number of methods to 
ensure that the seal is rock-to-rock. For example, the casing may be perforated and cement injected into the annular space (a squeeze job). If this is not possible, a casing section may need to be cut and removed or can be milled out, after which the cement is placed across the interval. Once the cement has hardened, the integrity of the plug should be verified. This is done by either a weight test, where the drill string is used to exert a force on the top of the plug, or a pressure test, where the entire casing is pressurized to check for leakage. The final plug is placed at the top of the well and is called the environmental barrier (Figure 3). The last step in the decommissioning process is to cut the well to at minimum $3 \mathrm{~m}$ below ground surface ( $6 \mathrm{~m}$ below the seafloor for offshore wells), and place a steel plate on top of the well that covers all casing sections. The land can then be restored to its original state. No post abandonment monitoring of oil and gas wells is prescribed by the Dutch mining law (Juez-Larré et al., 2018).

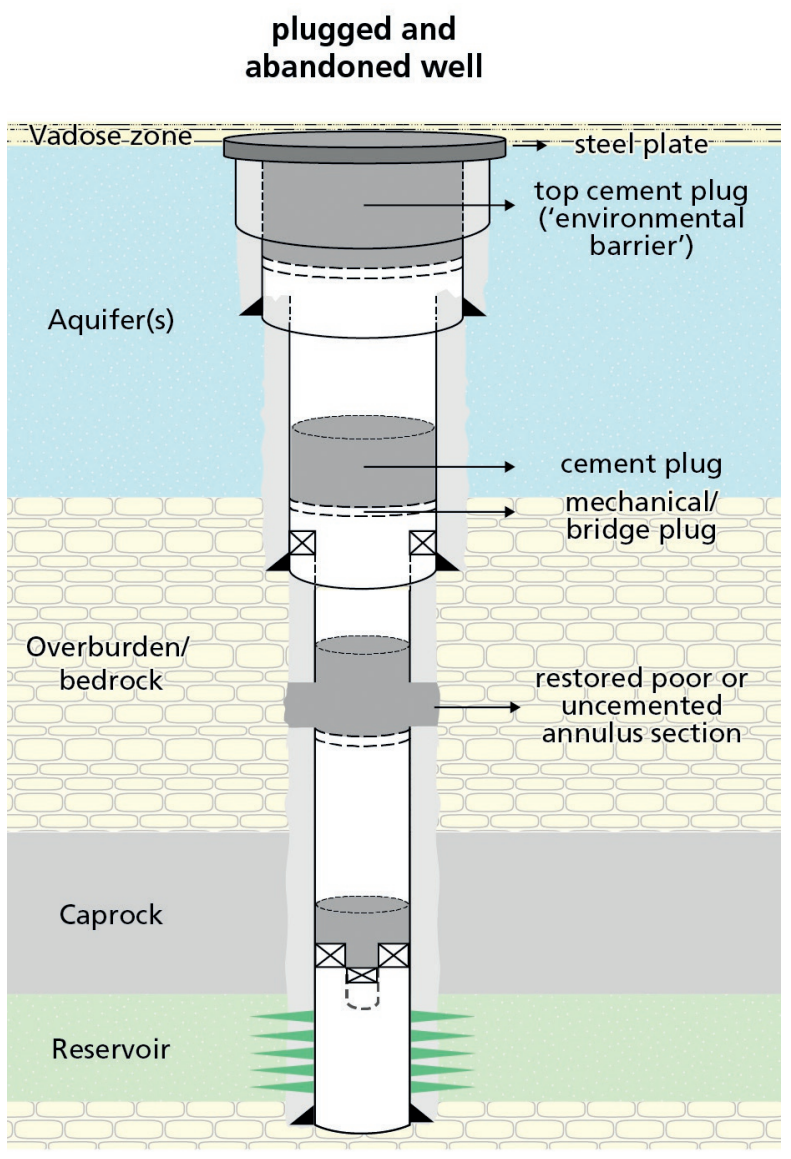

Figure 3 | Typical design and features of an onshore Dutch gas well postdecomissioning. 


\section{4 | WELL FAILURE AND METHANE LEAKAGE}

Although oil and gas wells are designed to prevent unintended migration of gas, doing so effectively and durably remains challenging (Brufatto et al., 2003). There are multiple ways in which parts of the wellbore system may fail (Figure 4). When a single element of the well is compromised, this is referred to as well barrier failure. However, for leakage to shallow groundwater or the atmosphere to occur, the failure of multiple barriers is commonly required that together form a leakage pathway from the gas bearing zone. The presence of such a leakage pathway means well integrity failure has occurred (Davies et al., 2014). When leaking gas migrates up through the annular space and reaches the wellhead, it may either collect below a sealed valve and build up pressure referred to as sustained casing pressure (SCP), or may be allowed to vent to the atmosphere which is referred to as surface casing vent flow (SCVF). Besides measurements of SCP and SCVF, leakage can sometimes be identified through visual observations of gas bubbles in flooded well cellars. The aforementioned methods of detecting and measuring leakage are not possible at decommissioned wells without an intact wellhead and particularly at cut-and-buried wells. In such cases, the detection of well integrity failure is more challenging and requires alternative methods such as soil gas flux measurements above abandoned wells (e.g. Kang et al., 2014) or measurements of dissolved methane concentrations in nearby groundwater wells (e.g. Van Stempvoort and Jaworski, 1995).

The literature on the frequency of well leakage shows that the incidence rate of methane leakage varies greatly between at oil and gas plays worldwide (Davies et al., 2014). This observed variability has been related to a number of well attributes, including differences in well type (conventional versus unconventional), geographic location, well age (Ingraffea et al., 2014), well depth (Watson and Bachu, 2009), and plugging status (Kang et al., 2016). Well age may be of particular importance, as the regulations and associated practices of well completion and plugging have become more stringent with time (Brufatto et al., 2003). For example, older abandoned wells were sometimes left unplugged during abandoned (Kang et al., 2016). Older wells were also regularly completed with long uncemented sections (Figure 2), which increases the risk of gas migration (Dusseault and Jackson, 2014). 


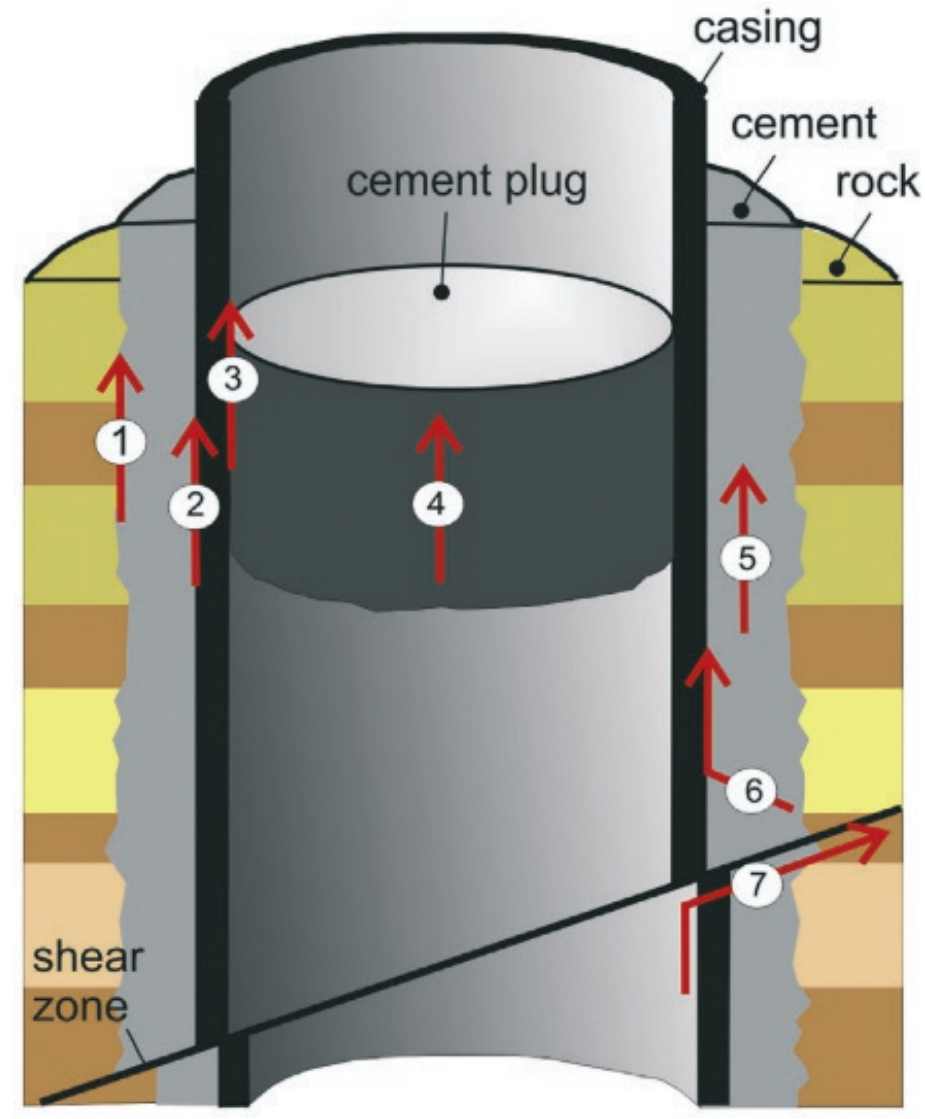

Figure 4 | Potential leakage pathways through an oil and gas wellbore.

(1) between the annular cement and borehole wall, (2) between the casing and annular cement, (3) between the casing and the plug, (4) through the plug, (5) through the annular cement, (6) from outside the wellbore though the annular cement and then between the casing and annular cement, (7) along a sheared wellbore. From Davies et al. (2014).

\section{5 | HISTORY OF OIL AND GAS PRODUCTION IN THE NETHERLANDS}

The discovery of oil in the subsurface near the village of Schoonebeek in 1944 marked the start of the economic production of hydrocarbons in the Netherlands. The first gas accumulation was discovered only 4 years layer in the nearby village of Coevorden. In 1959, the Groningen field was discovered (Figure 5). This turned out to be a historic find for the country as a whole, as the Groningen field (also known as the Slochteren field, after the village where the discovery borehole was drilled) was the largest known gas reservoir in the world when it was discovered. Nowadays, the initial recoverable gas reserves are set at 2900 billion $\mathrm{m}^{3}$ (BCM) of gas (De Jager and Visser, 2017). The returns from the Groningen field enabled a thorough exploration effort throughout the country that also led to the first off-shore natural gas drilling in the North Sea in 1970, and resulted in a highly developed gas infrastructure. These developments made the Netherlands one of the major players in the European gas market (Bergen et al., 2013).

In total, an estimated 3933 oil and gas wells have been drilled in the country, of which 2504 onshore. A peak in drilling of onshore wells of around 100 per year was reached in the early 
1980s. The amount of wells spudded each year decreased gradually since then because of the decreasing amount of potential oil and gas plays, economic factors, and growing public resistance to oil and gas development (Juez-Larré et al., 2018). Public resistance was primarily fed by induced seismicity in the Groningen area caused by depletion of the Groningen field. Since 2003, the number and magnitude of seismic events recorded here increased strongly, which has resulted in significant damages to the buildings in the area (van Thienen-Visser and Breunese, 2015). In October 2015, the Dutch government took action by capping production from the Groningen field at 27 BCM per year, down from a production of 42.5 BCM/year in 2014. Ongoing earthquakes in the years following this decision led to incrementally lower caps, with a 12 BCM production limit foreseen for October 2022 at the latest. The current aim is to stop production from the field entirely by 2030, with an estimated 600 BCM or roughly $20 \%$ of gas left in place (van den Beukel and van Geuns, 2019). Currently, only 499 of the 2504 onshore hydrocarbon wells in the Netherlands are still marked as active/producing. The other wells are marked as 'abandoned' (1303), 'plugged' (144), 'closed-in' (298) or other/ undefined (260). However, as these classifications are not clearly defined there is considerable uncertainty with regard to these numbers (Juez-Larré et al., 2018).

Following the successful development of unconventional shale plays in the US, the potential for development of shale plays in the Netherlands came under investigation. Two extensive shale formations have been identified that potentially hold economic quantities of technically producible gas: the Jurassic Posidonia Shale Formation and the Geverik Shale Member of the Carboniferous Epen Formation (Figure 5). Exploration licenses were granted to a number of oil and gas companies that were, given the geological conditions in those areas, likely aimed at shale gas exploration (Bergen et al., 2013). However, environmental concerns led to considerable societal protest, and the Dutch government decided to put a 5-year moratorium on shale gas exploration in July 2015 (Rijksoverheid, 2015). Environmental concerns were deemed sufficient to exclude shale gas production as an option for the Netherlands entirely in February 2018 (MIE and MIAC, 2018). 


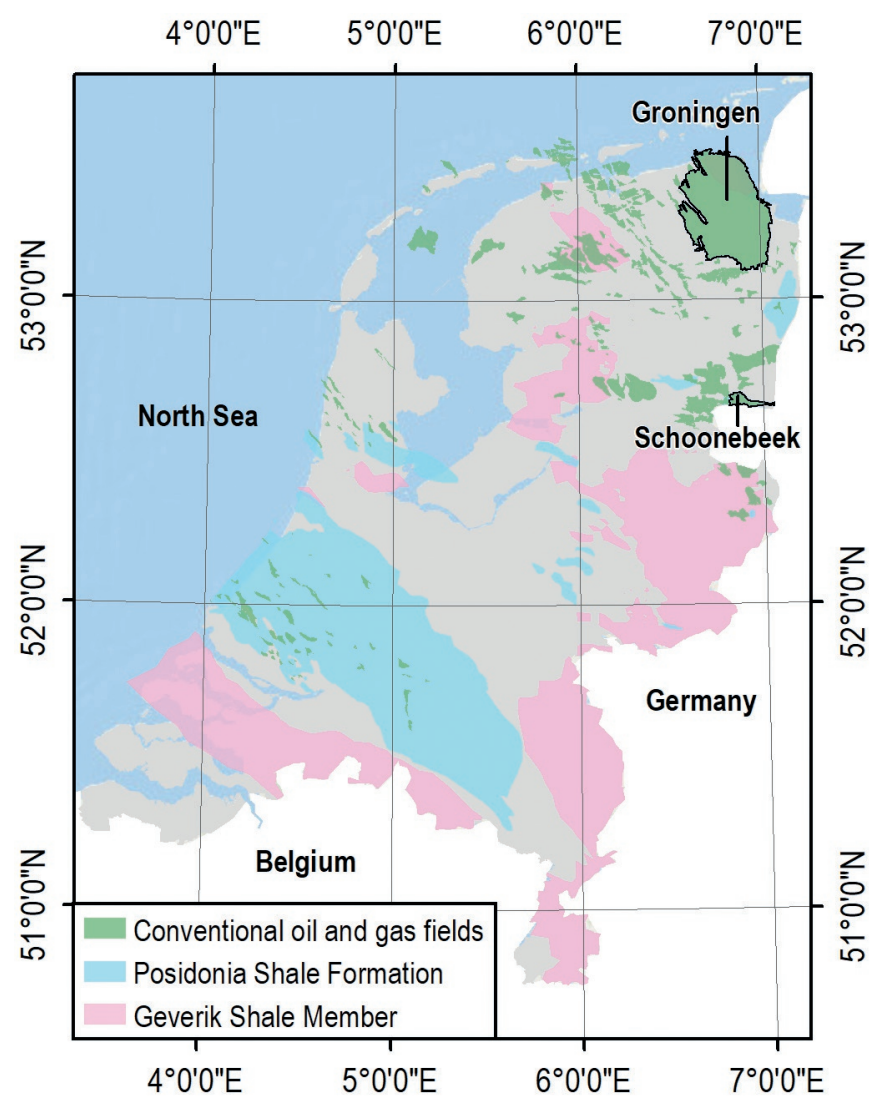

Figure 5 | Map of the Netherlands with onshore conventional hydrocarbon reservoirs and the two shale formations that were eyed for potential unconventional gas production. The two most notable conventional reservoirs, the Groningen gas field and Schoonebeek oil field, are highlighted.

\section{6 | NWO SHALE GAS AND WATER RESEARCH PROGRAM}

In light of the societal and academic concerns about the environmental impact of shale gas production, particularly concerning potential contamination of groundwater resources, a collaborative research program titled 'Shale gas and Water' was initiated by the Utrecht University, Wageniningen University and KWR Water Research (KWR). The research was funded by Dutch Research Council (NWO) together with the Dutch drinking water companies Oasen, Brabant Water and the Watermaatschappij Limburg (WML). It was divided into four sub projects:

(1) water use and geochemical vulnerability of the groundwater sources,

(2) quality of the water discharged after fracking and production, and risk assessment,

(3) treatment of discharged water,

(4) regulation and governance. 
The results presented in this thesis belong to the first sub project. Shortly after the start of the research program exploration and development of shale resources was banned throughout the Netherlands, as described in the previous section. Therefore, it was decided that the scope of this research could be shifted to include environmental concerns of conventional oil and gas production in the Netherlands. At the time, the potential impact of conventional oil and gas production on water resources had received little attention and almost no data on the integrity status of Dutch conventional hydrocarbon wells was publicly available. The exception was an assessment carried out under the auspices of the State Supervision of Mines (SodM) in 2011, which uncovered well barrier failure in 1 out of 26 production wells and 3 out of 5 produced water re-injection wells (Vignes, 2011).

\section{7 | RESEARCH AIMS AND THESIS OUTLINE}

As discussed, methane leakage from the deep subsurface may lead to groundwater quality deterioration, form an explosion hazard, and contribute to greenhouse gas emissions. Specifically, leakage resulting from deep subsurface utilization (i.e. oil and gas development) has become a topic of concern in recent years following the shale gas boom in the US, which was made possible by drilling large numbers of new onshore oil and gas wells (Jackson et al., 2014). Methane leakage caused by well integrity failure is a risk at each such well. However, observed well integrity failure rates vary widely and can thus be poorly transferred to other oil and gas plays worldwide (Davies et al., 2014). Furthermore, detection of methane leakage caused by well integrity failure may be challenging, particularly at decommissioned wells, and the true leakage rate may therefore be underestimated (Dusseault and Jackson, 2014). Methane that is naturally present in shallow groundwater, whether from deep or shallow sources, can also hinder effective detection. Therefore, there is a need to further constrain sources of methane in the shallow subsurface of oil and gas basins world-wide, and the occurrence of methane leakage caused by anthropogenic activities.

In the Netherlands, which has a long history of oil and gas production and a large proportion of hydrocarbon wells that have already been abandoned, little research has been done to investigate the occurrence of methane leakage, and its consequences for the environment and safety. Furthermore, it is unknown whether natural connections between the deep and shallow subsurface exists and whether these connections contribute to observed methane concentrations in shallow groundwater. The general aims of this research were therefore to advance understanding of the controls on methane occurrence in the Dutch groundwater and assess the impact of methane leakage on groundwater chemistry. Specifically, the objectives were to assess:

(1) the origin and distribution of methane in Dutch groundwater, and the presence of natural connections for methane migration from the deep to the shallow subsurface (chapter 2) 
(2) the occurrence of methane leakage at cut and buried abandoned gas wells in the Netherlands, and how leakage from such wells can be detected and quantified (chapter 3)

(3) the effect of long term methane leakage resulting from a historic blow-out event on the chemistry of a shallow groundwater system, including the role of anaerobic methane oxidation on the attenuation of dissolved methane (chapter 4)

(4) the retention of methane migrating through groundwater aquifers with lateral groundwater flow, and its consequence for the detectability of methane leakage (chapter 5)

Table 1 | Schematic overview of the topic, methodologies, scale and investigated zone of the chapters in this thesis.

\begin{tabular}{|c|c|c|c|c|c|c|c|}
\hline \multirow{2}{*}{ Chapter } & \multirow{2}{*}{ Topic } & \multicolumn{2}{|c|}{ Method } & \multicolumn{2}{|c|}{ Scale } & \multicolumn{2}{|c|}{ Zone } \\
\hline & & Geochemical & Modelling & National & Local & Groundwater & Unsaturated \\
\hline 2 & $\begin{array}{l}\text { Methane baseline } \\
\text { Netherlands }\end{array}$ & $\checkmark$ & & $\checkmark$ & & $\checkmark$ & \\
\hline 3 & $\begin{array}{l}\text { Leakage cut and } \\
\text { buried gas wells }\end{array}$ & $\checkmark$ & & $\checkmark$ & $\checkmark$ & & $\checkmark$ \\
\hline 4 & $\begin{array}{l}\text { Long-term effects } \\
\text { blowout Sleen (1965) }\end{array}$ & $\checkmark$ & & & $\checkmark$ & $\checkmark$ & \\
\hline 5 & $\begin{array}{l}\mathrm{CH}_{4} \text { migration in } \\
\text { unconsolidated } \\
\text { aquifers }\end{array}$ & & $\checkmark$ & & $\checkmark$ & $\checkmark$ & \\
\hline
\end{tabular}

The methodologies used for this research include both field-based and numerical studies across a variety of scales, ranging from the national scale to that of a single hydrocarbon well site. Field based methods included groundwater sampling, and soil gas sampling and flux measurements. The chemical composition of collected samples was then determined, with a focus on the molecular and isotopic composition of dissolved gasses. A schematic overview of the topic, scale, and methodologies used in each chapter is given in Table 1. In chapter 2, a datamined dataset of more than 12,000 groundwater samples with methane concentrations was assessed to examine the distribution of methane concentrations in Dutch groundwater. Additionally, targeted samples were collected and analysed for their chemical and isotopic composition from: (1) shallow aquifers where leakage of methane through natural connections was deemed most likely, (2) deep aquifers below the hydrogeological base in the country but above the depth of oil and gas accumulations, and (3) geothermal wells. In chapter 3, soil gas methane concentrations and fluxes were measured above 29 cut and buried, abandoned oil and gas wells. A well that was determined to be leaking was then subjected to a more detailed investigation by carrying out soil gas flux measurements 
in grid-like fashion above the well and in the subsoil to a depth of 2 meter below ground surface. In chapter 4 , the chemistry and dissolved gas molecular and isotopic composition of groundwater at the site of a historic gas well blowout that occurred in 1965 was analysed to determine its present day impact on the groundwater composition. Lastly, in chapter 5, a two-phase and two-component $\left(\mathrm{CH}_{4}\right.$ and $\left.\mathrm{H}_{2} \mathrm{O}\right)$ numerical model of methane migration was constructed in DuMu$u^{\mathrm{x}}$. The factors controlling migration were assessed across a range of hydrogeological conditions representative of shallow unconsolidated aquifers, with a focus on the effect of lateral groundwater flow. The possible impact of lithological layering was explored by simulation of 2 case studies based on the hydrogeological conditions encountered at the methane leakage sites uncovered in the previous chapters. 


\section{REFERENCES}

Alperin, M.J., Reeburgh, W.S., Whiticar, M.J., 1988. Carbon and hydrogen isotope fractionation resulting from anaerobic methane oxidation. Global Biogeochem. Cycles 2, 279-288. https://doi. org/10.1029/GB002i003p00279

Appelo, C.A.J., Postma, D., Postma, D., 2004. Geochemistry, Groundwater and Pollution. CRC Press. https://doi.org/10.1201/9781439833544

Bergen, F. van, Zijp, M., Nelskamp, S., Kombrink, H., 2013. Shale gas evaluation of the Early Jurassic Posidonia Shale Formation and the Carboniferous Epen Formation in the Netherlands, in: Chatellier, J., Jarvie, D. (Eds.), Critical Assessment of Shale Resource Plays: AAPG Memoir 103, Critical Assessment of Shale Resource Plays. AAPG Memoir 103, p. 24. https://doi. org/10.1306/134017221H53468

Brufatto, C., Cochran Aberdeen, J., Lee Conn David Power, S., Zaki Abd Alla El-Zeghaty, S., Fraboulet, B., Griffin, T., James Trevor Munk, S., Justus Santa Cruz, F., Joseph Levine, B.R., Montgomery, C., Murphy, D., Pfeiffer Houston, J., Tiraputra Pornpoch, T., Rishmani Abu Dhabi, L., 2003. From Mud to Cement - Building Gas Wells. Oilf. Rev. 62-76.

Clayton, C., 1991. Carbon isotope fractionation during natural gas generation from kerogen. Mar. Pet. Geol. 8, 232-240. https://doi.org/10.1016/0264-8172(91)90010-X

Cui, M., Ma, A., Qi, H., Zhuang, X., Zhuang, G., 2015. Anaerobic oxidation of methane: An "active" microbial process. Microbiologyopen 4, 1-11. https://doi.org/10.1002/mbo3.232

Darrah, T.H., Vengosh, A., Jackson, R.B., Warner, N.R., Poreda, R.J., 2014. Noble gases identify the mechanisms of fugitive gas contamination in drinking-water wells overlying the Marcellus and Barnett Shales. Proc. Natl. Acad. Sci. 111, 14076-14081. https://doi.org/10.1073/ pnas. 1322107111

Davies, R.J., Almond, S., Ward, R.S., Jackson, R.B., Adams, C., Worrall, F., Herringshaw, L.G., Gluyas, J.G., Whitehead, M.A., 2014. Oil and gas wells and their integrity: Implications for shale and unconventional resource exploitation. Mar. Pet. Geol. 56, 239-254. https://doi.org/10.1016/j. marpetgeo.2014.03.001

Davies, R.J., Mathias, S.A., Moss, J., Hustoft, S., Newport, L., 2012. Hydraulic fractures: How far can they go? Mar. Pet. Geol. 37, 1-6.

De Jager, J., Visser, C., 2017. Geology of the Groningen field - An overview. Geol. en Mijnbouw/ Netherlands J. Geosci. 96, s3-s15. https://doi.org/10.1017/njg.2017.22

Dusseault, M., Jackson, R., 2014. Seepage pathway assessment for natural gas to shallow groundwater during well stimulation, in production, and after abandonment. Environ. Geosci. 21, 107-126. https://doi.org/10.1306/eg.04231414004

Erno, B., Schmitz, R., 1996. Measurements of Soil Gas Migration Around Oil And Gas Wells In the Lloydminster Area. J. Can. Pet. Technol. 35, 37-46. https://doi.org/10.2118/96-07-05

Etiope, G., Feyzullayev, A., Baciu, C.L., 2009. Terrestrial methane seeps and mud volcanoes: A global perspective of gas origin. Mar. Pet. Geol. 26, 333-344.

Harrison, S.S., 1983. Evaluating System for Ground-Water Contamination Hazards Due to Gas-Well Drilling on the Glaciated Appalachian Plateau. Groundwater 21, 689-700. https://doi. org/10.1111/j.1745-6584.1983.tb01940.x 
Hinrichs, K.-U., Hayes, J.M., Bach, W., Spivack, A.J., Hmelo, L.R., Holm, N.G., Johnson, C.G., Sylva, S.P., 2006. Biological formation of ethane and propane in the deep marine subsurface. Proc. Natl. Acad. Sci. 103, 14684-14689. https://doi.org/10.1073/pnas.0606535103

Ingraffea, A.R., Wells, M.T., Santoro, R.L., Shonkoff, S.B.C., 2014. Assessment and risk analysis of casing and cement impairment in oil and gas wells in Pennsylvania, 2000-2012. Proc. Natl. Acad. Sci. 111, 10955-10960. https://doi.org/10.1073/pnas.1323422111

Jackson, R.B., Vengosh, A., Carey, J.W., Davies, R.J., Darrah, T.H., Sullivan, F.O., Gabrielle, P., 2014. The Environmental Costs and Benefits of Fracking. Annu. Rev. Environ. Resour. 39, 327-362. https:// doi.org/10.1146/annurev-environ-031113-144051

Jackson, R.B., Vengosh, A., Darrah, T.H., Warner, N.R., Down, A., Poreda, R.J., Osborn, S.G., Zhao, K., Karr, J.D., 2013. Increased stray gas abundance in a subset of drinking water wells near Marcellus shale gas extraction. Proc. Natl. Acad. Sci. 110, 11250-11255. https://doi.org/10.1073/ pnas. 1221635110

Juez-Larré, J., Denier van der Gon, H., Dellaert, S., Griffioen, J., Nepveu, M., Peters, R., 2018. Emissie van het broeikasgas methaan gerelateerd aan de olie- en gassector in Nederland met nadruk op exploratie en productie. Utrecht.

Kang, M., Christian, S., Celia, M.A., Mauzerall, D.L., Bill, M., Miller, A.R., Chen, Y., Conrad, M.E., Darrah, T.H., Jackson, R.B., 2016. Identification and characterization of high methane-emitting abandoned oil and gas wells. Proc. Natl. Acad. Sci. 113, 13636-13641. https://doi.org/10.1073/ pnas. 1605913113

Kang, M., Kanno, C.M., Reid, M.C., Zhang, X., Mauzerall, D.L., Celia, M.A., Chen, Y., Onstott, T.C., 2014. Direct measurements of methane emissions from abandoned oil and gas wells in Pennsylvania. Proc. Natl. Acad. Sci. 111, 18173-18177. https://doi.org/10.1073/pnas.1408315111

Kelly, W.R., Matisoff, G., Fisher, J.B., 1985. The effects of a gas well blow out on groundwater chemistry. Environ. Geol. Water Sci. 7, 205-213. https://doi.org/10.1007/BF02509921

Ministry for Infrastructure and Environment, Ministry for Econimic Affairs and Climate, 2018. Structuurvisie Ondergrond. Den Haag, Netherlands.

Miyazaki, B., 2009. Well integrity: An overlooked source of risk and liability for underground natural gas storage. Lessons learned from incidents in the USA: Figure 1. Geol. Soc. London, Spec. Publ. 313, 163-172. https://doi.org/10.1144/sp313.11

Molofsky, L.J., Connor, J. a, Farhat, S.K., Jr, A.S.W., 2011. Methane in Pennsylvania water wells unrelated to Marcellus shale fracturing. Oil Gas J. December 5, 54-67.

Molofsky, L.J., Connor, J.A., Wylie, A.S., Wagner, T., Farhat, S.K., 2013. Evaluation of Methane Sources in Groundwater in Northeastern Pennsylvania. Groundwater 51, 333-349.

Myhre, G., Shindell, D., Bréon, F.M., Collins, W., Fuglestvedt, J., Huang, J., Koch, D., Lamarque, J.F., Lee, D., Mendoza, B., T. Nakajima, A. Robock, G. Stephens, T.T. and H.Z., 2014. Anthropogenic and Natural Radiative Forcing, in: Intergovernmental Panel on Climate Change (Ed.), Climate Change 2013 - The Physical Science Basis. Cambridge University Press, Cambridge, pp. 659-740. https://doi. org/10.1017/CBO9781107415324.018

NLOG, 2018. Netherlands Oil and Gas Portal Deep Borehole Data [WWW Document]. URL https://www. nlog.nl/en/boreholes (accessed 7.6.18).

NOGEPA, 2019. Industrie standaard nr. 45. 
Osborn, S.G., Vengosh, A., Warner, N.R., Jackson, R.B., 2011. Methane contamination of drinking water accompanying gas-well drilling and hydraulic fracturing. Proc. Natl. Acad. Sci. 108, E665-E666. https://doi.org/https://doi.org/10.1073/pnas.1100682108

Rijksoverheid, 2015. No shale gas production coming five years.

Schink, B., 1997. Energetics of syntrophic cooperation in methanogenic degradation. Microbiol. Mol. Biol. Rev. 61, 262-80.

Timmers, P.H., Suarez-Zuluaga, D.A., van Rossem, M., Diender, M., Stams, A.J., Plugge, C.M., 2016. Anaerobic oxidation of methane associated with sulfate reduction in a natural freshwater gas source. ISME J. 10, 1400-1412. https://doi.org/10.1038/ismej.2015.213

van den Beukel, J., van Geuns, L., 2019. Groningen gas: the loss of a social license to operate. The Hague.

Van Der Kuip, M.D.C., Benedictus, T., Wildgust, N., Aiken, T., 2011. High-level integrity assessment of abandoned wells, in: Energy Procedia. pp. 5320-5326. https://doi.org/10.1016/j. egypro.2011.02.513

Van Stempvoort, D., Jaworski, E., 1995. Migration of Methane into Groundwater from Leaking Production Wells near Lloyd minster. Canada: Calgary.

Van Stempvoort, D., Maathuis, H., Jaworski, E., Mayer, B., Rich, K., 2005. Oxidation of fugitive methane in ground water linked to bacterial sulfate reduction. Ground Water 43, 187-199. https://doi. org/10.1111/j.1745-6584.2005.0005.x

van Thienen-Visser, K., Breunese, J.N., 2015. Induced seismicity of the Groningen gas field: History and recent developments. Lead. Edge 34, 664-671. https://doi.org/10.1190/tle34060664.1

Vidic, R.D., Brantley, S.L., Vandenbossche, J.M., Yoxtheimer, D., Abad, J.D., 2013. Impact of shale gas development on regional water quality. Science 340, 1235009. https://doi.org/10.1126/ science. 1235009

Vignes, B., 2011. Contribution to well integrity and increased focus on well barriers from a lifecycle aspect. University of Stavanger.

Watson, T.L., Bachu, S., 2009. Evaluation of the Potential for Gas and CO2 Leakage Along Wellbores. SPE Drill. Complet. 24, 115-126. https://doi.org/10.2118/106817-PA

Wei, L., Schimmelmann, A., Mastalerz, M., Lahann, R.W., Sauer, P.E., Drobniak, A., Strąpoć, D., Mango, F.D., 2018. Catalytic generation of methane at $60-100^{\circ} \mathrm{C}$ and $0.1-300 \mathrm{MPa}$ from source rocks containing kerogen Types I, II, and III. Geochim. Cosmochim. Acta 231, 88-116. https://doi. org/10.1016/j.gca.2018.04.012

Whiticar, M.J., 1999. Carbon and hydrogen isotope systematics of bacterial formation and oxidation of methane. Chem. Geol. 161, 291-314. https://doi.org/10.1016/s0009-2541(99)00092-3

Wisen, J., Chesnaux, R., Wendling, G., Werring, J., Barbecot, F., Baudron, P., 2019. Assessing the potential of cross-contamination from oil and gas hydraulic fracturing: A case study in northeastern British Columbia, Canada. J. Environ. Manage. 246, 275-282. https://doi.org/10.1016/j. jenvman.2019.05.138

Wolfe, A.L., Wilkin, R.T., 2017. Evidence of Sulfate-Dependent Anaerobic Methane Oxidation within an Area Impacted by Coalbed Methane-Related Gas Migration. Environ. Sci. Technol. 51, 19011909. https://doi.org/10.1021/acs.est.6b03709 


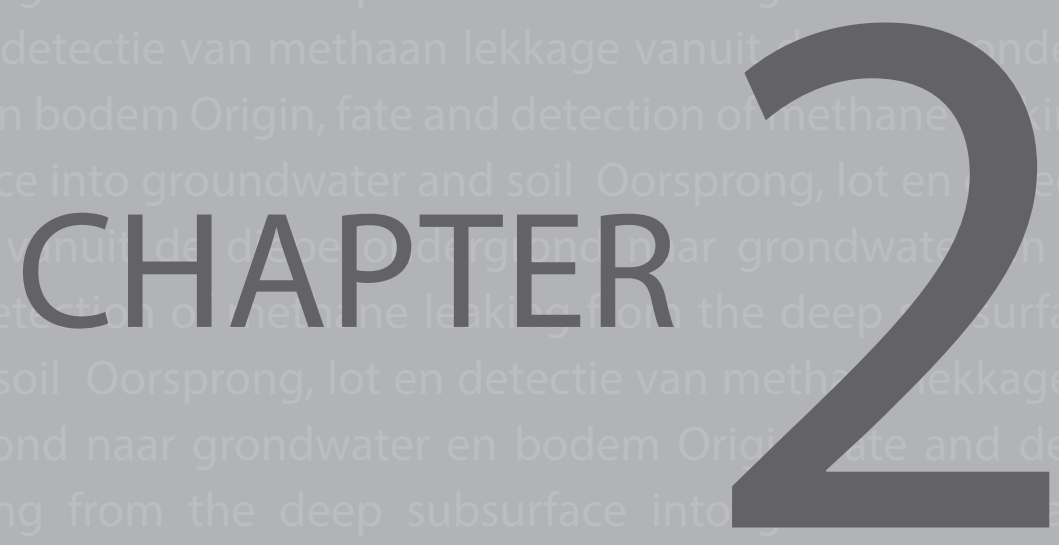

Controls on groundwater methane occurrence and origin from shallow aquifers to deep formation waters in the Netherlands 


\section{ABSTRACT}

Production of oil and gas may cause unintended connectivity between the deep and shallow subsurface, leading to groundwater contamination with methane. A baseline characterization of methane occurrence and origin in the subsurface of the Netherlands was made using a large set of methane concentrations in shallow groundwater $(n=12,219)$. Additionally, targeted sampling ( $n=40)$ was carried out in 1$)$ the shallow aquifers at locations where the presence of thermogenic methane was deemed most probable, such as above faults and known gas reservoirs, 2) deep groundwater aquifers below the depth of Neogene and Paleogene marine clays that form the hydrogeological base in the country and (3) geothermal formation waters at 1640 - $2625 \mathrm{~m}$ depth. Median methane concentrations in shallow aquifers are relatively high in the international context $\left(0.2 \mathrm{mg} \cdot \mathrm{L}^{-1}\right)$. The highest methane concentrations (up to $120 \mathrm{mg} . \mathrm{L}^{-1}$ ) are likely linked to reactive organic matter in Holocene deposits and Pleistocene marine and glacial formations. Intermediate values are found at depth (100 - $160 \mathrm{~m}$ bgs) in Pleistocene aquifers in the eastern and southern inland areas of the Netherlands. Isotopic evidence and gas composition of naturally occurring methane indicates that methane in the targeted samples from shallow aquifers was of biogenic origin, and that methanogenesis predominantly occurs via $\mathrm{CO}_{2}$ reduction. Only trace amounts of methane $\left(<0.2 \mathrm{mg} \cdot \mathrm{L}^{-1}\right)$ were observed in the deep groundwater aquifers. A combination of methane and ethane isotopic composition showed that this methane consists of varying fractions of both biogenic and thermogenic origin. Methane in the geothermal reservoirs has an oil associated thermogenic origin. Overall, these findings highlight that future observations of thermogenic methane in Dutch shallow groundwater (post-Paleogene) are most probably linked to anthropogenic activities in the deep subsurface. 


\section{1 | INTRODUCTION}

Research on the subsurface occurrence and chemistry of methane has gained increasing prominence in recent years, given that it is a strong greenhouse gas with rapidly growing atmospheric concentrations (Nisbet et al., 2019), its introduction in fresh groundwater can adversely affect water quality (Rice et al., 2018), and it can constitute an explosion and asphyxiation hazard when accumulating in confined spaces (Williams and Aitkenhead, 1991). Notably, the massive scale production of oil and gas from shale formations in the US, enabled by the application of horizontal drilling and hydraulic fracturing techniques, has raised concerns about the contribution of anthropogenic methane leakage from the deep subsurface to these hazards (Jackson et al., 2014). Leakage of methane through impaired wellbore systems into shallow aquifers and the atmosphere has indeed been shown to locally contribute significantly to greenhouse gas emissions (Kang et al., 2014), lead to undesirable changes in groundwater quality (Forde et al., 2019), and in rare cases cause explosions (Miyazaki, 2009). Furthermore, evidence of stray gas migration originating in the deep subsurface could be a precursor for leakage of more hazardous fluids, such as brines or fluids involved in the drilling and production process (Vengosh et al., 2014).

As a consequence, groundwater methane concentrations and isotopic composition have increasingly been used to look for anthropogenic connections between shallow aquifers and deeper geological formations. However, methane in groundwater may also occur naturally as the result of either local microbial methanogenesis, leakage of gaseous methane through natural methane seeps and mud volcanoes (Etiope et al., 2009), or mixing with deeper, methane containing, groundwater (Warner et al., 2012). Distinguishing between these multiple possible origins of methane and attributing either a natural or anthropogenic source can be challenging. Therefore, determining the pristine, pre-drilling, methane baselines in groundwater can be vital to avoid later conflicts. Indeed, a number of studies carried out in US states overlying the Marcellus shale play came to conflicting conclusions: while some studies contributed elevated methane concentrations to their proximity to shale gas wells (Jackson et al., 2013; Osborn et al., 2011), others concluded that topographic location played a more important role in determining their distribution (Molofsky et al., 2013, 2011; Siegel et al., 2015).

In the shallow groundwater system of the Netherlands, which typically consists of Quaternary sandy aquifers down to depths of around $400 \mathrm{~m}$, the presence of dissolved methane is ubiquitous and is hypothesized to have a local microbial (i.e. 'biogenic') origin (Stuyfzand et al., 1994). A dataset analysed by Fortuin and Willemsen (2005) showed that methane concentrations close to solubility are found near the surface $(<20 \mathrm{mbgs})$ and the part of the country where reactive peat layers occur at shallow depth. The fact that large amounts of methane can be found in the shallow subsurface has been known for centuries however, as reports of gaseous, flammable, blowouts encountered during drilling of shallow water wells go as far back as the $18^{\text {th }}$ century. From the end of the $19^{\text {th }}$ century to midway through the $20^{\text {th }}$ century, gas accumulations that formed below shallow clay deposits were 
even exploited for private use at farms in the coastal provinces, by extracting groundwater and allowing the degassing methane to accumulate below a suspended kettle balanced by counterweights (Bol, 1991).

Methane isotopes of gas collected from two such systems indeed revealed a biogenic (microbial) origin (Buijs and Stuurman, 2003). More recently, methane in 9 groundwater wells with known high methane concentrations was found to be of biogenic origin as well, with a sample collected near the site of a catastrophic gas well blowout that occurred in 1965 in the eastern Netherlands being the exception (Cirkel et al., 2015). These findings confirm that methane in shallow groundwater of the Netherlands is predominantly of biogenic origin. However, thermogenic gas locally migrating from depth through either natural or anthropogenic conduits cannot be ruled out, given the presence of numerous oil and gas reservoirs in the deep subsurface (Figure 1). Since production of these resources started in the 1940s, a total of 2500 oil and gas wells have been drilled, of which more than 1700 onshore (NLOG, 2020). The majority of produced gas comes from the Groningen gas field, which is by far the country's largest natural gas accumulation and one of the biggest in the world. However, reservoir depletion here has led to induced seismicity with significant societal impact (van Thienen-Visser and Breunese, 2015). As a result, production of onshore natural gas and drilling of new wells has decreased rapidly in recent years. Besides these conventional reservoirs, two extensive shale formations are present (Figure 1) that are potentially economically viable (Bergen et al., 2013). However, a decree by the Dutch government has banned both shale gas exploration and production due to environmental concerns (MIE and MEAC, 2018).

In spite of the lack of production from shale plays, hydraulic fracturing has been applied to improve production in a number of 'conventional' fields. A survey commissioned by the State Supervision of Mines (SodM) tallied a total of 245 frack jobs dating back to 1954, 63 of which did not involve high pressure fluid injection but only an acid treatment (TNO, 2018). Given the depth (900 to $4000 \mathrm{~m}$ below mean sea level) nature of these frack jobs, the thickness of overlying cap rocks and the stress regime, the risk of leakage to shallow groundwater occurring through the induced fractures is low (TNO, 2018). However, migration of methane to shallow groundwater through impaired wellbores has been shown to occur. A recent survey by the SodM found some form of well barrier failure at 227 (23\%) out of 986 gas wells (SodM, 2019). Failure of a single barrier does not necessarily imply that leakage to the environment occurs, since there are typically multiple barriers in place. Nonetheless, observations of thermogenic gas bubbles in flooded well cellars showed that gas migration originating in the deep subsurface occurred at at least 13 of the surveyed gas wells (1.3\%). Well integrity failure has also been confirmed by means of gas flux measurements in the vadose zone above a cut and buried, fully decommissioned gas well (Schout et al., 2019). Lastly, migration of thermogenic gas through the fractures opened by the aforementioned blowout site is believed to be ongoing (Schout et al., 2017). 
Contrary to these anthropogenic leakages, and in spite of the presence of a number of significant faults and fractures in the country (Figure 1), no clear evidence exists of gas migration from the deep subsurface to the shallow groundwater environment through natural conduits. Fluid flow towards the shallow aquifers is assumed to be limited by a thick sequence of impermeable Neogene and Paleogene marine clays that directly underly the aquifer system in nearly the entire country (Griffioen et al., 2016). There is some evidence that local conduits for fluid flow through these barriers exist on the Dutch continental shelf in the North Sea, as methane with an apparent mixed biogenic and thermogenic origin was observed near an offshore pockmark (Schroot et al., 2005). However, the mixed isotopic signature could also be explained by oxidative fractionation of biogenic methane, and hence the evidence was inconclusive. Other observations of shallow gas encountered in the Dutch part of the North Sea were determined to be of microbial origin (Verweij et al., 2018), with the exception of one well in the northern offshore where thermogenic methane has apparently migrated in to the Quaternary deposits (Ten Veen et al., 2013). Onshore, migration of thermogenic methane through a fault to the atmosphere was observed in a former coal mining area in Germany, around $75 \mathrm{~km}$ from the border with the Netherlands. However, neither the Paleogene marine clays nor other Cenozoic unconsolidated sediments that characterize the Dutch subsurface are present at this location. Hence, gas migration was concentrated in faults penetrating the outcropping Cretaceous consolidated rocks (Thielemann et al., 2000).

Given the abundant presence of methane in shallow groundwater, the long history of oil and gas extraction, and potential for future uses of the deep subsurface, there is a clear need to further develop the groundwater methane baseline of the Netherlands. A limited number of observations suggest that shallow methane is purely of microbiological origin, and hence that findings of thermogenic methane in this groundwater compartment would indicate an anthropogenic disturbance. A thorough analysis on the controls on methane concentrations in the country is lacking. Importantly, the occurrence and origin of methane between the shallow aquifer system and the depth of the oil and gas reservoirs is unknown. In this paper, the distribution of methane concentrations in shallow groundwater was assessed using a methane concentration dataset compiled through data-mining and consisting of more than 12,000 individual samples, partly consisting of repeat samples over time in the same well screens. Furthermore, a targeted sampling campaign was conducted, analysing both groundwater below the marine clays barriers underlying the shallow aquifers and above these barriers at locations where thermogenic gas migration was deemed most likely due to presence of faults or fractures. The dissolved gas compositions are then compared to those from oil and gas wells in the country, such that the molecular and isotopic composition of (dissolved) gasses throughout the entire depth interval is analysed. 


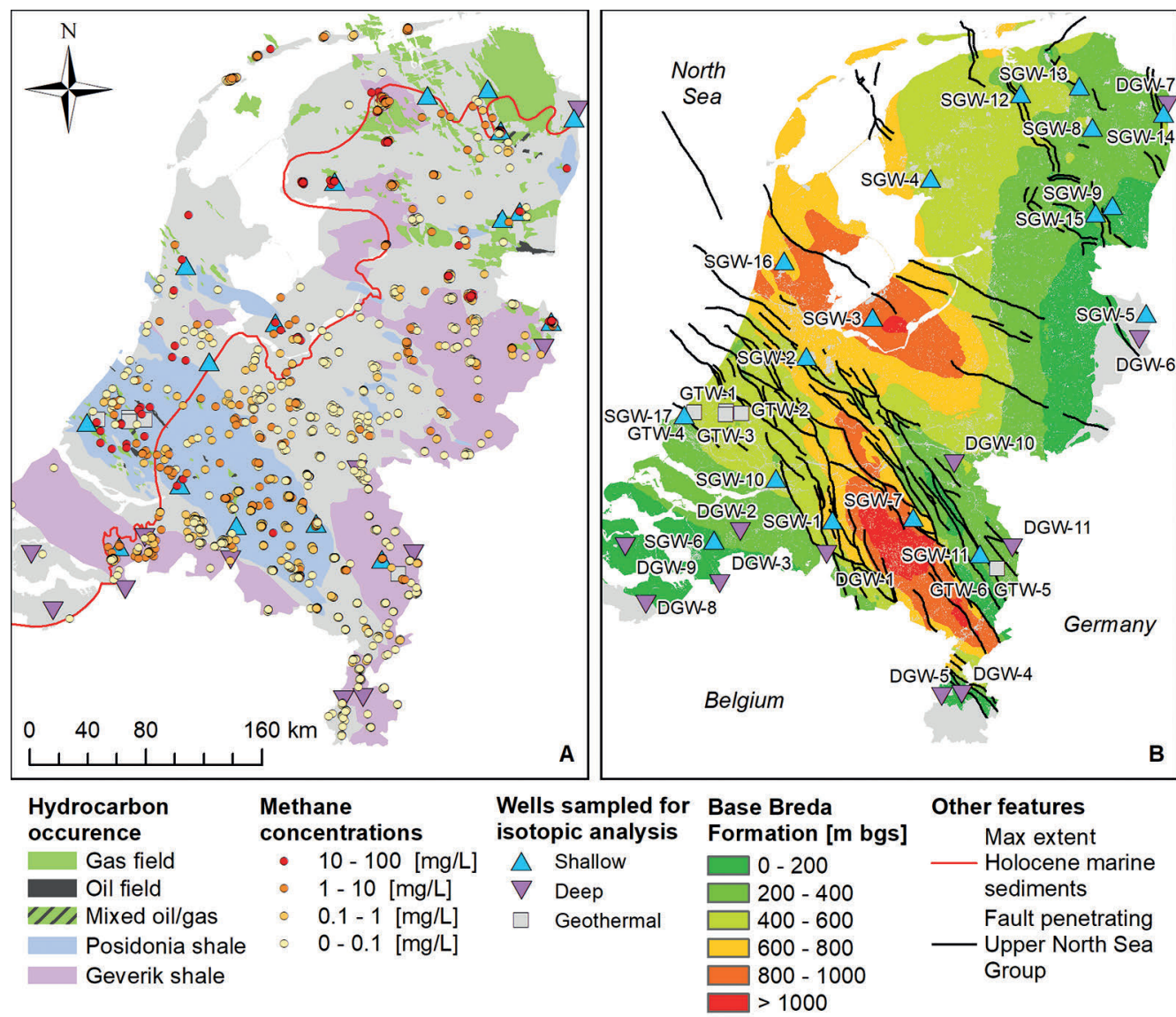

Figure 1 | Map of the Netherlands showing the onshore oil and gas fields, major shale formations, maximum extent of Holocene Marine deposits (after Griffioen et al., 2013), averaged methane concentrations per well screen in the datamined dataset $(A)$, locations of the samples collected for isotopic analysis $(A+B)$, depth to base of the Neogene Breda formation and the main faults penetrating through to the surficial geology (B). Samples labelled SGW and DGW are from shallow and deep groundwater wells, respectively, indicating whether the sampled well screens were above or below the base of the Breda Formation. Samples labelled GTW were collected from geothermal wells. Geological data retrieved from the Netherlands Oil and Gas Portal (NLOG.nl) and the data and information site of the Geological Survey of the Netherlands (www.DINOloket.nl). Area west and north of the line showing the maximum extent of Holocene marine deposits is referred to as the coastal lowlands. 


\section{2 | HYDROGEOLOGY OF THE NETHERLANDS}

\subsubsection{Quaternary and Neogene shallow groundwater system}

The Netherlands is a largely deltaic country where several major European rivers coalesce (Rhine, Meuse and Scheldt). It has a total land surface area (including inland waters) of $37,363 \mathrm{~km}^{2}$. It is located at the south-east of the subsiding North Sea sedimentary basin and neighbours Belgium and Germany on its southern and eastern border, respectively (Figure 1). The climate is temperate with an annual precipitation of around $850 \mathrm{~mm}$. The hydrogeology is determined by the presence of thick successions of Cenozoic unconsolidated sediments of dominantly marine and fluvial origin that were deposited during various stages of sea level highs and lows. At the maximum extent of the Saalian Glaciation, the northern half of the country became covered by ice. Glacial till formations were left behind in the northern half of the country and ice pushed ridges are present in the centre and east of the country that have a maximum elevation of 110 meters above sea level (masl). Sand dunes are situated along the coastline that play an important role in flood protection, and reach a maximum of around 50 masl.

During the Holocene, encroaching sea levels caused peat to form at a regional scale behind the coastal barriers. The peat area then became inundated, and clayey marine sediments were deposited in the resulting tidal lagoons. This part of the country is referred to as the coastal lowlands (Figure 1). A significant part of the Holocene coastal area is now formed by polders that are situated below sea level and are drained by a system of ditches and canals. This causes groundwater exfiltration of sometimes saline groundwater in these polders. Another part of the Holocene landscape comprises of riverine deposits. This Holocene riverine area has not been inundated by seawater. The Holocene peat and clay act as a confining layer to the underlying Pleistocene aquifers in both Holocene areas, while regional recharge occurs from the coastal dunes and ice-pushed ridges. In most of the other parts of the country the surficial geology is defined by Pleistocene fluvial sediments that form phreatic aquifers. The surficial Pleistocene sands in the Centre, East and South constitute the major groundwater recharge areas of the country (Meinardi, 1994). The most south-eastern part of the country has an entirely different geology with Cretaceous formations at shallow depth. The groundwater table is generally very shallow, with the exception of elevated areas in the south-eastern parts of the country and the ice pushed ridges in the centre and East. In these locations, the depth to groundwater can be several 10 s of meters.

The units that host active circulation of fresh groundwater are the more coarsegrained Quaternary and Neogene deposits that increase in thickness from roughly $50 \mathrm{~m}$ in the South-East to around 400 to $500 \mathrm{~m}$ in the North-West (Dufour, 1998) and are part of the Upper North Sea Group (Table 1). Here, turnover time of groundwater is in the order of days to locally more than 10,000 years (de Vries, 2007). Full stratigraphic details of recognized Cenozoic formations in the Netherlands are given in Figure S1. Notable aquifers are found in the Pleistocene fluvial deposits of the Kreftenheye, Urk, Sterksel, Waalre, Beegden, Appelscha, Peize and Kieseloolite Formations as well as the sandy units of the marine Early Pleistocene 
Maassluis Formation and the Neogene Oosterhout and Breda Formations. However, clay layers of regional significance may be present in these units. Low permeability glacial clays of the Peelo (Elsterian) and Drente (Saalian) Formations form barriers to flow in the North-East of the country. Marine clays were also deposited in glacial basins formed during the Saalian ice-age that are assigned to the Eem Formation (de Gans et al., 2000).

The Early Pleistocene and Neogene marine formations, that form the base of the Upper North Sea Group, increasingly consist of thick clay deposits with depth. In the coastal lowlands, they contain saline groundwater that has also intruded parts of overlying fluvial aquifers (de Vries, 2007), and the fresh/brackish interface varies in depth between 50 to 130 mbgs (Mendizabal et al., 2011). In the Pleistocene part of the country the fresh-salt interface is generally deeper (between 100 - 500 mbgs). However, towards the eastern border it follows the depth of the underlying Paleogene marine formations of the Middle and Lower North Sea Groups (Table 1) which can be just $10 \mathrm{~m}$ below the surface. The depth and thickness of Neogene formations, as well as the depth of the fresh-salt interface, are much greater in the Roer Valley Graben in the South of the Netherlands, which is bounded by South-East North-West running faults on either side (Figure 1). Here, rapid deposition of these formations could occur in the Cenozoic due to strong subsidence associated with rifting. Steps in hydraulic head over these faults show that they form strong barriers to horizontal groundwater flow in the shallow groundwater systems (Bense et al., 2003). Rifting during earlier geological eras associated with the same rift system accounts for the extension of these faults into the west of the Netherlands, where they may also penetrate though to the base of the Neogene Formations (Verweij et al., 2012).

\subsubsection{Paleogene and older groundwater and hydrocarbon systems}

The Paleogene formations underlying the shallow groundwater system are found in virtually the entire country and dominantly consist of low permeable clays that can be up to several 100 meters thick (Verweij et al., 2012). Notable deposits include the Rupel Clay and leper Clay Members. The former is known as the Boom Clay in Belgium where it is considered as a host rock for the permanent underground disposal of nuclear waste (Verhoef et al., 2014). However, more permeable units also exist in the Middle and Lower North Sea Groups, such as the Brussel Sand and the Basal Dongen Sand Members. Groundwater in these formations is generally saline or hypersaline, except at the borders where outcrops of these formations may lie relatively nearby (Griffioen et al., 2016). Locally, gas accumulations have been encountered in the deepest permeable Paleogene units. These have remained mostly undeveloped due to anticipated subsidence problems (Jager and Geluk, 2007). The origin of these shallow gas accumulations are subject of debate, and molecular and isotopic evidence is limited. The three available gas samples from such wells from the onshore of the Netherlands (data from NLOG, 2020) are also inconclusive as isotopic analyses were not carried out. The $C_{1} /\left(C_{2}+C_{3}\right)$ molar ratio measured for these samples ranged from 422 to 1930 (Table S1), which appears to indicate a mixed biogenic - thermogenic origin. 
An analysis of fluid pressures in the Dutch subsurface has shown that overpressured conditions, resulting from the balance between sediment loading and pressure dissipation by fluid flow, are primarily observed in the Northern Netherlands and northern offshore. Overpressured conditions are not encountered in the Southern Netherlands, which is most likely linked to aforementioned faulting in this area. Together with a gradual increase in the deposition of sediments with larger grain sizes towards the margins of the North Sea Basin (located near the Southern border of the Netherlands), these faults have likely contributed to the dissipation of overpressures by vertical fluid flow on geological time scales (Verweij et al., 2012). Prominent geological units below which overpressures have been observed are the claystones of the Lower Cretaceous Rijnland Group and the salt deposits of the Triassic Röt Formation and the Permian Zechstein Group (Table 1).

Table 1 | Simplified stratigraphic overview of the Netherlands showing the geological units relevant to this paper. The dots in columns $\mathrm{R}, \mathrm{C}$ and $\mathrm{S}$ show whether the unit typically serves as a reservoir/ aquifer (R), caprock/confining layer (C) or source rock (S). Based on Jager and Geluk, 2007. Detailed lithostratigraphy of Cenozoic formations is shown in Figure S1.

\begin{tabular}{|c|c|c|c|c|c|c|}
\hline Era & Period & Stratigraphic Group & Notable Units & $\mathbf{R}$ & C & $S$ \\
\hline \multirow{3}{*}{ 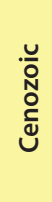 } & Quarternary & \multirow{2}{*}{$\begin{array}{l}\text { Upper North } \\
\text { Sea (NU) }\end{array}$} & Full details in Figure S1. & $\bullet$ & & \\
\hline & Neogene & & Full details in Figure S1. & $\bullet$ & & \\
\hline & Paleogene & $\begin{array}{c}\text { Middle (NM) and Lower (NL) } \\
\text { North Sea }\end{array}$ & Full details in Figure S1. & $\bullet$ & - & \\
\hline \multirow{7}{*}{$\begin{array}{l}\text { U } \\
\text { N } \\
\text { y } \\
\sum\end{array}$} & \multirow{3}{*}{ Cretaceous } & Chalk (CK) & Ommelanden Formation & $\bullet$ & & \\
\hline & & \multirow{2}{*}{ Rijnland (KN) } & Vlieland Claystone Formation & & - & \\
\hline & & & Vlieland Sandstone Formation & $\bullet$ & & \\
\hline & \multirow{2}{*}{ Jurassic } & Schieland (SL) & Delft Sandstone Member & $\bullet$ & & \\
\hline & & Altena (AT) & Posidonia Shale Formation & & & - \\
\hline & \multirow{2}{*}{ Trassic } & Upper Germanic Trias (RN) & Röt Formation & & $\bullet$ & \\
\hline & & Lower Germanic Trias (RB) & Main Bundsandstein Subgroup & $\bullet$ & & \\
\hline \multirow{5}{*}{$\begin{array}{l}\frac{U}{O N} \\
\frac{N}{d} \\
\frac{d}{0}\end{array}$} & \multirow{2}{*}{ Permian } & Zechstein (ZE) & Zechstein anyhydrites, rock salts & & & \\
\hline & & Upper Rotliegend (RO) & Slochteren Formation & - & & \\
\hline & \multirow{3}{*}{ Carboniferous } & \multirow{2}{*}{ Limburg (DC) } & Westphalian coals & & & $\bullet$ \\
\hline & & & Geverik Shale Member & & & • \\
\hline & & Carboniferous Limestone (CL) & Zeeland Formation & - & & - \\
\hline
\end{tabular}


These two salt deposits also form the most important caprocks for the Paleozoic gas system that is by far the largest in the Netherlands by volume. The major source rock for this system comes from Carboniferous coals. In the south-eastern tip of the country these coals are located much closer to the surface, where they were mined commercially up to the 1970s. Noteworthy reservoir rocks for this system are the Permian Slochteren Formation (which hosts the Groningen gas field) and the Triassic Main Buntsandstein Subgroup (Table 1). The lower Cretaceous claystones form the caprocks for a Mesozoic mixed oil and gas system, where the Jurassic Posidonia Shale Formation serves as the major source rock. Reservoirs are typically found in sandstones belonging to the Schieland and Rijnland Groups (Table 1). Salt diapirs formed by movement of the underlying Zechstein salt deposits have led to faulting (ten Veen et al., 2012) resulting in potential pathways for upward fluid movement. However, these diapirs as well as the associated faults have also been shown to contribute to trapping of hydrocarbons in these formations (Jager and Geluk, 2007). Lastly, the two shale formations in the Netherlands that have been identified to hold potentially economically viable gas contents are the aforementioned Posidonia Shale Formation and the Carboniferous Geverik Member (Bergen et al., 2013).

\section{3 | METHODS}

\subsubsection{Dataset 1: Nationwide methane concentrations}

\subsubsection{Data sources and data processing}

A dataset of methane concentrations in Dutch groundwater was compiled by datamining. The majority of data comes from two main sources: (1) monitoring data from drinking water production companies, and (2) all methane concentration data available in the online database of TNO Geological Survey of the Netherlands (www.dinoloket.nl). Samples in the dataset were collected in the period 1981 to 2013, with the exception of 3 samples that were collected decades earlier. Sampling methodologies used for individual samples are not traceable, however, the most commonly applied methodology is likely the inverted bucket method, given the time period. More advanced sampling methods were also used however, including sampling under high pressure in stainless steel vessels using submersible pumps. The inverted bucket methods have been shown to be reliable, at least up to concentrations where effervescence would occur at atmospheric conditions (Molofsky et al., 2016). Given the variety of sources and methods, the minimum reporting limit (MRL) also varied but an MRL of $0.01 \mathrm{mg} . \mathrm{L}^{-1}$ was most frequently encountered. To homogenize the dataset concentrations reported as zero or $<0.01 \mathrm{mg} . \mathrm{L}^{-1}$ were assigned values of $0.01 \mathrm{mg} \cdot \mathrm{L}^{-1}$.

The dataset consists of 12,219 datapoints. For quality control considerations, datapoints lacking information regarding either the sampled depth interval or the coordinates were excluded from the further analysis at this point. The samples were collected from 2,063 wells, including 426 multi-level monitoring wells that were sampled at at least 2 depths. The number of unique well screens in the dataset is 3,250. The median, 
average and maximum amount of samples collected from each well screen are 1, 3.6 and 31, respectively. Calculated coefficients of variation (CV) for wells screens with at least 2 samples are less than 0.2 in $52 \%$ of measurements. Only $3 \%$ of well screens have a CV larger than 1 (Figure 2). Out of only 4 well screens with a CV greater than 1 and an average methane concentration above $1 \mathrm{mg} \cdot \mathrm{L}^{-1}$, the maximum methane concentration was just $1.47 \mathrm{mg} \cdot \mathrm{L}^{-1}$. This shows that methane concentrations generally have low levels of natural temporal variability (or limitations in sampling) and hence averaged methane concentration values were used throughout the paper, unless otherwise noted. For each of these well screens the host formation, depositional environment and geological age were determined, based on the depth of the middle of the well screen and extracted from the Digital Geological Model of the Netherlands (DGM; www.dinoloket.nl).

Temporal variation

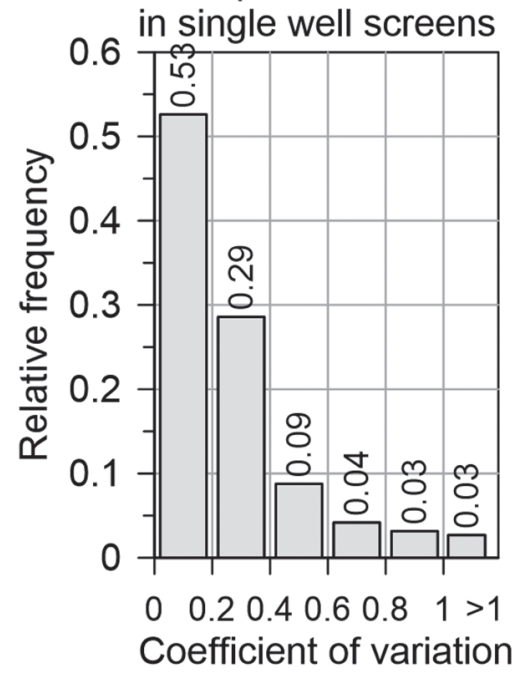

Figure 2 | Relative frequency histogram of the coefficient of variation $(\mathrm{CV})$ of methane concentrations for well screens that were sampled more than once. Only well screens with average methane concentrations $>0.01 \mathrm{mg} \cdot \mathrm{L}^{-1}$ were considered.

\subsubsection{2 | Statistical analysis}

Methane concentration data was grouped to test whether there were significant differences between subgroups of data based on: the stratigraphic unit at the well screen depth, the sedimentary depositional environment of the formation at the well screen depth, proximity to gas wells, proximity to faults penetrating the surficial Upper North Sea Subgroup, the presence of oil and gas reservoirs at the well location, the presence of the Posidonia Shale, the presence of the Geverik Shale, the presence of the Nieuwkoop Formation and the presence of the Eem Formation. The presence of Holocene marine sediments was also used, and the two categories formed by this subdivision will be referred to as the coastal lowlands versus the inland area. Threshold distances of 1 and $2.5 \mathrm{~km}$ were used to test whether proximity to oil and gas wells or faults influenced methane concentrations. The geospatial data 
used to make these groupings is shown in Figure S2. Given that distributions of methane concentrations tend to be positively skewed, the non-parametric Mann Whitney $U$ test was used to test for differences in median methane concentrations between two subgroups and the Kruskal-Wallis test for categories with more than two independent samples, as is typically done in statistical assessments of dissolved methane in groundwater (e.g. Atkins et al., 2015; Christian et al., 2016; Humez et al., 2016; Jackson et al., 2013). Kruskal-Wallis tests were extended by a stepwise stepdown multiple comparison post hoc procedure to determine statistical differences between the subsets. Statistical analyses of the methane concentration dataset were carried out using SPSS v25 and evaluated at p-values of 0.01 .

\subsubsection{Dataset 2: Targeted groundwater samples}

\subsubsection{1 | Sampling locations}

An additional 40 water samples were collected for more detailed isotopic analysis of dissolved gasses. The aim was to cover the entire depth interval, from shallow groundwater aquifers down to formation waters from the reservoir depth. In the following we consider shallow groundwater to be groundwater sourced from Neogene and younger formations - those where active groundwater circulation takes place in most of the country. Shallow groundwater sampling locations were selected based on likelihood of encountering thermogenic methane or because anomalously high methane concentrations had been observed before. Likelihood of encountering thermogenic methane was deemed high when water wells were located in close proximity to a fault penetrating through to the surficial Upper North Sea Subgroup, a salt diapir, and/or were situated above a known gas reservoir. In total, water samples were collected from 17 such groundwater wells (Figure 1). Two of these 17 were multi-level monitoring wells that were sampled at four different depths each (SGW-02 and SGW-16). The 15 other wells were only sampled at one depth. The depth of the middle of the well screen for wells in this category ranged from 5 to 280 mbgs.

A further 11 samples were collected from deep groundwater wells (Figure 1), which in this context we consider to be below the Paleogene Rupel Clay Member. The relatively small areas of the country where this formation is not present where therefore excluded. Local geology was determined using DGM. Given the large depth of the Rupel Clay Member in most of the country, the salinity of the water at these depths, and the typically poor productivity of Paleogene formations, no more wells could be sampled. Also, the 11 sampled wells are all situated near the southern and eastern border of the country, given that the depth of the Rupel Formation increases rapidly towards the north-west of the country (following the general pattern of the Breda Formation, Figure 1B). The depth of the middle of the well screens for the sampled wells in this category ranges from 130 to $871 \mathrm{mbgs}$ (Table 3). The majority of sampled deep and shallow groundwater wells were collected from dedicated groundwater monitoring wells with short well screen lengths $(<3 \mathrm{~m})$. A subset of samples were collected from groundwater production wells with well screens ranging from $10-30 \mathrm{~m}$.

Besides groundwater wells, molecular and isotopic compositions of dissolved gasses were also analysed for 6 samples retrieved from geothermal wells (Figure 1), that range 
in depth from 1640 to 2625 mbgs. Results of these analyses, as well as that of 9 shallow groundwater wells have been reported before in Dutch literature (Cirkel et al., 2015; Table 3). For comparison, isotopic compositions of natural gas from Dutch oil and gas wells were retrieved from the governmental 'Netherlands Oil and Gas Portal' (NLOG, 2020). Lastly, the water composition of 10 samples from oil field formation waters (Eggenkamp, 1994) was reanalysed. These samples were retrieved from oil wells in the west of the Netherlands in 1983 and preserved in glass bottles with a thick oil layer on top of the water. The depth of these wells ranges from 950 to 1766 mbgs. However, due to the age of these samples and lack of preservation measures they were not re-analyzed for dissolved gas isotopic composition.

\subsubsection{2 | Sampling \& analysis}

Groundwater samples were collected between June $22^{\text {nd }}, 2016$, and February $26^{\text {th }}, 2018$. Wells were purged prior to sampling until around three times the total volume of water in the well tube had been flushed or after the temperature, $\mathrm{pH}$ and electrical conductivity of the water had stabilized and dissolved oxygen indicated stable anoxic conditions. Different pumps were used depending on the casing diameter and groundwater level. Submersible pumps were used for wells with casing diameters $>2$ " and peristaltic pumps for diameters $<2$ ". Inertial pumps had to be used in two cases (DGW-08 and DGW-09), as the casing diameters were $<2$ " and groundwater heads were too deep to use a peristaltic pump. Samples were filtered through $0.45 \mu \mathrm{m}$ pore filters and stored at $5^{\circ} \mathrm{C}$ until analysis. Samples for ICP-OES analysis were acidified using $\mathrm{HNO}_{3}$. Major anions and cations were determined using ion chromatography (IC) and inductively coupled plasma optical emission spectrometry (ICP$\mathrm{OES})$, respectively. Alkalinity was determined using titration with sulfuric acid and ammonium concentrations using a photo spectrometer.

Samples for the analysis of molecular and isotopic composition of dissolved gasses were collected in Isoflasks ${ }^{\circledast}$ that were connected directly to the pump tubing to avoid loss of gas to the atmosphere. However, this was not possible for the two samples collected using a inertial pump; here, water was first pumped into a bucket and subsequently pumped into the Isoflasks ${ }^{\circledast}$ using a peristaltic pump. Analysis of dissolved gasses was carried out by ISOLAB, the Netherlands. Samples were allowed to equilibrate to the room temperature and air pressure of the laboratory. Subsequently, the total headspace gas was extracted using a syringe. The total water volume was determined by weighing the samples. Meanwhile, the pressure and temperature in the laboratory were recorded with which the mass concentration of gas components in the aqueous phase of the original sample were back calculated using Henry's law. Up to three Isoflasks were used per well to ensure sufficient gas was available to analyse at least the gas composition and $\delta^{13} \mathrm{C}-\mathrm{CH}_{4}$ ratio reliably. Gas composition was analysed on an Agilent 6890N/7890A/7890B Gas Chromatograph (GC). Carbon isotopes of methane were analysed with an Agilent 6890N GC interfaced to a Finigan Delta S isotope-ratio mass spectrometer (IRMS). Carbon isotopes of $\mathrm{C}_{2}, \mathrm{C}_{3}$ and $\mathrm{CO}_{2}$, as well as hydrogen isotopes of $\mathrm{C}_{1}$ were analysed on an Agilent 7890A GC interfaced to a MAT 253 IRMS. Isotopic compositions 
of carbon and hydrogen are reported relative to PDB and SMOW standards, respectively, using the standard delta notations (e.g. Whiticar, 1999).

Chloride stable isotope ratio $\left({ }^{37} \mathrm{Cl} /{ }^{35} \mathrm{Cl}\right)$ was determined by mass spectrometry on chloromethane $\left(\mathrm{CH}_{3} \mathrm{Cl}\right)$ following the procedures in Eggenkamp (1994) at the Institut de Physique du Globe de Paris (IPGP). $\delta^{37} \mathrm{Cl}$ is reported relative to the Standard Mean Ocean Chloride standard (SMOC). $\delta^{37} \mathrm{Cl}$ was only determined for the deep groundwater samples, a subset of the shallow groundwater samples, and the formation waters. For the formation waters, obtained values were in good agreement with reported values in Eggenkamp (1994), who also analysed $\delta^{37} \mathrm{Cl}$ values for 8 out of the 10 available samples. Only 1 of the 10 samples showed a large increase in chloride concentrations over this time due to evaporation caused by improper sealing of the bottle. Nevertheless, the difference in $\delta^{37} \mathrm{Cl}$ was only $0.2 \%$. The average difference between reported $\delta^{37} \mathrm{Cl}$ in 1994 and now was only $0.08 \%$, which shows that the consistency of the measurement technique is high. $\delta^{13} \mathrm{C}$ of dissolved inorganic carbon (DIC) and subsequently ${ }^{14} \mathrm{C}$ activity were determined by the Centre for Isotope Research (CIO), University of Groningen, on an Accelerator Mass Spectrometer (AMS). Samples for ${ }^{14} \mathrm{C}$ determination were collected in dark glass bottles and sterilized using a $\mathrm{I}_{2}-\mathrm{KI}$ solution.

${ }^{14} \mathrm{C}$ activity is reported as percentage modern carbon (pMC). Conversion of ${ }^{14} \mathrm{C}$ activity to pMC was done according to definitions in Mook and Plicht (1999). ${ }^{14} \mathrm{C}$ was only determined for the deep groundwater samples and a subset of the shallow groundwater samples.

\section{4 | RESULTS AND DISCUSSION}

\subsubsection{Nationwide groundwater methane concentration dataset}

Median and average and maximum methane concentrations in the 3,250 well screens in the dataset were $0.20 \mathrm{mg} . \mathrm{L}^{-1}, 3.00 \mathrm{mg} . \mathrm{L}^{-1}$ and $96.50 \mathrm{mg} . \mathrm{L}^{-1}$, respectively. This shows that methane concentrations are positively skewed, as is typically observed in dissolved methane baseline studies. Concentrations are greater than $0.01 \mathrm{mg} \cdot \mathrm{L}^{-1}$ in $79 \%$ of the well screens. The $10 \mathrm{mg} \cdot \mathrm{L}^{-1}$ and $28 \mathrm{mg} \cdot \mathrm{L}^{-1}$ hazard mitigation threshold values proposed by the US Department of the Interior (Eltschlager et al., 2001) are exceeded in $7.5 \%$ and $2.8 \%$ of well screens. Median methane concentrations in the Netherlands are considerably higher than those observed in the neighbouring German state of Lower Saxony ( 0.002 mg. $\mathrm{L}^{-1}$, Schloemer et al., 2016), which borders the Netherlands in the north-east, and in Great Britain, where the largest median value was observed for South Wales ( 0.032 mg. $\mathrm{L}^{-1}$, Bell et al., 2017). While dissolved methane concentrations in the Netherlands are thus relatively high, much higher median methane concentrations have been observed at the regional scale, such as in the Los Angeles Basin (39 mg.. ${ }^{-1}$, Kulongoski et al., 2018).

\subsubsection{1 | Methane concentrations and depth}

Methane concentrations varied significantly with depth within sampled multilevel wells (Figure S3). Out of 368 groundwater wells with at least two sampled well screens with 
methane concentrations $>0.01 \mathrm{mg} \cdot \mathrm{L}^{-1}$, the coefficient of variation, calculated as the standard deviation of the methane concentrations in the well screens present in the well divided by their total mean concentration, was greater than 1.0 in $20 \%$ of wells. For this group, 33 of the 76 wells had a mean methane concentration above $1 \mathrm{mg} \cdot \mathrm{L}^{-1}$, showing that such variability did not only at the low end of the methane concentration range. This vertical spatial variability is much greater than the variability of methane concentrations within single well screens over time (Figure 2).

Overall, median methane concentrations per depth interval increase with depth down to 100 - 140 mbgs, where they exceed $1 \mathrm{mg} \cdot \mathrm{L}^{-1}$. Below $140 \mathrm{mbgs}$ median concentrations gradually drop off again to $0.02 \mathrm{mg} \cdot \mathrm{L}^{-1}$ for depths greater than $240 \mathrm{mbgs}$. Maxima vary between 40 - $100 \mathrm{mg} \cdot \mathrm{L}^{-1}$ down to $140 \mathrm{mbgs}$, after which they drop off to around $10-20 \mathrm{mg} \cdot \mathrm{L}^{-1}$. Only the maximum reported single measurement (before averaging concentrations over time in each well screen) of $120 \mathrm{mg} \cdot \mathrm{L}^{-1}$ exceeded the theoretical solubility corresponding to the depth of middle of the well screen and a 100\% methane mole fraction ( $96 \mathrm{mg} \cdot \mathrm{L}^{-1}$ at 22.3 mbgs). The pattern of decreasing methane concentrations with depth suggests the high concentrations result from local biogenic methanogenesis rather than diffusion from underlying sources of methane, which would yield an overall pattern of increasing methane concentrations with depth.

When isolating the wells that are in the coastal lowlands ( $n=369$, Figure $1 \mathrm{~A})$, methane concentrations show a distinctly different pattern. Median concentrations are greatest at shallow depths and peak between $40-60$ mbgs at $4.0 \mathrm{mg} \cdot \mathrm{L}^{-1}$, compared to just $0.2 \mathrm{mg} \cdot \mathrm{L}^{-1}$ in the same depth interval in the inland areas (Figure 3). Furthermore, the variability in methane concentrations down to around $100 \mathrm{mbgs}$ is more significant in this area, as shown by the greater interquartile range. However, from 100 - 160 mbgs, both median and $3^{\text {rd }}$ quartile concentrations are actually smaller in the Holocene part of the country. At this depth interval, third quartile concentrations in the inland areas are around $4 \mathrm{mg} \cdot \mathrm{L}^{-1}$. The lower methane concentrations at these depths in the coastal lowlands versus the inland areas can possibly be explained by the generally more shallow depth of the fresh-salt interface in this region (Mendizabal et al., 2011) and hence the prevalence of sulphate, which prevents methanogenesis (Molofsky et al., 2018). These results give a more nuanced picture of methane concentrations in the country than earlier work by Fortuin and Willemsen (2005), who concluded that the highest concentrations occur at shallow depth in the presence of reactive organic matter such as peat. While this is indeed true for the coastal areas, there are other sources of methane in slightly deeper groundwaters aquifers in the inland areas, resulting in overall higher concentrations there. 


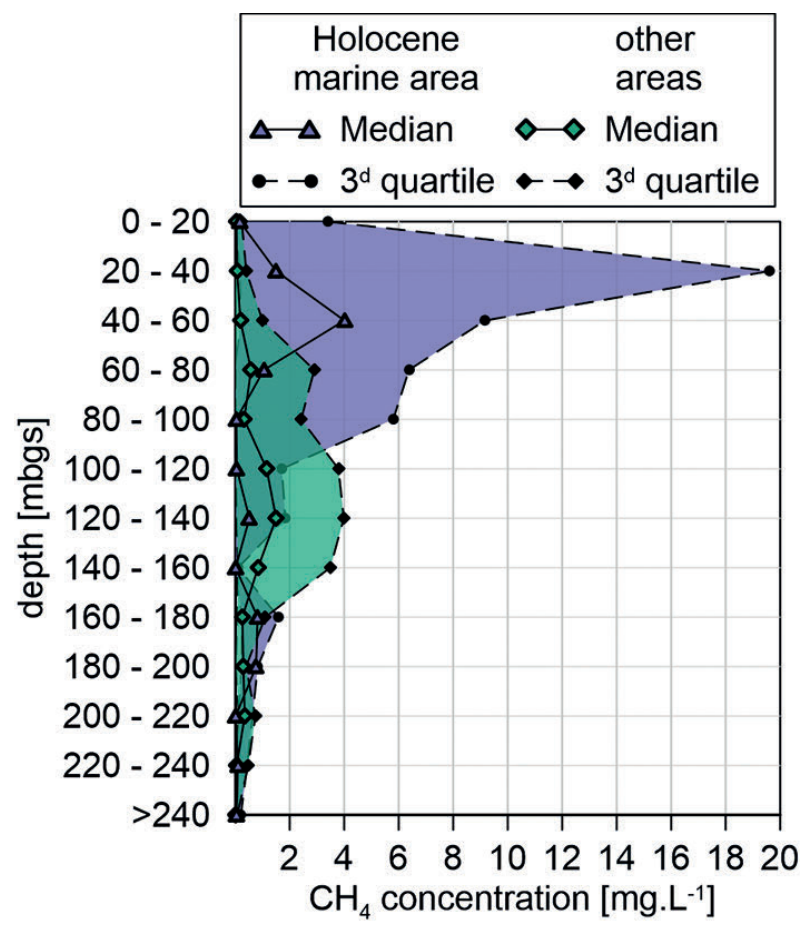

Figure 3 | Medians and interquartile range of methane concentrations per depth interval of twenty meters. Results are shown for wells in the part of the country with Holocene marine sediments (purple) and other areas (green), as per the red line in Figure $1 \mathrm{~A}$.

\subsubsection{2 | Depositional environment and stratigraphic unit}

Methane concentrations in water samples from glacial deposits $\left(1.7 \mathrm{mg} . \mathrm{L}^{-1}\right)$ are significantly higher than in sediments with other depositional origins (Figure 4A). This finding appears consistent with observations in US groundwater, where methane concentrations were also higher in unconsolidated glacial sediments than in unconsolidated non-glacial sediments (McMahon et al., 2017). However, median concentrations in glacial sediments in the US ( $\left.\sim 0.001 \mathrm{mg} . \mathrm{L}^{-1}\right)$ are much lower overall than in the Netherlands. Concentrations in formations of marine and fluvial origin are lower and not significantly different from one another, with median concentrations of 0.21 and $0.31 \mathrm{mg} \cdot \mathrm{L}^{-1}$, respectively. Median concentrations in formations with other depositional origins were again statistically significantly lower with a median of just $0.02 \mathrm{mg} \cdot \mathrm{L}^{-1}$. Most of the samples in this category are from formations with a aeolian origin, or from ice pushed ridges. These generally very permeable sandy formations serve as important infiltration areas for groundwater in the Netherlands. Hence, the observed low methane concentrations are not surprising, given the predominant Fe-anoxic redox state of the groundwater (Griffioen et al., 2013).

Multiple comparison testing on the stratigraphic units in which wells were screened revealed a more complex picture, with significant differences between 9 homogeneous subsets that are much larger than the differences between the depositional environments (Figure 4B). The highest median concentrations were observed in the glacial Peelo Formation (4.85 mg. $\left.\mathrm{L}^{-1}\right)$, much larger than those in the Drente Formation $\left(0.14 \mathrm{mg} \cdot \mathrm{L}^{-1}\right)$, which is the only other glacial formation in the Netherlands. Organic matter content in the Peelo Formation 
is indeed known to be higher than in the Drente Formation, particularly in the clay deposits that can be more than hundred meter thick where they have partially infilled deeply incised subglacial tunnels that are not present in the Drente Formation (Griffioen et al., 2016). The data shows that local methanogenesis in these clays is likely a source of dissolved methane in the Netherlands.

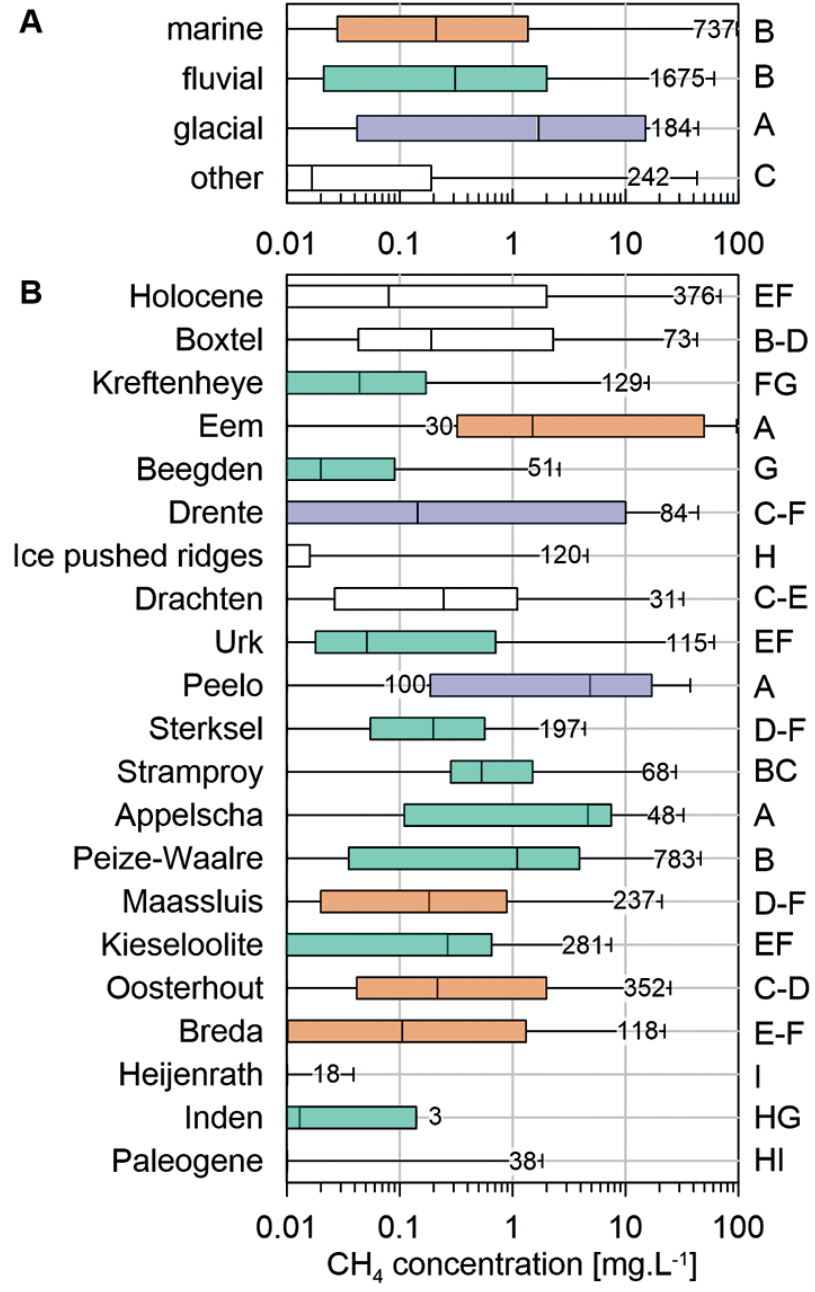

Figure 4 | Box and whisker plots of methane concentrations versus depositional environment (A) and versus Neogene and Quaternary geological units $(B)$, shown in order of increasing age (as per Figure S1). Concentrations in Holocene (not including the Boxtel Formation) and Paleogene formations are aggregated in plot $B$ and excluded from $A$. Colours in B indicate the depositional environment as per plot A (Fluvial $=$ Green, Marine $=$ Orange, Glacial = Purple, White $=$ Other). Boxes represent values within the $25^{\text {th }}$ and $75^{\text {th }}$ percentile, whiskers the minimum and maximum concentrations. Number labels show the total number of samples per category, capital letters indicate homogeneous subsets following the multiple comparison test procedure.

Median methane concentrations in marine deposits are highest in the Late Pleistocene Eem Formation (1.50 mg. $\left.\mathrm{L}^{-1}\right)$. Third quartile concentrations in the Eem Formation are particularly high at $49.6 \mathrm{mg} \cdot \mathrm{L}^{-1}$, indicating that significant methanogenesis likely occurs in this formation. This corresponds to findings of shallow gas in the Danish subsurface, which were contributed to significant methanogenesis in a comparable Late Pleistocene marine formation formed in 
glacial basins (Laier et al., 1992). Median concentrations in Neogene and Early Pleistocene marine deposits were considerably lower $\left(<0.22 \mathrm{mg} \cdot \mathrm{L}^{-1}\right)$. Only 5 of 38 total measurements in Paleogene marine formations were above the $\mathrm{MRL}$, and only 1 greater than $1 \mathrm{mg} \cdot \mathrm{L}^{-1}$. This finding also follows from the low observed methane concentrations at depths greater than roughly 200 mbgs (Figure 3), where the Paleogene formations typically occur in the Netherlands. Similarly, methanogenesis in these formations does not have to be carbon limited but is more likely the result of unfavourable redox conditions due to the presence of $\mathrm{SO}_{4}$ rich saline groundwater.

The occurrence of methane in fluvial deposits also varies greatly, with median concentrations in the Appelscha Formation (4.65 mg. $\mathrm{L}^{-1}$ ) and to a lesser extent the combined Peize and Waalre Formations $\left(1.10 \mathrm{mg} \cdot \mathrm{L}^{-1}\right)$ being significantly larger than in other fluvial deposits. A local methanogenic source is less likely in these formations, given that they are characterized by medium to coarse grain sands and gravel (Griffioen et al., 2016) that are not typically associated with high organic matter contents. Since the Appelscha Formation overlies the Peize-Waalre Formation, the occurrence of high concentrations of dissolved methane here is more likely attributable to varying overlying sources, such as the Peelo clays, the Marine Eem Formation or Holocene deposits. One may note that the ice-pushed ridges, which are frequently composed of fluvial sediments from the Urk Formation, have very low methane concentrations, with third quartile concentrations just slightly higher than $0.01 \mathrm{mg} \cdot \mathrm{L}^{-1}$.

Surprisingly, the median methane concentration in Holocene deposits is only $0.08 \mathrm{mg} \cdot \mathrm{L}^{-1}$. However, the interquartile range is relatively large. The high methane concentration observed at shallow depth in the Holocene marine area (Figure 3) are therefore likely very local phenomena, linked to reactive carbon in peat of the Nieuwkoop Formation and/or the marine Holocene Naaldwijk Formation.

\subsubsection{3 | Spatial position}

The spatial distribution of methane concentrations was tested by comparing the average and median concentration in a subset of wells that overlap with a certain spatial criteria (Figure S2) to those that don't. The biggest difference in average methane concentrations was observed for the subset of wells overlapping with the Holocene Nieuwkoop Formation (10.1 mg. $\left.\mathrm{L}^{-1}\right)$, which is the major peat formation in the Netherlands. The difference in median concentrations was $\left(7.1 \mathrm{mg} . \mathrm{L}^{-1}\right)$, which again shows that the highest methane concentrations are local phenomena. The difference in median and average methane concentrations for wells in the area with Holocene marine deposits (Figure 1A) was much smaller ( 0.5 and 4.7 mg. $\mathrm{L}^{-1}$, respectively). This suggests that the Holocene marine deposits might play a smaller role in determining methane concentrations than the presence of peat does. Surprisingly, methane concentrations in wells that intersect the Eem Formation were not significantly elevated (Table 2), in spite of the high observed concentrations in samples directly from the Eem Formation. The discrepancy results from the fact that while 283 samples are from wells that intersect the Eem Formation, only 30 water samples were directly obtained from it (Figure 4). 
This highlights a key limitation of using statistical analysis of horizontal spatial relations for determining sources of groundwater methane, which in reality are determined by depth and time dependent processes.

Differences in median concentrations were also high for wells with overlap with known oil and gas reservoirs as a criterion $\left(7.3 \mathrm{mg} \cdot \mathrm{L}^{-1}\right)$. To a lesser extent, median concentrations in groundwater wells in close proximity to gas wells were also substantially higher than those further away, for both cut off distances of 1 (2.9 mg. $\left.\mathrm{L}^{-1}\right)$ and $2.5 \mathrm{~km}\left(2.7 \mathrm{mg} . \mathrm{L}^{-1}\right)$, respectively. Whether this is evidence of a deep, thermogenic source at play in controlling the methane concentrations is questionable however. There is strong overlap between the occurrence of peat and that of oil and gas accumulations in the Netherlands (Figure S2), which cannot be distinguished between here. Although a dominantly biogenic origin of methane remains the most likely factor controlling methane concentrations in the Netherlands, a local thermogenic source near gas wells or above oil and gas fields in general cannot be ruled out on the basis of methane concentrations alone. Hence, isotopic evidence is required to determine whether a substantial thermogenic component contributes to the elevated concentrations above oil and gas fields and near gas wells. The spatial analysis did reveal that other potential deep sources of methane in shallow groundwater can be ruled out, as concentrations in groundwater wells near faults were not significantly different, and methane concentrations above the Posidonia and Geverik shales differed less than $1 \mathrm{mg} \cdot \mathrm{L}^{-1}$ with those that do not overly these formations.

Table 2 | Difference in mean and median values for subgroups of well screens using a criterion with respect to a given threshold distance of or intersecting a certain spatial feature (shown in Figure S2) that is a potential source of methane in shallow groundwater. P-values are for associated Mann-Whitney U tests.

\begin{tabular}{|c|c|c|c|c|c|}
\hline Criterion & $\begin{array}{l}\text { Threshold } \\
\text { distance }\end{array}$ & $\begin{array}{c}n \\
\text { (3250 total) }\end{array}$ & $\begin{array}{c}\Delta \text { Mean } \\
\text { (inside - outside) }\end{array}$ & $\begin{array}{c}\Delta \text { Median } \\
\text { (inside - outside) }\end{array}$ & p-value \\
\hline Distance to gas well & $<1 \mathrm{~km}$ & 56 & 4.7 & 2.9 & $<0.01$ \\
\hline Distance to fault & $<1 \mathrm{~km}$ & 735 & -1.6 & 0.1 & 0.60 \\
\hline Distance to gas well & $<2.5 \mathrm{~km}$ & 241 & 3.7 & 2.7 & $<0.01$ \\
\hline Distance to fault & $<2.5 \mathrm{~km}$ & 1194 & -2.2 & 0.0 & 0.21 \\
\hline Oil or gas reservoir & Intersect & 115 & 6.5 & 7.3 & $<0.01$ \\
\hline Posidonia Shale & Intersect & 823 & -0.8 & 0.7 & $<0.01$ \\
\hline Geverik Shale & Intersect & 841 & -0.5 & -0.1 & $<0.01$ \\
\hline Coastal lowlands & Intersect & 369 & 4.7 & 0.5 & $<0.01$ \\
\hline Nieuwkoop Formation & Intersect & 167 & 10.1 & 7.1 & $<0.01$ \\
\hline Eem Formation & Intersect & 283 & 2.3 & 0.0 & 0.62 \\
\hline
\end{tabular}




\subsubsection{Methane origin in targeted groundwater samples}

Methane concentrations in the targeted samples from shallow groundwater ranged up to $79 \mathrm{mg} \cdot \mathrm{L}^{-1}$, compared to a maximum methane concentration of just $0.18 \mathrm{mg} \cdot \mathrm{L}^{-1}$ in the deep groundwater samples (Figure 5). Even the smallest concentrations were still considerably higher than methane concentrations of groundwater in contact with air at $10^{\circ} \mathrm{C}$ ( 0.00006 mg. $\left.\mathrm{L}^{-1}\right)$. Methane concentrations above $3 \mathrm{mg} \cdot \mathrm{L}^{-1}$ only occurred in samples with sulphate concentrations below $3 \mathrm{mg} \cdot \mathrm{L}^{-1}$, and vice versa (Table 3). Two samples had higher co-occurring concentrations, but these were taken from wells with long well screen lengths, which can allow for mixing of different water types. The low methane concentrations in the deeper groundwater samples are therefore likely attributable to redox conditions that are unfavourable for microbial methanogenesis, as sulphate concentrations ranged from 4 to $1591 \mathrm{mg} \cdot \mathrm{L}^{-1}$ in these waters.

\section{- Shallow aquifers}

All but one of the shallow groundwater samples with methane concentrations greater than $1 \mathrm{mg} \cdot \mathrm{L}^{-1}$ had a ${ }^{13} \mathrm{C}-\mathrm{CH}_{4}<-60 \%$, indicative of a biogenic origin, with the exception of the sample collected near the blowout in Sleen (SGW-09). A follow up study carried out at this location showed that leakage of natural gas has been ongoing for several decades. As such, the sample proved to be clear evidence of an anthropogenically opened connection with the deep subsurface (Schout et al., 2017). The $\delta D-\mathrm{CH}_{4}$ values for shallow groundwater samples with biogenic methane in concentrations $>1 \mathrm{mg} \cdot \mathrm{L}^{-1}$ were around $-250 \%$ or higher, which suggests that $\mathrm{CO}_{2}$ reduction is the dominant methanogenic pathway (Whiticar, 1999). This was also found to be the dominant methanogenic process in numerous other groundwater methane baseline studies worldwide (e.g. Humez et al., 2016; Kulongoski et al., 2018; McIntosh et al., 2014; Nicot et al., 2017).

Five samples from the shallow aquifers had $\delta^{13} \mathrm{C}_{-} \mathrm{CH}_{4}$ values above $-50 \%$ (Table 3), typically associated with a thermogenic origin. For two of the samples, the combination of $\delta^{13} \mathrm{C}-\mathrm{CH}_{4}$ and the light alkane ratio $\left(\mathrm{C}_{1} /\left(\mathrm{C}_{2}+\mathrm{C}_{3}\right)\right.$ even closely resembles that of SGW-09 from the blowout site, which in turn is similar to that of natural gas reservoirs in the Netherlands (Figure 6A). However, these fives samples all show extreme deuterium enrichment with $\delta D-$ $\mathrm{CH}_{4}$ values between 100 and $300 \%$ (Figure 6B). Such highly enriched values have previously been associated with fractionation caused by methane oxidation (Etiope et al., 2011; Schloemer et al., 2016). Rayleigh fractionation modelling with carbon isotope fractionation factors $\varepsilon_{c}$ of 7 and 12 (definitions in Whiticar, 1999) confirms that this shift in isotopic and molecular composition of the dissolved gasses in these samples can indeed be attributed to methane oxidation (Figure 6A). 


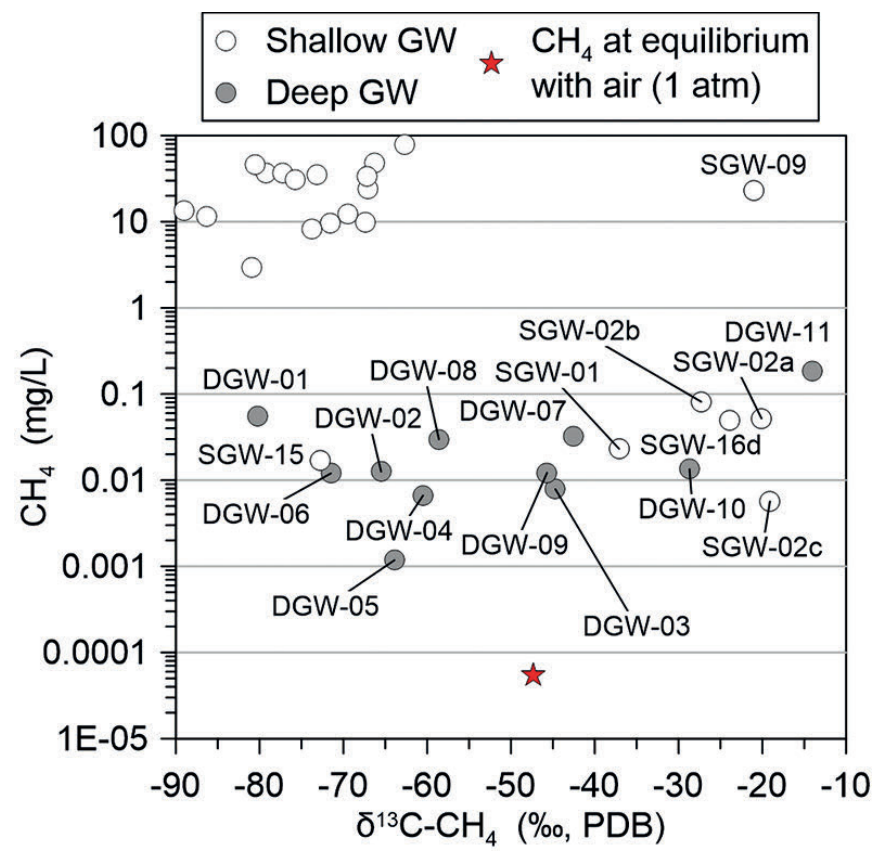

Figure $5 \quad$ Methane concentrations versus carbon isotopic composition $\left(\delta^{13} \mathrm{C}-\right.$ $\mathrm{CH}_{4}$ ) in targeted samples from deep and shallow groundwater.

The process by which these anomalous isotopic values came to be is best illustrated by the analyses of the four samples collected in the multi-level monitoring wells SGW-02 and SGW-16. For example, only the sample collected from the greatest depth in SGW-02 has high methane concentrations (SGW-02d, $36 \mathrm{mg} \cdot \mathrm{L}^{-1}$ ), negligible sulphate concentrations and a clear biogenic isotopic composition. The three other samples collected from the overlying well screens all have trace amounts of methane and high sulphate concentrations (Table 3). The extreme deuterium enrichment in these samples is well explained by isotopic fractionation factors $\varepsilon_{C}$ of 12 and $\varepsilon_{D}$ of 96 (Figure $6 \mathrm{~B}$ ), that fall within the observed range of fractionation factors for microbial methane consumption (Whiticar, 1999), leading to an enrichment ratio $\left(\Delta \mathrm{D} / \Delta^{13} \mathrm{C}\right)$ of 8 . Using this method, an estimated $99 \%$ of the initial methane would have had to be oxidized to reach such extremely enriched values. Given the low $\mathrm{CH}_{4}$ concentrations $\left(<0.1 \mathrm{mg} \cdot \mathrm{L}^{-1}\right)$ this still corresponds to only a minor amount of oxidation in absolute terms. Hence, rather than a thermogenic origin and connection with the deep subsurface, methane in these wells is linked to transport away from a nearby biogenic source that has subsequently been transformed isotopically as a result of anaerobic oxidation of methane (AOM). 

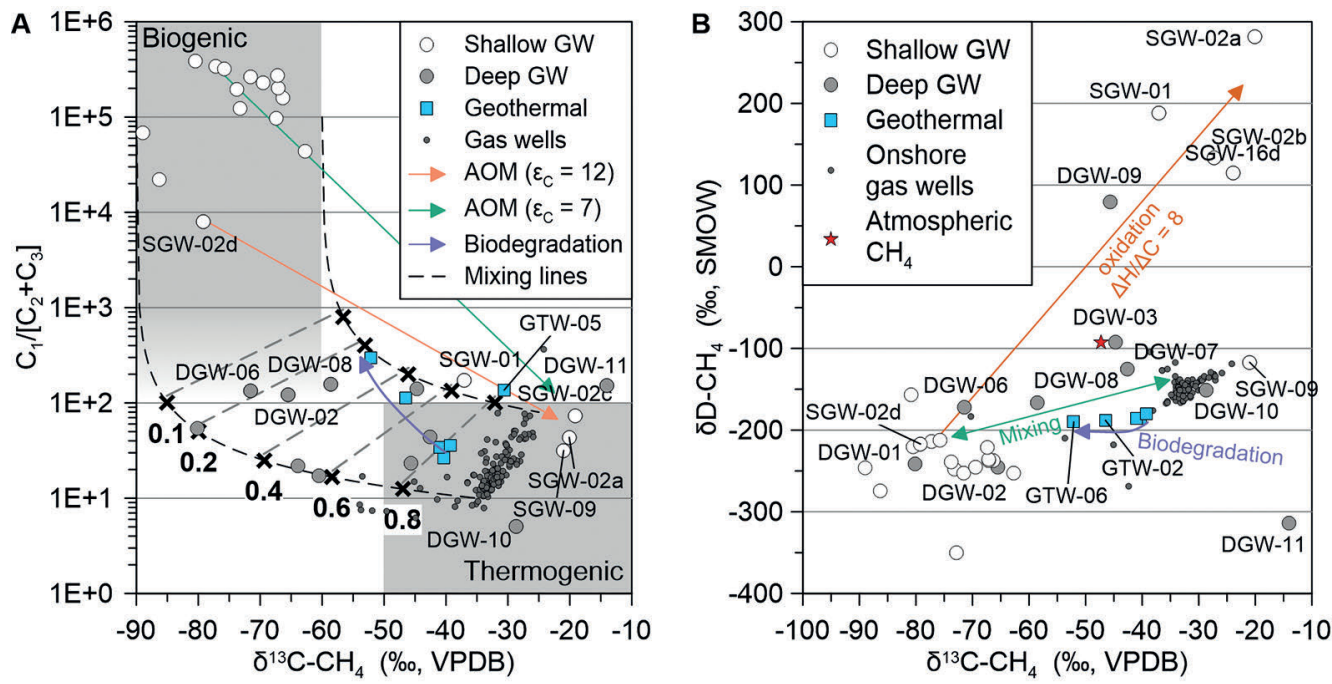

Figure 6 | Methane carbon isotope ratio versus light alkane ratio (A) and hydrogen isotope ratio (B), for gasses found in Dutch shallow groundwater, deep groundwater, geothermal wells and natural gas accumulations. Dashed black lines show hypothetical mixing lines for biogenic and thermogenic gas, with bold labels in A showing the fraction of thermogenic gas in the mixture. Green and orange lines in A depict the calculated effect of anaerobic methane oxidation (AOM) for two carbon fractionation factors $\left(\varepsilon_{\mathrm{c}}\right)$. Orange line in $B$ depicts isotopic fractionation up to a residual methane fraction of $1 \%$ with fractionation factors $\varepsilon_{\mathrm{C}}=12$ and $\varepsilon_{\mathrm{D}}=96$. Calculations according to formulations in Whiticar (1999).

\section{- Paleogene and older deep aquifers}

In spite of the low methane concentrations and the presence of sulphate in all deep groundwater samples, only sample DGW-09 displays a similar shift in both isotopic and molecular composition that clearly shows the impact of AOM (Figure 6B). The other samples (except two; see discussion below) lie somewhere on a mixing line, and hence the small mass concentrations appear to consist of varying fractions of biogenic and thermogenic methane (Figure 6A). Measurements of the $\delta^{13} \mathrm{C}$ of ethane and propane corroborate the conclusion of a mixed origin for these samples, as their $\delta^{13} \mathrm{C}_{-} \mathrm{C}_{2} \mathrm{H}_{6}$ composition resembles that of Dutch natural gas samples closely, and is notably different from the ethane in the shallow groundwater samples with biogenic methane (Figure 7). Since the fraction of ethane in thermogenic gas is much greater than in biogenic gas, even mixtures with a small thermogenic component should show a clear thermogenic ethane signature, in conjunction with a mixed isotopic signature of methane which shifts more or less linearly with the fraction of thermogenic methane. Therefore, the lighter ethane signature in the shallow groundwater samples also provides evidence for a lack of even small amounts of thermogenic methane at these depths. This analysis clearly shows the added value $\delta^{13} \mathrm{C}_{-} \mathrm{C}_{2} \mathrm{H}_{6}$ as a tracer for gas migration. However, the amount of sampled ethane is often too small to reliable measure its 
isotopic composition, which also explains the missing data for a number of samples in this study (Table 3). Increasing the sampled volume could circumvent this issue, however, this may significantly increase sampling efforts depending on its methodology. Furthermore, similar to methane oxidation, preferential oxidation of ethane may also occur in freshwater aquifers (Schout et al., 2018), which can obscure the interpretation of ethane isotopes.

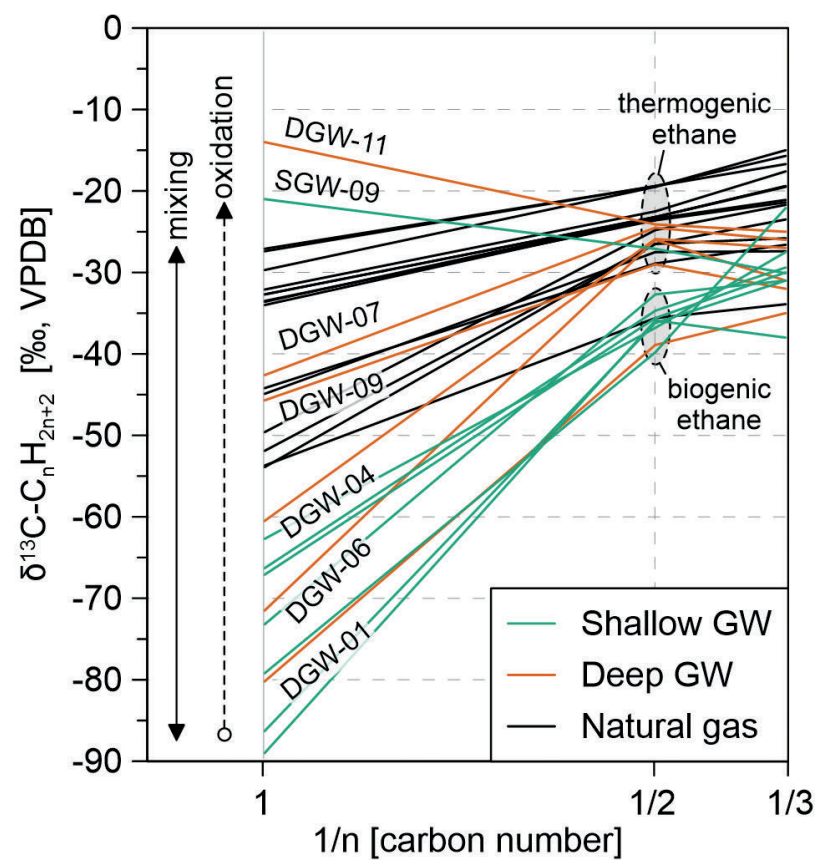

Figure 7 | 'Gas plot' of carbon isotopic composition versus carbon number for methane $\left(C_{1}\right)$, ethane $\left(C_{2}\right)$ and propane $\left(C_{3}\right)$ in gasses found in Dutch shallow groundwater, deep groundwater, and natural gas accumulations. Also shown are potential effects of oxidation and mixing on methane isotopes and ranges of $\delta^{13} \mathrm{C}_{2} \mathrm{H}_{6}$ values interpreted to represent either biogenic or thermogenic ethane.

Two exceptions to a mixed or biogenic origin are the samples from wells DGW-10 and DGW11 (Figure 6). DGW-10 is located in the east of the Netherlands and screened at a depth of nearly $700 \mathrm{~m}$ (Table 3). It has a isotopic composition that is comparable to that of natural gas reservoirs in the Netherlands and therefore presents clear evidence of upward seepage of thermogenic methane up to at least this depth (Figure $6 B$ ). The $C_{1} /\left(C_{2}+C_{3}\right)$ ratio of 5 , slightly lower than that of Dutch natural gas, likely indicates that some oxidation has occurred after or during migration. Sample DGW-11 has an enriched $\delta^{13} \mathrm{C}^{-} \mathrm{CH}_{4}$ composition $(-14 \%$ o) that is similar to some of the oxidized shallow samples. However, the combination with its $\delta \mathrm{D}-\mathrm{CH}_{4}$ value of $-314 \%$ places it outside of the traditionally delineated areas for thermogenic and/or biogenic methane, and actually suggests an abiotic methane origin according to 
classifications in Milkov and Etiope (2018). While such a finding would present a first for the Dutch subsurface (to the author's knowledge), additional evidence for this conclusion is presented by the reversed $\delta^{13} \mathrm{C}$ trend of the light alkanes $\left(\delta^{13} \mathrm{C}-\mathrm{C}_{1}>\delta^{13} \mathrm{C}-\mathrm{C}_{2}>\delta^{13} \mathrm{C}-\mathrm{C}_{3^{\prime}}\right.$ Figure 7), which is a known characteristic of abiotic gas (Lollar et al., 2006). While no clear evidence is given in the lithological description of the cuttings collected while drilling well DGW-11, intrusions of volcanic rocks are known to be present in the Carboniferous and Permian formations that lie at the base of this well, such as for example the Carboniferous Baarlo Formation (Sissingh, 2004). In the presence of such intrusions, the low concentration of methane in this sample could be the result of catalytic $\mathrm{CH}_{4}$ generation. In experiments with serpentinized rocks, this process has been shown to occur down to temperatures as low as $20^{\circ} \mathrm{C}$ (Etiope and lonescu, 2015), considerably lower than the estimated $37^{\circ} \mathrm{C}$ in well

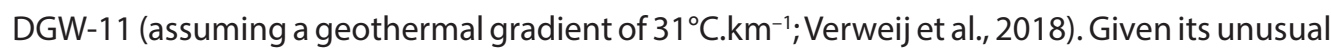
composition compared to the gas in all other groundwater samples, additional evidence would be needed to verify the abiotic origin of dissolved methane in DGW-11.

Dissolved gas in the geothermal wells is distinct from that of Dutch gas wells, and has a geochemical signature that falls within the range of values associated with mixing of biogenic and thermogenic gasses (Figure 6A). However, the depths (1640 - 2625 m, Table 3) and estimated temperature range of these wells is not typically associated with biogenic methane accumulations. Moreover, wells GTW-01 to GTW-04 are completed in the same formations as (depleted) Lower Cretaceous oil reservoirs, where biodegraded oils are known to be present (Griffioen et al., 2016). Hence, an oil associated origin is more probable. The dissolved gas isotopic and molecular signature confirms this hypothesis, as it closely matches that of oil associated methane (Milkov and Etiope, 2018). Additionally, the shift in isotopic and molecular composition observed for GTW-02 and GTW-06 matches the shift that is observed for methanogenic biodegradation of oils (Figure 6). As these are the two shallowest sampled geothermal wells (with estimated temperatures of 60.8 and $72.9^{\circ} \mathrm{C}$, respectively) they fall within the range of temperatures for which microbially mediated biodegradation has been observed $\left(<75^{\circ} \mathrm{C}\right.$; Milkov, 2010).

\section{- Connectivity deep and shallow subsurface}

Shallow groundwater samples were collected near both faults and known gas accumulations, where migration of methane from the deep subsurface is most likely. However, naturally occurring thermogenic methane was only observed below the Neogene and Paleogene clay barriers that form the hydrogeological base in the Netherlands. Although no evidence for gas phase accumulations below these layers were found in this study, this suggests that these geological units form a important barrier to upward gas seepage. Their importance in controlling fluid migration is supported by the $\delta^{37} \mathrm{Cl}$ data for dissolved chloride. Given the non-reactive nature of chloride in aquatic environments, most natural waters tend to have a $\delta^{37} \mathrm{Cl}$ around $0 \%$ (Eggenkamp, 1994). However, since the diffusion coefficient of ${ }^{35} \mathrm{Cl}$ is slightly larger than that of ${ }^{37} \mathrm{Cl}$, chloride in groundwater with a lighter ${ }^{37} \mathrm{Cl} /{ }^{35} \mathrm{Cl}$ composition 
(more negative $\delta^{37} \mathrm{Cl}$ value) has been attributed to diffusion controlled transport (Beekman et al., 2011; Desaulniers et al., 1986).

In this study, a number of samples collected in the south-west of the Netherlands from Paleogene aquifers show very negative values: down to $-2.08 \%$ o (Figure 8 ). These sandy aquifers are bounded on the top and bottom by low permeable marine clays. They are recharged by fresh rain water infiltrating in neighbouring Belgium, with chloride concentrations increasing from fresh to brackish as the groundwater flows towards the north and west and into the Netherlands (Van Der Kemp et al., 2000). The negative $\delta^{37} \mathrm{Cl}$ values in these samples therefore point out that transport of solutes is dominantly controlled by diffusion from the under- and overlying clays, rather than advective transport. As chloride concentrations increase further, $\delta^{37} \mathrm{Cl}$ values increasingly resemble that of the (connate) seawater source in the confining units $(0 \%)$, resulting in the observed positive correlation between $\delta^{37} \mathrm{Cl}$ and $\mathrm{Cl}$.

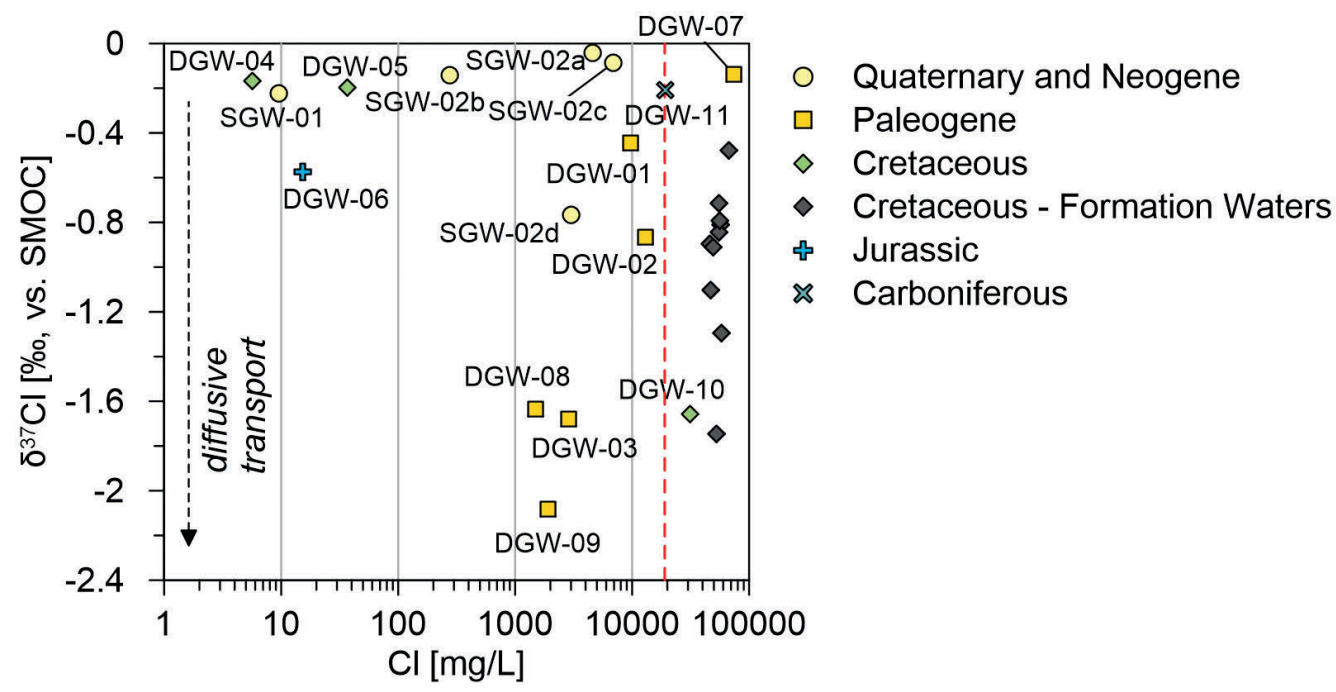

Figure $8 \mid \delta^{37} \mathrm{Cl}$ chloride stable isotope ratio versus chloride concentration (A) and versus percent Modern Carbon (B), for deep and shallow Dutch groundwater samples. Symbols show the age of the stratigraphic unit. Red dashed line is the chloride concentration of modern seawater.

This positive correlation is also observed for the Cretaceous formation waters (Figure 8). However, chloride concentrations in these aquifers exceed that of seawater. The elevated chloride concentrations result from dissolution of halite, which has a $\delta^{37} \mathrm{Cl}$ value of around 0\%o (Eggenkamp et al., 2019). Subsequent diffusive transport then leads to the observed negative $\delta^{37} \mathrm{Cl}$ values. Besides the Cretaceous samples, one of the samples from a Paleogene unit in the north eastern corner of the country (DGW-07) also fits this pattern. Here, salinities 
exceeding that of seawater were indeed shown to result from dissolution of a nearby evaporite diapir (Griffioen et al., 2016).

Radiocarbon dating shows that groundwater in the Paleogene and older aquifers contains ${ }^{14} \mathrm{C}$ well above detection limit ( $0.01-0.1 \mathrm{pMC}$, Table 3$)$ and a significant fraction of relatively recent groundwater $(<40,000$ years old) must be present. Significant fractions of modern carbon were also observed in the groundwater samples from the Jurassic, Cretaceous and Carboniferous formations. This confirms that groundwater in these formations is not stagnant, and that some recharge is happening or has happened during the past tens of thousands of years. National-scale groundwater modelling by Valstar and Goorden (2016) indeed pointed out that exchange of groundwater across the Paleogene clay layers is ongoing. However, as diffusion appears to be the dominant transport mechanism in these units, significant advective transport of dissolved thermogenic methane from below these layers to the shallow subsurface is unlikely.

Besides the presence of the Paleogene clays, the absence of thermogenic methane in shallow groundwater may also have resulted from a number of other processes that limit its upward migration. First, gas seeping upward through faults that penetrate the coarse grained sandy Quaternary aquifers, that characterize most of the Dutch shallow subsurface, would likely become unfocused and hence harder or even impossible to detect (Thielemann et al., 2000). Second, lateral groundwater flow in the aquifers encountered by the migrating gas phase may lead to significant dilution and ultimately stagnation of the upward seeping gas phase, preventing detection in overlying aquifers (Schout et al., 2020). Hence, while no evidence for methane seepage to the shallow groundwater through natural connections with the deep subsurface was encountered, its occurrence cannot be entirely excluded on the basis of this study. Nevertheless, the results of this study do indicate that future observations of thermogenic methane in shallow groundwater are most likely linked to anthropogenic activities. 


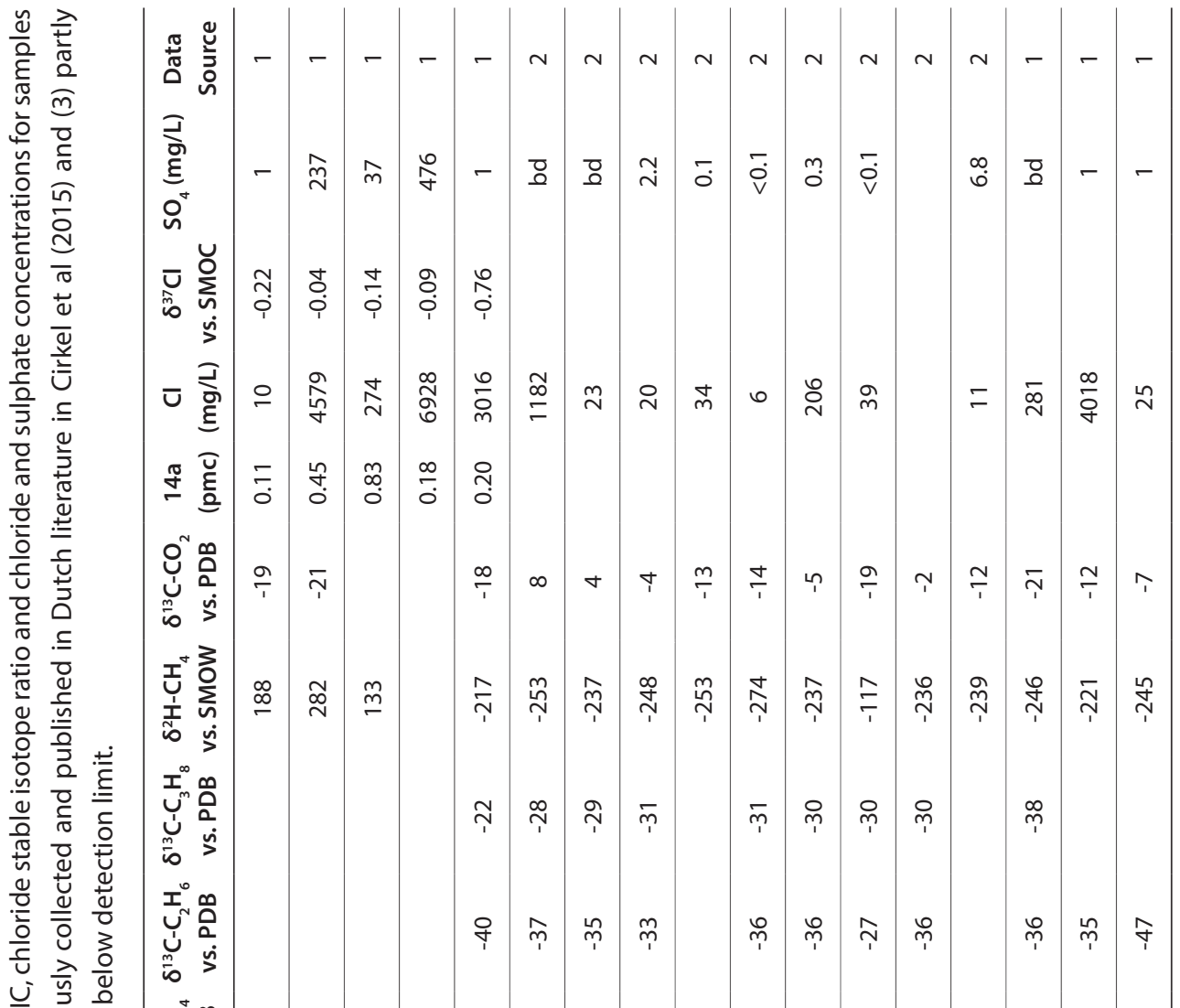

पे

نे व

ù

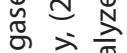

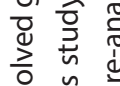

岸

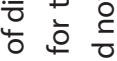

으웜

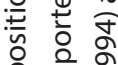

응 웡

$x^{+} \infty$

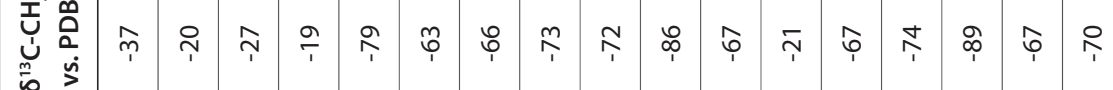

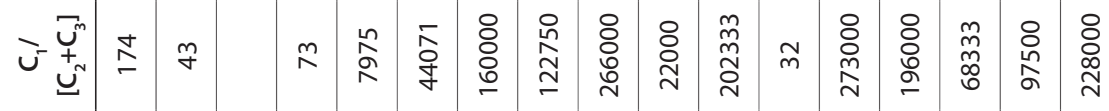

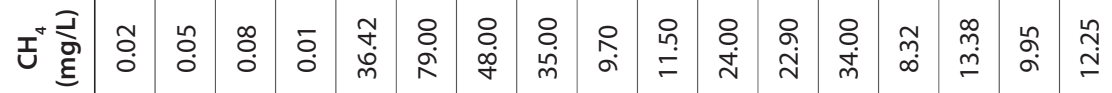

仓े $\frac{2}{3}$ है

늘

要

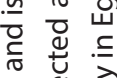

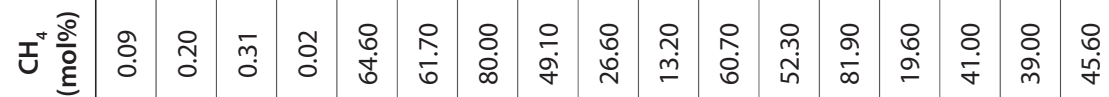

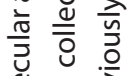

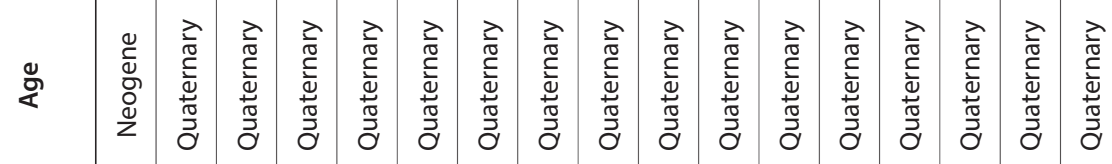

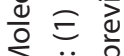

襄

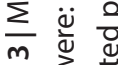

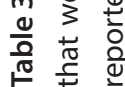

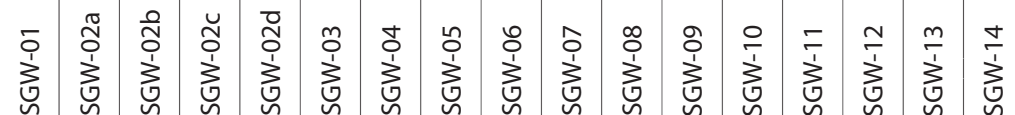




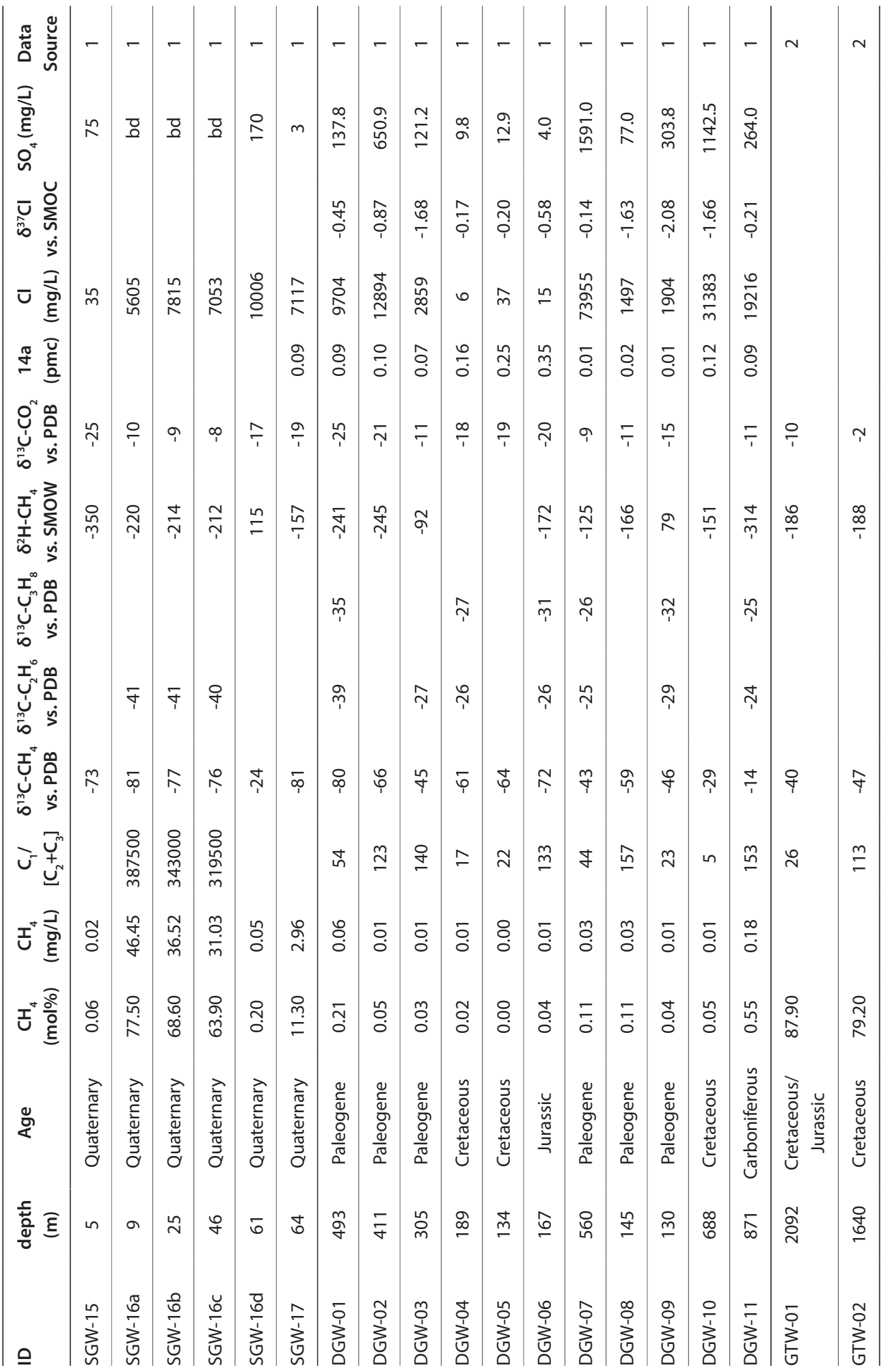




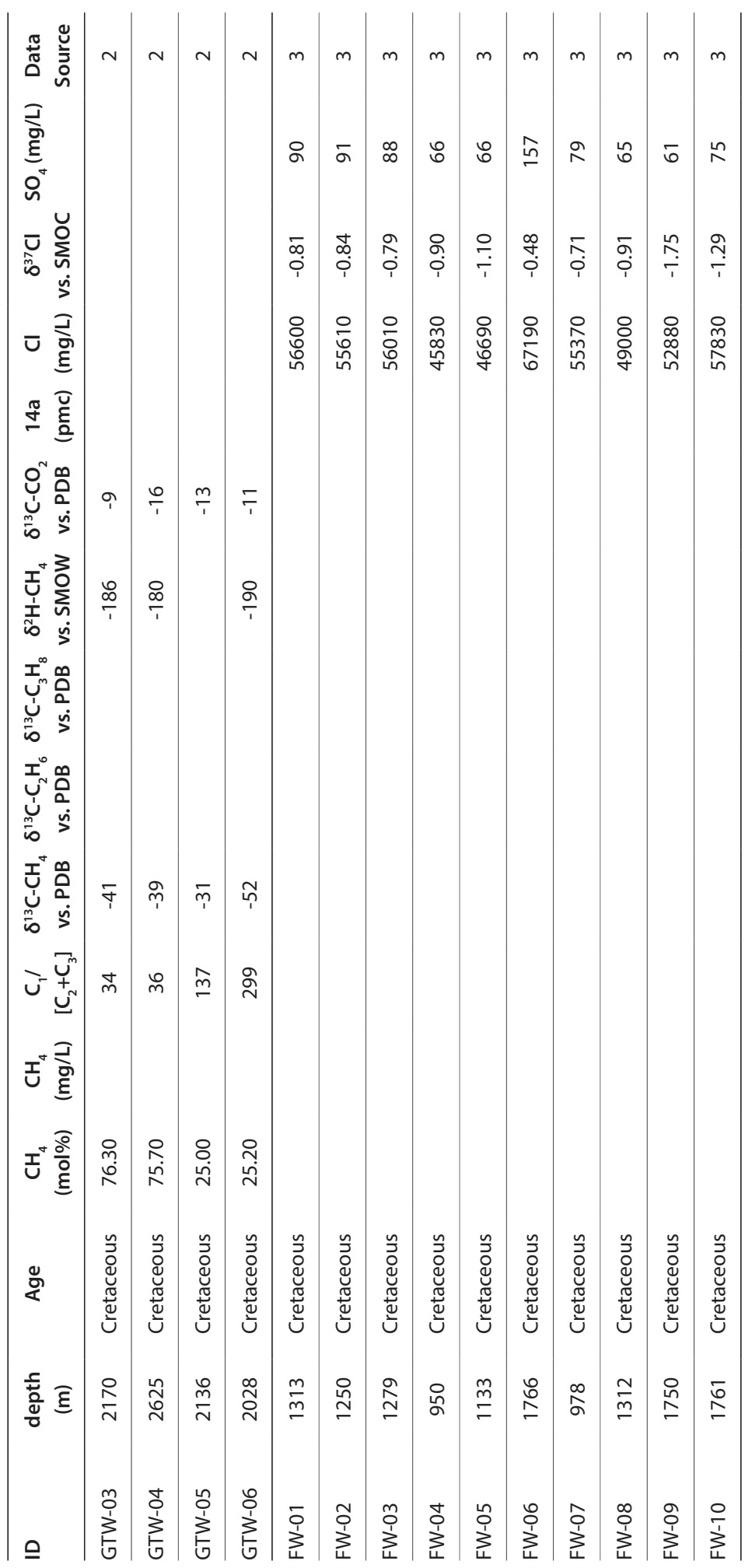




\section{$2.5 \mid$ CONCLUSIONS}

The origin and distribution of methane in the subsurface of the Netherlands was assessed based on a compiled dataset of water samples analysed for methane concentrations throughout the country $(n=12,219)$, in combination with targeted water samples collected from wells that were also analysed for the molecular and isotopic composition of dissolved gasses $(n=40)$.

The presence of methane is ubiquitous in the Quaternary groundwater system, that is hydraulically separated from deeper groundwater compartments by a succession of thick Neogene and Paleogene marine clays. Concentrations in $7.5 \%$ of samples exceed $10 \mathrm{mg} \cdot \mathrm{L}^{-1}$, and median concentrations $\left(0.2 \mathrm{mg} \cdot \mathrm{L}^{-1}\right)$ are significantly higher than those observed in neighbouring countries. The largest methane concentrations occur in the coastal provinces, where Holocene peats and marine clays overly the Quaternary aquifers. There, median concentrations reached $4.0 \mathrm{mg} \cdot \mathrm{L}^{-1}$ between 20 to $40 \mathrm{~m}$ bgs. However, at greater depths ( 100 - 160 m bgs) median methane concentrations are lower in the Holocene coastal part of the country than in inland areas, most likely because of the presence of seawater associated dissolved sulphate at these depths preventing microbial methanogenesis in buried Pleistocene aquifers. Besides these shallow Holocene formations, other prominent sources of dissolved methane in Dutch shallow groundwater were shown to be the marine Eem Formation and the glacial Peelo Formation.

Isotopic analysis of samples from the shallow groundwater system confirmed that naturally present methane has a biogenic origin, even though the samples were collected at locations where migration of thermogenic gas from the deep subsurface was deemed most likely (i.e. close to major faults and overlying gas reservoirs). $\delta \mathrm{D}-\mathrm{CH}_{4}$ of samples with methane concentrations $>1 \mathrm{mg} \cdot \mathrm{L}^{-1}$ were either around $-250 \%$ or larger, indicating that $\mathrm{CO}_{2}$ reduction rather than methyl-type fermentation is the dominant methanogenic pathway. $A$ number of samples with low biogenic methane concentrations $\left(<0.1 \mathrm{mg} . \mathrm{L}^{-1}\right)$ were severely impacted by anaerobic methane oxidation, resulting in extremely enriched $\delta \mathrm{D}-\mathrm{CH}_{4}$ values (100-300\%o) and $\delta^{13} \mathrm{C}-\mathrm{CH}_{4}$ and $\mathrm{C}_{1} /\left(\mathrm{C}_{2}+\mathrm{C}_{3}\right)$ values that resemble that of thermogenic gas. In the absence $\delta \mathrm{D}-\mathrm{CH}_{4}$ analysis, this could therefore lead to incorrect fingerprinting of methane origin.

The composition of dissolved gasses in the majority of samples from deeper groundwater wells (up to $871 \mathrm{~m}$ bgs) had a mixed isotopic signature. A clear thermogenic ethane isotopic signature in these samples confirmed that at least trace amounts of thermogenic methane are present at these depths, which shows that some upward seepage of thermogenic methane does occur. Given that thermogenic methane was not observed in the shallow groundwater above the Paleogene marine clay barriers, they are believed to play a role in constraining further upward transport of thermogenic gas. Negative $\delta^{37} \mathrm{Cl}$ values observed in the Paleogene sandy aquifers that are situated in between such clays (up to $-2.08 \%$ vs. SMOC) corroborate this conclusion, and indicate that solute transport 
into these formations is diffusion rather than advection controlled. The results of this study highlight that future observations of thermogenic methane in shallow groundwater of the Netherlands are most likely attributable to migration through anthropogenic rather than natural conduits.

\section{Acknowledgements}

This work is part of the research program 'Shale Gas and Water' with project number 859.14.001, which is financed by the Dutch Research Council (NWO). We thank the Institut de Physique du Globe de Paris for making available their laboratory facilities to enable the $\delta^{37} \mathrm{Cl}$ measurements. We thank the participating well owners for facilitating the sampling campaign. 


\section{REFERENCES}

Atkins, M.L., Santos, I.R., Maher, D.T., 2015. Groundwater methane in a potential coal seam gas extraction region. J. Hydrol. Reg. Stud. 4, 452-471. https://doi.org/10.1016/j.ejrh.2015.06.022

Beekman, H.E., Eggenkamp, H.G.M., Appelo, C.A.J., 2011. An integrated modelling approach to reconstruct complex solute transport mechanisms $-\mathrm{Cl}$ and $\delta 37 \mathrm{Cl}$ in pore water of sediments from a former brackish lagoon in The Netherlands. Appl. Geochemistry 26, 257-268. https://doi. org/10.1016/j.apgeochem.2010.11.026

Bell, R.A., Darling, W.G., Ward, R.S., Basava-Reddi, L., Halwa, L., Manamsa, K., Ó Dochartaigh, B.E., 2017. A baseline survey of dissolved methane in aquifers of Great Britain. Sci. Total Environ. 601-602, 1803-1813. https://doi.org/10.1016/j.scitotenv.2017.05.191

Bense, V.F., Van Balen, R.T., De Vries, J.J., 2003. The impact of faults on the hydrogeological conditions in the Roer Valley Rift System: An overview. Geol. en Mijnbouw/Netherlands J. Geosci. 82, 41-54. https://doi.org/10.1017/S0016774600022782

Bergen, F. van, Zijp, M., Nelskamp, S., Kombrink, H., 2013. Shale gas evaluation of the Early Jurassic Posidonia Shale Formation and the Carboniferous Epen Formation in the Netherlands, in: Chatellier, J., Jarvie, D. (Eds.), Critical Assessment of Shale Resource Plays: AAPG Memoir 103, Critical Assessment of Shale Resource Plays. AAPG Memoir 103, p. 24. https://doi. org/10.1306/134017221H53468

Bol, J., 1991. Moeras- of brongas. Grondboor en Hamer 150-153. NITG report 03-137-B.

Buijs, E.A., Stuurman, R.J., 2003. Herkomst van het brongas in Noord-Holland. Utrecht.

Christian, K.M., Lautz, L.K., Hoke, G.D., Siegel, D.I., Lu, Z., Kessler, J., 2016. Methane occurrence is associated with sodium-rich valley waters in domestic wells overlying the Marcellus shale in New York State. Water Resour. Res. 52, 206-226. https://doi.org/10.1002/2015WR017805

Cirkel, G., Hartog, N., De La, B., Gonzalez, L., Stuyfzand, P., 2015. Methaan in ondiep Nederlands grondwater: verbinding met de diepe ondergrond? $\mathrm{H} 2 \mathrm{O}$.

de Gans, W., Beets, D.J., Centineo, M.C., 2000. Late Saalian and Eemian deposits in the Amsterdam glacial basin. Netherlands J. Geosci. 79, 147-160. https://doi.org/10.1017/S0016774600021685

de Vries, J.J., 2007. Groundwater, in: Wong, T.E., Batjes, D.A.J., Jager, J. de (Eds.), Geology of the Netherlands. Royal Netherlands Academy of Arts and Sciences, Amsterdam, p. 354.

Desaulniers, D.E., Kaufmann, R.S., Cherry, J.A., Bentley, H.W., 1986. $37 \mathrm{Cl}-35 \mathrm{Cl}$ variations in a diffusioncontrolled groundwater system. Geochim. Cosmochim. Acta 50, 1757-1764. https://doi. org/10.1016/0016-7037(86)90137-7

Dufour, F.C., 1998. Groundwater in the Netherlands: invisible water on which we walk. TNO Geological Survey of the Netherlands, Delft.

Eggenkamp, H., 1994. $\delta 37 \mathrm{Cl}$ : the geochemistry of chlorine isotopes. PhD thesis. Utrecht University.

Eggenkamp, H.G.M., Louvat, P., Griffioen, J., Agrinier, P., 2019. Chlorine and bromine isotope evolution within a fully developed Upper Permian natural salt sequence. Geochim. Cosmochim. Acta 245, 316-326. https://doi.org/10.1016/j.gca.2018.11.010

Eltschlager, K.K., Hawkins, J.W., Ehler, W.C., Baldassare, F.J., 2001. Technical Measures for the Investigation and Mitigation of Fugitive Methane Hazards in Areas of Coal Mining. U.S. Dep. Inter. Off. Surf. Min. 129 pp. 
Etiope, G., Baciu, C.L., Schoell, M., 2011. Extreme methane deuterium, nitrogen and helium enrichment in natural gas from the Homorod seep (Romania). Chem. Geol. 280, 89-96. https://doi. org/10.1016/j.chemgeo.2010.10.019

Etiope, G., Feyzullayev, A., Baciu, C.L., 2009. Terrestrial methane seeps and mud volcanoes: A global perspective of gas origin. Mar. Pet. Geol. 26, 333-344.

Etiope, G., lonescu, A., 2015. Low-temperature catalytic CO2 hydrogenation with geological quantities of ruthenium: A possible abiotic $\mathrm{CH} 4$ source in chromitite-rich serpentinized rocks. Geofluids 15, 438-452. https://doi.org/10.1111/gfl.12106

Forde, O.N., Cahill, A.G., Mayer, K.U., Mayer, B., Simister, R.L., Finke, N., Crowe, S.A., Cherry, J.A., Parker, B.L., 2019. Hydro-biogeochemical impacts of fugitive methane on a shallow unconfined aquifer. Sci. Total Environ. https://doi.org/10.1016/j.scitotenv.2019.06.322

Fortuin, N.P.M., Willemsen, A., 2005. Exsolution of nitrogen and argon by methanogenesis in Dutch ground water. J. Hydrol. 301, 1-13.

Griffioen, J., Klaver, G., Westerhoff, W.E., 2016. The mineralogy of suspended matter, fresh and Cenozoic sediments in the fluvio-deltaic Rhine-Meuse-Scheldt-Ems area, the Netherlands: An overview and review. Netherlands J. Geosci. 95, 23-107. https://doi.org/10.1017/njg.2015.32

Griffioen, J., Vermooten, S., Janssen, G., 2013. Geochemical and palaeohydrological controls on the composition of shallow groundwater in the Netherlands. Appl. Geochemistry 39, 129-149. https://doi.org/10.1016/j.apgeochem.2013.10.005

Griffioen, Jasper, Verweij, H., Stuurman, R., 2016. The composition of groundwater in Palaeogene and older formations in the Netherlands. A synthesis. Netherlands J. Geosci. 95, 349-372. https:// doi.org/10.1017/njg.2016.19

Humez, P., Mayer, B., Ing, J., Nightingale, M., Becker, V., Kingston, A., Akbilgic, O., Taylor, S., 2016. Occurrence and origin of methane in groundwater in Alberta (Canada): Gas geochemical and isotopic approaches. Sci. Total Environ. 541, 1253-1268. https://doi.org/10.1016/j.scitotenv.2015.09.055

Jackson, R.B., Vengosh, A., Carey, J.W., Davies, R.J., Darrah, T.H., Sullivan, F.O., Gabrielle, P., 2014. The Environmental Costs and Benefits of Fracking. Annu. Rev. Environ. Resour. 39, 327-362. https:// doi.org/10.1146/annurev-environ-031113-144051

Jackson, R.B., Vengosh, A., Darrah, T.H., Warner, N.R., Down, A., Poreda, R.J., Osborn, S.G., Zhao, K., Karr, J.D., 2013. Increased stray gas abundance in a subset of drinking water wells near Marcellus shale gas extraction. Proc. Natl. Acad. Sci. 110, 11250-11255. https://doi.org/10.1073/ pnas. 1221635110

Jager, J. de, Geluk, M.C., 2007. Petroleum Geology, in:Wong, T.E., Batjes, D.A.J., Jager, J. de (Eds.), Geology of the Netherlands. Royal Netherlands Academy of Arts and Sciences, pp. 241-264.

Kang, M., Kanno, C.M., Reid, M.C., Zhang, X., Mauzerall, D.L., Celia, M.A., Chen, Y., Onstott, T.C., 2014. Direct measurements of methane emissions from abandoned oil and gas wells in Pennsylvania. Proc. Natl. Acad. Sci. 111, 18173-18177. https://doi.org/10.1073/pnas.1408315111

Kulongoski, J.T., McMahon, P.B., Land, M., Wright, M.T., Johnson, T.A., Landon, M.K., 2018. Origin of Methane and Sources of High Concentrations in Los Angeles Groundwater. J. Geophys. Res. Biogeosciences 123, 818-831. https://doi.org/10.1002/2017JG004026

Laier, T., Jørgensen, N.O., Buchardt, B., Cederberg, T., Kuijpers, A., 1992. Accumulation and seepages of biogenic gas in northern Denmark. Cont. ShelfRes. 12,1173-1186. https://doi.org/10.1016/02784343(92)90077-W 
Lollar, B.S., Lacrampe-Couloume, G., Slater, G.F., Ward, J., Moser, D.P., Gihring, T.M., Lin, L.H., Onstott, T.C., 2006. Unravelling abiogenic and biogenic sources of methane in the Earth's deep subsurface. Chem. Geol. 226, 328-339. https://doi.org/10.1016/j.chemgeo.2005.09.027

McIntosh, J.C., Hamilton, S.M., Grasby, S.E., Osborn, S.G., 2014. Origin, distribution and hydrogeochemical controls on methane occurrences in shallow aquifers, southwestern Ontario. Appl. Geochemistry 50, 37-52. https://doi.org/10.1016/j.apgeochem.2014.08.001

McMahon, P.B., Belitz, K., Barlow, J.R.B., Jurgens, B.C., 2017. Methane in aquifers used for public supply in the United States. Appl. Geochemistry 84, 337-347. https://doi.org/10.1016/j. apgeochem.2017.07.014

Meinardi, C.R., 1994. Groundwater recharge and travel times in the sandy regions of the Netherlands. $\mathrm{PhD}$ thesis. VU University Amsterdam.

Mendizabal, I., Stuyfzand, P.J., Wiersma, A.P., 2011. Hydrochemical system analysis of public supply well fields, to reveal water-quality patterns and define groundwater bodies: The Netherlands. Hydrogeol. J. 19, 83-100. https://doi.org/10.1007/s10040-010-0614-0

Milkov, A. V., 2010. Methanogenic biodegradation of petroleum in the West Siberian Basin (Russia): Significance for formation of giant Cenomanian gas pools. Am. Assoc. Pet. Geol. Bull. 94, 14851541. https://doi.org/10.1306/01051009122

Milkov, A. V., Etiope, G., 2018. Revised genetic diagrams for natural gases based on a global dataset of $>20,000$ samples. Org. Geochem. 125, 109-120. https://doi.org/10.1016/j. orggeochem.2018.09.002

Ministry for Infrastructure and Environment, Ministry for Econimic Affairs and Climate, 2018. Structuurvisie Ondergrond. Den Haag, Netherlands.

Miyazaki, B., 2009. Well integrity: An overlooked source of risk and liability for underground natural gas storage. Lessons learned from incidents in the USA: Figure 1. Geol. Soc. London, Spec. Publ. 313, 163-172. https://doi.org/10.1144/sp313.11

Molofsky, L.J., Connor, J. a, Farhat, S.K., Jr, A.S.W., 2011. Methane in Pennsylvania water wells unrelated to Marcellus shale fracturing. Oil Gas J. December 5, 54-67.

Molofsky, L.J., Connor, J.A., Wylie, A.S., Wagner, T., Farhat, S.K., 2013. Evaluation of Methane Sources in Groundwater in Northeastern Pennsylvania. Groundwater 51, 333-349.

Molofsky, L.J., Richardson, S.D., Gorody, A.W., Baldassare, F., Black, J.A., McHugh, T.E., Connor, J.A., 2016. Effect of Different Sampling Methodologies on Measured Methane Concentrations in Groundwater Samples. Groundwater 54, 669-680. https://doi.org/10.1111/gwat.12415

Molofsky, L.J., Richardson, S.D., Gorody, A.W., Baldassare, F., Connor, J.A., McHugh, T.E., Smith, A.P., Wylie, A.S., Wagner, T., 2018. Purging and other sampling variables affecting dissolved methane concentration in water supply wells. Sci. Total Environ. 618, 998-1007. https://doi.org/10.1016/j. scitotenv.2017.09.077

Mook, W.G., Plicht, J.Van Der, 1999. Reporting Radiocarbon Activities and Concentrations. Radiocarbon 41, 227-239.

Nicot, J.P., Larson, T., Darvari, R., Mickler, P., Slotten, M., Aldridge, J., Uhlman, K., Costley, R., 2017. Controls on Methane Occurrences in Shallow Aquifers Overlying the Haynesville Shale Gas Field, East Texas. Groundwater 55, 443-454. https://doi.org/10.1111/gwat.12500 
Nisbet, E.G., Manning, M.R., Dlugokencky, E.J., Fisher, R.E., Lowry, D., Michel, S.E., Myhre, C.L., Platt, S.M., Allen, G., Bousquet, P., Brownlow, R., Cain, M., France, J.L., Hermansen, O., Hossaini, R., Jones, A.E., Levin, I., Manning, A.C., Myhre, G., Pyle, J.A., Vaughn, B.H., Warwick, N.J., White, J.W.C., 2019. Very Strong Atmospheric Methane Growth in the 4 Years 2014-2017: Implications for the Paris Agreement. Global Biogeochem. Cycles 33, 318-342. https://doi.org/10.1029/2018GB006009

NLOG, 2020. Netherlands Oil and Gas Portal [WWW Document]. URL https://www.nlog.nl/ (accessed 1.2.20).

Osborn, S.G., Vengosh, A., Warner, N.R., Jackson, R.B., 2011. Methane contamination of drinking water accompanying gas-well drilling and hydraulic fracturing. Proc. Natl. Acad. Sci. 108, E665-E666. https://doi.org/https://doi.org/10.1073/pnas.1100682108

Rice, A.K., Lackey, G., Proctor, J., Singha, K., 2018. Groundwater-quality hazards of methane leakage from hydrocarbon wells: A review of observational and numerical studies and four testable hypotheses. Wiley Interdiscip. Rev. Water e1283. https://doi.org/10.1002/wat2.1283

Schloemer, S., Elbracht, J., Blumenberg, M., Illing, C.J., 2016. Distribution and origin of dissolved methane, ethane and propane in shallow groundwater of Lower Saxony, Germany. Appl. Geochemistry 67, 118-132. https://doi.org/10.1016/j.apgeochem.2016.02.005

Schout, G., Griffioen, J., Hassanizadeh, S.M., Cardon de Lichtbuer, G., Hartog, N., 2019. Occurrence and fate of methane leakage from cut and buried abandoned gas wells in the Netherlands. Sci. Total Environ. 659, 773-782. https://doi.org/10.1016/j.scitotenv.2018.12.339

Schout, G., Hartog, N., Hassanizadeh, S.M., Griffioen, J., 2017. Impact of an historic underground gas well blowout on the current methane chemistry in a shallow groundwater system. Proc. Natl. Acad. Sci. U. S. A. 115, 296-301. https://doi.org/10.1073/pnas.1711472115

Schout, G., Hartog, N., Hassanizadeh, S.M., Helmig, R., Griffioen, J., 2020. Impact of groundwater flow on methane gas migration and retention in unconsolidated aquifers. J. Contam. Hydrol. https:// doi.org/10.1016/j.jconhyd.2020.103619

Schroot, B.M., Klaver, G.T., Schüttenhelm, R.T.E., 2005. Surface and subsurface expressions of gas seepage to the seabed - Examples from the Southern North Sea. Mar. Pet. Geol. 22, 499-515. https://doi.org/10.1016/j.marpetgeo.2004.08.007

Siegel, D.I., Azzolina, N.A., Smith, B.J., Perry, A.E., Bothun, R.L., 2015. Methane concentrations in water wells unrelated to proximity to existing oil and gas wells in northeastern Pennsylvania. Environ. Sci. Technol. 49, 4106-4112. https://doi.org/10.1021/es505775c

Sissingh, W., 2004. Palaeozoic and Mesozoic igneous activity in the Netherlands: A tectonomagmatic review. Geol. en Mijnbouw/Netherlands J. Geosci. 83, 113-134. https://doi.org/10.1017/ S0016774600020084

SodM, 2019. De integriteit van onshore putten in Nederland. State Supervision of Mines. Den Haag.

Stuyfzand, P.J., Luers, F., Reijnen, G.K., 1994. Geohydrochemische aspecten van methaan in grondwater in Nederland. $\mathrm{H} 2 \mathrm{O}$.

ten Veen, J.H., van Gessel, S.F., den Dulk, M., 2012. Thin- and thick-skinned salt tectonics in the Netherlands; a quantitative approach. Netherlands J. Geosci. - Geol. en Mijnb. 91, 447-464. https://doi.org/10.1017/S0016774600000330

Ten Veen, J.H., Verweij, H., Donders, T., Geel, K., de Bruin, G., Munsterman, D., Verreussel, R., Daza Cajigal, V., Harding, R., Cremer, H., 2013. Anatomy of the Cenozoic Eridanos Hydrocarbon System. TNO report $2013 \mathrm{R} 10060$. Utrecht. 
Thielemann, T., Lücke, A., Schleser, G.H., Littke, R., 2000. Methane exchange between coal-bearing basins and the atmosphere: The Ruhr Basin and the Lower Rhine Embayment, Germany. Org. Geochem. 31, 1387-1408. https://doi.org/10.1016/S0146-6380(00)00104-2

TNO, 2018. Inventarisatie aantoonbare effecten voor mens en milieu als gevolg van historische conventionele frackoperaties. TNO report 2018 R10807. Utrecht.

Valstar, J.R., Goorden, N., 2016. Far-field transport modelling for a repository in the Boom Clay in the Netherlands. Geol. en Mijnbouw/Netherlands J. Geosci. 95, 337-347. https://doi.org/10.1017/ njg.2016.13

Van Der Kemp, W.J.M., Appelo, C.A.J., Walraevens, K., 2000. Inverse chemical modeling and radiocarbon dating of palaeogroundwaters: The Tertiary Ledo-Paniselian aquifer in Flanders, Belgium. Water Resour. Res. 36, 1277-1287. https://doi.org/10.1029/1999WR900357

van Thienen-Visser, K., Breunese, J.N., 2015. Induced seismicity of the Groningen gas field: History and recent developments. Lead. Edge 34, 664-671. https://doi.org/10.1190/tle34060664.1

Vengosh, A., Jackson, R.B., Warner, N., Darrah, T.H., Kondash, A., 2014. A Critical Review of the Risks to Water Resources from Unconventional Shale Gas Development and Hydraulic Fracturing in the United States. Environ. Sci. Technol. 48, 8334-8348. https://doi.org/10.1021/es405118y

Verhoef, E., Neeft, E., Grupa, J., Poley, A., 2014. Outline of a disposal concept in clay. COVRA, report no. OPERA-PG-COV008.

Verweij, J.M., Nelskamp, S.N., Ten Veen, J.H., De Bruin, G., Geel, K., Donders, T.H., 2018. Generation, migration, entrapment and leakage of microbial gas in the Dutch part of the Southern North Sea Delta. Mar. Pet. Geol. 97, 493-516. https://doi.org/10.1016/j.marpetgeo.2018.07.034

Verweij, J.M., Simmelink, H.J., Underschultz, J., Witmans, N., 2012. Pressure and fluid dynamic characterisation of the Dutch subsurface. Geol. en Mijnbouw/Netherlands J. Geosci. 91, 465490. https://doi.org/10.1017/S0016774600000342

Warner, N.R., Jackson, R.B., Darrah, T.H., Osborn, S.G., Down, A., Zhao, K., White, A., Vengosh, A., 2012. Geochemical evidence for possible natural migration of Marcellus Formation brine to shallow aquifers in Pennsylvania. Proc. Natl. Acad. Sci. U. S. A. 109, 11961-11966.

Whiticar, M.J., 1999. Carbon and hydrogen isotope systematics of bacterial formation and oxidation of methane. Chem. Geol. 161, 291-314. https://doi.org/10.1016/s0009-2541(99)00092-3

Williams, G.M., Aitkenhead, N., 1991. Lessons from Loscoe: the uncontrolled migration of landfill gas. Q. J. Eng. Geol. Hydrogeol. 24, 191-207. https://doi.org/10.1144/GSL.QJEG.1991.024.02.03 


\section{APPENDIX}

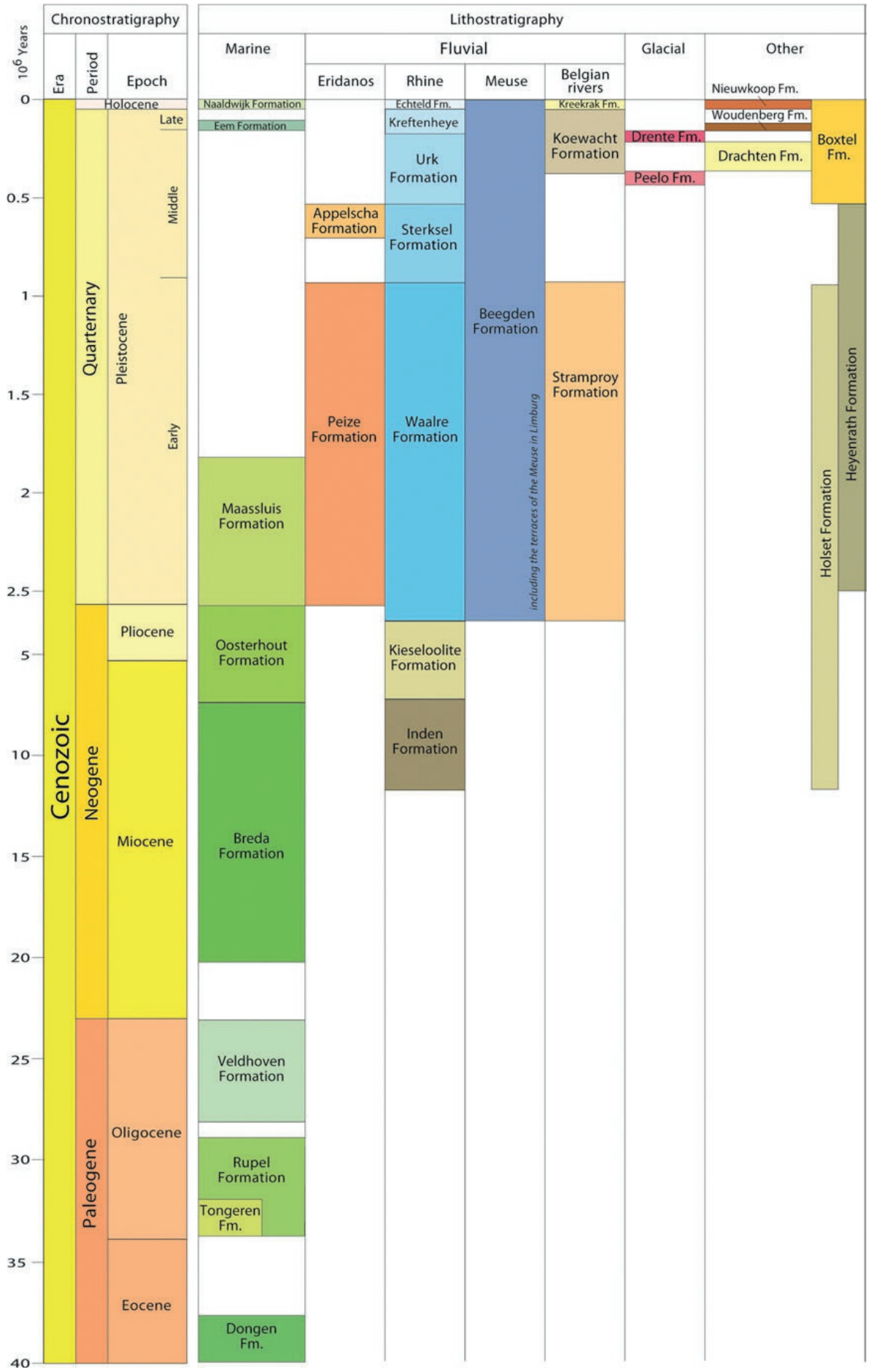

Figure S1 | Lithostratigraphy of Cenozoic deposits in the Netherlands. Taken from J. Griffioen et al., 2016. 


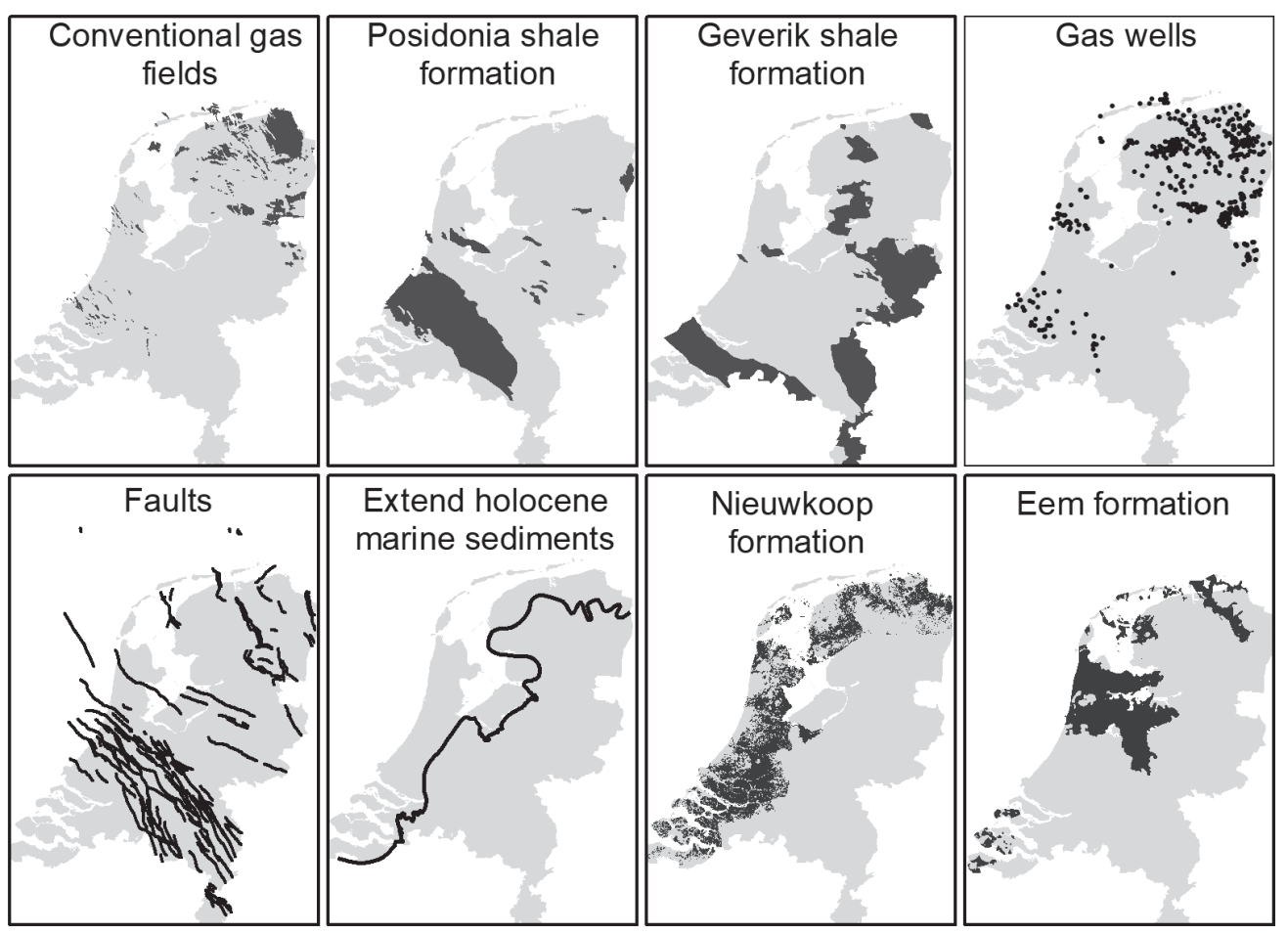

Figure S2 | Spatial features used for the statistical analysis of methane concentrations described in section 4.1.4. Surface area of conventional reservoirs, shale formations and gas wells obtained from the Netherland Oil and Gas Portal (www.NLOG.nl). Surface area of Nieuwkoop Formation, Eem Formation, and location of faults obtained from the Geological Survey of the Netherlands (www.dinoloket.nl). Extent of Holocene marine sediments derived from Griffioen et al. (2013), and area west and north of the line is referred to as the coastal lowlands. 


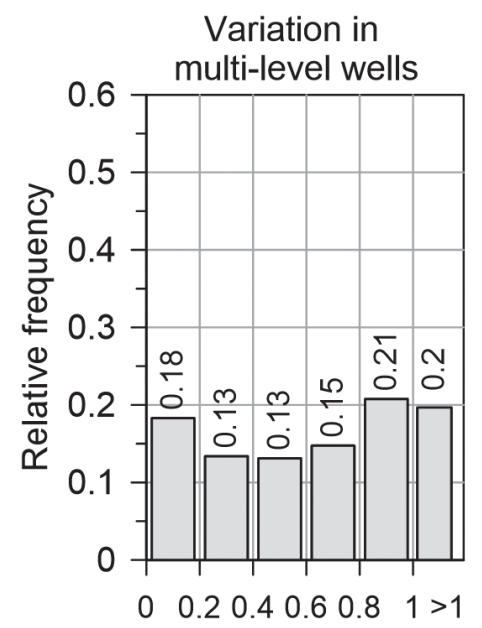

Coefficient of variation
Figure S3 | Relative frequency histogram of the within well coefficient of variation (CV) of methane concentrations in multi-level monitoring wells with at least multiple sampled well screens. Only well screens with average methane concentrations $>0.01 \mathrm{mg} \cdot \mathrm{L}^{-1}$ were considered. 
Table S1 | Gas composition from onshore deep wells in the Netherlands tested in Paleogene or younger formations. Data from (NLOG, 2020).

\begin{tabular}{lccccccc}
\hline Well ID & Formation & $\begin{array}{c}\mathrm{CH}_{4} \\
(\mathrm{~mol} \%)\end{array}$ & $\begin{array}{c}\mathrm{C}_{2} \mathrm{H}_{6} \\
(\mathrm{~mol} \%)\end{array}$ & $\begin{array}{c}\mathrm{C}_{3} \mathrm{H}_{8} \\
(\mathrm{~mol} \%)\end{array}$ & $\begin{array}{c}\mathrm{CO}_{2} \\
(\mathrm{~mol} \%)\end{array}$ & $\begin{array}{c}\mathrm{N}_{2} \\
(\mathrm{~mol} \%)\end{array}$ & $\begin{array}{c}\mathrm{C}_{1} / \\
{\left[\mathrm{C}_{2}+\mathrm{C}_{3}\right]}\end{array}$ \\
\hline WYK-01 & Basal Dongen Tuffite & 88.63 & 0.19 & 0.02 & 0 & 11.15 & 522 \\
\hline WAV-09 & Basal Dongen Tuffite & 89.09 & 0.14 & 0.01 & 0.01 & 10.75 & 594 \\
\hline IJS-01 & Basal Dongen Tuffite & 96.5 & 0.04 & 0.01 & 0.1 & 3.3 & 1930 \\
\hline
\end{tabular}




\title{
CHAPTER
}

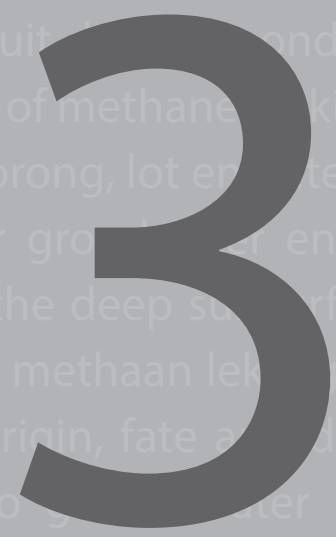

\section{Occurrence and fate of methane leakage from cut and buried abandoned gas wells in the Netherlands}

\author{
Gilian Schout \\ Jasper Griffioen \\ S. Majid Hassanizadeh \\ Guillaume C. de Lichtbuer \\ Niels Hartog
}




\section{Graphical Abstract}

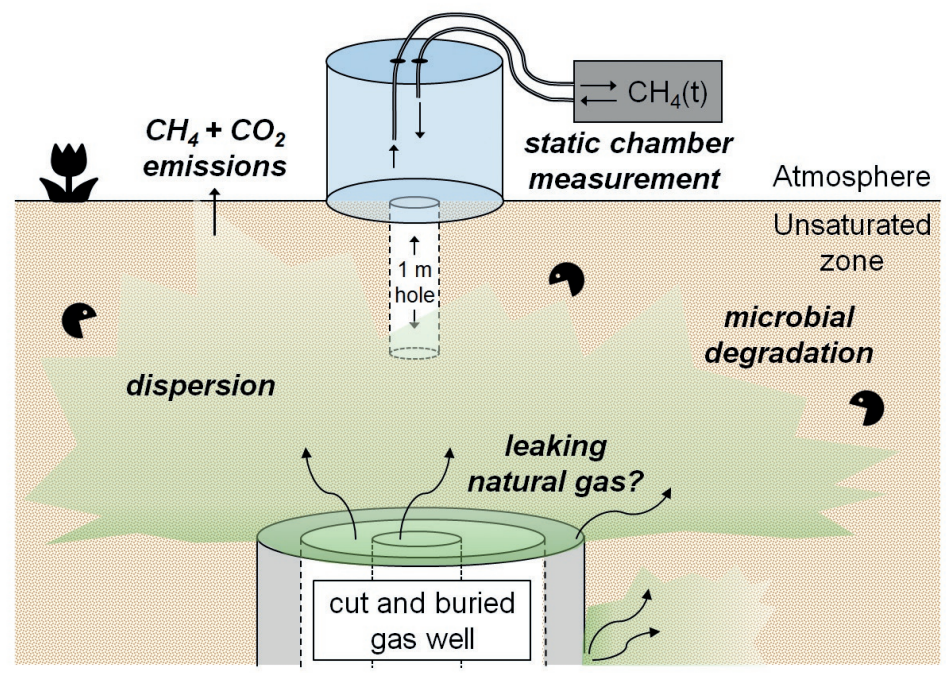

\section{ABSTRACT}

Methane leakage caused by well integrity failure was assessed at 28 abandoned gas wells and 1 oil well in the Netherlands, which have been plugged, cut and buried to below the ground surface ( $\geq 3 \mathrm{mbgl}$ ). At each location, methane concentrations were thoroughly scanned at the surface. A static chamber setup was used to measure methane flow rates from the surface as well as from $1 \mathrm{~m}$ deep holes drilled using a hand auger. An anomalously high flow rate from $1 \mathrm{~m}$ depth combined with isotopic confirmation of a thermogenic origin revealed ongoing leakage at 1 of the 29 wells (3.4\%), that had gone undetected by surficial measurements. Gas fluxes at the other sites were due to shallow production of biogenic methane. Detailed investigation at the leaking well (MON-02), consisting of 28 flux measurements conducted in a $2 \times 2 \mathrm{~m}$ grid from holes drilled to 1 and $2 \mathrm{~m}$ depth, showed that flux magnitude was spatially heterogeneous and consistently larger at $2 \mathrm{~m}$ depth compared to $1 \mathrm{~m}$. Isotopic evidence revealed oxidation accounted for roughly $25 \%$ of the decrease in flux towards the surface. The estimated total flux from the well $\left(443 \mathrm{~g} \mathrm{CH}_{4} \mathrm{hr}^{-1}\right)$ was calculated by extrapolation of the individual flow rate measurements at $2 \mathrm{~m}$ depth and should be considered an indicative value as the validity of the estimate using our approach requires confirmation by modelling and/or experimental studies. Together, our findings show that total methane emissions from leaking gas wells in the Netherlands are likely negligible compared to other sources of anthropogenic methane emissions (e.g. $<1 \%$ of emissions from the Dutch energy sector). Furthermore, subsurface measurements greatly improve the likelihood of detecting leakage at buried abandoned wells and are therefore essential to accurately assess their greenhouse gas emissions and explosion hazards. 


\section{1 | INTRODUCTION}

Leakage of natural gas from oil and gas wells has been identified as an environmental hazard for several decades (Dusseault et al., 2000; Erno and Schmitz, 1996; Harrison, 1983). Not only does leakage from oil and gas infrastructure appear to contribute significantly to rising anthropogenic methane emissions and the associated greenhouse effect (Miller et al., 2013; Rice et al., 2016), gas migrating into surrounding geological strata adversely impacts groundwater in aquifers overlying oil and gas reservoirs (Harrison, 1983; Kelly et al., 1985) and may pose an explosion hazard (Chilingar and Endres, 2005). In recent years, elevated levels of thermogenic methane in groundwater have also been attributed to wellbore leakage from newer, unconventional oil and gas wells (Darrah et al., 2014; Sherwood et al., 2016). Although water containing methane is not considered a health hazard (Vidic et al., 2013), the introduction of methane in a groundwater system may result in changing redox conditions that in turn may lead to water quality changes, such as increased sulfide concentrations (Gorody, 2012) or the mobilization of trace elements (Cahill et al., 2017).

Recent conservative estimates suggest that at least four million onshore hydrocarbon wells have been drilled worldwide (Davies et al., 2014). A well may leak if a conduit for fluid migration exists from the wellbore system to its surroundings, a situation that is referred to as well integrity failure (King and King, 2013). Whether leakage to outside the well occurs depends on the presence of a driving force. This explains why buoyancy driven gas leakage is a more common observation than leakage of liquids (Davies et al., 2014) and that the leakage risk appears to be higher for gas wells than for oil wells (King and King, 2013). Other attributes that play a role in determining leakage frequency are differences in well type (conventional versus unconventional), geographic location, well age (Ingraffea et al., 2014), well depth (Watson and Bachu, 2009), and plugging status (Kang et al., 2016). Hence, observed failure frequencies vary greatly between different basins, with reported values ranging from $1.9 \%$ to up to $75 \%$ (Davies et al., 2014).

In addition to these well attributes, observed leakage frequencies may also differ as a result of the monitoring method used. Detection and quantification of gas leakage caused by well integrity failure is typically assessed at the wellhead using measurements of either sustained casing pressure (SCP) (Brufatto et al., 2003; Lackey et al., 2017), surface casing vent flow (SCVF) (Dusseault et al., 2014; Watson and Bachu, 2009) or visual observation of leaking gas bubbles. Furthermore, gas leakage from oil and gas wells has also been assessed by measuring the concentration and isotopic composition of dissolved gasses in nearby groundwater wells (e.g. Osborn et al., 2011; Van Stempvoort and Jaworski, 1995). However, the ability to detect leakage using ground water monitoring strongly depends on the distance between the leakage point and the groundwater sampling location (Jackson et al., 2013; Molofsky et al., 2011), the direction and velocity of groundwater flow and the occurrence of microbial methane oxidation (Schout et al., 2017; Van Stempvoort et al., 2005).

At abandoned oil and gas wells, monitoring options are often limited by the lack of an intact wellhead. With the number of abandoned wells growing rapidly (Dusseault et al., 2014), 
effective monitoring at these wells will be crucial to identify and remedy methane leakage. At 88 abandoned oil and gas wells in Pennsylvania, USA, methane flow could be measured by sealing a chamber over the remainder of abandoned wellbore systems protruding from the surface (Kang et al., 2016). 90\% of these wells were a positive source of methane, with gas wells and unplugged wells emitting relatively large amounts of methane compared to oil wells and plugged wells. Besides plugging, some oil and gas jurisdictions require that wells are cut to below the ground surface and buried as the final step in the abandonment process (Davies et al., 2014). At such wells, detecting and quantifying a gas leak at surface is complicated as it originates from an uncertain depth below the surface.

Methane flow rates at 138 abandoned wells from four US states were measured by Townsend-Small et al. (2016), including a subset of wells that had been cut and buried. To measure leakage at these locations, the surface above the well sites was first scanned using mobile methane detection instruments. When anomalous concentrations were detected, methane fluxes at the soil-atmosphere interface were measured using flux chamber methodology and gas samples were collected for source identification. Overall, the study showed that $42 \%$ of unplugged wells compared to only $0.8 \%$ of plugged wells were a positive source of methane. Boothroyd et al. (2016) measured methane concentrations at the soil-atmosphere interface above 102 plugged, cut and buried wells that had been decommissioned according to best practice in the UK. By comparing the measured concentrations to that at nearby control locations, ongoing leakage caused by well integrity failure was concluded for $30 \%$ of these wells. However, the wells being the actual source of the methane was not corroborated by gas sampling and isotopic analysis. In addition, gas leaking from cut and buried wells has to migrate upward through the vadose zone by diffusion and buoyancy, where it is dispersed and may be partially oxidized before it can be detected at the surface (Erno and Schmitz, 1996). Furthermore, preferential flow paths may cause leaking gas to emerge offset with a considerable distance $(>10 \mathrm{~m}$ ) from a leaking wellbore (Forde et al. 2019).

Overall, both the environmental hazard of gas leakage at cut and buried wells and the complexities of detecting and quantifying such leakage have been understudied. So far, studies on methane leakage at cut and buried abandoned gas wells did not account for the possibility that significant portions of leaking gas may be dispersed and oxidized in the vadose zone, which could have led to an underestimation of the actual occurrence and leakage rate. In the Netherlands, there are currently roughly 900 onshore oil and gas wells that have already been abandoned (Table 1) and the effectiveness of past and present abandonment procedures is largely unknown. Therefore, we selected 29 plugged, cut and buried wells for field investigation into the occurrence of gas leakage at these sites and to assess the importance of gas dispersion and oxidation in the vadose zone using static flux measurements above holes drilled into the surface, in addition to methane flux measurements and thorough concentration scanning at the surface. The aims of the study were to evaluate (1) the potential methane leakage from abandoned wells in the Netherlands and (2) the 
suitability of various methods for detecting and quantifying gas migration from abandoned wells that have been cut and buried to below the ground surface.

\section{2 | MATERIALS AND METHODS}

\subsubsection{Oil and Gas wells in the Netherlands}

The Netherlands has a long history of oil and gas production, and has been one of the major hydrocarbon producing countries in Europe. It owes this mainly to the discovery of two large reservoirs: the Schoonebeek oil field in 1943 and the Groningen gas field in 1959. In combination with the discovery of numerous smaller fields, this has led to the drilling of around 2500 hydrocarbon wells, of which more than 1700 onshore (Table 1). Gas production and drilling of new onshore wells in the Netherlands has slowed down in recent decades, because of depletion of reserves and induced seismicity in the Groningen area (van Thienen-Visser and Breunese, 2015). Currently, around $85 \%$ of all onshore oil wells and $20 \%$ of onshore gas wells have already been abandoned (Table 1). The Dutch mining law regulates abandonment procedures of oil and gas wells. Besides prescribing detailed plugging procedures (Van Der Kuip et al., 2011), it also mandates that onshore wells are cut to at least three meter below the surface and buried ( 6 meter below the seafloor for offshore wells). While this law does not prescribe any post-abandonment monitoring, operators still carry responsibility for the well according to Dutch civil law, should any deviation from the abandonment regulations be uncovered later (i.e., if leakage is detected) (Ministry of Economic Affairs, 2017).

Table 1 | Breakdown of oil and gas well status in the Netherlands (NLOG, 2018).

\begin{tabular}{lccccc}
\hline \hline & Active & Closed-in & Plugged/ abandoned & Other/ unknown & Total \\
\hline onshore - oil & 29 & 64 & 706 & 27 & 826 \\
\hline offshore - oil & 24 & 16 & 97 & 12 & 149 \\
\hline onshore - gas & 439 & 212 & 191 & 64 & 906 \\
\hline offshore - gas & 179 & 105 & 270 & 55 & 609 \\
\hline Total & 671 & 397 & 1264 & 158 & 2490 \\
\hline
\end{tabular}

Publicly available well integrity data from Dutch wells is limited. A 2011 assessment carried out by the State Supervision of Mines (SodM) uncovered well barrier failure in 1 out of 26 production wells and 3 out of 5 water injection wells for produced water (Vignes, 2011). However, well barrier failure does not necessarily equate to well integrity failure (King and King, 2013), given that there are often multiple barriers in place (e.g. several layers of casing and cement). Hence, the risk that these wells pose collectively for both groundwater quality 
and anthropogenic GHG emissions is unknown. Recently, ongoing gas leakage was detected at one borehole where a catastrophic blowout occurred while drilling this well in 1965, and as such it was not abandoned according to protocol (Schout et al., 2017). Thus far, this is the only known instance of methane leakage to groundwater in the Netherlands.

\subsubsection{Well selection}

Hydrocarbon well locations and other meta-data were obtained from the governmental 'Netherlands Oil and Gas Portal' (NLOG, 2018). Gas wells were prioritized over oil wells. No differentiation is made in the database between wells that have only been plugged and those that also have been cut and buried. Hence, a subset of such wells was identified by visual inspection of satellite imagery, at which point accessibility for fieldwork was also estimated. For example, locations that were built over already could not be included. Wells were selected from the various gas reservoirs spread throughout the Netherlands. Finally, as most abandoned well locations are situated on private land, accessibility depended on obtaining permission from the landowner during fieldwork. Ultimately, measurements were carried out at 29 locations (Figure 1) during June and July of 2017: 28 gas wells and 1 oil well (RWK-14).

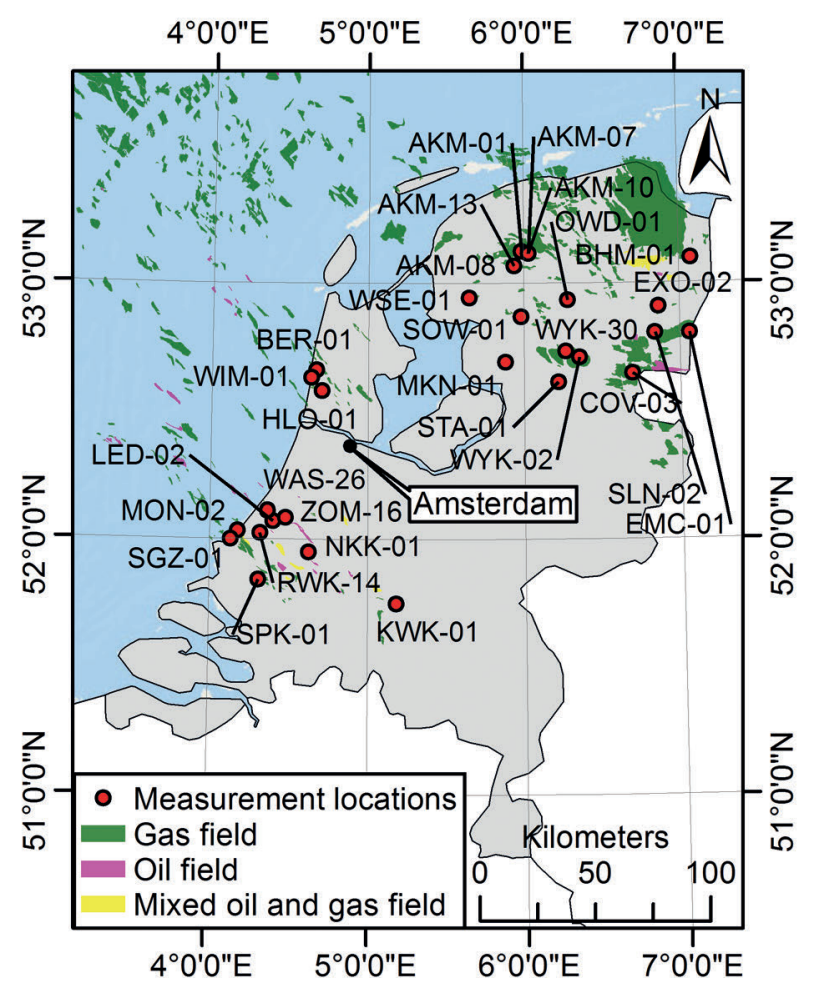

Figure 1 | Locations of the 29 investigated abandoned wells together with the oil and gas fields in the Netherlands (NLOG, 2018). 


\subsection{3 | Surficial scanning}

In the Netherlands, the locations of cut and buried hydrocarbon wells are not visually marked at the ground surface. Hence, they had to be located using GPS based on available coordinates. To decrease the chance of missing methane emissions from a leaking well, methane concentrations at the soil-atmosphere interface were first scanned in a circular area above the abandoned wells. A minimum radius of $15 \mathrm{~m}$ was chosen, which was estimated to be much larger than the uncertainty of the GPS and the given coordinates of the well. Scanning was performed using a Gazomat TDL-500 Inspectra Laser, which measures $\mathrm{CH}_{4}$ concentrations real-time with a resolution of $0.1 \mathrm{ppmv}$ and was checked for accuracy every day using a calibration gas cylinder (50 ppmv). To scan each site thoroughly and in a repeatable manner, the operator of the device was connected with a rope to a cylinder (1 m circumference) placed at the coordinates of the well and had to walk in circles around this cylinder while keeping the rope tight. The resulting spiraling pattern (known as the 'involute of a circle', Figure 2) places the operator closer to the well every lap with a distance equal to the circumference of the cylinder.

A rod with a suction cup was attached to the inlet of the device (Figure 2) that was held just above the soil surface during the scanning and moved from side to side while walking slowly. Additionally, the suction cup was placed directly on the soil at regular intervals and left for 5 - 10 seconds, after which methane concentrations and GPS coordinates were recorded. The locations of any deviating values were marked for subsequent analysis with static chamber flux measurements. The distance along the spiral in between measurements was decreased towards the well, such that the density of measurements was highest near the well location. Scanning in this manner yielded an overall average of around 160 data points per well. Maps of the recorded values for each well location are shown in Figure S.1.

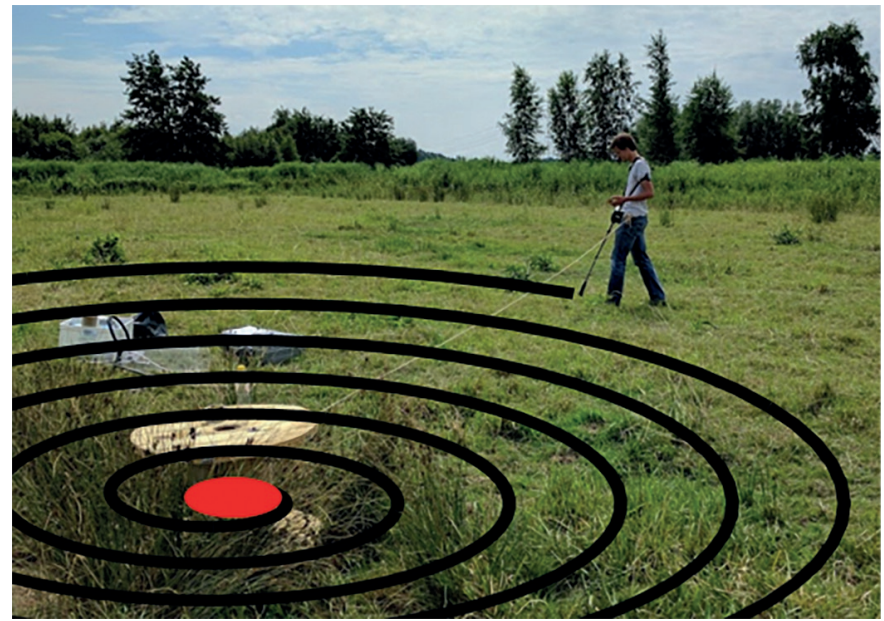

Figure 2 | Photo of the surficial scanning in action. Operator is attached to a wooden cylinder placed on the estimated location of the buried well, as marked with a red dot. The black line schematically shows the remaining path to be walked. 


\subsection{4 | Static chamber measurements}

Static chamber measurements were carried out directly above the buried remains of the well and, for 22 of the 29 well sites, a control location. For consistency, controls were taken at the starting point of the surficial scanning, i.e., a minimum of 15 meters away from the well. This distance was expected to be larger than the uncertainty range associated with locating the well. However, the soil at this location would still be similarly affected by the abandonment procedure of the well(pad), local land use and soil conditions. Measurements were additionally conducted at locations that had elevated methane concentrations during the scanning.

A plexiglas cylindrical chamber (Figure 3) with a height of $56 \mathrm{~cm}$ and a radius of $11.5 \mathrm{~cm}$ was used (volume of $23.25 \mathrm{~L}$ ). To limit gas exchange with the atmosphere, the cylinder was placed on a plastic ring that was pushed $10 \mathrm{~cm}$ into the ground. Methane concentrations in the cylinder were recorded at regular intervals using the Gazomat TDL-500, also used for the surficial scanning. Both the inlet and outlet of this device were connected to the chamber with flexible tubing, such that measured gas was returned to the chamber (Figure 3). The pumping rate of the device was $70 \mathrm{~L} \mathrm{hr}^{-1}$, which ensured mixing inside the cylinder. After completion of the measurements at the soil surface, $1 \mathrm{~m}$ deep open holes were drilled using a hand auger ( $5 \mathrm{~cm}$ diameter). Measurements were then directly repeated above the newly drilled holes (with the ring still in place).

The mass flow rate into the chamber was calculated using linear regression on the concentration versus time data (Eq. 1).

$$
F=d C / d t \cdot V
$$

Where $\mathrm{F}$ is the $\mathrm{CH}_{4}$ flow rate $\left(\mathrm{mg} \mathrm{hr}^{-1}\right)$, $\mathrm{dC} / \mathrm{dt}$ is the rate of change in $\mathrm{CH}_{4}$ concentration in the chamber [mg $\left.\mathrm{cm}^{-3} \mathrm{hr}^{-1}\right]$ and $\mathrm{V}$ the chamber volume $\left[\mathrm{cm}^{3}\right]$. Similar to previous studies (Kang et al., 2016, 2014), only linear fits with an $\mathrm{R}^{2}$ value greater than 0.8 were considered. $\mathrm{R}^{2}$ values below 0.8 only occurred when the concentration in the chamber remained close to the atmospheric methane concentration. Hence, the methane flow at these locations was assumed to be zero. Measurements were discontinued if no trend or change in concentrations inside the chamber was observed after 5 minutes. While the measurement resolution was 0.1 ppmv, experience learned that measured concentrations sometimes drifted slightly, going up and down within a bandwidth of around 0.5 ppmv. Assuming a temperature of $18^{\circ} \mathrm{C}$ and a pressure of 1 atmosphere, the minimum mass flow that would result in a positive determination within 5 minutes $\left(\Delta \mathrm{CH}_{4} \geq 0.5 \mathrm{ppmv}\right)$ was $0.09 \mathrm{mg} \mathrm{hr}^{-1}$. In some cases the measurement period was extended to lower this detection limit slightly.

\subsubsection{Analysis of gas samples for stable methane isotopes}

Gas samples for isotopic analyses were collected upon completion of the static chamber measurements by placing $1 \mathrm{~L}$ tedlar bags in a sealed box attached directly to the static chamber. Vacuum was created in this box using a foot pump, causing the sample bags to fill with gas from the chamber. As measured fluxes were generally higher at $1 \mathrm{~m}$ depth, it 
was decided to collect samples after these measurements rather than those at the surface. Samples were collected at additional locations if methane leakage from the abandoned well was suspected. Analyses of the samples were carried out at the Institute for Atmospheric and Marine Research (IMAU) of the Utrecht University. Methane was extracted as described in Röckmann et al. (2016): methane carbon $\left({ }^{13} \mathrm{C}^{-} \mathrm{CH}_{4}\right)$ and hydrogen $\left(\delta^{2} \mathrm{H}-\mathrm{CH}_{4}\right)$ stable isotope ratios were determined in separate measurements by Isotope Ratio Mass Spectrometry (IRMS) on a Thermo Finnigan Delta plus XP. The sample mixing ratio and isotopic composition were determined by comparing the measurements to that of a known reference air that was extracted in the same way.

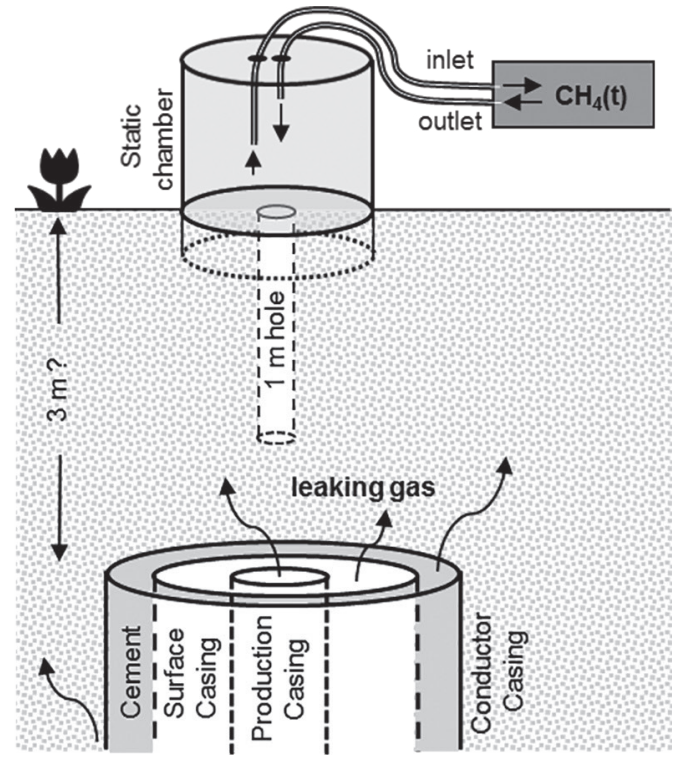

Figure 3 | Schematic representation of the static chamber measurements carried out above plugged, cut and buried wells. Chamber dimensions were $56 \mathrm{~cm}$ height, $11.5 \mathrm{~cm}$ radius, $23.25 \mathrm{~L}$ volume. Static chamber measurements were first carried before drilling the $1 \mathrm{~m}$ hole on which additional static chamber measurements were conducted. Figure not to scale.

\subsubsection{Detailed characterization of methane leakage at the MON-02 site}

Thermogenic methane was observed at well MON-02 following the previously described procedures. This site was therefore characterized in more detail. Well MON-02 produced from the 'Monster' gas field (Figure 1), a small gas accumulation in the West Netherlands Basin, and was abandoned in the 1990s. The reservoir consists of a series of Triassic layers known together as the Main Bundsandstein Subgroup, and is situated at a depth around 2800 to $3000 \mathrm{~m}$. Starting at the coordinates of the abandoned wellbore, static chamber measurements were carried out in each cardinal direction with a $2 \mathrm{~m}$ spacing. Once a negligible flux was identified at $1 \mathrm{~m}$ depth, measurements were continued in the next direction. This procedure led to 14 measurement locations that form a grid like pattern, with each measurement representing an area of 2 by $2 \mathrm{~m}$. In addition to the procedure described in section 2.4, static chamber measurements were also conducted at $2 \mathrm{~m}$ depth, slightly above the groundwater table at 
this location ( $2.2 \mathrm{mbgl}$ ). This was done by extending the already drilled holes to $2 \mathrm{~m}$ once the $1 \mathrm{~m}$ deep measurements were completed. Furthermore, PVC tubes with the same length and diameter $(5 \mathrm{~cm})$ as the drilled holes were placed inside the holes and connected directly to the chamber so that flow into the chamber could only occur from the bottom of the tube. A sandy soil profile was encountered throughout the site. Samples for isotopic analysis were collected at the end of seven measurements of a single transect: three at $1 \mathrm{~m}$ depth and four at $2 \mathrm{~m}$ depth.

In total, 28 static flux measurements were carried out (Table S.2). Regression was performed over a linear part of the data $\left(R^{2} \geq 0.8\right)$ of at minimum 50 seconds in order to calculate the flow rates. To estimate the total leakage flux from the well the methane flow rates were converted to a measured mass flux (Eq. 2):

$$
J_{m}=F / A_{t}
$$

Where $J_{m}$ is the measured $\mathrm{CH}_{4}$ flux $\left[\mathrm{mg} \mathrm{cm}^{-2} \mathrm{hr}^{-1}\right]$ and $\mathrm{A}_{t}$ is the surficial area of the opening of the tube $\left[\mathrm{cm}^{2}\right]$. Due to the lack of a porous medium inside the tube, the diffusive flux towards the chamber was enhanced compared to the initial, undisturbed soil condition. To account for this, measurements were scaled by the ratio of the diffusion coefficient of methane in sandy soil to that in air, yielding an approximation of the undisturbed flux:

$$
J_{u}=\left(D^{e} / D^{a}\right) J_{m}
$$

where $J_{u}$ is the estimated undisturbed methane flux $\left[\mathrm{mg} \mathrm{cm}^{-2} \mathrm{hr}^{-1}\right]$ and $D^{e}$ and $D^{\text {a }}$ the effective diffusion coefficient in sandy soil and the diffusion coefficient in air, respectively $\left[\mathrm{cm}^{2} \mathrm{hr}^{-1}\right]$. A $\mathrm{D}^{\mathrm{a}}$ of $726 \mathrm{~cm}^{2} \mathrm{hr}^{-1}$ was assumed according to the method of Fuller et al. (1966) for $\mathrm{CH}_{4}$ at $18^{\circ} \mathrm{C}$ and 1015 mbar. The effective diffusion coefficient in sandy soil was calculated as follows (e.g. Scanlon et al., 2002):

$$
D^{e f f}=\phi \tau S^{g} D^{a}
$$

where $\phi$ is the porosity [-], $\mathrm{S}^{\mathrm{g}}$ is the saturation of the gas phase [-] and $\tau$ the tortuosity factor (determined according to Penman, 1940a, 1940b). A porosity of 0.3 and soil gas saturation of 0.9 were assumed. Finally, the total leakage flux from the well was calculated by means of a nearest neighbor interpolation, at 1 and $2 \mathrm{~m}$ depth separately: first, the estimated undisturbed flux for each measurement location was extrapolated to the $2 \times 2 \mathrm{~m}$ square area surrounding it and then all data points were summed.

\section{3 | RESULTS}

\subsection{1 | Surficial scanning}

Surficial scanning of methane concentrations at the soil-atmosphere interface was carried out fully at 19 and partly at 5 of the 29 selected well sites (Figure S.1). At 10 locations obstructions such as canals or dense undergrowth either partially or fully limited the 
required mobility (see for example Figure 4B). During the course of most measurements, observed concentrations tended to drift around the atmospheric methane concentration ( 1.8 ppmv) between roughly 1.1 and 2.5 ppmv. Thus, observed patterns of both increasing and decreasing concentrations could not be related to locally enhanced methane emissions or uptake by the soil as long as the concentration changes remained within this bandwidth (e.g. Figure 4A and Figure 4B). Isolated locations with concentrations greater than 2.5 ppmv were observed at 6 well sites (Figure S.1). In most cases, these observations were temporary concentration spikes and could not be reproduced on subsequent measurements. However, these locations were marked for later investigation using the static chamber setup. Only while scanning well site NKK-01 elevated methane concentrations up to several hundred ppmv were observed that also sustained over a longer time period (Figure 4C).
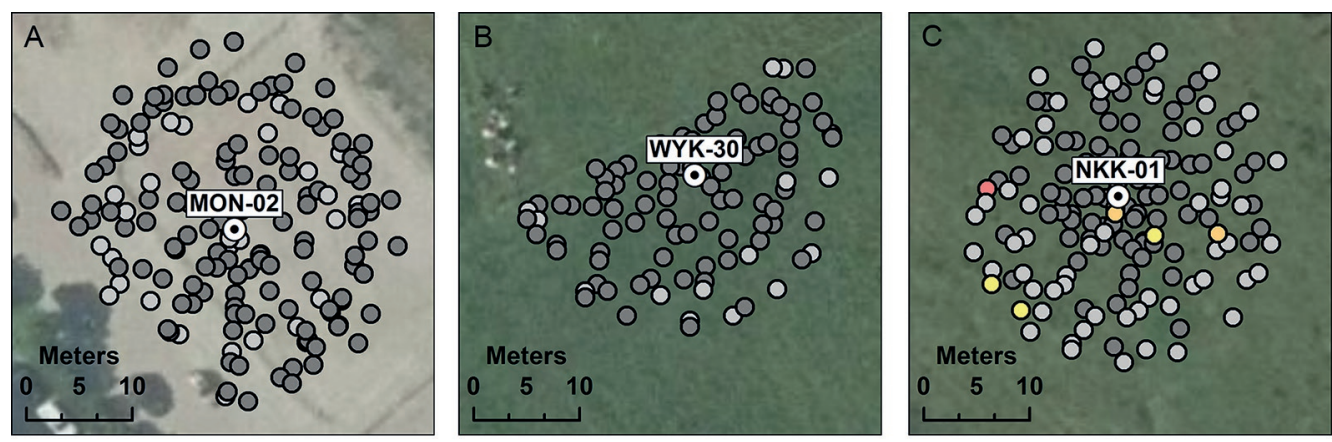

$\mathrm{CH} 4$ concentration [ppmv]

$0<1.8$ O $1.8-2.5$ O $2.5-10$ O $10-100 \quad 0>100$

Figure 4 | Three examples of the results obtained during surficial scanning of methane concentrations: (A) MON-02, (B) WYK-30, where only half the scanning spiral could be executed and (C) NKK-01, where several concentration outliers were identified that were marked for static chamber flux measurements.

\subsubsection{Static chamber measurements at surface and $1 \mathrm{~m}$ depth}

The static chamber measurements carried out at the soil surface directly above the 29 buried wells revealed only a single location with a positive methane flow rate: AKM-07 (Figure 5, Table S.1). In contrast, flow rates were negative at the surface above four wells, and no measurable methane flow was recorded above the remaining wells. The surficial static chamber measurements also revealed two positive and one negative flow rate at the control locations; flow could not be detected at the remaining control locations. Negative flow rates are interpreted as methane uptake from the soil caused by methane oxidation in the vadose zone. At $1 \mathrm{~m}$ depth, positive methane flow rates were observed more frequently than at the surface while negative flow rates were only observed at two control locations. Overall, 15 of 29 well locations and 10 of 22 control locations had a positive methane flow rate at $1 \mathrm{~m}$ depth (Figure 5). With the exception of well NKK-01, measurements carried out at locations 
that were marked because of concentration outliers observed during the surficial scanning did not yield appreciably higher flow rates. Hence, these measurements were not considered for further interpretation.

Methane flow rates at $1 \mathrm{~m}$ depth were larger above the buried wells than at their respective control for 6 locations. Conversely, control measurements were larger at 8 other locations (Figure 5). The remaining 8 locations where control measurements were conducted had undetectable flow rates both above the buried wells and at the control locations. As can be seen in Figure 5, the variability in flow rate between the well and control locations was such that the difference between them could not be relied upon to attribute measured flow rates above the buried wells to well integrity failure. A clear positive outlier was, however, observed at well MON-02 with a flow rate of $1418 \mathrm{mg} \mathrm{hr}^{-1}$ at $1 \mathrm{~m}$ depth. This is more than two orders of magnitude higher than the next highest flow rate measurement in the entire study. Furthermore, this high flow rate contrasted with the negative flow rate measured at $1 \mathrm{~m}$ depth at the control location, the undetectable flow rates at the surface and the lack of elevated concentrations recorded during the surficial scanning (Figure 4A).
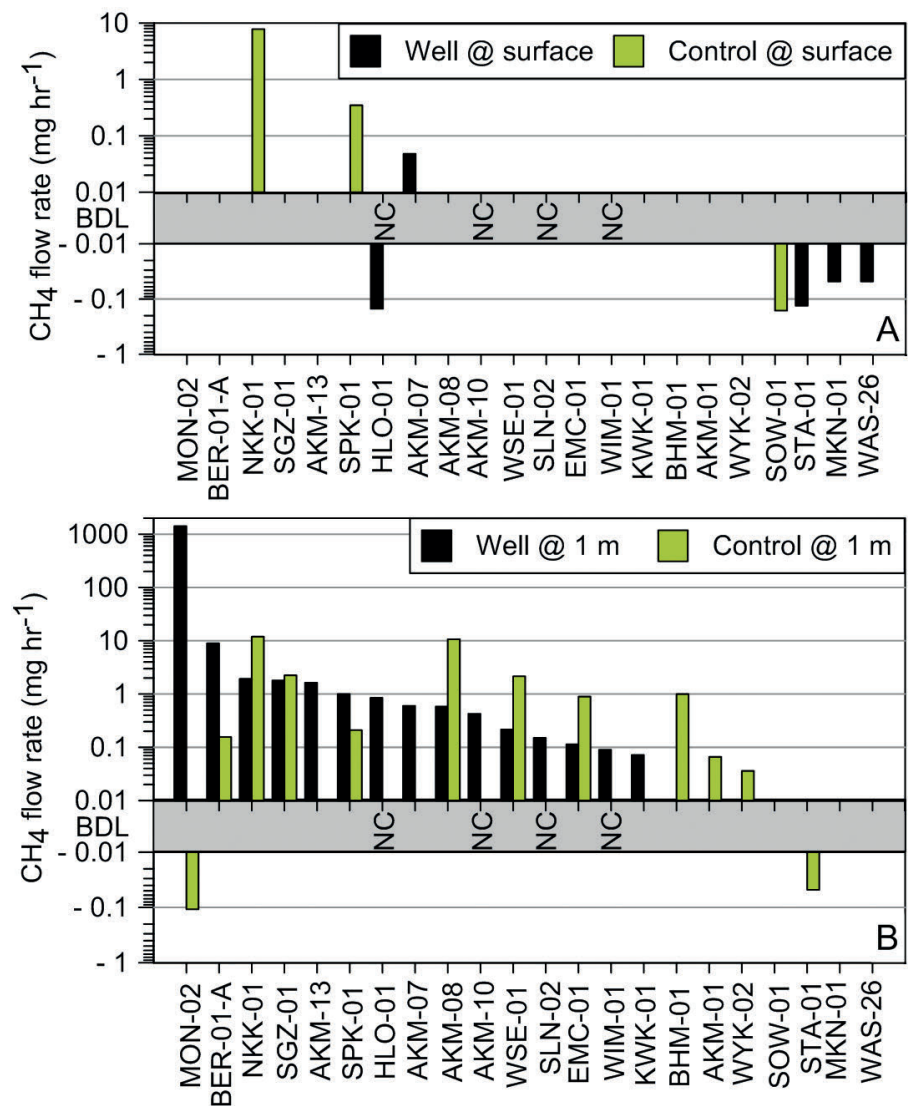

Figure 5 | Methane flow rates at the surface $(A)$ and at $1 \mathrm{~m}$ depth (B) as determined by static chamber flux measurements. Locations are shown that have at minimum one non-zero measurement (22 out of 29 locations). Grey area is below the detection limit ('BDL'), locations where no control measurements were carried out are labelled with 'NC'. 


\subsubsection{Analysis methane stable isotopes}

Only the sample collected after the flux measurement at $1 \mathrm{~m}$ depth above well MON-02, where the highest single flux measurement was observed, had a clear thermogenic origin $\left({ }^{13} \mathrm{C}-\mathrm{CH}_{4}=-26.6 \%\right.$ and $\delta \mathrm{D}-\mathrm{CH}_{4}=-149.7 \%$, Figure 6). This is convincing evidence that leakage of natural gas caused by well integrity failure was occurring. Samples from other locations with high flow rates had isotopic compositions indicative of a biogenic origin, with a $\delta^{13} \mathrm{C}_{-} \mathrm{CH}_{4}<50 \%$ and a $\delta \mathrm{D}-\mathrm{CH}_{4}<-225 \%$, regardless of whether the fluxes above the well or at the control location had given higher fluxes. A biogenic gas source was also confirmed at well NKK-01, the only location where high methane concentrations where recorded during the surficial scanning that also resulted in positive flow rate measurements at the surface. The bacterial methane is likely related to the presence of organic-rich formations, abundant in the shallow subsurface of the Netherlands. Many oil and gas fields in the Netherlands are found in the coastal provinces, where Holocene peat and clay deposits are also present (Wong et al., 2007). Methane emissions from these deposits are well known (Van Den Pol-Van Dasselaar et al., 1999). Samples from locations with intermediate flow rates showed isotopic compositions that can be explained by mixing of biogenic and atmospheric methane, while sites with zero or low flow rates showed an atmospheric origin with $\delta{ }^{13} \mathrm{C}-\mathrm{CH}_{4}$ and $\delta \mathrm{D}-\mathrm{CH}_{4}$ values of around $-47 \%$ and $-93 \%$, respectively (Figure 6).

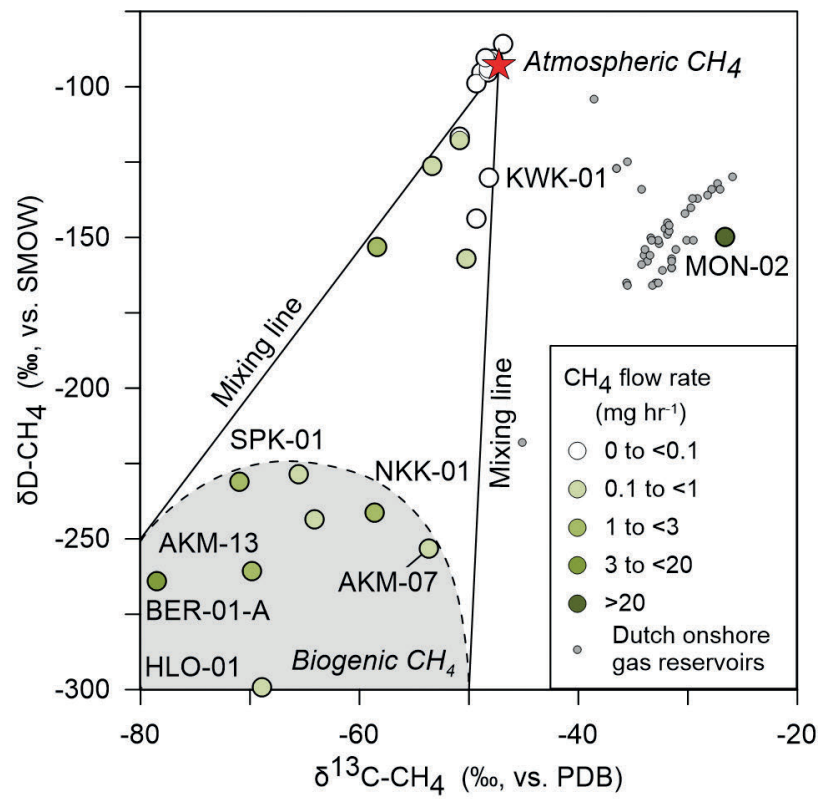

Figure 6 | Carbon and hydrogen isotopic composition of methane in samples collected after completion of static chamber measurements at $1 \mathrm{~m}$ depth. Grey dots show isotopic composition of samples taken from onshore Dutch gas reservoirs (NLOG, 2018). Isotopic composition of northern-hemisphere atmospheric methane based on Rice et al. (2016). 


\subsubsection{Detailed characterization of methane leakage at the MON-02 site}

The detailed characterization carried out at well MON-02 showed that the estimated undisturbed methane fluxes were significantly higher at $2 \mathrm{~m}$ depth than at $1 \mathrm{~m}$ depth (Figure 7). At the location directly overlying the coordinates of the abandoned wellbore (A1), the estimated undisturbed flux at $1 \mathrm{~m}$ depth was $9.4 \mathrm{~g} \mathrm{~m}^{-2} \mathrm{hr}^{-1}$ compared to $19.6 \mathrm{~g} \mathrm{~m}^{-2} \mathrm{hr}^{-1}$ at $2 \mathrm{~m}$ depth. While the maximum flux at $1 \mathrm{~m}$ depth was located at the coordinates of the well, the maximum flux at $2 \mathrm{~m}$ depth was located almost $3 \mathrm{~m}$ to the south (B2) and was 4.5 times larger than the maximum flux at $1 \mathrm{~m}$ depth: $40.4 \mathrm{~g} \mathrm{CH}_{4} \mathrm{~m}^{-2} \mathrm{hr}^{-1}$. Considerable lateral spreading is observed with fluxes greater than $2 \mathrm{~g} \mathrm{~m}^{-2} \mathrm{hr}^{-1}$ measured up to $4.5 \mathrm{~m}$ distance from the well coordinates at $1 \mathrm{~m}$ depth and up to $6 \mathrm{~m}$ at $2 \mathrm{~m}$ depth. If subsurface methane concentrations had solely been the result of diffusion from a buried point source through a homogeneous, sandy porous medium (as encountered at the site), spreading would have occurred in semispherical manner in all directions equally. However, this is not the case, as illustrated by the fact that the fluxes just $2 \mathrm{~m}$ northeast of the coordinates of the well (01) were zero at both 1 and $2 \mathrm{~m}$ depth. Nearest neighbor interpolation of the data yielded a total leakage flux estimate of $111 \mathrm{~g} \mathrm{hr}^{-1}$ at $1 \mathrm{~m}$ depth and $443 \mathrm{~g} \mathrm{hr}^{-1}$ at $2 \mathrm{~m}$ depth. At atmospheric pressure and a temperature of $18{ }^{\circ} \mathrm{C}$, this is equal to a volumetric flux of 4.0 and $15.8 \mathrm{~m}^{3}$ day $^{-1}$, respectively. Furthermore, it suggests that a reduction in flux of 74\% had occurred from 2 to $1 \mathrm{~m}$ depth. Isotopic compositions of the 7 collected samples at MON-02 varied significantly (Figure 8). The isotopic composition of methane from the Monster gas reservoir is known from a publicly available analysis of a gas sample collected from nearby gas well MON-03 (NLOG, 2018). The sample collected at the location with the lowest flux (A4-2m) lies close to the mixing line of gas from the reservoir and atmospheric methane. The samples that are isotopically most similar to that of the reservoir are three samples collected at $2 \mathrm{~m}$ depth at the locations with the highest flux measurements (A1-2m, $A 2-2 m$ and $A 3-2 m$ ). Relative to these three samples, two of the samples from $1 \mathrm{~m}$ depth (A1-1m and $A 3-1 \mathrm{~m}$ ) are enriched in both their carbon and hydrogen isotopic composition. This is indicative of the occurrence of aerobic microbial methane oxidation as the isotopic fractionation factors observed for aerobic methane oxidation in Dutch and German soils $\left(a^{13} \mathrm{C}=1.008\right.$ and $\mathrm{aD}=1.0039$, Bergamaschi et al., 1998) qualitatively match the shift from the samples collected at $2 \mathrm{~m}$ depth to those at $1 \mathrm{~m}$ depth (Figure 8). Following the methods described in Whiticar (1999), the observed shift can be related to a residual methane fraction of $75 \%$. In other words, methane oxidation can account for up to $25 \%$ of the reduction in methane flux as observed from 2 to $1 \mathrm{~m}$ depth.

The isotopic composition of sample A2-1m, which is isotopically depleted compared to the reservoir gas, represents an outlier that cannot be explained by leakage of gas from the Monster gas reservoir. Possibly the leaking gas here does not originate from the reservoir, but rather from an intermediate formation. The most likely candidate is the Holland Greensand Member, a known gas-bearing formation in the Netherlands located here at a depth of 1420 to $1481 \mathrm{~m}$. The isotopic composition of this formation is known from two samples taken from a nearby small gas field (Figure 8) and matches that of the sample taken at A2-1m relatively well. 

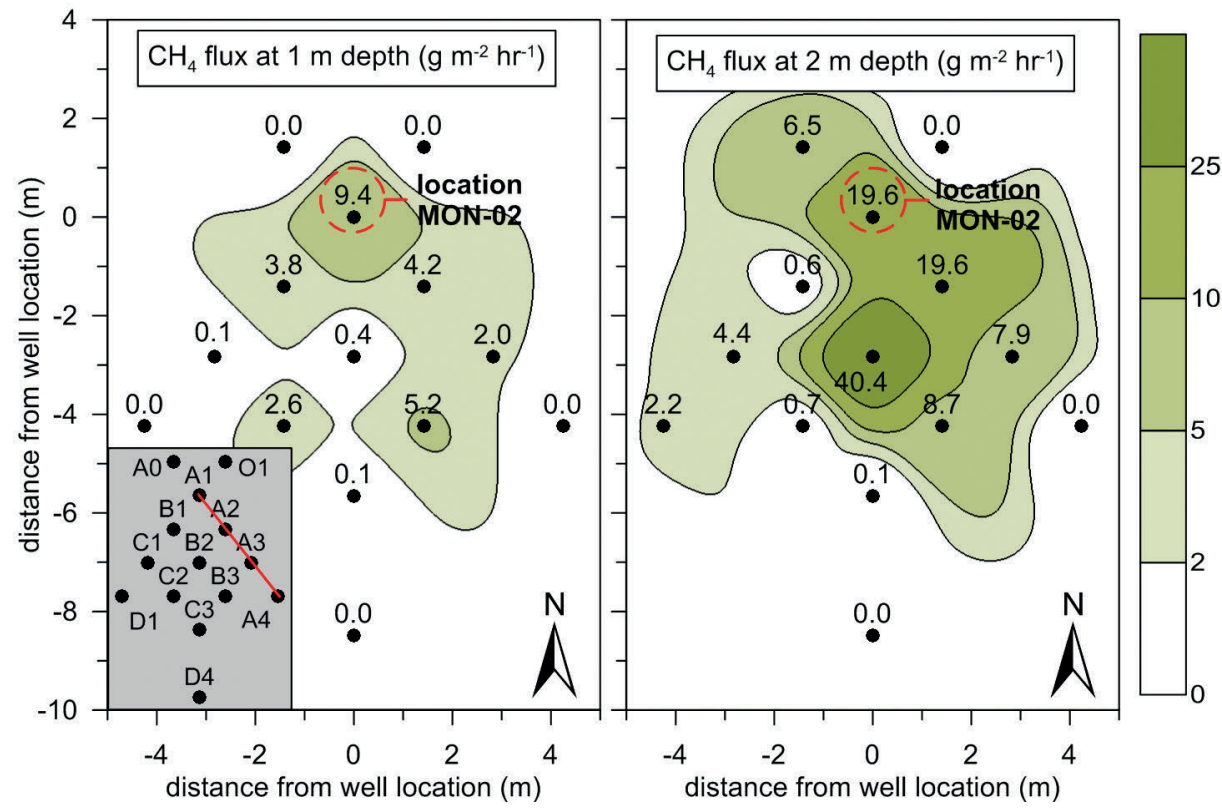

Figure 7 | Results of the detailed investigation at MON-02: values signify the estimated undisturbed fluxes at $1 \mathrm{~m}$ depth (left) and $2 \mathrm{~m}$ depth (right), contours depict the underground spreading of leaked methane but are speculative. Grey inlay shows the label for each position, the red line indicates the locations at which samples were collected for isotopic analysis.

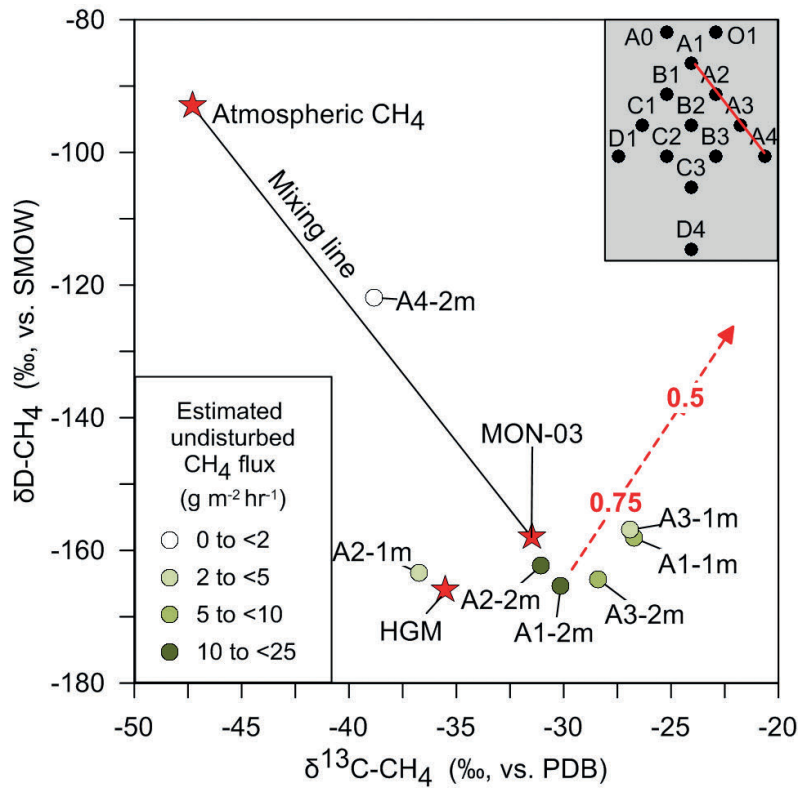

Figure 8 | Isotopic composition and estimated undisturbed flux of seven samples collected as part of the detailed investigation at MON-02 (sampling positions indicated by red line in figure inlay). Two thermogenic end members are shown: Monster reservoir gas (MON-03) and gas from the intermediate Holland Greensand Member (HGM; NLOG, 2018). Red dashed line shows the estimated effect of aerobic methane oxidation, red labels the estimated residual methane fraction. Calculation based on isotopic fractionation factors found in soils above Dutch landfills $(\Delta \mathrm{D} / \Delta \mathrm{C}=4.8$, Bergamaschi et al., 1998). 


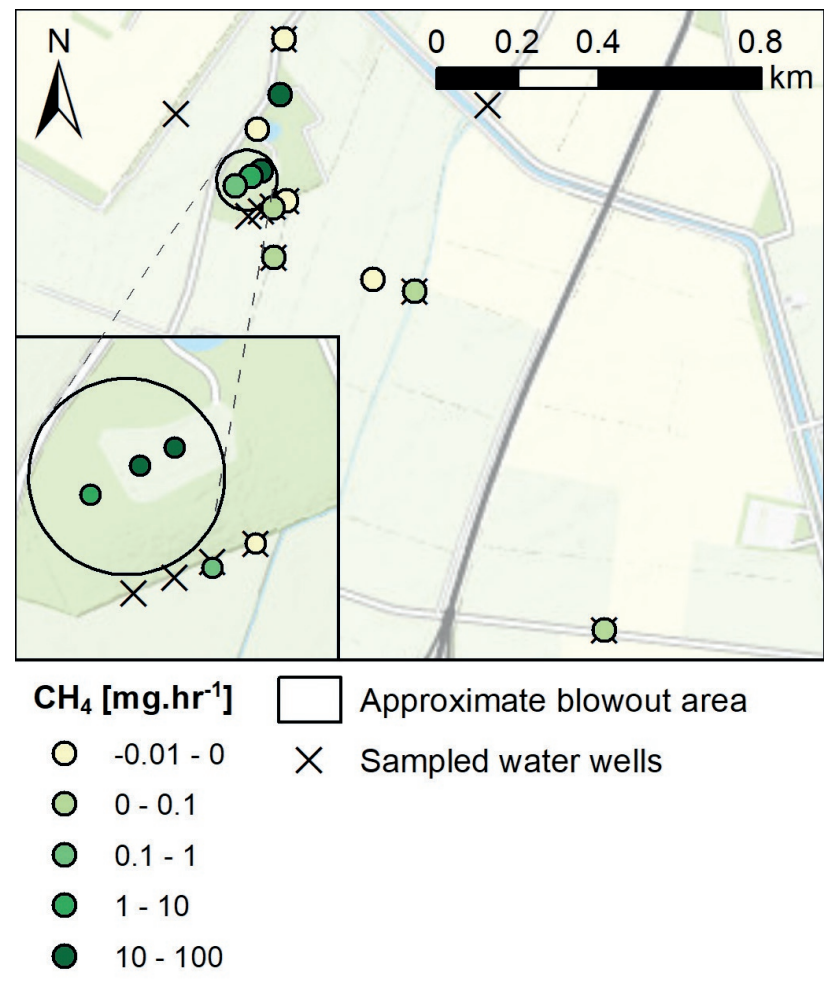

Figure 9 | Methane flow rates at $1 \mathrm{~m}$ depth at the site of the blowout near Sleen. Results of water well sampling are described in detail in chapter 4.

\subsubsection{Additional measurements above Sleen blowout site (SLN-02)}

Besides the static chamber measurements directly above the well location, a number of additional static chamber measurements were carried out in the area around well SLN-02 (Figure 9). At this location, a catastrophic blowout occurred during drilling in in 1965. As described in detail in chapter 4 of this thesis, groundwater at this location still contains thermogenic methane in concentrations close to solubility, and it was concluded that leakage from the reservoir induced by this blowout is likely still ongoing. The static chamber measurements carried out above the spud point of this well were therefore expected to have at least some methane flux, and of thermogenic origin. However, the measured methane flow rates were low (Figure 5) and no thermogenic signal was detected (Figure 6). At some of the additionally measured locations, relatively high methane flow rates up to $23 \mathrm{mg}^{-\mathrm{hr}^{-1}}$ were observed, and high flow rates overlapped with the approximate area that was most affected by the blowout (Figure 9). Nevertheless, samples collected from the 3 locations with the highest flow rates were all clearly biogenic in origin, with $\delta^{13} \mathrm{C}$ values ranging from $-74 \%$ to $-83 \%$, and $\delta D$ values from $-248 \%$ o to $-298 \%$. This outcome shows that besides oxidation, mixing of thermogenic methane with biogenic methane generated in the vadose zone can further mask gas migration. It also suggests that the gas leaking from the reservoir is either completely retained in the subsurface, or emits to the atmosphere at very specific locations that were missed by the static chamber measurements. 


\section{4 | DISCUSSION}

\subsubsection{Detecting gas leakage from cut and buried abandoned wells}

As shown by the results of our study, the occurrence of gas leakage at cut and buried abandoned wells is more easily missed when relying on surface measurements only, as compared with abandoned wells that still have existing wellhead infrastructure protruding to the surface. Besides additional uncertainties on the exact location of the buried well, particularly in the absence of surface markers (as is the case in the Netherlands), leaking methane may become dispersed and oxidized as it migrates from the leakage point towards the surface, not necessarily at the well coordinates due to preferential flow paths. When a leak originates below the groundwater table, upwardly migrating methane can be additionally attenuated by dissolution into groundwater (Cahill et al., 2017). Obviously, when gas leakages result from well integrity failure at greater depth and the gas migrates along the outside of the casing these processes would equally affect methane transport to surface (Dusseault and Jackson, 2014), regardless of whether a well is abandoned, cut and buried, or still protruding to the surface. A combination of these processes caused leakage from a gas well in Colorado, USA, to be undetectable by surficial flux measurements and soil gas probes installed to $60 \mathrm{~cm}$ depth, while methane concentrations in the underlying groundwater were above air-saturation levels (McMahon et al., 2018). Subsurface (vadose zone) measurements using dedicated soil gas wells have previously been employed in soils surrounding oil and gas wells that were not cut and buried by (Lyman et al., 2017). However, while this allows for continued and precise monitoring of soil gas concentrations, our method is less costly and time consuming and therefore enables relatively quick screening at multiple locations.

Methane leakage from a cut and buried wellbore may also be masked by mixing with naturally occurring biogenic methane. Such emissions can be highly spatially variable as a result of soil heterogeneities and preferential pathways (Hendriks et al., 2010). This is illustrated in our study by the detection of hotspots of elevated methane concentrations during the surficial scanning at several locations above one well (NKK-02; Figure 4C), but where isotopic analysis revealed a shallow biogenic origin. Furthermore, local variabilities in biogenic methane fluxes also explain the lack of correlation between the magnitude of the fluxes measured at surface and $1 \mathrm{~m}$ depth as well as their controls (Figure 5). Given these conditions, isotopic confirmation of methane origin is critically important in preventing false negatives or positives in the detection of subsurface gas leakage from a well. At the one well in this study for which gas leakage was confirmed, both the surficial scanning and the surface static chamber measurements did not yield any noticeable indication of leakage (MON-02; Figure 4A, Figure 5). This emphasizes the importance of subsurface measurements of methane flow rates or concentrations, above the level from where leaks could be occurring, as dispersion and oxidation will have had less impact on the methane flux than at the surface. Also, for conditions of high background biogenic methane production, the dilution and mixing of the isotopic signature of the leaking gas would be smaller. 
Although oxidation and dispersion decrease the detectability of methane leakage, isotopic analysis can, in addition to determination of origin, aid in determining the relative importance of these two processes in the total attenuation of the subsurface methane flux from a cut and buried well. As shown by the enrichment of the methane isotopic composition (Figure 8) concurrent with the decrease in flux between 2 and $1 \mathrm{~m}$ below ground surface for the gas leakage occurring at well MON-02 (Figure 7), aerobic methane oxidation accounted for roughly $25 \%$ of this decrease. Hence, around $75 \%$ of the decrease in methane flux towards the surface was attributable to dispersion for that well site. Negative fluxes, resulting from the net oxidation of methane were indeed observed at several of the investigated locations, including at the control location of well MON-02 (Figure 5). Furthermore, the widespread oxidation of subsurface methane fluxes (whether biogenic or thermogenic) is also suggested by the consistently larger fluxes measured at $1 \mathrm{~m}$ depth than those measured at the surface for the other locations investigated (Figure 5). The extent to which dispersion and oxidation affect the methane flux from subsurface well leakage will however strongly vary between different well locations, depending on the depth of the leakage point, as well as a range of local physical (e.g. water content) and biochemical (e.g. redox conditions, microbial population) conditions and the heterogeneities therein.

\subsection{2 | Estimation of the total methane leakage flux from cut and buried abandoned wells}

At abandoned wells that are not cut and buried, sealing the wellhead off from the atmosphere allows for accurate measurements of the total leakage flux (assuming there is no gas migration outside the casing). At cut and buried wells however, quantification of the total flux is more complex as each measured flux represents an unknown portion of the total flux. Furthermore, while necessary for the detailed characterization of leakage at MON-02, carrying out flux chamber measurements from holes drilled into the soil introduces additional uncertainty by disturbing soil properties and the initial methane concentration distribution in the vadose zone. The three most notable sources of uncertainty include first that we had to compensate for the lack of a porous medium in the tube installed into the drilled holes by scaling the measured flux with the ratio of the effective diffusion coefficient of methane in soil over the diffusion coefficient of methane in pure air. This requires knowledge of the porosity, tortuosity and gas saturation of the porous medium, which we did not determine in the field and hence had to be approximated. Second, the measurements for the detailed investigation did not yield strictly linearly increasing concentration versus time data. Hence, regression analysis had to be carried out on the linear part of the data for that particular flux measurement. The non-linear behavior was likely caused by a combination of factors, including the alteration of soil properties due the drilling, non-vertical and possibly some advective inflow of methane into the tubes, and disruption of the initial methane concentration profile in the soil. Third, interpolation of the measurements at $2 \mathrm{~m}$ depth assumes that methane fluxes are strictly vertical whereas in reality there is an important lateral component (as also shown by the results of our study). Further, the interpolation assumes that the flux is more or less spatially 
distributed and not dominated by fluxes through preferential flow paths. We believe this to be generally valid here given the sandy conditions and the lack of concentration outliers observed during the surficial scanning.

Given the number of sources of uncertainty and the assumptions required under these non-ideal subsurface leakage conditions, our estimation of the flux at $2 \mathrm{~m}$ depth (443 $\mathrm{g} \mathrm{CH}_{4} \mathrm{hr}^{-1}$ or $15.8 \mathrm{~m}^{3} \mathrm{CH}_{4} \mathrm{~d}^{-1}$ ) should be considered an indicative value only. Also, vadose zone processes have been shown to lead to considerable temporal variation of methane fluxes measured by static flux chambers (Forde et al., 2018), and our measurements thus only represent a snapshot of the total leakage flux at one moment in time. Longer term monitoring would be recommended to better contrain the average flux from a leaking well. Future modelling and/or experimental studies may help to determine the validity of the approach taken for the estimation of total leakage flux. In comparison to leakage flux estimates in other studies, our total flux estimate at two meter depth is larger than any of the fluxes identified at plugged wells by both Townsend-Small et al. (2016) and Kang et al. (2016). However, the flux estimate is in the same order of magnitude as the maximum fluxes they observed at unplugged wells. In comparison, surface casing vent flow fluxes appear to be much larger on average: fluxes larger than $10 \mathrm{~m}^{3}$ day $^{-1}$ were observed at 32\% of 11,394 conventional wells with reported leakage issues in Alberta and British Columbia, Canada (Nowamooz et al., 2015). Therefore, our indicative total flux estimate does not seem unrealistic.

\subsubsection{Observed well leakage frequency in context}

This study revealed that methane leakage caused by integrity failure had occurred at 1 out of 28 cut and buried abandoned gas wells (3.6\%). While this value is at the low end of the large range reported for well integrity failure in the review by Davies et al. (2014), it is considerably higher than the $0.06-0.15 \%$ found by Sherwood et al. (2016) in Colorado, USA. However, their findings were based on water chemistry analyses, which is a more indirect measurement and may therefore have contributed to a relatively low leakage frequency. The observed well leakage frequency is larger than that found by Townsend-Small et al., 2016 $(0.8 \%)$ for plugged and abandoned oil and gas wells, part of which had also cut and buried, but lower than both the 30\% reported by Boothroyd et al. (2016) for plugged, cut and buried wells in the UK and the $62 \%$ reported by Kang et al., 2016 for plugged wells that had not been cut and buried. These differences are likely caused by a combination of factors such as the local geology, well type, well construction, well abandonment procedures (King and King, 2013) and the type of monitoring method employed. Here, the amount of wells studies likely plays a role, too. More studies are needed in order to obtain proper insight in the statistics of well integrity failure for the Netherlands as well as globally.

\subsection{4 | Environmental impact of abandoned gas wells in the Netherlands}

Given the limited amount of wells studied, extrapolation of the results can only be done tentatively. Using binomial statistics, the lower and upper probability that could have still 
resulted in 1 positive detection within one standard deviation were calculated to convert our findings to a range. This yields a well integrity failure rate for cut and buried gas wells in the Netherlands of between $1.4 \%$ to $9.0 \%$, which is equal to a range of between 3 to 17 leaking wells when extrapolating to all currently abandoned gas wells $(n=191)$ and between 12 to 81 leaking wells when extrapolating to the total amount of onshore gas wells $(n=906)$. Assuming each well leaks with the estimated flux at $2 \mathrm{~m}$ depth at well MON-02, this gives a rough national estimate of between 10 and 66 ton $\mathrm{CH}_{4} \mathrm{yr}^{-1}$ emitted for the abandoned gas wells, or between 48 to 315 ton $\mathrm{CH}_{4} \mathrm{yr}^{-1}$ for all gas wells. This is equal to between $0.14-0.95 \%$ of the total amount of $\mathrm{CH}_{4}$ estimated to have been emitted by the Dutch energy sector in 2015, and $0.005-0.035 \%$ of the total anthropogenic $\mathrm{CH}_{4}$ emissions in the country (Environmental Data Compendium, 2017). In other terms, the maximum estimated value is equal to the methane produced by roughly 500 Dutch milk cows $\left(\sim 133 \mathrm{~kg} \mathrm{CH}_{4} \mathrm{yr}^{-1} \mathrm{cow}^{-1}\right.$; Velthof et al., 2016). Concluding, it is improbable that the methane leaking from these wells contributes significantly to current anthropogenic GHG gas emissions in the Netherlands.

In the case of cut and buried wells, part of the leaking methane is converted to $\mathrm{CO}_{2}$ as a result of aerobic oxidation. Hence, combining methane concentration measurements with $\mathrm{CO}_{2}$ measurements would be required to fully assess GHG emissions. Given that methane has a global warming potential 24 times that of $\mathrm{CO}_{2}$ (Shindell et al., 2013), $\mathrm{CO}_{2}$ emitted in this manner is likely insignificant for our study area. Notably, leakage from cut and buried oil and gas wells does have to be considered in the context of explosion hazards. This is illustrated by the MON-02 case reported in this study, where the intended construction of several new houses was upheld to repair the leaking abandoned well and ensure the safety of the new buildings.

\section{5 | CONCLUSIONS}

Methane leakage from cut and buried abandoned oil and gas wells is an understudied environmental hazard, and the detection and quantification of leakage at such wells is complex. To assess environmental impact and effective monitoring methods, 28 cut and buried gas wells and 1 oil well were investigated in the Netherlands. Leakage was observed at 1 gas well (MON-02), constituting the first observation of well integrity failure at a properly decommissioned gas well in the country. Neither the surficial methane concentration scanning nor the static flux measurements carried out at the surface proved capable of detecting the leaking gas. However, static flux measurements above $1 \mathrm{~m}$ deep holes drilled into the soil were an effective method. In general, measured flow rates were consistently larger at depth than at the surface. Control measurements showed that naturally occurring biogenic methane fluxes were spatially highly variable. Therefore, the origin of measured fluxes could not be determined based on flux magnitude alone, and analyses of methane stable isotopes were required to distinguish between a biogenic or thermogenic origin. 
A detailed characterization at the leaking well, consisting of static chamber measurements in conducted in a $2 \times 2$ grid from holes drilled to 1 and $2 \mathrm{~m}$ depth, showed that measured flow rates diminished rapidly towards the surface. Enrichment of the isotopic composition concurrent with this decrease confirmed that besides dispersion, aerobic methane oxidation accounted for roughly $25 \%$ of this decrease. Converting the flow rate measurements in the vadose zone to a total flux estimate is not trivial, as each measurement represents only a small portion of the total flux and the drilling of the holes required for the measurements disturbs the soil properties. Nevertheless, an indicative value was computed by converting each measurement at $2 \mathrm{~m}$ depth to estimates of the 'undisturbed' flux and then interpolating using nearest neighbour interpolation. This approach yields a value of $443 \mathrm{~g} \mathrm{CH}_{4} \mathrm{hr}^{-1}$ emitted from the well. Extrapolating this number to all - abandoned or not - gas wells $(n=906)$ in the Netherlands and taking an uncertainty range of 1.4 to $9.0 \%$ for the well integrity failure rate yields a first estimate of $48-315$ ton $\mathrm{CH}_{4} \mathrm{yr}^{-1}$. This is negligible compared to the yearly methane emissions from the energy sector $(0.14-0.95 \%)$ and overall anthropogenic methane emissions $(0.005-0.035 \%)$ in the Netherlands.

Taken together, these findings support the need for subsurface measurements when trying to detect and quantify methane leakage from cut and buried gas wells, and have important implications for past and future studies aimed at detecting methane leakage at such wells. However, more research is required to assess whether point measurements of vadose zone methane fluxes can be reliable converted to estimates of the total leakage flux from a cut and buried well. In spite of considerable uncertainty, our results show that leakages from gas wells are unlikely to contribute significantly to GHG emissions in the Netherlands. However, the potential explosion hazard caused by methane leakage from cut and buried abandoned wells needs to be taken into account when planning construction projects.

\section{Acknowledgements}

We thank KWR Watercycle Research Institute for providing guidance on field methods and field materials, Carina van der Veen for carrying out the analyses of our samples at the IMAU lab, and Hans Oonk for making available his portable methane analyzer for our study. This work is part of the research program 'Shale Gas and Water' with project number 859.14.001, which is financed by the Dutch Research Council (NWO). 


\section{REFERENCES}

Bergamaschi, P., Lubina, C., Königstedt, R., Fischer, H., Veltkamp, A.C., Zwaagstra, O., 1998. Stable isotope signatures (d13C, dD) of methane from European landfill sites. J. Geophys. Res. 103, 8251-8265. https://doi.org/https://doi.org/10.1029/98JD00105

Boothroyd, I.M., Almond, S., Qassim, S.M., Worrall, F., Davies, R.J., 2016. Fugitive emissions of methane from abandoned, decommissioned oil and gas wells. Sci. Total Environ. 547, 461-469. https:// doi.org/10.1016/j.scitotenv.2015.12.096

Brufatto, C., Cochran Aberdeen, J., Lee Conn David Power, S., Zaki Abd Alla El-Zeghaty, S., Fraboulet, B., Griffin, T., James Trevor Munk, S., Justus Santa Cruz, F., Joseph Levine, B.R., Montgomery, C., Murphy, D., Pfeiffer Houston, J., Tiraputra Pornpoch, T., Rishmani Abu Dhabi, L., 2003. From Mud to Cement - Building Gas Wells. Oilf. Rev. 62-76.

Cahill, A.G., Steelman, C.M., Forde, O., Kuloyo, O., Emil Ruff, S., Mayer, B., Ulrich Mayer, K., Strous, M., Cathryn Ryan, M., Cherry, J.A., Parker, B.L., 2017. Mobility and persistence of methane in groundwater in a controlled-release field experiment. Nat. Geosci. https://doi.org/10.1038/ ngeo2919

Chilingar, G. V., Endres, B., 2005. Environmental hazards posed by the Los Angeles Basin urban oilfields: An historical perspective of lessons learned. Environ. Geol. https://doi.org/10.1007/s00254004-1159-0

Darrah, T.H., Vengosh, A., Jackson, R.B., Warner, N.R., Poreda, R.J., 2014. Noble gases identify the mechanisms of fugitive gas contamination in drinking-water wells overlying the Marcellus and Barnett Shales. Proc. Natl. Acad. Sci. 111, 14076-14081. https://doi.org/10.1073/pnas. 1322107111

Davies, R.J., Almond, S., Ward, R.S., Jackson, R.B., Adams, C., Worrall, F., Herringshaw, L.G., Gluyas, J.G., Whitehead, M.A., 2014. Oil and gas wells and their integrity: Implications for shale and unconventional resource exploitation. Mar. Pet. Geol. 56, 239-254.

Dusseault, M., Jackson, R., 2014. Seepage pathway assessment for natural gas to shallow groundwater during well stimulation, in production, and after abandonment. Environ. Geosci. 21, 107-126. https://doi.org/10.1306/eg.04231414004

Dusseault, M.B., Gray, M.N., Nawrocki, P. a, 2000. Why Oilwells Leak : Cement Behavior and Long-Term Consequences. SPE Int. Oil Gas Conf. Exhib. SPE 64733 8. https://doi.org/10.2118/64733-MS

Dusseault, M.B., Jackson, R.E., MacDonald, D., 2014. Towards a Road Map for Mitigating the Rates and Occurrences of Long-Term Wellbore Leakage. Geofirma 1-69.

Environmental Data Compendium, 2017. Greenhouse gas emissions the Netherlands, 1990-2016 [WWW Document]. URL http://www.clo.nl/en/indicators/en0165-greenhouse-gas-emissions (accessed 7.7.18).

Erno, B., Schmitz, R., 1996. Measurements of Soil Gas Migration Around Oil And Gas Wells In the Lloydminster Area. J. Can. Pet. Technol. 35, 37-46. https://doi.org/10.2118/96-07-05

Forde, O.N., Mayer, K.U., Cahill, A.G., Mayer, B., Cherry, J.A., Parker, B.L., 2018. Vadose Zone Gas Migration and Surface Effluxes after a Controlled Natural Gas Release into an Unconfined Shallow Aquifer. Vadose Zo. J. 17, 0. https://doi.org/10.2136/vzj2018.02.0033

Forde, O.N., Mayer, K.U., Hunkeler, D., 2019. Identification, spatial extent and distribution of fugitive gas migration on the well pad scale. Sci. Total Environ. 652, 356-366. https://doi.org/10.1016/j. scitotenv.2018.10.217Fuller, E.N., Schettler, P.D., Giddings, J.C., 1966. A new method for prediction of binary gas-phase diffusion coefficients. Ind. Eng. Chem. 58, 18-27. https://doi. org/10.1021/ie50677a007 
Gorody, A.W., 2012. Factors affecting the variability of stray gas concentration and composition in groundwater. Environ. Geosci. 19, 17-31. https://doi.org/10.1306/eg.12081111013

Harrison, S.S., 1983. Evaluating System for Ground-Water Contamination Hazards Due to Gas-Well Drilling on the Glaciated Appalachian Plateau. Groundwater 21, 689-700. https://doi. org/10.1111/j.1745-6584.1983.tb01940.x

Hendriks, D.M.D., van Huissteden, J., Dolman, A.J., 2010. Multi-technique assessment of spatial and temporal variability of methane fluxes in a peat meadow. Agric. For. Meteorol. https://doi. org/10.1016/j.agrformet.2009.06.017

Ingraffea, A.R., Wells, M.T., Santoro, R.L., Shonkoff, S.B.C., 2014. Assessment and risk analysis of casing and cement impairment in oil and gas wells in Pennsylvania, 2000-2012. Proc. Natl. Acad. Sci. 111, 10955-10960. https://doi.org/10.1073/pnas.1323422111

Jackson, R.B., Vengosh, A., Darrah, T.H., Warner, N.R., Down, A., Poreda, R.J., Osborn, S.G., Zhao, K., Karr, J.D., 2013. Increased stray gas abundance in a subset of drinking water wells near Marcellus shale gas extraction. Proc. Natl. Acad. Sci. 110, 11250-11255. https://doi.org/10.1073/ pnas. 1221635110

Kang, M., Christian, S., Celia, M.A., Mauzerall, D.L., Bill, M., Miller, A.R., Chen, Y., Conrad, M.E., Darrah, T.H., Jackson, R.B., 2016. Identification and characterization of high methane-emitting abandoned oil and gas wells. Proc. Natl. Acad. Sci. 113, 201605913. https://doi.org/10.1073/pnas.1605913113

Kang, M., Kanno, C.M., Reid, M.C., Zhang, X., Mauzerall, D.L., Celia, M.A., Chen, Y., Onstott, T.C., 2014. Direct measurements of methane emissions from abandoned oil and gas wells in Pennsylvania. Proc. Natl. Acad. Sci. U. S. A. 111, 18173-7. https://doi.org/10.1073/pnas.1408315111

Kelly, W.R., Matisoff, G., Fisher, J.B., 1985. The effects of a gas well blow out on groundwater chemistry. Environ. Geol. Water Sci. 7, 205-213. https://doi.org/10.1007/BF02509921

King, G.E., King, D.E., 2013. Environmental Risk Arising From Well-Construction Failure - Differences Between Barrier and Well Failure, and Estimates of Failure Frequency Across Common Well Types, Locations, and Well Age. SPE Prod. Oper. 28, 323-344. https://doi.org/10.2118/166142-PA

Lackey, G., Rajaram, H., Sherwood, O.A., Burke, T.L., Ryan, J.N., 2017. Surface Casing Pressure As an Indicator of Well Integrity Loss and Stray Gas Migration in the Wattenberg Field, Colorado. Environ. Sci. Technol. 51, 3567-3574. https://doi.org/10.1021/acs.est.6b06071

Lyman, S.N., Watkins, C., Jones, C.P., Mansfield, M.L., McKinley, M., Kenney, D., Evans, J., 2017. Hydrocarbon and Carbon Dioxide Fluxes from Natural Gas Well Pad Soils and Surrounding Soils in Eastern Utah. Environ. Sci. Technol. 51, 11625-11633. https://doi.org/10.1021/acs.est.7b03408

McMahon, P.B., Thomas, J.C., Crawford, J.T., Dornblaser, M.M., Hunt, A.G., 2018. Methane in groundwater from a leaking gas well, Piceance Basin, Colorado, USA. Sci. Total Environ. 634, 791-801. https:// doi.org/10.1016/j.scitotenv.2018.03.371

Miller, S.M., Wofsy, S.C., Michalak, A.M., Kort, E.A., Andrews, A.E., Biraud, S.C., Dlugokencky, E.J., Eluszkiewicz, J., Fischer, M.L., Janssens-Maenhout, G., Miller, B.R., Miller, J.B., Montzka, S.A., Nehrkorn, T., Sweeney, C., 2013. Anthropogenic emissions of methane in the United States. Proc. Natl. Acad. Sci. 110, 20018-20022. https://doi.org/10.1073/pnas.1314392110

Ministry of Economic Affairs, 2017. Beantwoording Kamervragen over lekkages bij AkzoNobel in Twente (2017Z07676).

Molofsky, L.J., Connor, J. a, Farhat, S.K., Jr, A.S.W., 2011. Methane in Pennsylvania water wells unrelated to Marcellus shale fracturing. Oil Gas J. December 5, 54-67.

NLOG, 2018. Netherlands Oil and Gas Portal Deep Borehole Data [WWW Document]. URL https://www. nlog.nl/en/boreholes (accessed 7.6.18). 
Nowamooz, A., Lemieux, J.M., Molson, J., Therrien, R., 2015. Numerical investigation of methane and formation fluid leakage along the casing of a decommissioned shale gas well. Water Resour. Res. 51, 4592-4622. https://doi.org/10.1002/2014WR016146

Osborn, S.G., Vengosh, A., Warner, N.R., Jackson, R.B., 2011. Methane contamination of drinking water accompanying gas-well drilling and hydraulic fracturing. Proc. Natl. Acad. Sci. 108, E665-E666. https://doi.org/https://doi.org/10.1073/pnas.1100682108

Penman, H.L., 1940a. Gas and vapour movements in the soil: II. The diffusion of carbon dioxide through porous solids. J. Agric. Sci. 30, 570. https://doi.org/10.1017/S0021859600048231

Penman, H.L., 1940b. Gas and vapour movements in the soil: I. The diffusion of vapours through porous solids. J. Agric. Sci. 30, 437. https://doi.org/10.1017/S0021859600048164

Rice, A.L., Butenhoff, C.L., Teama, D.G., Röger, F.H., Khalil, M.A.K., Rasmussen, R.A., 2016. Atmospheric methane isotopic record favors fossil sources flat in 1980s and 1990s with recent increase. Proc. Natl. Acad. Sci. 113, 10791-10796. https://doi.org/10.1073/pnas.1522923113

Röckmann, T., Eyer, S., Van Der Veen, C., Popa, M.E., Tuzson, B., Monteil, G., Houweling, S., Harris, E., Brunner, D., Fischer, H., Zazzeri, G., Lowry, D., Nisbet, E.G., Brand, W.A., Necki, J.M., Emmenegger, L., Mohn, J., 2016. In situ observations of the isotopic composition of methane at the Cabauw tall tower site. Atmos. Chem. Phys. 16, 10469-10487. https://doi.org/10.5194/acp-16-104692016

Scanlon, B.R., Nicot, J.P., Massmann, J.W., 2002. Soil Gas Movement in Unsaturated Systems, in: Warrick, A.W.. (Ed.), Soil Physics Companion. Taylor \& Francis Group, Boca Ration, pp. 297-341. https:// doi.org/doi:10.1201/9781420041651.ch8

Schout, G., Hartog, N., Hassanizadeh, S.M., Griffioen, J., 2017. Impact of an historic underground gas well blowout on the current methane chemistry in a shallow groundwater system. Proc. Natl. Acad. Sci. 115, 201711472. https://doi.org/10.1073/pnas.1711472115

Sherwood, O.A., Rogers, J.D., Lackey, G., Burke, T.L., Osborn, S.G., Ryan, J.N., 2016. Groundwater methane in relation to oil and gas development and shallow coal seams in the Denver-Julesburg Basin of Colorado. Proc. Natl. Acad. Sci. 113, 201523267. https://doi.org/10.1073/pnas.1523267113

Townsend-Small, A., Ferrara, T.W., Lyon, D.R., Fries, A.E., Lamb, B.K., 2016. Emissions of coalbed and natural gas methane from abandoned oil and gas wells in the United States. Geophys. Res. Lett. 43, 2283-2290. https://doi.org/10.1002/2015GL067623

Van Den Pol-Van Dasselaar, A., Van Beusichem, M.L., Oenema, O., 1999. Methane emissions from wet grasslands on peat soil in a nature preserve. Biogeochemistry 44, 205-220. https://doi. org/10.1023/A:1006061814731

Van Der Kuip, M.D.C., Benedictus, T., Wildgust, N., Aiken, T., 2011. High-level integrity assessment of abandoned wells, in: Energy Procedia. pp. 5320-5326. https://doi.org/10.1016/j. egypro.2011.02.513

Van Stempvoort, D., Jaworski, E., 1995. Migration of Methane into Groundwater from Leaking Production Wells near Lloyd minster. Canada: Calgary.

Van Stempvoort, D., Maathuis, H., Jaworski, E., Mayer, B., Rich, K., 2005. Oxidation of fugitive methane in ground water linked to bacterial sulfate reduction. Ground Water 43, 187-199.

van Thienen-Visser, K., Breunese, J.N., 2015. Induced seismicity of the Groningen gas field: History and recent developments. Lead. Edge 34, 664-671. https://doi.org/10.1190/tle34060664.1 
Velthof, G.L., Bruggen, C. Van, Groenestein, C.M., Huijsmans, J.F.M., Luesink, H.H., Sluis, S.M. Van Der, Van der Kolk, J.W.H., Voshaar, S.V.O., Vonk, J., Van Schijndel, M.W., 2016. Referentieraming van emissies naar lucht uit de landbouw tot 2030.; Achtergronddocument bij de Nationale Energieverkenning 2015, met emissies van ammoniak, methaan, lachgas, stikstofoxide en fijnstof uit de landbouw tot 2030. Wageningen.

Vignes, B., 2011. Contribution to well integrity and increased focus on well barriers from a lifecycle aspect. University of Stavanger.

Watson, T.L., Bachu, S., 2009. Evaluation of the Potential for Gas and CO2 Leakage Along Wellbores. SPE Drill. Complet. 24, 115-126. https://doi.org/10.2118/106817-PA

Whiticar, M.J., 1999. Carbon and hydrogen isotope systematics of bacterial formation and oxidation of methane. Chem. Geol. 161, 291-314. https://doi.org/10.1016/s0009-2541(99)00092-3

Wong, T.E., Batjes, D.A.J., Jager, J. de, 2007. Geology of the Netherlands. Royal Netherlands Academy of Arts and Sciences, Amsterdam. 


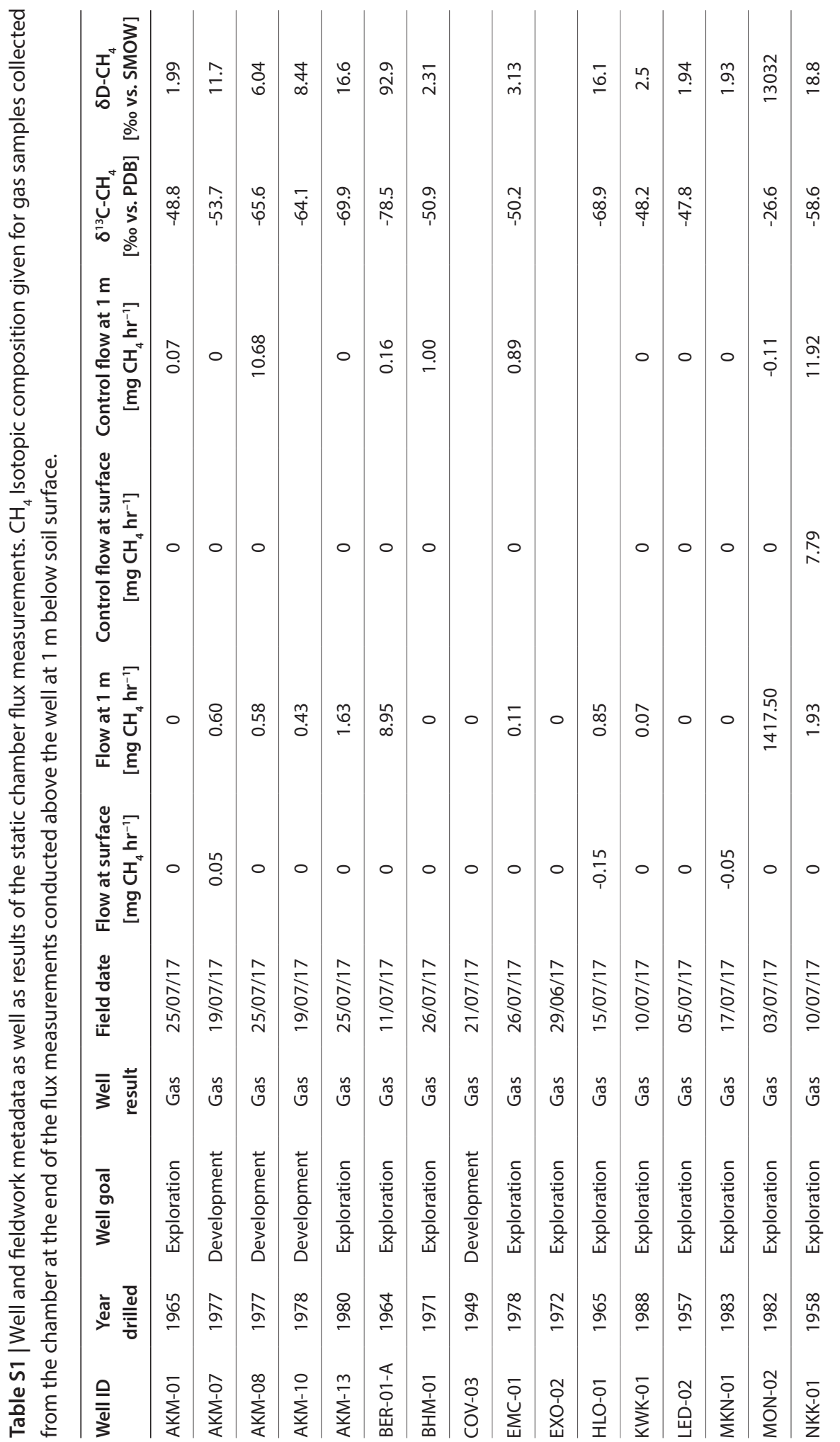




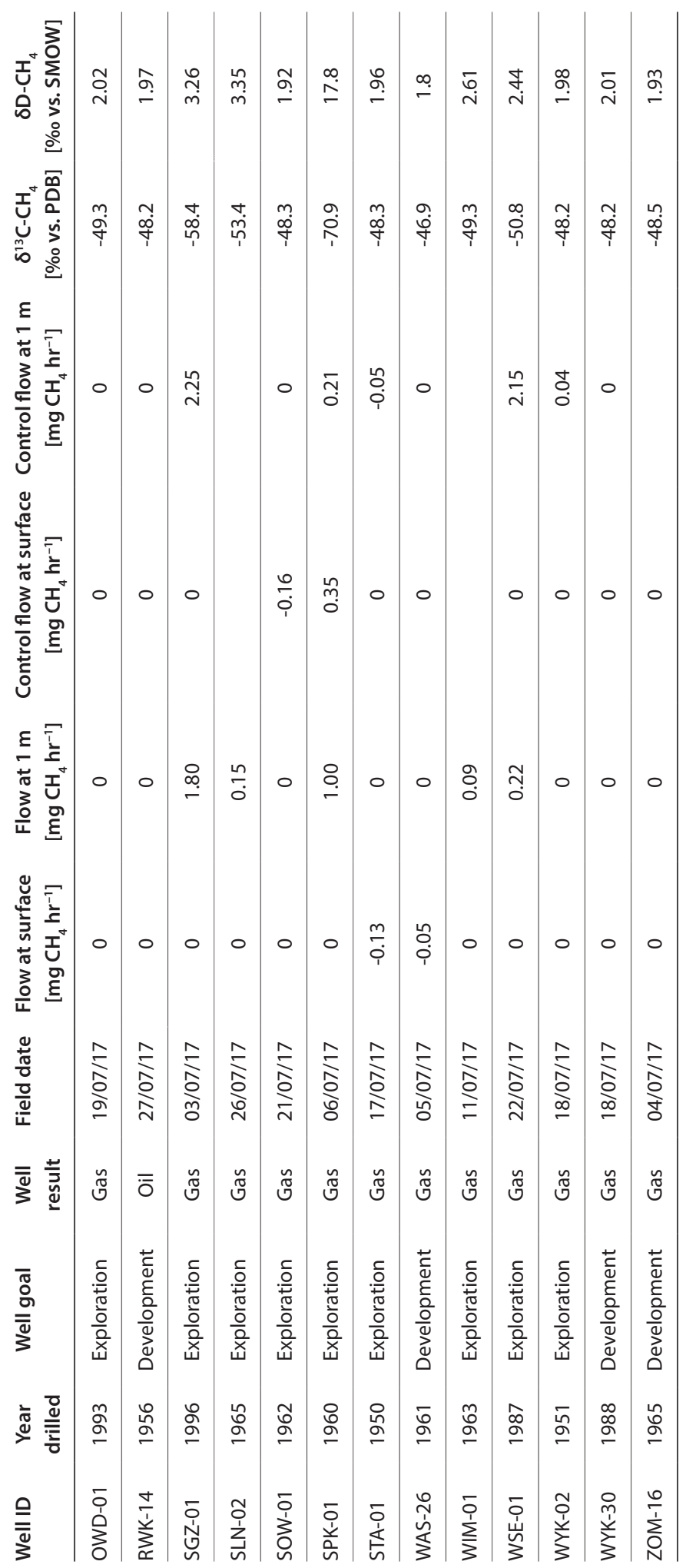


Table S2 | Results of the detailed characterization of the gas leakage at well MON-02.

\begin{tabular}{|c|c|c|c|c|c|c|}
\hline $\begin{array}{l}\text { Measurement } \\
\#\end{array}$ & $\begin{array}{l}\text { Location } \\
\text { ID }\end{array}$ & Depth [m] & $\begin{array}{l}\text { Measured } \\
\text { flow rate } \\
{\left[\mathrm{mg} \mathrm{hr}^{-1}\right]}\end{array}$ & $\begin{array}{c}\text { Estimated } \\
\text { undisturbed } \mathrm{CH}_{4} \\
\text { flux }\left[\mathrm{g} \mathrm{m}^{-2} \mathrm{hr}^{-1}\right]\end{array}$ & $\begin{array}{c}\delta^{13} \mathrm{C}-\mathrm{CH}_{4} \\
\text { [\%o vs. PDB] }\end{array}$ & $\begin{array}{c}\text { SD-CH } \mathrm{CH}_{4} \\
{[\% \circ \text { vs. SMOW] }}\end{array}$ \\
\hline 1 & $\mathrm{~A} 0$ & 1 & 0 & 0.00 & & \\
\hline 2 & A0 & 2 & 238 & 6.48 & & \\
\hline 3 & $\mathrm{~A} 1$ & 1 & 346 & 9.42 & -26.74 & -158.1 \\
\hline 4 & $\mathrm{~A} 1$ & 2 & 721 & 19.64 & -30.14 & -165.4 \\
\hline 5 & $\mathrm{~A} 2$ & 1 & 154 & 4.18 & -36.73 & -163.4 \\
\hline 6 & $\mathrm{~A} 2$ & 2 & 721 & 19.64 & -31.05 & -162.3 \\
\hline 7 & $\mathrm{~A} 3$ & 1 & 75 & 2.04 & -26.91 & -156.9 \\
\hline 8 & A3 & 2 & 289 & 7.86 & -28.38 & -164.4 \\
\hline 9 & A4 & 1 & 0 & 0.00 & & \\
\hline 10 & A4 & 2 & 0 & 0.01 & -38.83 & -121.9 \\
\hline 11 & B1 & 1 & 139 & 3.79 & & \\
\hline 12 & B1 & 2 & 23 & 0.62 & & \\
\hline 13 & B2 & 1 & 14 & 0.39 & & \\
\hline 14 & B2 & 2 & 1482 & 40.36 & & \\
\hline 15 & B3 & 1 & 192 & 5.22 & & \\
\hline 16 & B3 & 2 & 318 & 8.67 & & \\
\hline 17 & $\mathrm{C} 1$ & 1 & 4 & 0.10 & & \\
\hline 18 & $\mathrm{C} 1$ & 2 & 162 & 4.40 & & \\
\hline 19 & $\mathrm{C} 2$ & 1 & 95 & 2.58 & & \\
\hline 20 & $\mathrm{C} 2$ & 2 & 26 & 0.70 & & \\
\hline 21 & $\mathrm{C} 3$ & 1 & 2 & 0.06 & & \\
\hline 22 & C3 & 2 & 5 & 0.13 & & \\
\hline 23 & D1 & 1 & 1 & 0.02 & & \\
\hline 24 & D1 & 2 & 81 & 2.21 & & \\
\hline 25 & D4 & 1 & 1 & 0.02 & & \\
\hline 26 & D4 & 2 & 0 & 0.00 & & \\
\hline 27 & 01 & 1 & 0 & 0.00 & & \\
\hline 28 & 01 & 2 & 0 & 0.00 & & \\
\hline
\end{tabular}



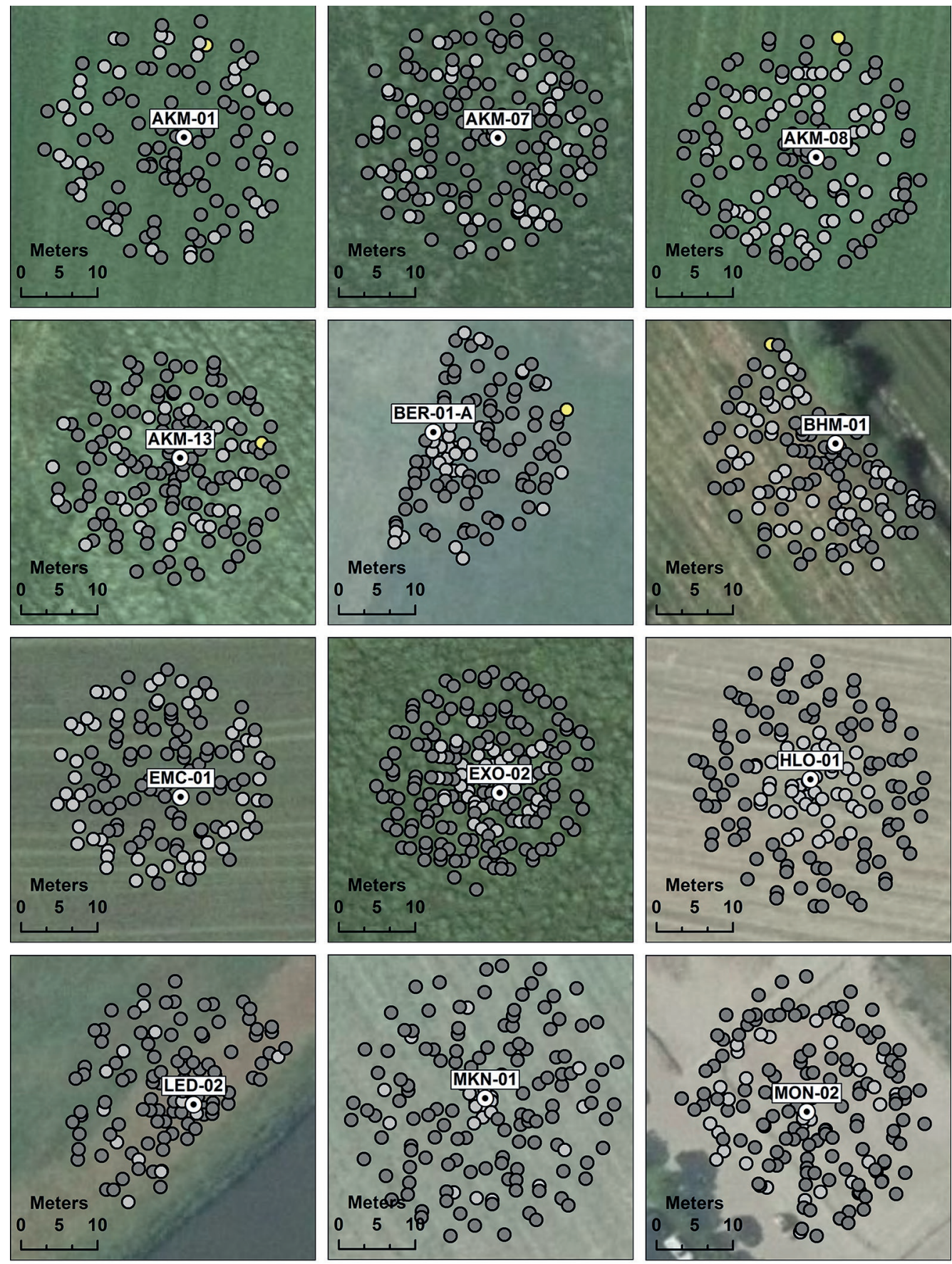

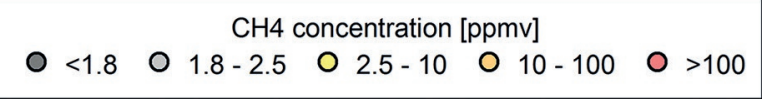

Figure S1 | Results of the surficial scanning measurements. 

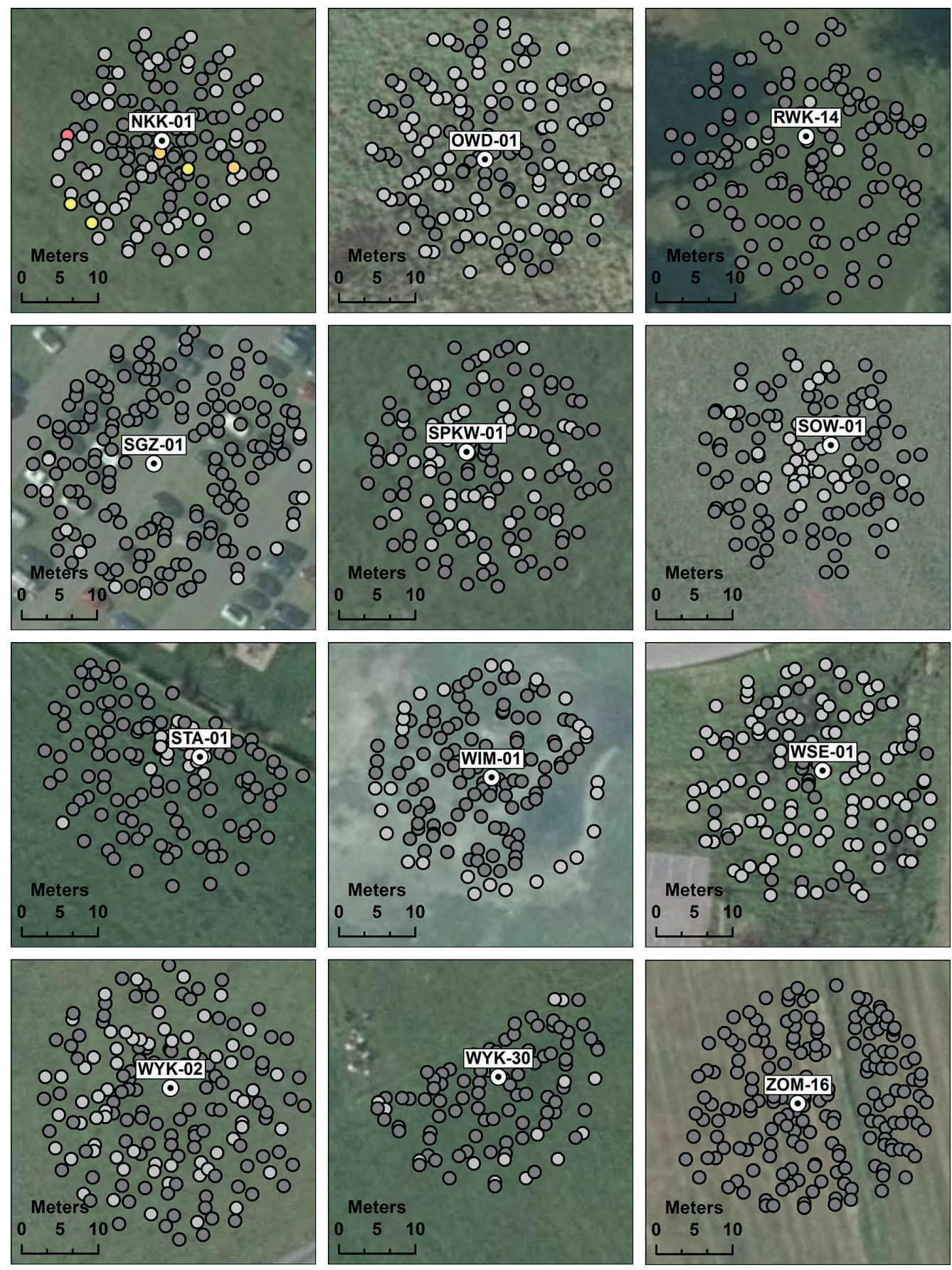

$\mathrm{CH} 4$ concentration [ppmv]

$<1.8 \bigcirc 1.8-2.5 \bigcirc 2.5-10 \bigcirc 10-100 \bigcirc>100$

Figure S1 | Results of the surficial scanning measurements (continued). 


\section{CHAPTER}

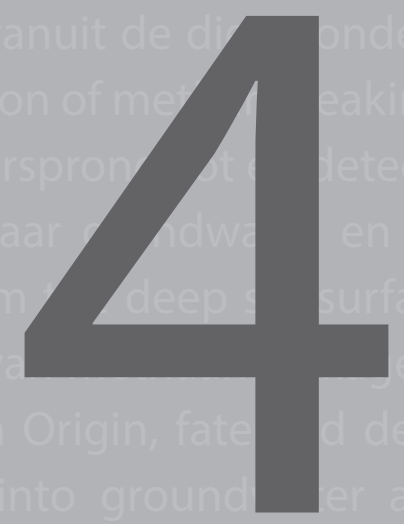

\section{The impact of an historic underground gas well blowout on the current methane chemistry in a shallow groundwater system}

Gilian Schout

Niels Hartog

S. Majid Hassanizadeh Jasper Griffioen 


\section{ABSTRACT}

Blowouts present a small but genuine risk when drilling into the deep subsurface and can have an immediate and significant impact on the surrounding environment. Nevertheless, studies that document their long-term impact are scarce. In 1965, a catastrophic underground blowout occurred during the drilling of a gas well in the Netherlands, which led to the uncontrolled release of large amounts of natural gas from the reservoir to the surface. In this study, the remaining impact on methane chemistry in the overlying aquifers was investigated. Methane concentrations higher than $10 \mathrm{mg} / \mathrm{l}(\mathrm{n}=12)$ were all found to have $\delta^{13} \mathrm{C}-\mathrm{CH}_{4}$ values larger than $-30 \%$ o (VPDB), typical of a thermogenic origin. Both $\delta^{13} \mathrm{C}-\mathrm{CH}_{4}$ and $\delta \mathrm{D}-\mathrm{CH}_{4}$ correspond with the isotopic composition of the gas reservoir. Based on analysis of local groundwater flow conditions, this methane is not a remnant but most likely the result of on-going leakage from the reservoir as a result of the blowout. Progressive enrichment of both $\delta^{13} \mathrm{C}_{-} \mathrm{CH}_{4}$ and $\delta \mathrm{D}-\mathrm{CH}_{4}$ is observed with increasing distance and decreasing methane concentrations. The calculated isotopic fractionation factors of $\varepsilon_{C}=3$ and $\varepsilon_{D}=54$ suggest anaerobic methane oxidation is partly responsible for the observed decrease in concentrations. Elevated dissolved iron and manganese concentrations at the fringe of the methane plume show that oxidation is primarily mediated by the reduction of iron and manganese oxides. Combined, the data reveal the long-term impact that underground gas well blowouts may have on ground water chemistry, as well as the important role of anaerobic oxidation in controlling the fate of dissolved methane.

\section{Significance statement}

The rapid increase in shale gas production in recent years has led to increased attention for its potential negative environmental effects, including the risks of contaminating groundwater with methane and other substances. In this context, the uncontrolled gas migration that is triggered during well blowouts is an understudied environmental hazard. We show that the methane chemistry in shallow groundwater overlying the site of a catastrophic underground blowout continues to be impacted 50 years later. The occurrence of anaerobic methane oxidation limits the spatial extent to which the dissolved thermogenic methane plume could be observed and discerned from local biogenic methane sources. However, it also highlights the requirement to carry out monitoring in close proximity to potential gas leakage sources. 


\section{1 | INTRODUCTION}

Uncontrolled subsurface leaks of natural gas resulting from human underground activities have been shown to occur for several decades (Dyck and Dunn, 1986; Harrison, 1983). However, they became a highly debated subject in recent years after elevated methane concentrations in groundwater were attributed to well-failure of nearby shale gas wells in an area of intense shale gas development (Darrah et al., 2014; Jackson et al., 2013; Osborn et al., 2011). In addition to anthropogenically induced leaks of natural gas to groundwater, conduits for the migration of natural gas may also exist naturally, as evidenced by phenomena such as methane seeps, mud volcanoes and seabed pockmarks (Etiope et al., 2009; Schroot et al., 2005). Leakage of natural gas through a freshwater aquifer can adversely affect groundwater quality by changing redox conditions and increasing pH (Gorody, 2012; Schwartz, 2015). Furthermore, it can result in an explosion and/or asphyxiation hazard (Chilingar and Endres, 2005).

Hydraulically induced fractures have also been investigated for their potential to act as conduits for gas leakage to groundwater (Davies et al., 2012). However, groundwater impacted by gas leakage through hydraulically induced fractures has never been unequivocally identified (Jackson et al., 2014). In contrast, such connections are known to have been generated as a result of gas well blowouts (Tingay et al., 2005). In general, blowouts occur during drilling when unexpectedly high gas pressures are encountered that can no longer be contained. While the frequency of blowouts is relatively low (approximately 1 in a 1000 wells drilled (Patterson et al., 2017)), their potential environmental impact is huge, as evident from high profile cases such as the 'Deepwater Horizon' (Hsieh, 2013) and 'Aliso Canyon' (Conley et al., 2016) blowouts. In some cases, the pressures generated during a blowout do not escape at the surface but form a fracture network that allows the well to blow out underground (Grace, 2003). When these fractures reach to the surface, they may negatively impact the chemistry of shallow groundwater by the massive introduction of methane (Kelly et al., 1985).

In this study, we investigated the long-term effect of an underground blowout on the current methane chemistry in a shallow groundwater system. On December $1^{\text {st }}, 1965$, an underground blowout with a catastrophic outcome occurred near the village of Sleen, the Netherlands. At a depth of 1944 meter below ground level (mbgl) serious well control issues were experienced while drilling well SLN-02 (Figure S1), as a result of an unexpectedly high downhole pressure. Eventually, gas started erupting from a crater that formed several tens of meters away from the spud point. Within forty minutes (during which all personnel evacuated), numerous similar eruptions appeared within a 350 meter radius that coalesced to form a crater that engulfed the entire well pad. Half an hour later, the drilling rig collapsed and eventually sank completely into the ground (Figure 1). A relief well (SLN-03) was spudded on December $16^{\text {th }}$ approximately 600 meter northwest of the blowout (Figure S1). Using deviated drilling, this well was drilled towards the underground location of the blowout. At a depth of 1924 m, hydraulic fracturing was successfully carried out to establish a connection 
with well SLN-02. On February $18^{\text {th }}$, after more than two and a half months of near continuous leakage of large amounts of natural gas, $760 \mathrm{~m}^{3}$ of heavy mud followed by 390 ton of cement were injected into the relief well which eventually caused the blowout to die out.

After the blowout, a network of ground water monitoring wells was installed by the local drinking water production company to monitor for possible adverse effects on groundwater quality at the site of the blowout. For this study, we sampled all relevant monitoring wells. Samples were analyzed for dissolved gas molecular and isotopic composition as well as general groundwater chemistry. Aims of the study were to assess (i) the long-term effects of an underground gas well blowout on dissolved gas concentrations in the shallow aquifer, (ii) the fate of dissolved light hydrocarbons during groundwater transport and (iii) secondary chemical effects of sustained elevated gas concentrations in groundwater.

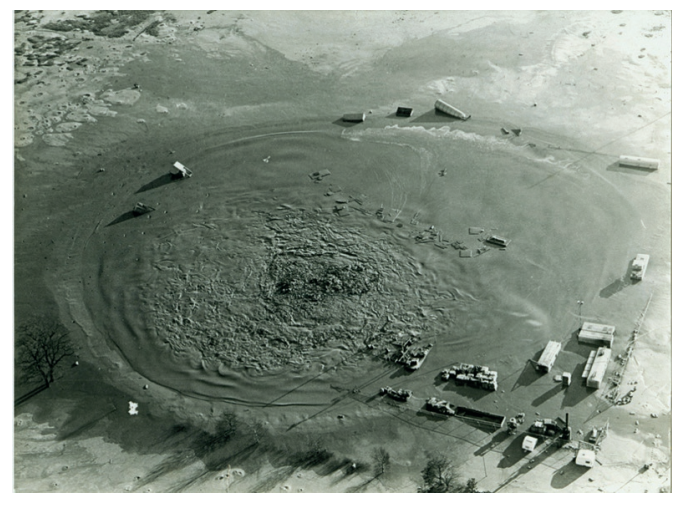

Figure 1 | Aerial photo (Cirkel et al., 2015) of the crater formed by the SLN-02 underground gas well blowout in 1965. Remnants of the well pad and associated trucks and trailers can be seen at the edge of the crater.

\section{2 | HYDROGEOLOGICAL SETTING}

Currently, the site of the blowout is a small parcel of woodland entirely surrounded by pastures (Figure 2). The topography is flat, with surface elevations of 16 - 18 meters above sea level (m-asl). The water table at the location of the blowout varies seasonally between 1 and $2 \mathrm{~m}$ below ground surface ( $\mathrm{m}$-bgs). Based on head measurements in the monitoring wells near the blowout area (Figure 2), the direction of groundwater flow is towards the south and east, with a low hydraulic gradient of roughly 0.25 to $0.50 \mathrm{~m} / \mathrm{km}$. The shallow geology is dominated by a thick succession of Quaternary sands and gravels down to around $120 \mathrm{~m}$ depth (Figure 2). Three main formations are distinguished with increasing depth: the glacial Peelo Formation (fine to medium grained sand), the fluvial Appelscha Formation (coarse sand and gravel) and the marine Oosterhout Formation. The Oosterhout Formation consists of an upper unit of fine to medium grain sand and a lower unit that alternates sandy and clayey deposits. The Dutch National Hydrogeological Model, REGIS II (Vernes and van Doorn, 2005), describes all but the lower Oosterhout clayey unit as having hydraulic conductivities between 10 to $100 \mathrm{~m} / \mathrm{d}$. The Oosterhout formation is underlain by the highly impermeable 
Breda Formation, a clayey, marine, Neogene unit. Together with the aforementioned formations, it is part of the Upper North Sea Group which extends to a depth of around 225 m (Figure S1).

The Sleen gas field consists of a series of Triassic sand- and claystone layers known together as the Main Bundsandstein Subgroup, part of the Lower Germanic Trias Group. Gas is capped in these layers by a more than 100 meter thick deposit of evaporites of the Röt Formation (Figure S1). In total, seven gas wells were drilled in the Sleen municipality. The first exploratory well (SLN-01), drilled in 1950, was abandoned at a depth of around $1000 \mathrm{~m}$ after no hydrocarbons had been encountered. SLN-02 was destroyed in the blowout and SLN-03 was used as the relief well. Wells SLN-04 up to SLN-07 (Figure 2) were drilled between 1975 and 1980. Gas was produced from the aforementioned Triassic sandstones of the Bundsandstein Group. However, it was found that the reservoir was highly compartmentalized due to fracturing. Hence, production was halted after only $40 \%$ of the total gas in the reservoir had been produced (Winngsplan Zuid-Oost Drenthe, 2003). Chemical and carbon isotopic composition of gas produced from the Sleen field is available through the analyses of samples from wells SLN-04, SLN-05 and SLN-07, carried out in the early 2000s (Table S1). Notably, the average mole fraction of nitrogen in gas samples from the Sleen field is very high at $53.7 \%$, while that of methane is $44.7 \%$. Average $\delta^{13} \mathrm{C}-\mathrm{CH}_{4}$ of the three samples was $-22.1 \%$ o $\left(\delta \mathrm{D}-\mathrm{CH}_{4}\right.$ was not analyzed).
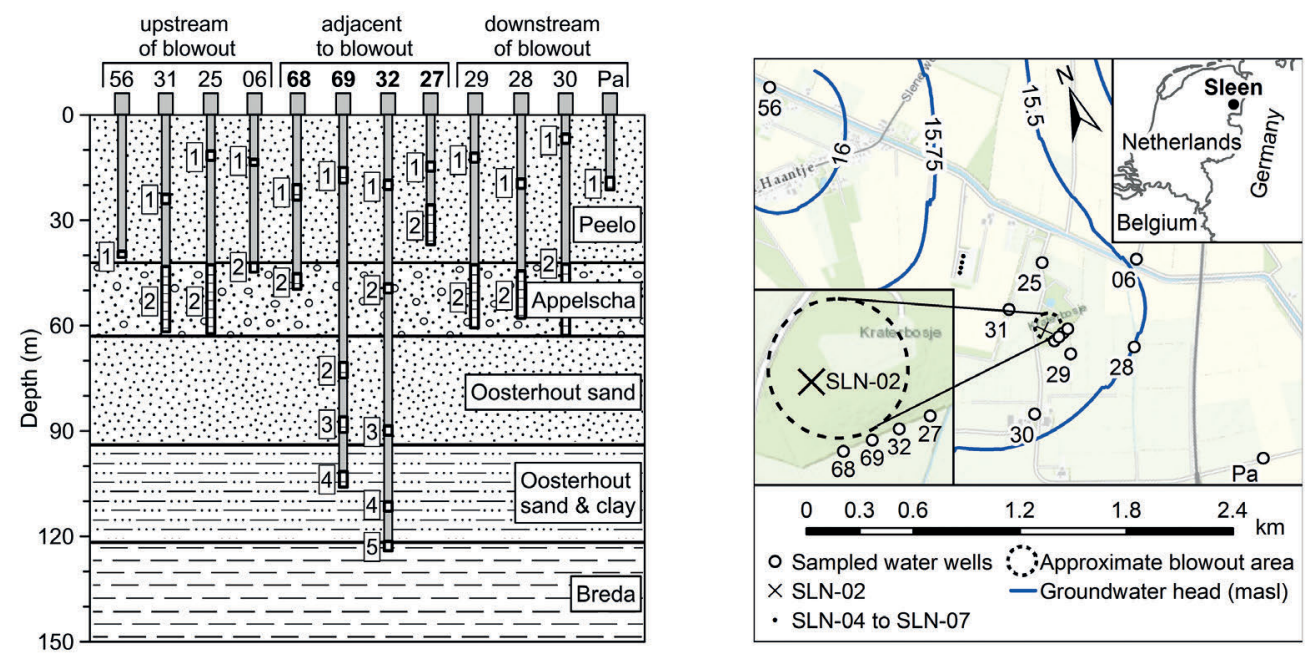

Figure 2 | Left: shallow stratigraphy showing the dominant lithology of each formation as well as the approximate location, depth, length and designation of each wellbore and individual monitoring well. Right: Topographic map showing the location of the groundwater monitoring wells sampled for this study as well as the spud point of the blowout well (SLN-02) and other nearby gas wells. Blue lines signify hydraulic head contours. 


\section{3 | METHODS}

Groundwater samples were collected between January and April 2016 from 12 nested and 2 individual groundwater monitoring wells. The nested wells each have between 2 to 5 individual groundwater monitoring wells screened at different depths in the same wellbore (Figure 2) and are backfilled with impermeable clays both above and below screened intervals as well as at the depth of natural clay layers to ensure hydraulic isolation. Hence, a total of 27 unique groundwater samples could be collected. Samples were collected using peristaltic pumps. Wells were purged prior to sampling until around three times the total volume of water in the well tube had been flushed. Samples were only collected after the temperature, $\mathrm{pH}$ and electrical conductivity of the water had stabilized and dissolved oxygen indicated stable anoxic conditions. Samples were stored at $5^{\circ} \mathrm{C}$ until analysis. Samples were filtered through $0.45-\mu \mathrm{m}$ pore filters. Major ion and cations were determined using ion chromatography (IC) and inductively coupled plasma optical emission spectrometry (ICPOES), respectively. Samples for ICP-OES analysis were acidified using $\mathrm{HNO}_{3}$. Alkalinity was determined using titration with sulfuric acid and ammonium concentrations using a photo spectrometer.

Isoflasks ${ }^{\circledR}$ were used to sample water for the analyses of dissolved gas chemical and isotopic composition. These were directly connected to the tubing of the peristaltic pump, minimizing gas losses to the atmosphere. Samples were analyzed by Isolab, the Netherlands, for gas composition ( $\mathrm{C} 1$ to $\mathrm{C} 5, \mathrm{C} 5+, \mathrm{N}_{2}, \mathrm{CO}_{2}, \mathrm{O}_{2}, \mathrm{Ar}$ ) as well as the following stable isotope ratios: $\delta^{13} \mathrm{C}_{-} \mathrm{CH}_{4^{\prime}} \delta^{13} \mathrm{C}-\mathrm{C}_{2} \mathrm{H}_{6^{\prime}}, \delta^{13} \mathrm{C}_{-} \mathrm{C}_{3} \mathrm{H}_{8^{\prime}} \delta^{2} \mathrm{H}-\mathrm{CH}_{4}$ and $\delta^{13} \mathrm{C}-\mathrm{CO}_{2}$. Isotopic compositions of carbon and hydrogen are reported relative to PDB and SMOW standards, respectively, using the standard delta notations (40). The composition of samples was analyzed on an Agilent 6890N/7890A/7890B Gas Chromatograph (GC). Carbon isotopes of methane were analyzed with an Agilent 6890N GC interfaced to a Finigan Delta S isotope-ratio mass spectrometer (IRMS). Carbon isotopes of $C_{2}$ and $C_{3}$ as well as hydrogen isotopes of $C_{1}$ were analyzed on an Agilent 7890A GC interfaced to a MAT 253 IRMS.

Samples were allowed to equilibrate to the temperature and pressure of the laboratory. For samples from 06-1, 25-1 and 25-2 (Figure 2), collected in January 2016, three Isoflasks were used per well and the pure headspace gas was used for analysis. All available headspace gas was used up to do the full suite of analyses. Hence, no gas remained for duplicate measurements. For subsequent samples, the method was slightly altered by introducing $10 \mathrm{ml}$ of helium into the headspace of the Isoflasks at the laboratory, after which they were allowed to equilibrate. Subsequently, the total headspace gas was extracted and using a syringe. The total water volume was determined by weighing the samples. Meanwhile, the pressure and temperature in the laboratory were recorded which gives a value for Henry's Law constant. This was then used to calculate the original mass concentration of gas components in the aqueous phase of the original sample. 


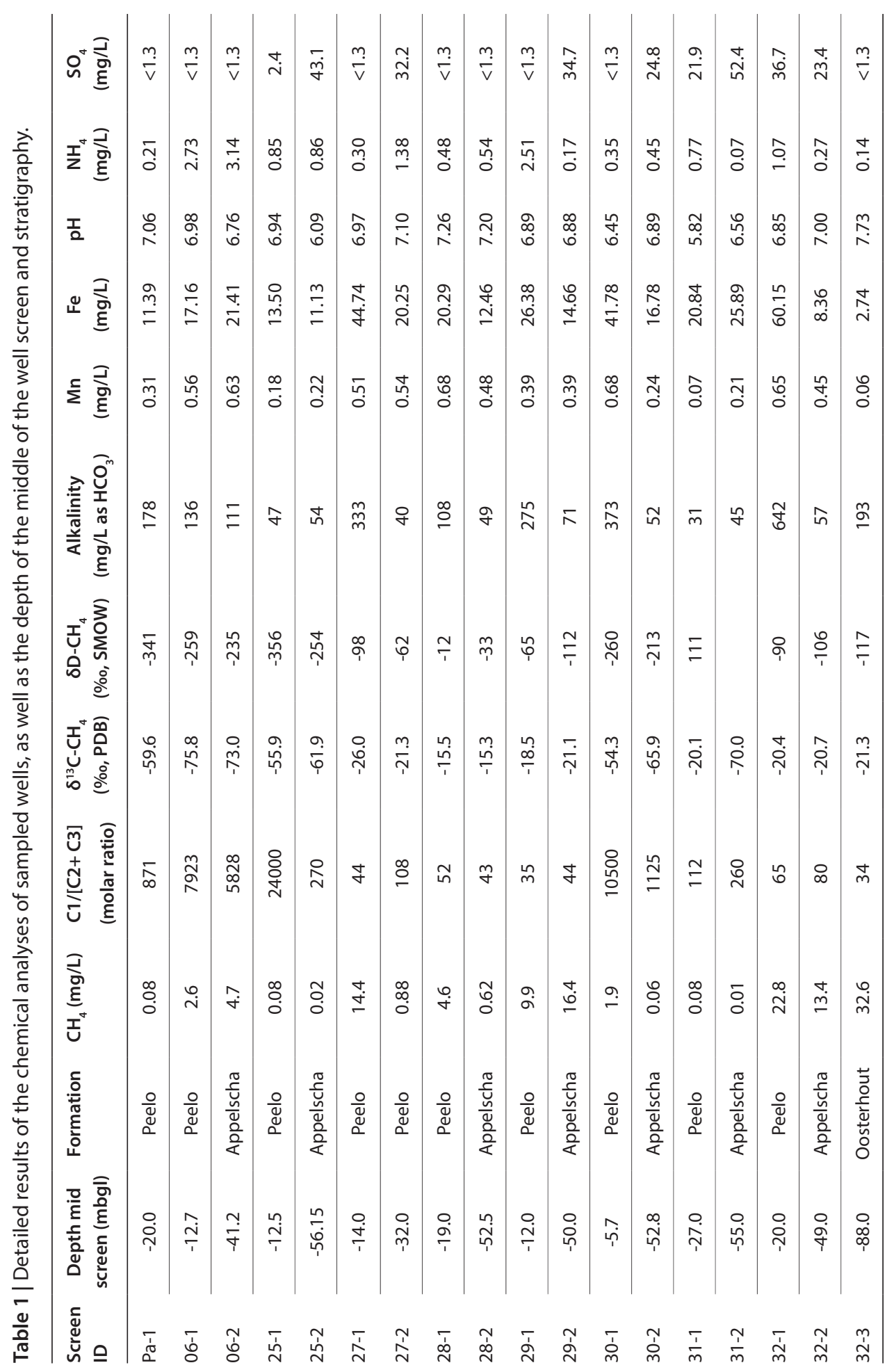




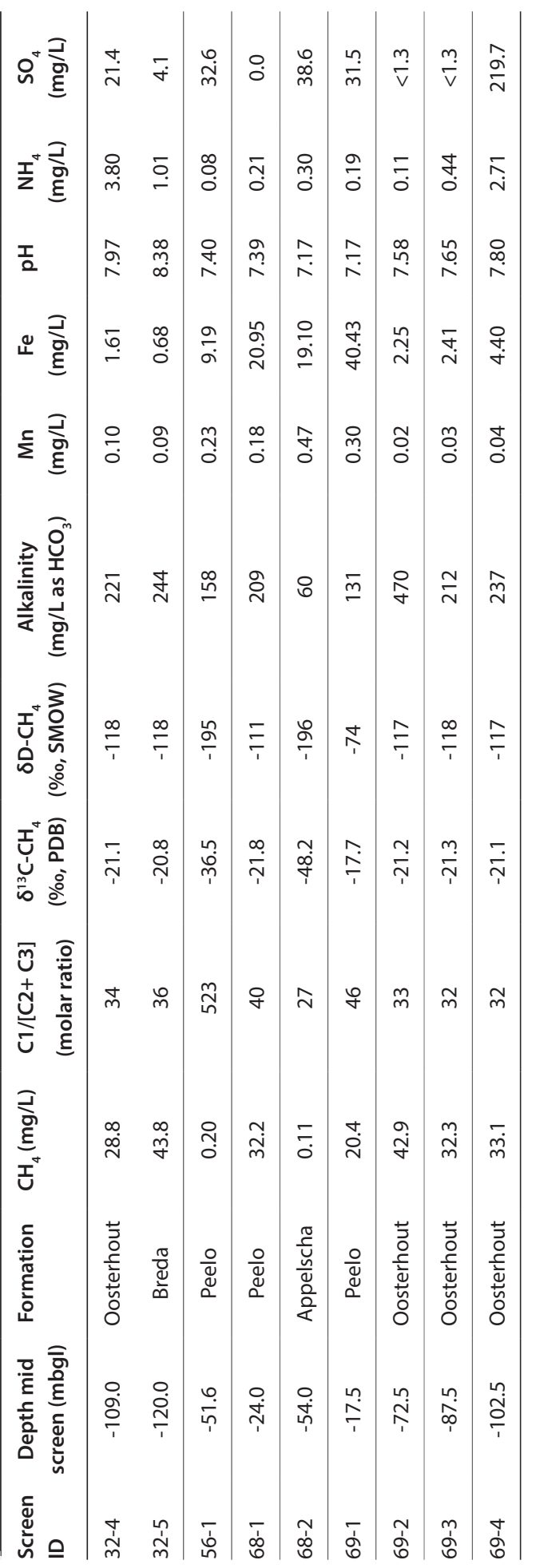


Using this methodology, only one Isoflask ${ }^{\circledR}$ was needed for the full suite of analyses. Nevertheless, at least two Isoflasks ${ }^{\circledR}$ were collected per well such that duplicate analyses were done for all but the three initially sampled wells. Where duplicate or triplicate analyses were available, average concentrations and isotopic compositions are reported in this paper. Mean and median coefficient of variation (CV) for duplicate measurements of methane mass concentration were found to be $4.3 \%$ and $2.2 \%$, respectively. The mean and median difference between the $\delta^{13} \mathrm{C}_{-}-\mathrm{CH}_{4}$ of duplicate measurements was $0.39 \%$ and $0.10 \%$, respectively. For $\delta \mathrm{D}-\mathrm{CH}_{4^{\prime}}$ this was $0.14 \%$ and $0.10 \%$. To estimate the temporal variability and consistency of measured methane concentrations and isotopic composition, two wells were re-sampled in June of 2016. Results showed acceptable variations in dissolved gas concentrations as well as isotopic composition (Table S2).

\section{4 | RESULTS AND DISCUSSION}

Minimum and maximum observed methane concentrations in the groundwater monitoring wells near the blowout were 0.01 and $43.8 \mathrm{mg} / \mathrm{l}$, respectively (Table 1). The highest methane concentrations were found in the monitoring wells directly adjacent to the blowout area. Although no threshold levels for safe concentrations of methane in groundwater have been set in The Netherlands, methane concentrations in twelve of the sampled monitoring wells exceeded the recommended $10 \mathrm{mg} / \mathrm{L}$ hazard threshold level set by the US Department of the Interior (Eltschlager et al., 2001). Of these twelve wells, seven exceeded the $28 \mathrm{mg} / \mathrm{L}$ hazard mitigation level. As methane concentrations up to $100 \mathrm{mg} / \mathrm{L}$ have been shown to occur naturally in Dutch groundwater (Fortuin and Willemsen, 2005), concentrations alone were not sufficient for determining the origin of dissolved methane. Isotopic characterization showed that all samples with concentrations greater than $10 \mathrm{mg} / \mathrm{l}(\mathrm{n}=12)$ had a $\delta^{13} \mathrm{C}_{-} \mathrm{CH}_{4}$ above $-30 \%$ (Figure 3), typical of a thermogenic origin. Biogenic methane $\left({ }^{13} \mathrm{C}-\mathrm{CH}_{4}<-50 \%\right.$ ) in concentrations higher than $1 \mathrm{mg} / \mathrm{L}$ was only encountered in three monitoring wells up-gradient of the blowout (wells 06-1, 06-2 and 30-1 with concentrations of 2.55, 4.69 and $1.89 \mathrm{mg} / \mathrm{L}$, respectively). Supporting the biogenic origin of methane in these samples are the elevated ammonium concentrations (Figure S2), a common by-product during methanogenic decomposition of organic matter (Griffioen et al., 2013).

The maximum distance at which dissolved thermogenic methane was identified is 515 meter down-gradient of the location of the blowout well, in both monitoring wells 28-1 and 28-2 (Figure 2). This suggests that dissolved methane travelled with a minimum effective velocity of $10 \mathrm{~m} / \mathrm{yr}$ in both the Peelo and the Appelscha formations. One kilometer further down-gradient, at monitoring well Pa (Figure 2), the groundwater appears to be unaffected by the blowout. However, this well is screened in the Peelo formation and not the more conductive Appelscha formation, where methane contamination could have travelled farther. Assuming a hydraulic conductivity of $100 \mathrm{~m} / \mathrm{d}$ and porosity of 0.3 , groundwater in this formation is estimated to have an average velocity of $30 \mathrm{~m} / \mathrm{yr}$, given the hydraulic 
head gradient of around $0.25 \mathrm{~m} / \mathrm{km}$. Methane concentrations in monitoring wells 25 and 31 (located 230 and $383 \mathrm{~m}$ up-gradient of the blowout well, respectively) are less than $0.1 \mathrm{mg} / \mathrm{L}$. This shows that although lateral free gas migration may have occurred during the blowout, this does not contribute significantly to the observed present-day distribution of methane concentrations. Such two-phase gas migration would be largely independent of the direction of the low hydraulic gradient and hence occur in all directions equally.

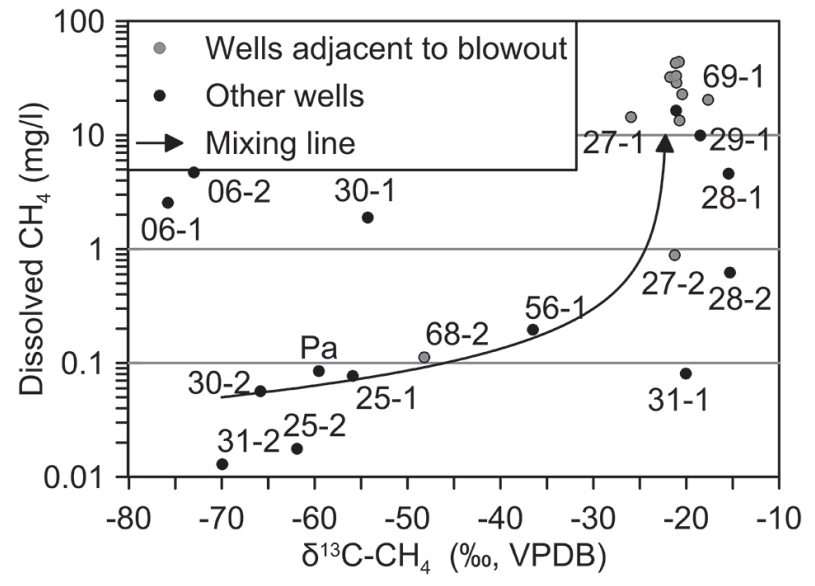

Figure 3. Carbon isotope ratio vs. dissolved methane concentration. Samples labeled with grey dots are from the four wells located directly adjacent to the approximate location of the crater $(68,69,32,27$, Figure 1). Mixing line is calculated with a biogenic $(0.05 \mathrm{mg} / \mathrm{l} ;-70 \%$ ) and thermogenic (10 mg/L; -22\%o) endmember.

There was no visually recognizable methane seepage at ground surface. However, the fact that methane concentrations are still highest in the wells directly adjacent to the location of the crater formed by the blowout (Figure 3) suggests that leakage from the reservoir is still ongoing. Otherwise, with the estimated effective velocity of $30 \mathrm{~m} / \mathrm{yr}$ in the Appelscha formation it is likely that any dissolved methane released during the blowout event would have been transported beyond the monitoring wells during the past 50 years. Also, the phreatic sandy nature of the shallow groundwater system studied precludes the conditions for secondary gas accumulations. In addition, a recent field experiment (Cahill et al., 2017) in which gas-phase methane was injected into a shallow sedimentary aquifer illustrated that residual methane was dissolved in timescale of months, not years. Alternatively, matrix diffusion of aqueous methane from the Oosterhout or Breda clays (Figure 2) due to underlying secondary gas entrapment might be the origin of thermogenic methane in the shallow groundwater system. However, such a process would yield strictly increasing dissolved methane concentrations with depth, which is not observed (Table 1).

Hence, we argue that the most plausible explanation for the elevated concentrations of thermogenic methane found in the shallow groundwater system overlying the location of a blowout is that gas-phase methane leakage from a deeper thermogenic gas source continues to this day. Whether or not that source is the primary source from which the blowout occurred 
or secondarily formed gas entrapments is unknown. However, the perturbation of the sedimentary sequence due to the blowout would have negatively impacted the likelihood of secondary gas accumulations. Therefore, ongoing leakage of thermogenic methane directly from the Sleen gas reservoir from which the blowout occurred is considered most likely.

The combination of molecular composition $\left(C_{1} /\left[C_{2}+C_{3}\right]\right.$ ratio) and methane carbon isotope ratio found in the majority of water wells adjacent to the blowout indeed closely resembles that of the samples from the Sleen reservoir (Figure 4). Additionally, a subset of samples fall within a range of values that can be explained by mixing of biogenic methane formed in-situ with thermogenic methane from the Sleen reservoir. Higher $C_{1} /\left[C_{2}+C_{3}\right]$ ratios than that of the reservoir are observed in a number of samples with thermogenic methane. This molecular fractionation could be due the differential solubility and sorption characteristics of methane and higher alkanes (Etiope et al., 2009). Such 'solubility fractionation' was used to explain elevated $C_{1} / C_{2}$ ratios of thermogenic methane in groundwater in West Virginia, USA (Harkness et al., 2017). Alternatively, molecular fraction may occur as a result of the preferential oxidation of non-methane alkanes (Musat, 2015; Sassen et al., 2004). Partial oxidation of dissolved ethane should leave the residual ethane enriched in ${ }^{13} \mathrm{C}^{1} \mathrm{C}_{2} \mathrm{H}_{6^{\prime}}$ as the lighter ${ }^{12} \mathrm{C}$ is preferentially consumed. Indeed, several thermogenic samples with elevated $\mathrm{C}_{1} /\left[\mathrm{C}_{2}+\mathrm{C}_{3}\right]$ ratios were found to have enriched $\delta^{13} \mathrm{C}-\mathrm{C}_{2} \mathrm{H}_{6^{\prime}}$ giving credence to this hypothesis (Figure S3).

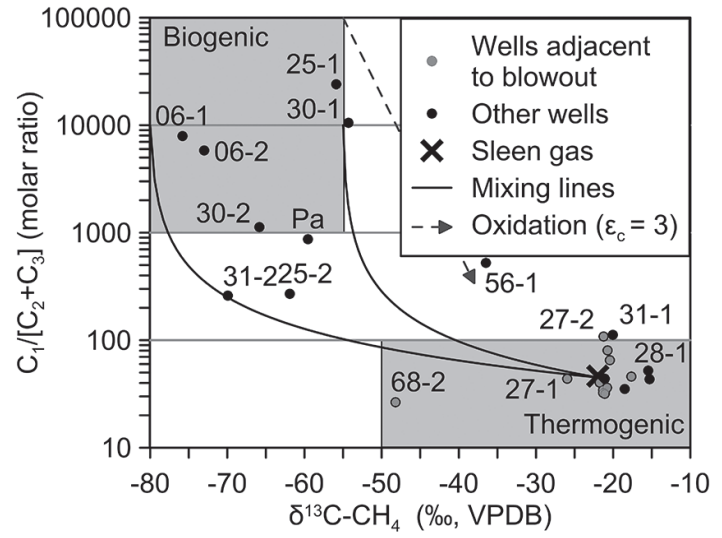

Figure $4 \mid \mathrm{C}_{1} /\left(\mathrm{C}_{2}+\mathrm{C}_{3}\right)$ vs. $\delta^{13} \mathrm{C}-\mathrm{CH}_{4}$ of analyzed groundwater wells. Mixing lines are between a thermogenic (average value of the three available samples from the Sleen gas field) and two possible biogenic $\left(C_{1} /\left(C_{2}+C_{3}\right)\right.$ of 10,000 and $\delta^{13} C$ of $-80 \%$ and $-55 \%$ ) end members. Oxidation calculated according to equations in ref. (Whiticar, 1999).

The relation between $\delta{ }^{13} \mathrm{C}-\mathrm{CH}_{4}$ and $\delta \mathrm{D}-\mathrm{CH}_{4}$ indicates that a number of groundwater samples were significantly enriched in both carbon and hydrogen isotopic compositions (Figure 5). Most notably, wells 29 and 28 (which lie directly down-gradient of the blowout well at a distance of 201 and 515 meter, respectively) showed progressive isotopic enrichment along with decreasing methane concentrations, indicating degradation. Since conditions are anoxic, this enrichment is likely the result of anaerobic methane oxidation (AOM) (Van Stempvoort et al., 2005), a process which could potentially limit the extent of a groundwater 
methane plume (Roy et al., 2016). Isotopic fractionation factors of methane can be quantified as a function of the amount of residual (non-oxidized) methane using the classical Rayleigh fractionation equation, which can be rewritten as (Whiticar, 1999);

$$
\delta^{13} C\left(\mathrm{CH}_{4}\right)_{t}=\delta^{13} \mathrm{C}\left(\mathrm{CH}_{4}\right)_{i}-\varepsilon_{C} \cdot \ln (f)
$$

where $\int$ is the residual methane fraction, $\varepsilon_{\mathrm{c}}$ is the kinetic isotopic fractionation factor and

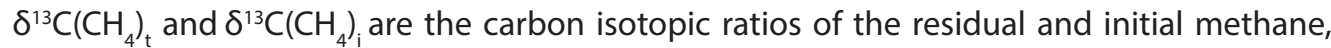
respectively, and similarly for deuterium enrichment.

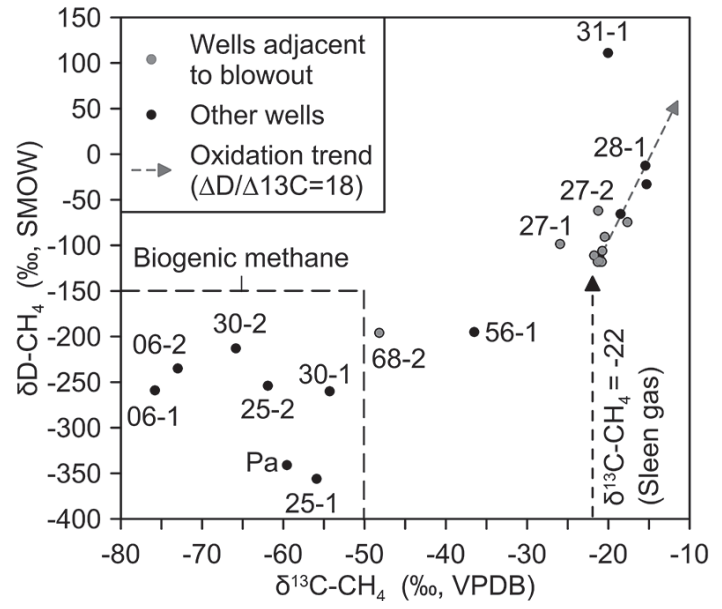

Figure $5 \mid \delta{ }^{13} \mathrm{C}_{-}-\mathrm{CH}_{4}$ vs. $\delta \mathrm{D}-\mathrm{CH}_{4}$ of analyzed groundwater wells. The grey arrow represents the calculated (according to ref. (Whiticar, 1999)) isotopic enrichment due to $\mathrm{AOM}$ with $\varepsilon_{\mathrm{C}}=3$ and $\varepsilon_{\mathrm{D}}=54\left(\Delta \mathrm{D} / \Delta^{13} \mathrm{C}=18\right)$. In the absence of $\delta \mathrm{D}-\mathrm{CH}_{4}$ analyses from the Sleen gas field, the black arrow shows the $\delta^{13} \mathrm{C}-\mathrm{CH}_{4}$ of Sleen gas.

Figure 6 shows that a reasonable fit was achieved with $\varepsilon_{C}=3$ and $\varepsilon_{D}=54$ and an initial isotopic composition of $\delta^{13} \mathrm{C}=-22 \%$ and $\delta \mathrm{D}$ of $-130 \%$ o. Due to the uncertainty in travel time of the methane towards individual well screens, as well as mixing with unknown proportions of biogenic methane, some deviation from the modelled line is expected. Calculated fractionation factors fall within the low end of the reported range for anaerobic microbial methane oxidation (Whiticar, 1999). The relatively low fractionation factors could in part be due to the diluting effect of dispersion on the decreasing methane concentrations during transport with ground water flow, which does not affect the isotopic composition. In addition, however, the low fractionation factors could possibly be due to iron oxide mediated AOM, as this oxidation pathway results in lower fraction factors than for sulfate coupled AOM (Egger et al., 2015). The resulting ratio of carbon versus deuterium enrichment $\left(\triangle D / \Delta^{13} C\right)$ was found to be 18 (Figure 5), which falls within the wide range of values for AOM coupled to the reduction of both sulfate and iron oxides as derived from a limited amount of available studies (Coleman et al., 1981; Egger et al., 2015; Whiticar, 1999). 


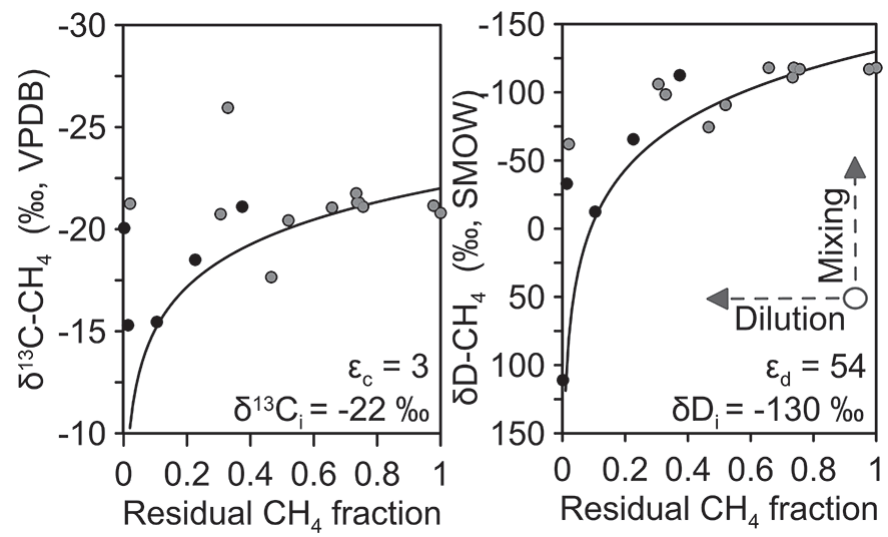

Figure $6 \mid$ Percentage of residual methane versus $\delta{ }^{13} \mathrm{C}_{-} \mathrm{CH}_{4}$ (left) and $\delta \mathrm{D}-\mathrm{CH}_{4}$ (right). Isotopic fractionation as a result of $\mathrm{AOM}$ was modeled using equation 1 . Residual methane fractions were calculated as a function of the maximum observed methane concentration ( $43.8 \mathrm{mg} / \mathrm{L}$ in well $32-5$ ). Best fit was achieved with fractionation factors of $\varepsilon_{c}=3$ and $\varepsilon_{D}=54$ and initial isotopic compositions of $\delta{ }^{13} \mathrm{C}_{-} \mathrm{CH}_{4}=-22 \%$ and $\delta \mathrm{D}-\mathrm{CH}_{4}=-130 \%$. The four wells adjacent to the blowout are indicated with grey circles, all other wells with black circles.

Methane oxidation coupled to sulfate, iron oxides or manganese oxides is described by the following net reactions (Beal et al., 2009), respectively:

$$
\begin{gathered}
\mathrm{CH}_{4}+4 \mathrm{MnO}_{2}+7 \mathrm{H}^{+} \rightarrow \mathrm{HCO}_{3}^{-}+4 \mathrm{Mn}^{2+}+5 \mathrm{H}_{2} \mathrm{O} \\
\mathrm{CH}_{4}+8 \mathrm{Fe}(\mathrm{OH})_{3}+15 \mathrm{H}^{+} \rightarrow \mathrm{HCO}_{3}^{-}+8 \mathrm{Fe}^{2+}+21 \mathrm{H}_{2} \mathrm{O} \\
\mathrm{CH}_{4}+\mathrm{SO}_{4}^{2-} \rightarrow \mathrm{HCO}_{3}^{-}+\mathrm{HS}^{-}+\mathrm{H}_{2} \mathrm{O}
\end{gathered}
$$

Elevated alkalinities are associated with all three pathways and were indeed encountered in a subset of wells with elevated methane concentrations (Figure S2). While AOM coupled to sulfate reduction has frequently been described in groundwater systems (Kelly et al., 1985; Timmers et al., 2016; Van Stempvoort et al., 2005), sulfate concentrations appear to be unrelated to methane concentrations (Figure S2). Instead, both iron and manganese concentrations are elevated in wells with intermediate methane concentrations ( 1 to $20 \mathrm{mg} / \mathrm{L}$ ) indicating that the reduction of iron and manganese oxides is the predominant AOM pathway (Figure 7). The lower iron and manganese concentrations in the wells with the highest methane concentrations in the vicinity of the blowout area show that reactive iron and manganese oxides have become depleted. These more reduced conditions might locally allow AOM coupled to sulfate reduction to become more dominant.

The depletion of iron and manganese oxides in the wells directly downgradient from the blowout zone highlights the fact that while AOM plays an important role in controlling the fate of dissolved methane, it is ultimately limited by the initial availability of iron and manganese oxides in the aquifer sediments. As precipitation of siderite $\left(\mathrm{FeCO}_{3}\right)$ and 
rhodochrosite $\left(\mathrm{MnCO}_{3}\right)$ likely occurs simultaneously with reduction, using the aqueous Fe and $\mathrm{Mn}$ concentrations to calculate a rate of oxidation would lead to an underestimation of the actual oxidation rate (Van Breukelen et al., 2004). Increased manganese concentrations are observed at lower methane concentrations than increased iron concentrations (i.e. at the fringe of the plume). This could be due to AOM coupled to the reduction of manganese oxides being thermodynamically more favorable than AOM coupled to the reduction of iron oxides, when the concentrations of the relevant aquatic species involved are near-identical (Beal et al., 2009; Stumm and Morgan, 1996).
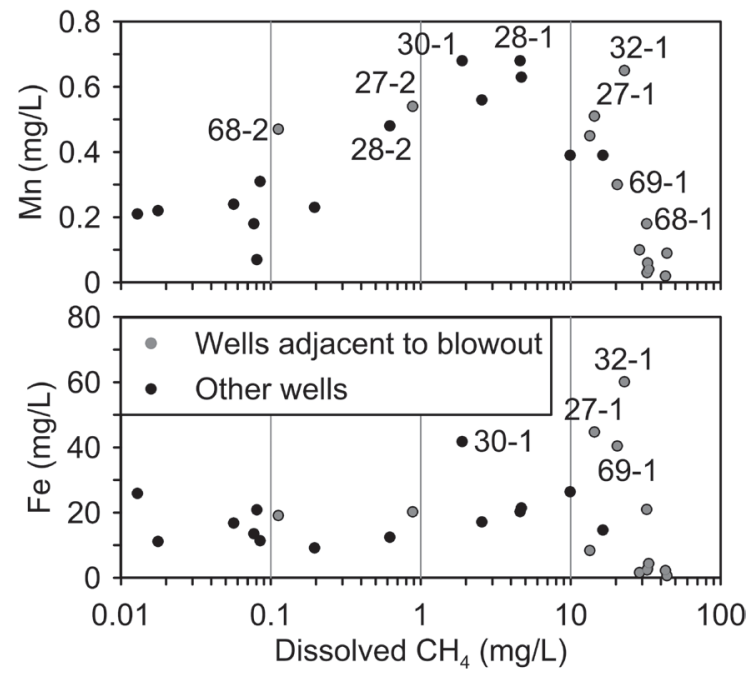

Figure 7 | Dissolved methane concentrations plotted against concentrations of manganese and iron for all sampled wells.

Given the complexity of the biogeochemical process, interpretation in terms of zero-order or first-order degradation is inexact. Nevertheless, a tentative assessment of the rate oxidation can be made based on the observed methane concentrations along the 515 meter transect from the location of blowout well SLN-02 past monitoring wells 32-1, 29-1 and 28-1. Neglecting the influence of hydrodynamic dispersion on the attenuation of methane concentrations along this transect and assuming a flow velocity of $10 \mathrm{~m} / \mathrm{yr}$ to each of these wells yields a rate of oxidation of $0.38 \mathrm{mg} /$ (L.year) (Figure S4). While rates of AOM in freshwater environments are still poorly constrained, this calculated rate is much lower than the average rate of oxidation of $117 \mathrm{mg} /(\mathrm{L} . \mathrm{yr})$ observed in a recent study of AOM in freshwater wetlands (Segarra et al., 2015). This shows that, at least theoretically, the near complete disappearance of methane along the $500 \mathrm{~m}$ flow path can be attributed to AOM.

The occurrence of methane oxidation in stray gas impacted groundwater has important implications for groundwater monitoring programs aimed at uncovering natural and anthropogenic sources of gas leakage. Here, the maximum distance down-gradient of the blowout at which thermogenic methane was detected is approximately $500 \mathrm{~m}$ and is limited by the occurrence of methane oxidation. Hence, while stray gas migration may occur over much greater distances in other hydrogeological circumstances (Llewellyn et 
al., 2015), monitoring should ideally occur in close proximity to possible leakage sources. In addition, the occurrence of methane oxidation causes enrichment of methane isotopic composition which could lead to false positive detections of thermogenic methane. A good example thereof is presented by well 56-1 in this study. This well was expected to contain biogenic methane, given that it is located approximately $2 \mathrm{~km}$ up-gradient of the blowout. In the absence of knowledge about the composition of leaked gas and local redox conditions, its $\delta^{13} \mathrm{C}$ and $\delta \mathrm{D}$ values of $-36.5 \%$ and $-195.0 \%$ would typically be considered thermogenic. However, the unusual isotopic composition of methane in the water from well 56-1 is likely the result of microbial oxidation of biogenic methane (Figure 4).

\section{5 | CONCLUSIONS}

Fifty years after the catastrophic underground blowout that occurred near the village of Sleen, The Netherlands, a detailed investigation of the groundwater chemistry was carried out in the shallow aquifer overlying the blowout location. This study led to the following conclusions;

(i) Dissolved methane concentrations in wells close to the location of the blowout are highly elevated (up to $44 \mathrm{mg} / \mathrm{L}$ ) compared to those in background wells. Methane in concentrations greater than $10 \mathrm{mg} / \mathrm{L}$ is thermogenic and originates from the Sleen reservoir at $2 \mathrm{~km}$ below ground surface.

(ii) Most likely, the long-term persistence of elevated methane concentrations adjacent to the blowout site is the result of continuing gas leakage form the Sleen reservoir initiated by the blowout.

(iii) Anaerobic methane oxidation coupled to the reduction of iron and manganese oxides plays a major role in the natural attenuation of the dissolved methane plume. However, the oxidation capacity is limited by the availability of iron and manganese oxides in the aquifer sediments which is resulting in a slowly expanding methane plume.

(iv) Considering the potential impact of methane oxidation, monitoring for gas contamination should be conducted in close proximity to potential gas leakage sources, and at multiple monitoring locations. Relying on single sampling points may lead to false non-detects if the monitoring distance is too large. In addition, the compositional and isotopic impact of oxidation may lead to erroneous assessment of the origin of dissolved gasses, especially when $\delta^{13} \mathrm{C}$ is analyzed without $\delta D$.

\section{Acknowledgements}

This work is part of the research program 'Shale Gas \& Water' with project number 859.14.001, which is financed by the Dutch Research Council (NWO). Furthermore, we acknowledge the 'Watermaatschappij Drenthe' (WMD) for providing access to their groundwater monitoring wells and facilitating the groundwater sampling campaign. Lastly, we acknowledge the Royal Dutch Shell for providing results of the analyses of gas samples from the Sleen gas field. 


\section{REFERENCES}

Beal, E.J., House, C.H., Orphan, V.J., 2009. Manganese- and Iron-Dependent Marine Methane Oxidation. Science (80-. ). 325, 184-187. https://doi.org/10.1126/science.1169984

Cahill, A.G., Steelman, C.M., Forde, O., Kuloyo, O., Emil Ruff, S., Mayer, B., Ulrich Mayer, K., Strous, M., Cathryn Ryan, M., Cherry, J.A., Parker, B.L., 2017. Mobility and persistence of methane in groundwater in a controlled-release field experiment. Nat. Geosci. https://doi.org/10.1038/ ngeo2919

Chilingar, G. V., Endres, B., 2005. Environmental hazards posed by the Los Angeles Basin urban oilfields: An historical perspective of lessons learned. Environ. Geol. https://doi.org/10.1007/s00254004-1159-0

Cirkel, G., Hartog, N., De La, B., Gonzalez, L., Stuyfzand, P., 2015. Methaan in ondiep Nederlands grondwater: verbinding met de diepe ondergrond? $\mathrm{H} 2 \mathrm{O}$.

Coleman, D.D., Risatti, J.B., Schoell, M., 1981. Fractionation of carbon and hydrogen isotopes by methaneoxidizing bacteria. Geochim. Cosmochim. Acta 45, 1033-1037. https://doi.org/10.1016/00167037(81)90129-0

Conley, S., Franco, G., Faloona, I., Blake, D.R., Peischl, J., Ryerson, T.B., 2016. Methane emissions from the 2015 Aliso Canyon blowout in Los Angeles, CA. Science (80-. ). 351, 1317-1320. https://doi. org/10.1126/science.aaf2348

Darrah, T.H., Vengosh, A., Jackson, R.B., Warner, N.R., Poreda, R.J., 2014. Noble gases identify the mechanisms of fugitive gas contamination in drinking-water wells overlying the Marcellus and Barnett Shales. Proc. Natl. Acad. Sci. 111, 14076-14081. https://doi.org/10.1073/ pnas.1322107111

Davies, R.J., Mathias, S.A., Moss, J., Hustoft, S., Newport, L., 2012. Hydraulic fractures: How far can they go? Mar. Pet. Geol. 37, 1-6.

Dyck, W., Dunn, C.E., 1986. Helium and methane anomalies in domestic well waters in southwestern Saskatchewan, Canada, and their relationship to other dissolved constituents, oil and gas fields, and tectonic patterns. J. Geophys. Res. Solid Earth 91, 12343-12353. https://doi.org/10.1029/ JB091iB12p12343

Egger, M., Rasigraf, O., Sapart, C.J., Jilbert, T., Jetten, M.S.M., Röckmann, T., Van Der Veen, C., Bânda, N., Kartal, B., Ettwig, K.F., Slomp, C.P., 2015. Iron-mediated anaerobic oxidation of methane in brackish coastal sediments. Environ. Sci. Technol. 49, 277-283. https://doi.org/10.1021/ es503663z

Eltschlager, K.K., Hawkins, J.W., Ehler, W.C., Baldassare, F.J., 2001. Technical Measures for the Investigation and Mitigation of Fugitive Methane Hazards in Areas of Coal Mining. U.S. Dep. Inter. Off. Surf. Min. 129 pp.

Etiope, G., Feyzullayev, A., Baciu, C.L., 2009. Terrestrial methane seeps and mud volcanoes: A global perspective of gas origin. Mar. Pet. Geol. 26, 333-344.

Fortuin, N.P.M., Willemsen, A., 2005. Exsolution of nitrogen and argon by methanogenesis in Dutch ground water. J. Hydrol. 301, 1-13.

Gorody, A.W., 2012. Factors affecting the variability of stray gas concentration and composition in groundwater. Environ. Geosci. 19, 17-31. https://doi.org/10.1306/eg.12081111013

Grace, R.D., 2003. Blowout and well control handbook. Gulf Professional Pub. 
Griffioen, J., Vermooten, S., Janssen, G., 2013. Geochemical and palaeohydrological controls on the composition of shallow groundwater in the Netherlands. Appl. Geochemistry 39, 129-149. https://doi.org/10.1016/j.apgeochem.2013.10.005

Harkness, J.S., Darrah, T.H., Warner, N.R., Whyte, C.J., Moore, M.T., Millot, R., Kloppman, W., Jackson, R.B., Vengosh, A., 2017. The Geochemistry of Naturally Occurring Methane and Saline Groundwater in an Area of Unconventional Shale Gas Development. Geochim. Cosmochim. Acta 208, 302 334. https://doi.org/http://doi.org/10.1016/j.gca.2017.03.039

Harrison, S.S., 1983. Evaluating System for Ground-Water Contamination Hazards Due to Gas-Well Drilling on the Glaciated Appalachian Plateau. Groundwater 21, 689-700. https://doi. org/10.1111/j.1745-6584.1983.tb01940.x

Hsieh, P.A., 2013. Application of MODFLOW for oil reservoir simulation during the Deepwater Horizon crisis. Ground Water 49, 319-323. https://doi.org/10.1111/j.1745-6584.2011.00813.x

Jackson, R.B., Vengosh, A., Carey, J.W., Davies, R.J., Darrah, T.H., Sullivan, F.O., Gabrielle, P., 2014. The Environmental Costs and Benefits of Fracking. Annu. Rev. Environ. Resour. 39, 327-362. https:// doi.org/10.1146/annurev-environ-031113-144051

Jackson, R.B., Vengosh, A., Darrah, T.H., Warner, N.R., Down, A., Poreda, R.J., Osborn, S.G., Zhao, K., Karr, J.D., 2013. Increased stray gas abundance in a subset of drinking water wells near Marcellus shale gas extraction. Proc. Natl. Acad. Sci. 110, 11250-11255. https://doi.org/10.1073/ pnas. 1221635110

Kelly, W.R., Matisoff, G., Fisher, J.B., 1985. The effects of a gas well blow out on groundwater chemistry. Environ. Geol. Water Sci. 7, 205-213. https://doi.org/10.1007/BF02509921

Llewellyn, G.T., Dorman, F., Westland, J.L., Yoxtheimer, D., Grieve, P., Sowers, T., Humston-Fulmer, E., Brantley, S.L., 2015. Evaluating a groundwater supply contamination incident attributed to Marcellus Shale gas development. Proc. Natl. Acad. Sci. 112, 6325-6330. https://doi.org/10.1073/ pnas.1420279112

Musat, F., 2015. The anaerobic degradation of gaseous, nonmethane alkanes - From in situ processes to microorganisms. Comput. Struct. Biotechnol. J. https://doi.org/10.1016/j.csbj.2015.03.002

Osborn, S.G., Vengosh, A., Warner, N.R., Jackson, R.B., 2011. Methane contamination of drinking water accompanying gas-well drilling and hydraulic fracturing. Proc. Natl. Acad. Sci. 108, E665-E666. https://doi.org/https://doi.org/10.1073/pnas.1100682108

Patterson, L.A., Konschnik, K.E., Wiseman, H., Fargione, J., Maloney, K.O., Kiesecker, J., Nicot, J.P., BaruchMordo, S., Entrekin, S., Trainor, A., Saiers, J.E., 2017. Unconventional Oil and Gas Spills: Risks, Mitigation Priorities, and State Reporting Requirements. Environ. Sci. Technol. 51, 2563-2573. https://doi.org/10.1021/acs.est.6b05749

Roy, N., Molson, J., Lemieux, J.M., Van Stempvoort, D., Nowamooz, A., 2016. Three-dimensional numerical simulations of methane gas migration from decommissioned hydrocarbon production wells into shallow aquifers. Water Resour. Res. 52, 5598-5618. https://doi.org/10.1002/2016WR018686

Sassen, R., Roberts, H.H., Carney, R., Milkov, A. V, DeFreitas, D.A., Lanoil, B., Zhang, C., 2004. Free hydrocarbon gas, gas hydrate, and authigenic minerals in chemosynthetic communities of the northern Gulf of Mexico continental slope: Relation to microbial processes. Chem. Geol. 205, 195-217. https://doi.org/10.1016/j.chemgeo.2003.12.032

Schroot, B.M., Klaver, G.T., Schüttenhelm, R.T.E., 2005. Surface and subsurface expressions of gas seepage to the seabed - Examples from the Southern North Sea. Mar. Pet. Geol. 22, 499-515. https://doi.org/10.1016/j.marpetgeo.2004.08.007 
Schwartz, M.O., 2015. Modelling the hypothetical methane-leakage in a shale-gas project and the impact on groundwater quality. Environ. Earth Sci. 73, 4619-4632. https://doi.org/10.1007/ s12665-014-3787-3

Segarra, K.E.A., Schubotz, F., Samarkin, V., Yoshinaga, M.Y., Hinrichs, K.-U., Joye, S.B., 2015. High rates of anaerobic methane oxidation in freshwater wetlands reduce potential atmospheric methane emissions. Nat. Commun. 6, 7477. https://doi.org/10.1038/ncomms8477

Stumm, W., Morgan, J.J., 1996. Chemical Equilibria and Rates in Natural Waters, Aquatic chemistry. Wiley. https://doi.org/10.1017/CBO9781107415324.004

Timmers, P.H., Suarez-Zuluaga, D.A., van Rossem, M., Diender, M., Stams, A.J., Plugge, C.M., 2016. Anaerobic oxidation of methane associated with sulfate reduction in a natural freshwater gas source. ISME J. 10, 1400-1412. https://doi.org/10.1038/ismej.2015.213

Tingay, M.R.P., Hillis, R.R., Morley, C.K., Swarbrick, R.E., Drake, S.J., 2005. Present-day stress orientation in Brunei: a snapshot of "prograding tectonics" in a Tertiary delta. J. Geol. Soc. London. 162, 39-49. https://doi.org/10.1144/0016-764904-017

Van Breukelen, B.M., Griffioen, J., Röling, W.F.M., Van Verseveld, H.W., 2004. Reactive transport modelling of biogeochemical processes and carbon isotope geochemistry inside a landfill leachate plume. J. Contam. Hydrol. 70, 249-269. https://doi.org/10.1016/j.jconhyd.2003.09.003

Van Stempvoort, D., Maathuis, H., Jaworski, E., Mayer, B., Rich, K., 2005. Oxidation of fugitive methane in ground water linked to bacterial sulfate reduction. Ground Water 43, 187-199. https://doi. org/10.1111/j.1745-6584.2005.0005.x

Vernes, R.W., van Doorn, T.H.., 2005. Van Gidslaag naar Hydrogeologische Eenheid; Toelichting op de totstandkoming van de dataset REGIS II. NITG-05-038-B. Utrecht:TNO.

Whiticar, M.J., 1999. Carbon and hydrogen isotope systematics of bacterial formation and oxidation of methane. Chem. Geol. 161, 291-314. https://doi.org/10.1016/s0009-2541(99)00092-3

Winngsplan Zuid-Oost Drenthe, 2003. . Assen: NAM. 


\section{APPENDIX}

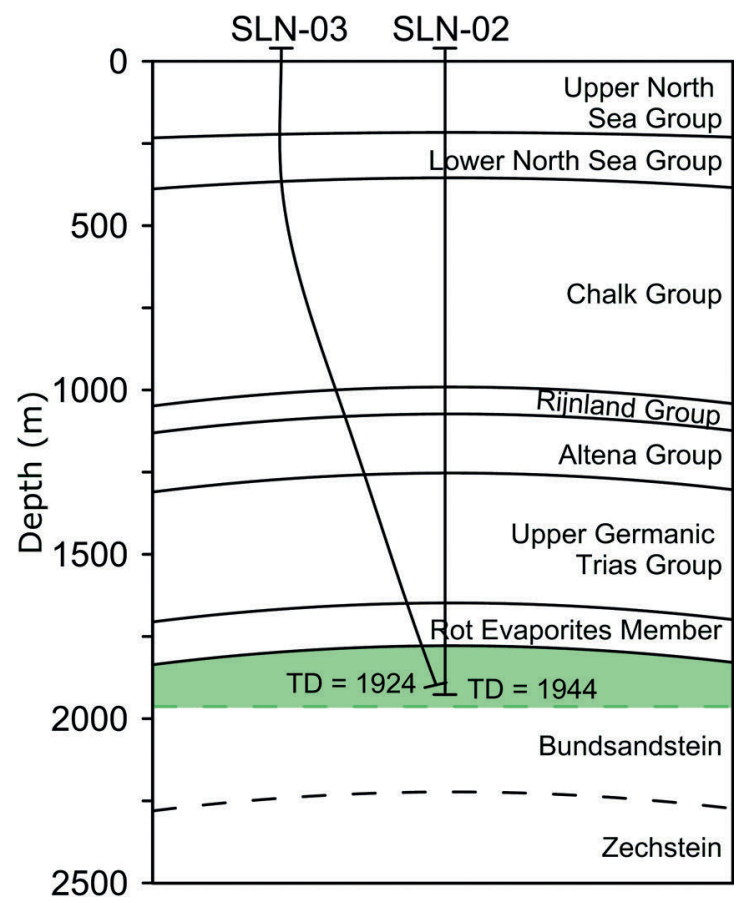

Figure S1 | Deep stratigraphy at the Sleen blowout site showing wells SLN-02 (blowout well) and SLN-03 (relief well) and their total depth (TD). Green dashed line and shaded area represent approximate location (prior to gas extraction) of the gas-water contact and the gas reservoir, respectively (Winngsplan Zuid-Oost Drenthe, 2003). 

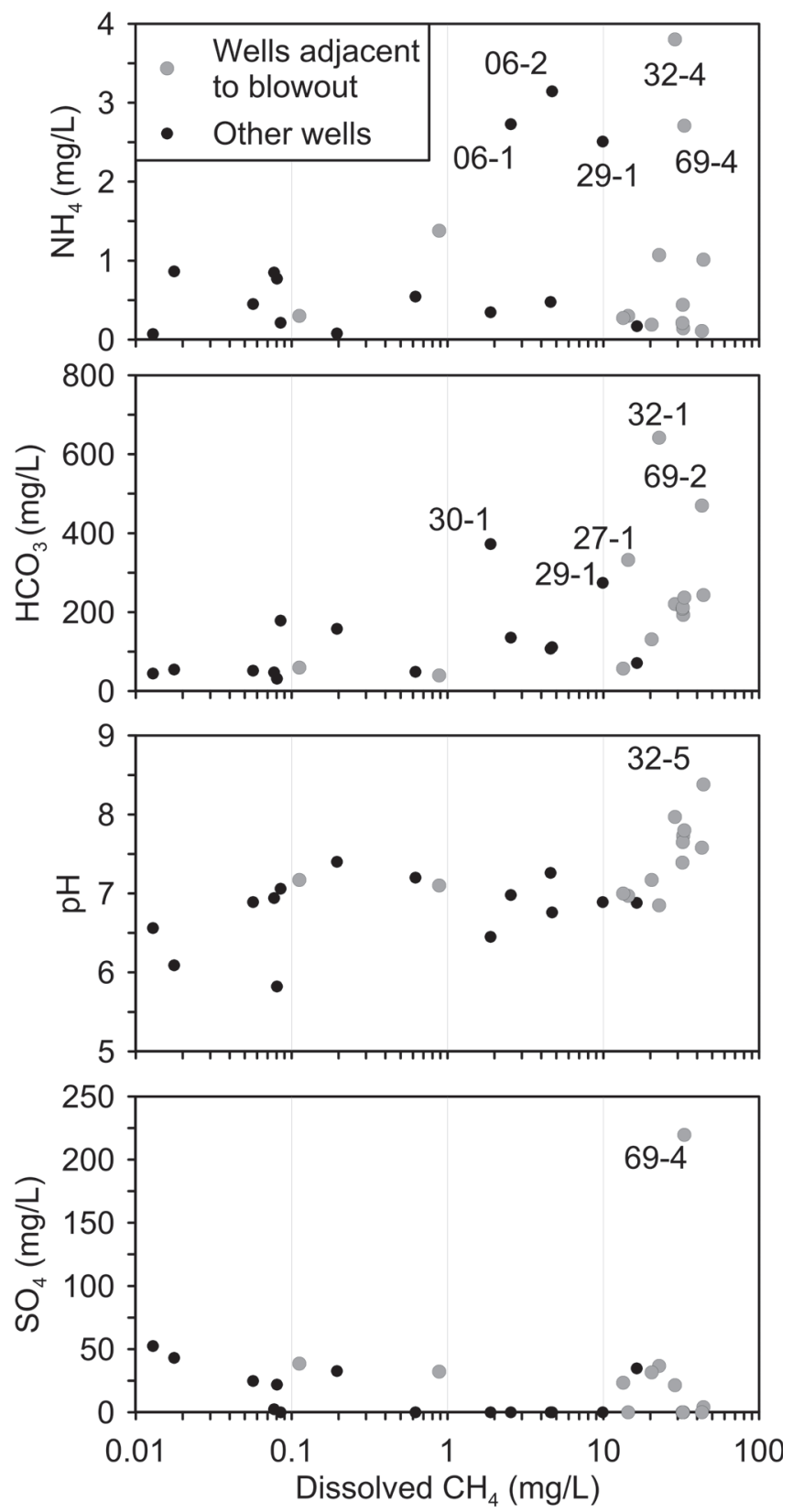

Figure S2 | Dissolved methane concentrations plotted against $\mathrm{pH}$ and concentrations of bicarbonate, ammonium and sulfate. 

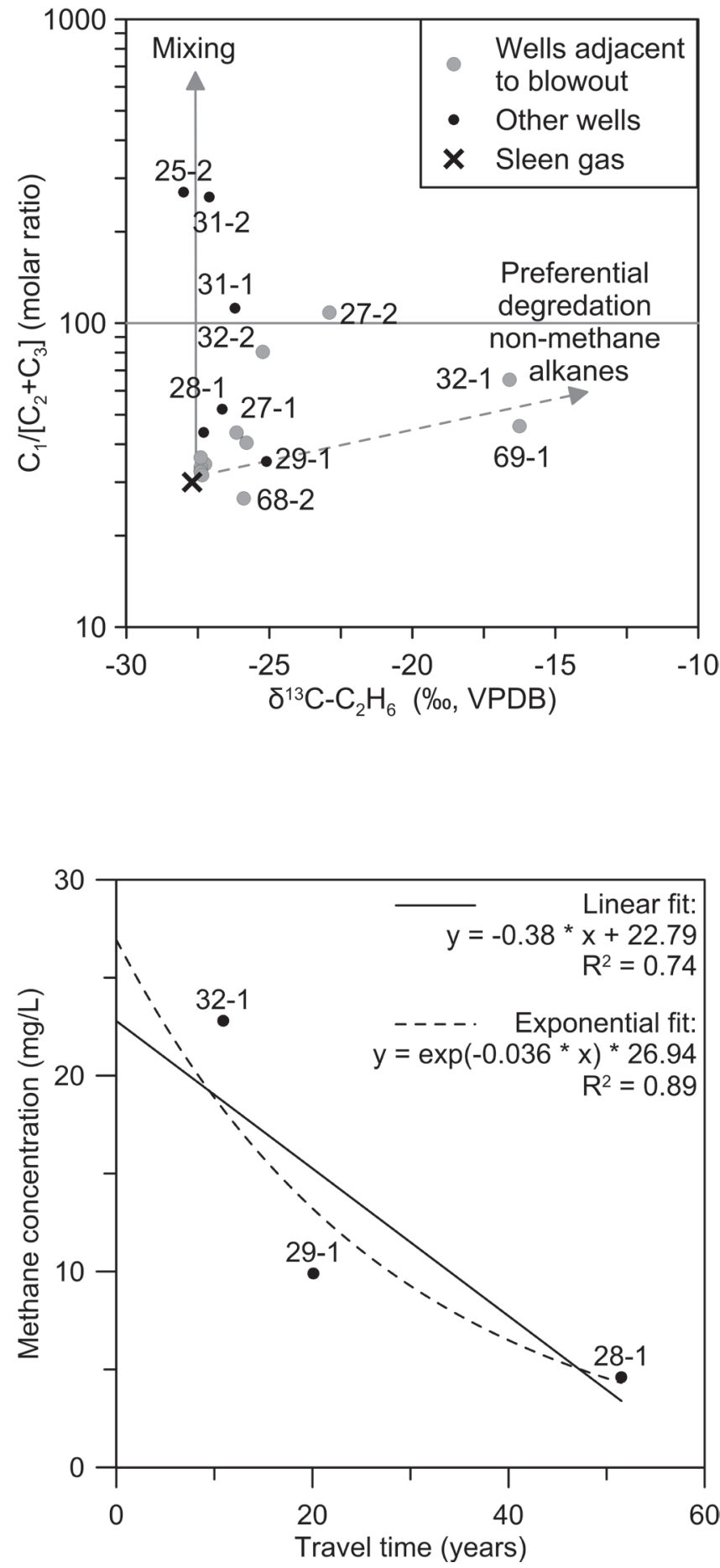

Figure S3 $\mid C_{1} /\left(C_{2}+C_{3}\right)$ vs. $\delta^{13} C-$ $\mathrm{C}_{2} \mathrm{H}_{6}$ of analyzed groundwater wells. Also shown are the $\delta^{13} \mathrm{C}-\mathrm{C}_{2} \mathrm{H}_{6}$ values of samples taken directly from the Sleen gas reservoir. Solid gray line shows the effect of mixing with biogenic methane and dashed gray line shows a hypothetical shift in $C_{1} /\left(C_{2}+C_{3}\right)$ and $\delta^{13} C-$ $\mathrm{C}_{2} \mathrm{H}_{6}$ hypothetical effect that preferential oxidation of nonmethane alkanes would have.

Figure S4 | Dissolved methane concentrations in the shallow Peelo formation along the transect from the blowout well (SLN-02) past wells 32, 29 and 28. Travel time is computed assuming an effective groundwater velocity of $10 \mathrm{~m} / \mathrm{yr}$. $\mathrm{R}^{2}$ values representing both zero and first order decay are given with first order decay giving a more accurate fit. A linear methane oxidation rate of $0.38 \mathrm{mg} / \mathrm{L} / \mathrm{yr}$ and a half-life of $\operatorname{LN}(2) / 0.036=19.25$ years are obtained. 
Table S1 | Chemical and isotopic composition of gas samples from the Sleen gas field.

\begin{tabular}{lccccccccc}
\hline $\begin{array}{l}\text { Well } \\
\text { name }\end{array}$ & Analysis date & $\begin{array}{c}\mathrm{C}_{1} \\
(\%)\end{array}$ & $\begin{array}{c}\mathrm{C}_{2} \\
(\%)\end{array}$ & $\begin{array}{c}\mathrm{C}_{3} \\
(\%)\end{array}$ & $\begin{array}{c}\mathrm{CO}_{2} \\
(\%)\end{array}$ & $\begin{array}{c}\mathrm{N} 2 \\
(\%)\end{array}$ & $\begin{array}{c}\mathrm{C}_{1} / \\
\left(\mathrm{C}_{2}+\mathrm{C}_{3}\right)\end{array}$ & $\begin{array}{c}\delta^{13} \mathrm{C}_{-} \mathrm{CH}_{4} \\
(\% \circ, \mathrm{VPDB})\end{array}$ & $\begin{array}{c}\delta^{13} \mathrm{C}-\mathrm{C}_{2} \mathrm{H}_{6} \\
(\% \circ, \mathrm{VPDB})\end{array}$ \\
\hline SLN-04 & $06 / 20 / 2004$ & 45.5 & 1.0 & 0.0 & 0.0 & 53.0 & 45.7 & -22.1 & -27.7 \\
\hline SLN-05 & $11 / 11 / 2002$ & 46.6 & 1.0 & 0.0 & 0.1 & 52.1 & 46.3 & -22.0 & -27.7 \\
\hline SLN-07 & $11 / 11 / 2002$ & 45.8 & 1.0 & 0.0 & 0.1 & 53.1 & 45.5 & -22.2 & -27.8 \\
\hline
\end{tabular}

Table S2 | Comparison of replicate measurements (indicated with a star(*)) carried out in wells 32-3 and 69-1.

\begin{tabular}{lccccc} 
Screen ID & Sampling Date & $\mathrm{CH}_{4}(\mathrm{mg} / \mathrm{L})$ & $\mathrm{C} 1 /[\mathrm{C} 2+\mathrm{C} 3]$ (molar ratio) & $\delta^{13} \mathrm{C}_{-} \mathrm{CH}_{4}(\% \circ, \mathrm{PDB})$ & $\delta \mathrm{D}-\mathrm{CH}_{4}(\% \circ, \mathrm{SMOW})$ \\
\hline $32-3$ & $13 / 04 / 16$ & 32.6 & 34.4 & -21.3 & -117 \\
\hline $32-3^{*}$ & $28 / 06 / 16$ & 29.0 & 31.0 & -21.0 & -116 \\
\hline $69-1$ & $14 / 04 / 16$ & 20.4 & 46.5 & -17.7 & -75 \\
\hline $69-1^{*}$ & $28 / 06 / 16$ & 19.5 & 49.7 & -19.1 & -78
\end{tabular}



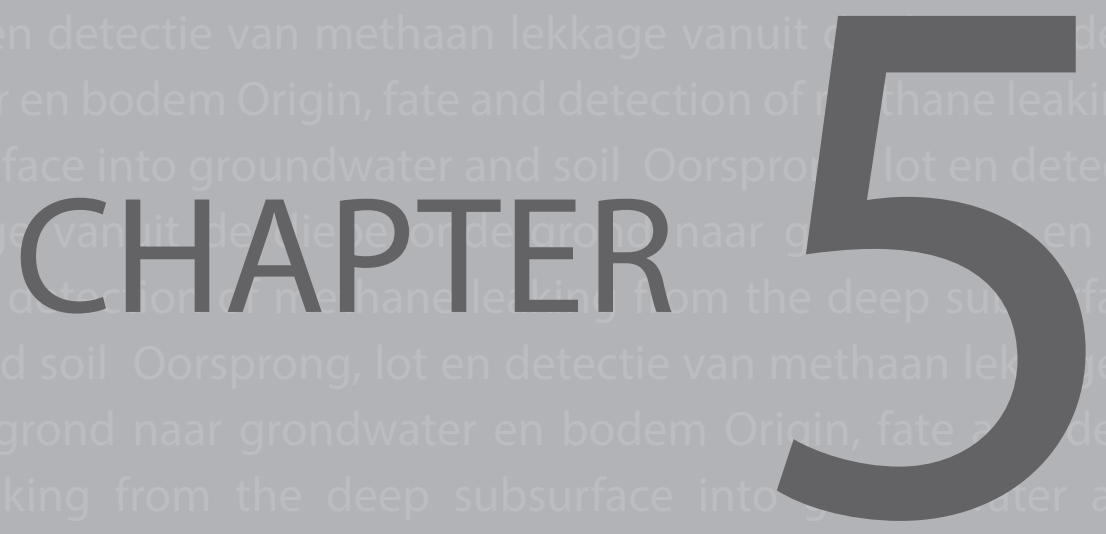

\section{Impact of groundwater flow on methane gas migration and retention in unconsolidated aquifers}

Gilian Schout

Niels Hartog

S. Majid Hassanizadeh

Rainer Helmig Jasper Griffioen 


\section{ABSTRACT}

Methane leaking at depth from hydrocarbon wells poses an environmental and safety hazard. However, determining the occurrence and magnitude of gas migration at ground surface is challenging, as part of the leaking gas is retained during upward migration. We investigated migration through unconsolidated sedimentary aquifers using a two-phase, two-component (water and methane) flow and transport model constructed in DuMux. A sensitivity analysis for migration through a $60 \mathrm{~m}$ thick sandy aquifer showed that retention by dissolution can be significant even with low groundwater Darcy velocities of $1 \mathrm{~m} . \mathrm{yr}^{-1}$. Retention was negligible in the absence of groundwater flow. Besides groundwater velocity, both hydrogeological (permeability, entry pressure, pore-size distribution, and residual gas saturation) and leakage conditions (depth, magnitude and spatial dimensions) determined model outcomes. Additional simulations with interbedded finer grained sediments resulted in substantial lateral spreading of migrating gas. This delayed upward migration and enhanced retention in overlying sandy units where groundwater velocities are highest. Overall, the results of this study show that for unconsolidated aquifer systems and the most commonly observed leakage rates $\left(0.1-10 \mathrm{~m}^{3} \cdot \mathrm{d}^{-1}\right)$, significant amounts of migrating methane can be retained due to dissolution into laterally flowing groundwater. Consequently, resulting atmospheric methane emissions above such leaks may be delayed with decades after the onset of leakage, significantly reduced, or prevented entirely. 


\section{1 | INTRODUCTION}

The reliance on fossil fuel resources for the majority of the world's energy supply has resulted in a large number of onshore hydrocarbon wells, conservatively estimated at over 4 million (Davies et al., 2014). In spite of efforts to maintain the vertically isolating function of geological formations that are penetrated when installing and operating such wells, failure of the wellbore system is a commonly observed problem (Davies et al., 2014) and can lead to leakage of hazardous liquids and gases. Furthermore, research has shown that this risk continues or may develop even after the active life-time of wells and their abandonment (Kang et al., 2014; Townsend-Small et al., 2016). Particularly, upward leakage of methane through anthropogenically opened, unintended connections between hydrocarbon reservoirs and the shallow subsurface has become a growing concern worldwide as it may contribute to greenhouse gas emissions (Kang et al., 2014), deteriorate water quality (Vengosh et al., 2014), and form an explosion hazard (Chilingar \& Endres, 2005). On top of that, leaky wells could serve as pathways for the migration of other fluids when the downhole conditions are actively changed, for example when hydraulic fracturing is carried out (Brownlow et al. 2016) or $\mathrm{CO}_{2}$ is stored (Gasda et al., 2004) in nearby wells. Thus, their presence may also hamper the safe implementation of future uses of the subsurface.

To be able to quantify and mitigate these risks, the accurate detection of gas leakage is vital. This is typically achieved by measurements of either sustained casing pressure (SCP) or surface casing vent flow (SCVF) at the wellhead (King \& King, 2013). However, these measurements may only reflect a part of the total leakage flux, as a significant fraction of leaking gas can escape the wellbore system entirely and enter the surrounding geology (Forde et al., 2019), which is also referred to as gas migration. Lackey and Rajaram (2018) identified three main mechanisms that may lead to gas migration: (1) gas circumvention, when gas migrates through a cemented outer annulus and a section of low quality cement is overlain by a section of higher quality cement, causing the gas to migrate outwards, (2) groundwater crossflow, when gas leaks through an uncemented outer annulus and is transported into the surrounding formation by lateral groundwater flow, and (3) SCP-induced gas migration, when the gas pressure at the bottom of the surface casing exceeds the hydrostatic pressure leading to gas 'overflow'.

As gas migrating outside the wellbore may become trapped, dissolved or degraded (Cahill et al., 2018), surficial or shallow groundwater wells may only detect leakage after long periods of time, or possibly never. Measurements of soil gas migration are typically carried out using surface flux chambers (Erno \& Schmitz, 1996). In the vadose zone, oxidation and dispersion of methane has indeed been shown to be capable of masking leaking wells from being detected at the surface entirely (McMahon et al., 2018; Schout et al., 2019). Furthermore, a recent field experiment where methane was released in a shallow aquifer showed that the combined effects of trapping and dissolution of leaking gas in the saturated zone significantly reduced the amount of gas that reached the surface (Cahill et al., 2018). Lastly, several field-based studies have shown that anaerobic methane oxidation coupled to either 
sulphate reduction (Van Stempvoort et al., 2005; Wolfe \& Wilkin, 2017) and/or reduction of iron and manganese oxides (Schout et al., 2018; Woda et al., 2018) can lead to attenuation of a migrating methane plume. With increasing depth and longer migrating pathways leaking gas can become more severely affected by these attenuation and retention processes, and in turn surficial or shallow subsurface measurements become increasingly less reliable tools for detecting gas migration. Indeed, the fate of methane from leaks occurring at depths greater than $10 \mathrm{~m}$ was identified as a key knowledge gap in studying gas migration (Cahill et al., 2019).

Given the complexity and related costs of measuring gas leakage in field or experimental settings, methane migration has also been assessed by means of multiphase numerical flow and transport simulations. Several studies have aimed to determine ranges of possible gas migration flow rates from the reservoir depth to shallow aquifers through high permeability pathways, such as faults or improperly cemented annuli (Kissinger et al., 2013; Nowamooz et al., 2015; Reagan et al., 2015; Schwartz, 2015). Tatomir et al. (2018) simulated migration of methane at great depth ( 1500 m) into an inclined, regional aquifer. Breakthrough times of gaseous methane at various offset distances from the leak origin were calculated, that could for example correspond to conductive faults connecting the deep aquifer with an overlying freshwater aquifer. Rice et al. (2018) investigated SCP-induced gas migration through a shale formation present at the bottom end of the surface casing into an overlying shallow aquifer. They showed that for given source zone pressures, the permeability distribution and the parametrization of the capillary pressure saturation and relative permeability functions of the shale formation controlled the flow rate of methane into the overlying aquifer. Depending on these properties, flow rates at the base of the aquifer can be slow, which may allow methane contamination to go undetected.

Other studies assumed leakage to a shallow aquifer system occurred, and focused on the migration and attenuation of methane therein. Roy et al. (2016) coupled their multiphase model to a reactive transport simulator and showed that in confined aquifers, anaerobic methane oxidation coupled to sulphate reduction could attenuate a migrating dissolved methane plume significantly. This attenuating effect was even larger in unconfined aquifers, where aerobic methane oxidation was also possible. Moortgat et al. (2018) simulated gas phase methane migration through an aquifer system characterized by the presence of highly permeable pathways such as fractures and fluvial channels. They showed that rapid lateral gas migration over distances of several kilometers is possible through these features, but that migration is much less rapid in unfractured media. D'Aniello (2019) simulated leakage of methane from a geothermal well into a 2 meter thick surficial unconsolidated aquifer. Given the limited thickness and because mass transfer of methane to the aqueous phase was ignored, retention of methane in this aquifer was limited. Klazinga et al. (2019) carried out 2D simulations imitating the field experiments by Cahill et al. (2017) where methane gas was injected up to $10 \mathrm{~m}$ depth in a sandy aquifer. Lateral migration of the gas phase was shown to be significant even over such a relatively shallow interval, as a result of anisotropic sediments, and the presence of low permeability layers. Furthermore, wider plumes and 
larger groundwater flow velocities resulted in larger amounts of methane that were retained in the aquifer.

The effect of methane retention by dissolution into laterally flowing groundwater has not been considered in detail in previous studies of gas migration. In spite of the relatively low solubility of methane, dissolutive retention could be important in the shallow part of unconsolidated groundwater systems, where groundwater velocities are generally higher. Methane migration through unconsolidated aquifers is also less likely to be dominated by quick gas phase flow through preferential flow paths, which reduces the potential for dissolutive retention. Other factors also possibly play a role, such as the increase in methane aqueous solubility with increasing hydrostatic pressure (i.e. depth) and the lateral spreading of the methane plume as a result of anisotropy and low permeable layers. The interaction of these transport processes and their influences on gas migration were studied in a parameter sensitivity analysis based on 3D, two-phase, two-component numerical simulations across a range of realistic conditions. The impacts of horizontally layered unconsolidated aquifer systems on methane migration and retention were illustrated by simulation of a number of additional scenarios, based on the geology encountered at two recently identified leaking wellbore sites in the Netherlands. The overall aim of this study was to determine whether, and if so, to what extent subsurface methane migration through laterally flowing groundwater is impacted by methane dissolution.

\section{$5.2 \mid$ MATERIAL AND METHODS}

\subsubsection{Governing equations and constitutive relations}

Numerical modelling was carried out using the open source multiphysics simulation package DuMu$^{\times}$(Ackermann et al., 2017; Flemisch et al., 2011). DuMu is capable of calculating multiphase multicomponent flow and transport at the continuum scale (also referred to as miscible two-phase flow or compositional flow). For this study, two phases a (liquid and gas) and two components $k\left(\mathrm{H}_{2} \mathrm{O}\right.$ and $\left.\mathrm{CH}_{4}\right)$ were considered. The model accounts for mass transfer between the two phases as well as the compressibility of both phases. Phase velocities are calculated using Darcy's law. Furthermore, binary diffusion is assumed, and the diffusive fluxes in each phase are calculated according to Fick's law. The fully coupled mass balance equation is then formulated as follows:

$$
\sum_{\alpha} \frac{\phi \partial\left(\rho_{\alpha} X_{\alpha}^{k} S_{\alpha}\right)}{\partial t}=\nabla \cdot \sum_{\alpha}\left\{\rho_{\alpha} X_{\alpha}^{k} \frac{\boldsymbol{\kappa} k_{r \alpha}}{\mu_{\alpha}}\left(\nabla P_{\alpha}-\rho_{\alpha} \boldsymbol{g}\right)\right\}+\nabla \cdot \sum_{\alpha}\left\{\rho_{\alpha} D_{e f f, \alpha} \nabla X_{\alpha}^{k}\right\}+q^{k}
$$

where $\phi$ is the porosity, $\rho$ is the density, $X$ is the mass fraction, $S$ is the saturation, $\boldsymbol{K}$ is the intrinsic permeability tensor, $k_{r}$ is the relative permeability, $\mu$ is the dynamic viscosity, $P$ is the pressure, $\boldsymbol{g}$ is the gravity vector, $D_{\text {eff }}$ is the effective diffusion coefficient and $q$ is a source or sink term. A number of constitutive relationships are needed to close this system of equations. 
Firstly, the sum of the saturations and that of the mass fractions of the two components in each phase must equal 1:

$$
S_{g}+S_{l}=1, \quad \sum_{k} X_{g}^{k}=1, \quad \sum_{k} X_{l}^{k}=1
$$

where the subscripts $g$ and $w$ represent the gaseous and liquid phase, respectively. The phase pressures are related by the capillary pressure $P_{c}$ as given by:

$$
P_{g}-P_{l}=P_{c}\left(S_{g}\right)
$$

The formulations by Brooks and Corey (1964) were used for the capillary pressure - saturation relationship and relative permeabilities:

$$
\begin{gathered}
P_{c}\left(S_{g}\right)=P_{e} S_{e}^{-\frac{1}{\lambda}} \\
k_{r l}=S_{e}^{2 / \lambda+3}, \quad k_{r g}=\left(1-S_{e}\right)^{2}\left(1-S_{e}^{\frac{2}{\lambda}+1}\right)
\end{gathered}
$$

where $P_{e}$ is the capillary entry pressure, $S_{e}$ is the effective saturation and $\lambda$ is the pore size distribution index. $S_{e}$ is defined as:

$$
S_{e}=\frac{S_{l}-S_{l r}}{1-S_{g r}-S_{l r}}
$$

where $S_{l r}$ and $S_{g r}$ are the residual (or 'irreducible') liquid and gaseous saturation, respectively. According to these formulations, the relative permeability of the gas phase is 0 as long as $S_{g}<S_{g r}$. Hence, the residual saturations in each cell have to reach at least up to the (threshold) residual gas saturation before a neighboring cell can be invaded by the gas phase (Figure S1). A regularization of the Brooks-Corey $P_{c}\left(S_{g}\right)$ relationship was used for $S_{e}>1$ and $S_{e}<0.01$. To avoid numerical issues with having an infinite gradient of the $P_{c}\left(S_{g}\right)$ curve, the slope of the curve when approaching these limits was extended up to $S_{l}=1$ and $S_{l}=0$, respectively (Figure S1).

Both water and methane components can be present in either phase. Concentrations in each phase are assumed to be at thermodynamic equilibrium, meaning that mass transfer between the two phases occurs instantaneously at every time step in each control volume. Methane solubility is determined according to Henry's law and is temperature and pressure dependent, with the Henry's coefficient based on the IAPWS formulations (Fernández-Prini et al., 2003). A freshwater aquifer is assumed and therefore the effects of variable salinities on methane solubility are not considered. The solubility of methane also determines the phase state of the model, with a gas phase appearing once the mole fraction of methane $\left(x_{1}^{\mathrm{CH}}\right)$ exceeds that of the equilibrium (solubility) mole fraction, and vice versa. Phase appearance and disappearance are accompanied by a primary variable switch: from $P_{1}$ and $S_{g}$ when both phases are present to $P_{1}$ and $x_{l}^{\mathrm{CH} 4}$ when only the liquid phase is present. Energy transport is not simulated, and the model is considered to be in thermal equilibrium. For the spatial 
discretization a vertex centered finite volume method ('box method') is used and a fully implicit, backward Euler method for the temporal discretization (Helmig, 1997).

The density of the gaseous phase follows the ideal gas law. Viscosity is calculated as described in Reid et al. (1987). In the range of temperature and pressure relevant for this study, the density and viscosity of methane gas calculated in this manner were shown to be nearly equal to more complex equations of state (Kissinger et al., 2013). The density and viscosity of the liquid phase are both pressure and temperature dependent, according to the IAPWS definitions (Wagner \& Pruss, 2002). The influence of the phase composition on the liquid phase properties is not taken into account, since even at the greatest depth considered in this study (480 m of water column) the maximum $\mathrm{CH}_{4}$ mass concentration is negligible compared to the aqueous phase density ( $0.1 \%)$. The diffusion coefficient of water in the gaseous phase is determined according to the method in Fuller et al. (1966) and the diffusion coefficient of methane in the aqueous phase according to Reid et al. (1987). Mechanical dispersion was not implemented in the model. In multiphase systems, the dispersion coefficient is saturation dependent, which would result in a much more complex system of equations (Helmig, 1997) and excessive runtimes. Computations were performed on a workstation and parallelized over 16 processors, resulting in runtimes of up to 2 days for the sensitivity analysis and 4 days for the layered scenarios.

\subsection{2 | Geological context and conceptual model}

The range of hydrogeological conditions for which gas migration was studied are representative for unconsolidated sedimentary groundwater systems globally, but were inspired by the conditions that prevail in the subsurface of the Netherlands. The Netherlands is one of the major oil and gas producing nations in Europe with around 2500 onshore oil and gas wells (Schout et al., 2019). A survey of 986 gas wells by the State Supervision of Mines (SodM) revealed some form of well barrier failure at 227 (23\%) of these wells (SodM, 2019). Observations of gas bubbles in flooded well cellars showed that leakage of thermogenic gas occurred at at least 13 wells (1.3\%). Hydrogeologically, the country is characterized by the presence of shallow sandy aquifer units of Plio-Pleistocene age. These aquifers can be either phreatic or, in the northern and western part of the country, can be confined by overlying Holocene deposits (Figure S2). A succession of thick, marine clays of Neogene and Paleogene age form the bedrock below the aquifer units in nearly the entire country (de Vries, 2007). Typically, the surface casing of oil and gas wells would at least extend down into these clays, the depths of which can be up to around $500 \mathrm{~m}$ below surface in the oil and gas producing areas. The modelled domain is a hypothetical rectangular block of a sandy aquifer within such a unconsolidated sedimentary sequence (Figure 1a). Gas migration into the base of the model is assumed. Conceptually, it could be caused by a number of possible failure scenarios occurring below the simulated part of the aquifer, including SCP-induced gas migration or gas circumvention. 


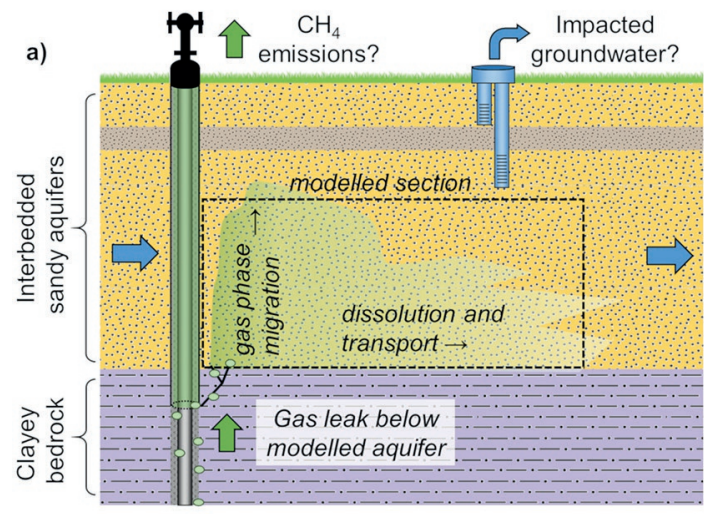

b)

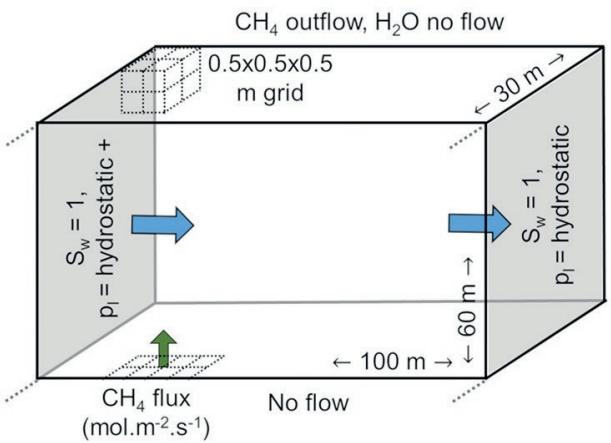

Figure 1 | Conceptual model example (a) and numerical implementation of the modelled section (b).

\subsubsection{Domain discretization, boundary and initial conditions}

The dimensions of the simulated aquifer were set to 100x60x60 m (XYZ), sufficiently large so that no boundary effects on gas migration occurred. Owing to symmetry in the $y$-axis, only half of this domain is simulated. Initial numerical testing showed that model outcomes stabilized when using a grid size smaller than $1 \times 1 \times 1 \mathrm{~m}$. Hence, a grid size of $0.5 \times 0.5 \times 0.5 \mathrm{~m}$ was used, resulting in a total of 1,440,000 cells. The simulation time is 20 years, during which injection of $\mathrm{CH}_{4}$ is continuous. For the $\mathrm{CH}_{4}$ flux at the inlet $\left(\mathrm{mol} \cdot \mathrm{m}^{-2} \cdot \mathrm{s}^{-1}\right)$ a Neumann type boundary was used over 8 cells from $\mathrm{x}=40$ to $42 \mathrm{~m}\left(2 \times 1 \mathrm{~m}^{2}\right)$, or what would be $2 \times 2 \mathrm{~m}^{2}$ area when accounting for the half of the domain that is not modelled (Figure $1 \mathrm{~b}$ ). The remainder of the bottom face of the model and the two lateral faces parallel to the direction of groundwater flow are treated as no-flow boundaries for both components. The two lateral faces perpendicular to groundwater flow are assigned Dirichlet conditions with a pressure equal to the hydrostatic pressure, albeit with a minor increase in pressure on one side to induce groundwater flow. Lastly, the top face of the model is assigned a no-flow condition for $\mathrm{H}_{2} \mathrm{O}$ and an outflow condition for $\mathrm{CH}_{4}$. This allows methane to escape the model freely through the top boundary but keeps water flowing strictly horizontally. Conceptually, this corresponds to cases where the gas either escapes to the atmosphere or continues to migrate upwards to overlying layers, depending on the depth of the top of the domain. The model is initially fully water saturated $\left(\mathrm{S}_{\mathrm{g}}=0\right)$ and no dissolved methane is present anywhere. A thermal gradient of $31.3^{\circ} \mathrm{C} . \mathrm{km}^{-1}$ is imposed in all simulations, equivalent to the average thermal gradient found in the Netherlands (Verweij et al., 2018), on top of the yearly average ambient air temperature of $10^{\circ} \mathrm{C}$. The density and viscosity of water inside the model and at its lateral boundaries are determined during an initialization phase that precedes the actual model run. 


\subsection{4 | Parameter space sensitivity analysis}

A total of 17 simulations were run, together encompassing a parameter space representative of the expected conditions for gas migration through unconsolidated sandy aquifers (Table 1). Groundwater flow velocities up to $100 \mathrm{~m} . \mathrm{yr}^{-1}$ were considered, as observed for regional groundwater flow in the Netherlands (Bloemendal \& Hartog, 2018). The thickness of the model is $60 \mathrm{~m}$. For the base case a depth of $60 \mathrm{~m}$ was chosen for the bottom of the model domain, with depths of 240 and $480 \mathrm{~m}$ also considered. Preliminary simulations showed that model outcomes are insensitive to the temperature gradient however, as simulations ran with a constant temperature of $10^{\circ} \mathrm{C}$ yielded virtually equal outcomes. Hence, variations in the geothermal gradient were not considered.

Methane flow rates at the inlet were varied between 0.1 and $10 \mathrm{~m}^{3} \mathrm{CH}_{4}^{\text {atm }} \cdot \mathrm{d}^{-1}$ (i.e. the volumetric $\mathrm{CH}_{4}$ flow rate at atmospheric pressure and $10^{\circ} \mathrm{C}$ ) as the majority of reported SCVF rates fall within this range. For example, $68 \%$ of wells with SCVF in British Columbia, Canada, had flow rates below $1 \mathrm{~m}^{3} \cdot \mathrm{d}^{-1}$ and $25 \%$ between 1 and $10 \mathrm{~m}^{3} . \mathrm{d}$ (Wisen et al., 2019). Similarly, the vast majority of reported SCVF rates in Alberta, Canada, are also below $10 \mathrm{~m}^{3} . \mathrm{d}^{-1}$ (Dusseault et al., 2014). It should be noted that very large SCVF rates exceeding $1000 \mathrm{~m}^{3} . \mathrm{d}^{-1}$ have also been reported (e.g. Nowamooz et al., 2015), but were not considered in this study. Imposed leakage rates were sustained for the full 20 year simulation period. The assumption of a constant leakage rate over long time periods was also made by Rice et al, 2018. Field measurements of leakage from abandoned wells in Pennsylvania that remained virtually constant over a 3 year time period support this assumption (Kang et al., 2016), as do measured SCPs that sustained over measurements periods up to nearly 10 years (Lackey et al., 2018).

While properties of sandy aquifers are well known for single-phase problems, experimental studies where multiphase properties are determined are sparse. To reduce the number of possible scenarios, three sets of experimentally determined values for an air-water system were used for the porosity, permeability, entry pressure, and pore size distribution (Clayton, 1999). As a base case assumption, the properties of a coarse grained fluvial sand (D50 of $0.61 \mathrm{~mm}$ ) were taken (Table 1). The effect of migration through finer grained sands was considered by implementing the values determined for a 'hydraulic fill' (D50 of $0.16 \mathrm{~mm}$ ) and a 'clayey alluvium' (D50 of $0.09 \mathrm{~mm}$ ). Hereafter, we refer to these as a fine sand and very fine sand, respectively, according to the Wentworth scale of grain size classifications (Wentworth, 1922). Given that the transverse permeability is not known, an anisotropy factor $\left(\mathrm{k}_{\mathrm{h}} / \mathrm{k}_{\mathrm{v}}\right)$ of 5 was assumed in all simulations. Variations in anisotropy with a $k_{h} / k_{v}$ of 1 and 10 were simulated in scenarios 14 and 15 , respectively (Table 1 ). A residual gas saturation of $1 \%$ was assumed. The sensitivity of model outcomes to the residual gas saturation was investigated in scenarios 12 and 13 , with values of $0 \%$ and $15 \%$, respectively. The residual wetting phase saturation was set to $10 \%$ for all simulations. In scenarios 16 and 17 the inlet boundary size was changed to $1 \times 1 \mathrm{~m}^{2}$ and $4 \times 4 \mathrm{~m}^{2}$, while maintaining the total gas flow rate over the boundary. 
Table 1 | Summary of relevant input parameters used for the 17 simulated scenarios in the sensitivity analysis. Bold numbers indicate parameters that are varied with respect to the base case scenario.

\begin{tabular}{|c|c|c|c|c|c|c|c|c|c|c|}
\hline $\begin{array}{l}\text { Scenario } \\
\text { [\#] }\end{array}$ & $\begin{array}{c}{ }^{*} Q_{g}{ }^{\text {in }} \\
{\left[\mathrm{m}^{3} \cdot \mathrm{d}^{-1}\right]}\end{array}$ & $\begin{array}{c}q_{w} \\
{\left[m \cdot y r^{-1}\right]}\end{array}$ & $\begin{array}{c}\text { Depth } \\
\text { [m] }\end{array}$ & Porosity [-] & $\begin{array}{c}k_{h} \\
{\left[m^{2}\right]}\end{array}$ & $\begin{array}{c}k_{v} \\
{\left[m^{2}\right]}\end{array}$ & $\begin{array}{c}\mathrm{P}_{\mathrm{e}} \\
{[\mathrm{Pa}]}\end{array}$ & $\begin{array}{c}\lambda \\
{\left[\mathrm{m}^{-1}\right]}\end{array}$ & $\begin{array}{l}\mathrm{S}_{\mathrm{gr}} \\
{[-]}\end{array}$ & Note \\
\hline 1 & 0.1 & 1 & 60 & 0.38 & $5.3 \mathrm{E}-11$ & $1.1 \mathrm{E}-11$ & 1766 & 1.50 & 0.01 & 'base case' \\
\hline 2 & 0.1 & 0 & 60 & 0.38 & $5.3 \mathrm{E}-11$ & $1.1 \mathrm{E}-11$ & 1766 & 1.50 & 0.01 & \\
\hline $3 * *$ & 0.1 & 0 & 60 & 0.38 & $5.3 \mathrm{E}-11$ & $1.1 \mathrm{E}-11$ & 1766 & 1.50 & 0.01 & $\mathrm{x}_{\mathrm{i}}^{\mathrm{CH} 4} / \mathrm{x}_{\max }{ }^{\mathrm{CH} 4}=95 \%$ \\
\hline 4 & 1 & 1 & 60 & 0.38 & $5.3 \mathrm{E}-11$ & $1.1 \mathrm{E}-11$ & 1766 & 1.50 & 0.01 & \\
\hline 5 & 0.1 & 1 & 60 & 0.45 & $7.8 \mathrm{E}-12$ & $1.6 \mathrm{E}-12$ & 3924 & 1.20 & 0.01 & Fine sand \\
\hline 6 & 0.1 & 1 & 60 & 0.33 & 2.7E-11 & $5.4 \mathrm{E}-12$ & 2256 & 0.15 & 0.01 & Very fine sand \\
\hline 7 & 1 & 10 & 60 & 0.38 & $5.3 \mathrm{E}-11$ & $1.1 \mathrm{E}-11$ & 1766 & 1.50 & 0.01 & \\
\hline 8 & 1 & 100 & 60 & 0.38 & $5.3 \mathrm{E}-11$ & $1.1 \mathrm{E}-11$ & 1766 & 1.50 & 0.01 & \\
\hline 9 & 10 & 100 & 60 & 0.38 & $5.3 \mathrm{E}-11$ & $1.1 \mathrm{E}-11$ & 1766 & 1.50 & 0.01 & \\
\hline 10 & 1 & 1 & 240 & 0.38 & $5.3 \mathrm{E}-11$ & $1.1 \mathrm{E}-11$ & 1766 & 1.50 & 0.01 & \\
\hline 11 & 1 & 1 & 480 & 0.38 & $5.3 \mathrm{E}-11$ & $1.1 \mathrm{E}-11$ & 1766 & 1.50 & 0.01 & \\
\hline 12 & 0.1 & 1 & 60 & 0.38 & 5.3E-11 & $1.1 \mathrm{E}-11$ & 1766 & 1.50 & 0.00 & \\
\hline 13 & 0.1 & 1 & 60 & 0.38 & $5.3 \mathrm{E}-11$ & $1.1 \mathrm{E}-11$ & 1766 & 1.50 & 0.15 & \\
\hline 14 & 0.1 & 1 & 60 & 0.38 & $5.3 \mathrm{E}-11$ & $5.3 \mathrm{E}-11$ & 1766 & 1.50 & 0.01 & $\mathrm{k}_{\mathrm{h}} / \mathrm{k}_{\mathrm{v}}=1$ \\
\hline 15 & 0.1 & 1 & 60 & 0.38 & $5.3 \mathrm{E}-11$ & $5.3 \mathrm{E}-12$ & 1766 & 1.50 & 0.01 & $\mathrm{k}_{\mathrm{h}} / \mathrm{k}_{\mathrm{v}}=10$ \\
\hline 16 & 0.1 & 1 & 60 & 0.38 & $5.3 \mathrm{E}-11$ & $1.1 \mathrm{E}-11$ & 1766 & 1.50 & 0.01 & Area inlet: $1 \times 1 \mathrm{~m}^{2}$ \\
\hline 17 & 0.1 & 1 & 60 & 0.38 & $5.3 \mathrm{E}-11$ & $1.1 \mathrm{E}-11$ & 1766 & 1.50 & 0.01 & Area inlet: $4 \times 4 \mathrm{~m}^{2}$ \\
\hline
\end{tabular}

*Volumetric $\mathrm{CH}_{4}$ flow rate over inlet at atmospheric pressure and $10^{\circ} \mathrm{C}$ - due to domain symmetry only half of this flow rate is applied in the model. ${ }^{* *}$ Initial methane concentration at $95 \%$ of the depth-dependent solubility mole fraction $\left(x_{i}{ }^{\mathrm{CH} 4} / \mathrm{x}_{\max }{ }^{\mathrm{CH} 4}=95 \%\right)$.

\subsubsection{Setup of two layered case studies based on real sites}

For the sensitivity analysis, a simplified, homogeneous, sandy aquifer was considered. However, in unconsolidated sedimentary basins these aquifers are typically alternated by layers of both coarser and finer grained sediments, ranging from gravel to clay. To investigate the effect of such stratification on gas migration, additional simulations were carried out based on the hydrogeology observed at two locations where methane leakage was recently shown to occur. At the first location, near the village of Sleen in the east of the Netherlands, gas migration resulted from a blowout that occurred in 1965 (Schout et al., 2018). At the second location, in a village called Monster in the west of the Netherlands, gas migration was detected above a fully decommissioned cut-and-buried gas well (Schout et al., 2019). This leak was more recently closed off by the responsible operator, in accordance with Dutch law. 
Hydrogeologically, these two locations are quite different as they are situated at opposite ends of the Netherlands (Figure S2). Hence, they serve as two distinct case studies used to investigate the effects of horizontal layering on gas migration. However, it is important to note here that the goal is not to reproduce exactly the leakage conditions at these sites, as required information about the depth and magnitude of the leaks is not known.

Lithological and permeability data were retrieved from the publicly available national hydrogeological model REGIS II (Vernes \& van Doorn, 2005). REGIS II divides the subsurface into sandy, complex, and clayey layers. Complex layers typically consist of successions of more and less permeable sediments that are taken together as one regional layer. As a result, they often have a large anisotropy with a much lower vertical than horizontal permeability. Where not given, anisotropy was assumed to be 5 for sandy layers and 10 for clay layers. Porosities were assumed to be $30 \%$ for sandy layers, 35\% for complex layers, and $40 \%$ for clay layers. The Brooks-Corey pore size distribution index was assumed to be 1.5 for sandy layers, following the experimentally determined value for the sand used in the base case scenario. Accordingly, a smaller pore size distribution index was chosen for the clayey (0.75) and for complex (0.5) layers, reflecting the larger variation in pore sizes that may be expected for such lithologies. The Leverett J-function (Eq. 7) was used to scale the entry pressure based on the ratio between porosity and permeability. Separate reference values were used for the complex, sandy and clayey units (Table S1).

$$
J\left(S_{w}\right)=p_{c}\left(S_{w}\right) \sqrt{k / \phi}
$$

The bedrock at the Sleen site can be considered the top of the Breda Formation at $126 \mathrm{~m}$ depth. The case study modelled after this site was therefore constructed from this interface up to the surface. At the Monster location, the thick clay unit below the base of the Maassluis formation at $231 \mathrm{~m}$ depth was considered as the bedrock. Furthermore, the surficial Holocene deposits (55 $\mathrm{m}$ thick) are not included in the model as REGIS II does not provide data on them. The modelled section is therefore $176 \mathrm{~m}$ thick. The resulting hydrogeological input data used for both case studies is shown in Figure 2. For each case two simulations were carried out, one with a groundwater head gradient of $25 \mathrm{~cm} \cdot \mathrm{km}^{-1}$ and one with $100 \mathrm{~cm} \cdot \mathrm{km}^{-1}$, on top of the hydrostatic pressure. A flow rate of $10 \mathrm{~m}^{3} \mathrm{CH}_{4}^{\mathrm{atm}} \cdot \mathrm{d}^{-1}$ was assumed for all simulations. Otherwise, the boundary and initial conditions were kept equal to those used in the sensitivity analysis. The width of the model was extended to $80 \mathrm{~m}$ to avoid gas phase pools below interfaces of entry pressure or permeability reaching the boundaries of the model. Given the extended size of these models and the more complex hydrogeology, grid refinement was slightly reduced to $1 \times 1 \times 1 \mathrm{~m}$ to improve run times. 


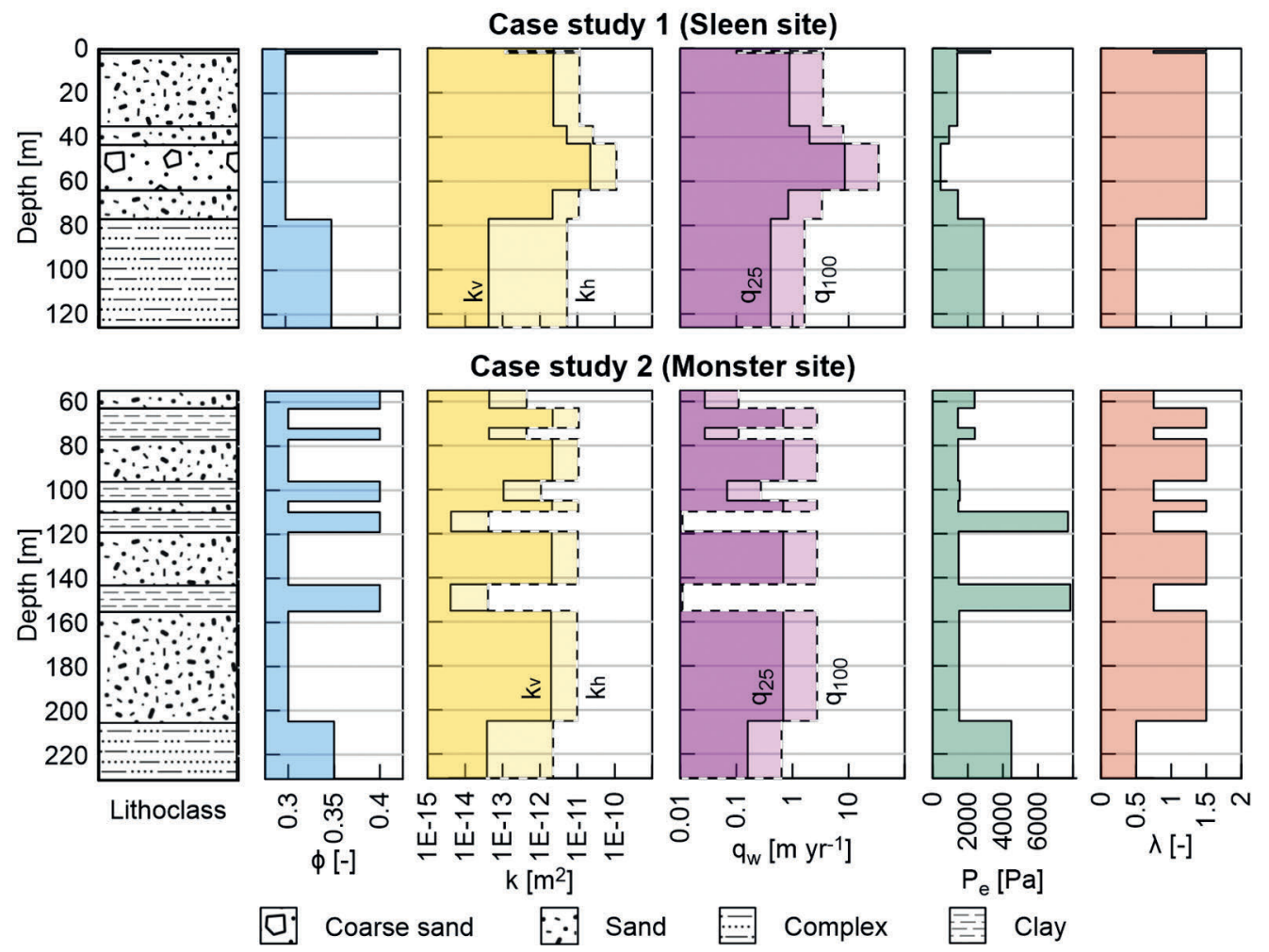

Figure 2 | Hydrogeological input data used for construction of the two layered case studies. In the permeability plot, the solid line (' $\left.k_{v}{ }^{\prime}\right)$ and dashed line $\left({ }^{\prime} k_{h}{ }^{\prime}\right)$ show the vertical and horizontal permeability, respectively. In the Darcy velocity plot, the solid line $\left({ }^{\prime} \mathrm{q}_{25}{ }^{\prime}\right)$ and dashed line $\left({ }^{\prime} \mathrm{q}_{100}{ }^{\prime}\right)$ show the modelled Darcy velocities resulting from the cases with groundwater head gradients of 25 and $100 \mathrm{~cm} \cdot \mathrm{km}^{-1}$, respectively.

\section{$5.3 \mid$ RESULTS}

First, an assessment of the potential for methane retention in the subsurface is briefly presented, and the relative magnitude of forces relevant to methane migration for the unconsolidated aquifers under study. Then, the results of the sensitivity analysis are presented, followed by the results of hydrogeologically layered case studies.

\subsubsection{Dimensional analysis of methane retention and migration}

Within the range of temperature and pressure considered in this study, that result from a maximum depth of $480 \mathrm{~m}$ below water table, methane aqueous solubility and gas phase density increase from 31 to $1112 \mathrm{mg} \cdot \mathrm{L}^{-1}$ and 0.69 to $32.3 \mathrm{~kg} \cdot \mathrm{m}^{-3}$, respectively (Figure S3). While methane mass density as a gas phase is much greater than its solubility at equal depths, the mass stored in the aqueous phase is roughly equal at gas phase saturations of $4 \%$ (Figure 3). For gas saturations exceeding $4 \%$, retention in the gas phase starts to rapidly 
exceed aqueous retention. At a gas saturation of $4 \%$ and a depth of $60 \mathrm{~m}$ below the water table, the cumulative storage in both phases is $\sim 0.2 \mathrm{~kg} \cdot \mathrm{m}^{-3}$ (Figure 3 ). In comparison, the flow rate in our base case scenario is $0.1 \mathrm{~m}^{3} \mathrm{CH}_{4}{ }^{\text {atm }} \cdot \mathrm{d}^{-1}$, equal to a methane mass flow rate of $0.07 \mathrm{~kg} \cdot \mathrm{d}^{-1}$ or flux of $\sim 0.02 \mathrm{~kg} \cdot \mathrm{m}^{-2} \cdot \mathrm{d}^{-1}$ (given the inlet area of $4 \mathrm{~m}^{2}$ ). Therefore, at this depth, it would require 10 days to saturate $1 \mathrm{~m}^{3}$ of aquifer with methane, assuming a gas saturation of $4 \%$. Although this is just a first approximation, which notably does not take into account the replenishment of available ground water for methane to dissolve in due to groundwater flow, it confirms that there is indeed potential for subsurface methane retention to significantly affect the monitorability of gas migration originating at depth.

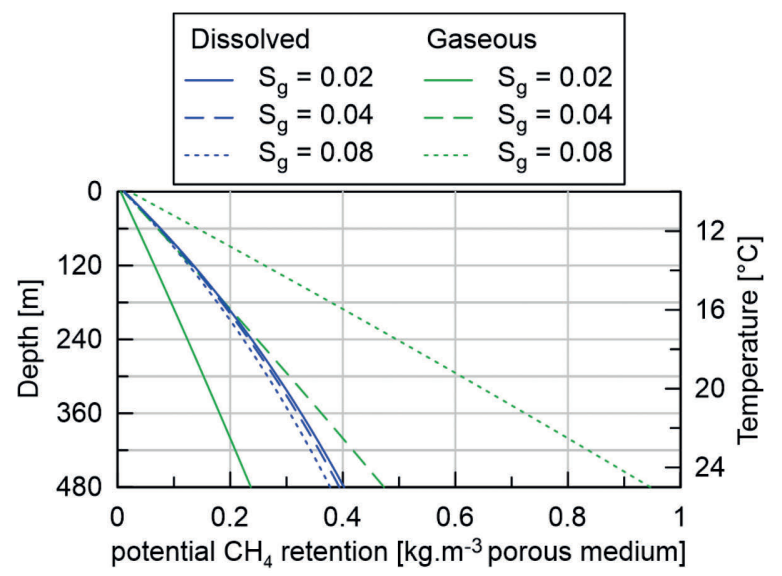

Figure 3 | Potential mass density of methane as a gas phase (green lines) or in the aqueous phase (blue lines) as a function of depth, for three different values of the gas phase saturation $\left(\mathrm{S}_{\mathrm{g}}\right)$. Temperature is based on a thermal gradient of $31.3^{\circ} \mathrm{C} \mathrm{km}^{-1}$ and a porosity of $38 \%$ was assumed, equal to that of the base case scenario.

Following the definitions in Kopp (2009) a dimensional analysis of the balance of forces in the system was carried out. Preliminary testing showed that for the gas migration velocities encountered in our sensitivity analysis, viscous forces were insignificant compared to both gravity and capillary forces. Hence, the system is characterized by the dimensionless Bond number:

$$
\text { Bo }=\frac{\text { capillary forces }}{\text { gravitational forces }}=\frac{p_{c r}}{\left(\rho_{w}-\rho_{g}\right) g l_{c r}}
$$

where $p_{c r}$ and $l_{c r}$ are the critical pressure and length, respectively, and $g$ is the gravity constant (9.81 $\left.\mathrm{m} . \mathrm{s}^{-2}\right)$. The critical pressure is defined as the capillary pressure drop over the saturation front length and is therefore roughly equal to entry pressure. Typically, for advection-driven flow systems, the critical length is taken to be equal to the length of the saturation front width (Kopp, 2009). When assuming a critical length equal to the discretization length $(0.5 \mathrm{~m})$, capillary forces equal gravitational forces for entry pressure values of $5 \mathrm{kPa}$ (Figure S4). This shows that for the three sands considered in the sensitivity analysis, which have a maximum entry pressure of $3.9 \mathrm{kPa}$ (Table 1), gravitational forces likely dominate. However, 
the complex and clayey layers in the hydrogeologically layered case studies have a maximum entry pressure of $7.8 \mathrm{kPa}$ (Figure 2). Depending on the actual width of the saturation front, capillary forces likely exceed gravitational forces for these clayey sediments.

\subsubsection{Sensitivity analysis}

\subsubsection{Retention by $\mathrm{CH}_{4}$ dissolution}

In the base case scenario (Table 1) the upward, buoyancy-driven migration of the gas plume from the base of the simulated aquifer to its top (60 m interval) takes 1.65 years (Figure $4 a$ and Table 2). Due to the coarse grain size and relatively low methane flux, migration is mostly vertical and the gas phase stays within the column overlying the inlet boundary. This observation is in line with the findings of the dimensional analysis, and confirms that gravitational forces indeed dominate in this case. Maximum gas phase saturations remain low at only $2.4 \%$. As the gas phase migrates, the surrounding water column is saturated throughout, and methane saturated groundwater is advectively transported away from the gas phase plume, allowing more gaseous methane to be dissolved (Figure 5). Migration time reduces to 1.14 years when the Darcy velocity in the aquifer is reduced to zero (scenario 2) and just 0.35 years if in addition the initial concentration of methane throughout the aquifer is raised from 0 to $95 \%$ of the solubility (scenario 3). Therefore, methane dissolution, from the bottom to the top of a $60 \mathrm{~m}$ thick sandy aquifer with a groundwater Darcy velocity of only $1 \mathrm{~m} . \mathrm{yr}^{-1}$, causes the migration of a $0.1 \mathrm{~m}^{3} \mathrm{CH}_{4}{ }^{\text {atm }} \cdot \mathrm{d}^{-1}$ leak to occur 1.3 years more slowly than it would have without dissolution.

The difference in results of the first three scenarios is more pronounced when looking at the percentage of inflowing methane that exits the model through the top boundary $\left(Q_{\text {out }} / Q_{\text {in }}\right)$. For scenario 3, $Q_{\text {out }} / Q_{\text {in }}$ reaches $82 \%$ in a year and goes to $100 \%$ after approximately 5 years (Figure 4a). Ultimately, this fraction even slightly exceeds $100 \%$ as some of the initially dissolved methane also passes through the top boundary (Figure 4a). For scenario 2, when both the initial methane concentration and groundwater velocity are zero, $Q_{\text {out }} / Q_{\text {in }}$ increases gradually with time to $91 \%$ after 20 years. The remaining $9 \%$ is trapped in the aquifer by dissolution and subsequent diffusion away from the gas phase plume. With time, this fraction would steadily increase further as the aquifer saturates with methane and the rate of diffusion slows down. However, for the base case scenario these outcomes are entirely different, as $\mathrm{Q}_{\text {out }} / \mathrm{Q}_{\text {in }}$ stabilizes after 4 years when just $10 \%$ of the imposed methane flow rate migrates on through the top boundary. This shows that dissolution in combination with advective transport exerts a much stronger control on gas migration than dissolution with diffusive transport, even for groundwater with a Darcy velocity of only $1 \mathrm{~m} . \mathrm{yr}^{-1}$.

\subsubsection{2 | Impact of methane flow rate}

The relative impact of dissolutive retention is significantly reduced when increasing the methane flow rate through the inlet by a factor of 10 , from 0.1 to $1 \mathrm{~m}^{3} \mathrm{CH}_{4}{ }^{\mathrm{atm}}$. $\mathrm{d}^{-1}$ (scenario 4). While maximum gas phase saturations increased to $4.6 \%$, migration is still primarily vertical and migration time reduced from 1.65 year in the base case scenario to just 0.16 year 
(Table 2). Therefore, a smaller fraction of migration methane can be dissolved and retained in the aquifer, given that the groundwater velocity was kept equal, and $Q_{\text {out }} / Q_{\text {in }}$ stabilizes after just 2 years at $85 \%$ compared to 4 years and $10 \%$ in the base case scenario (Figure $4 a$ ).

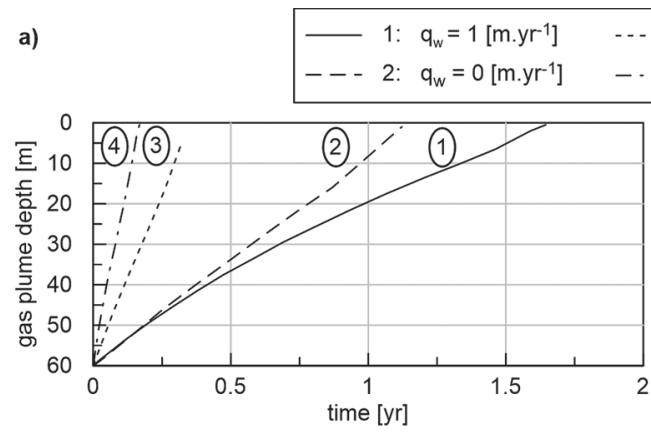

$$
\begin{aligned}
& \text { 3: } \left.q_{w}=0\left[m \cdot y r^{-1}\right], x_{i}^{C H 4} / x_{\max }{ }^{C H 4}=95 \%\right) \\
& \text { 4: } q_{w}=1\left[m \cdot y r^{-1}\right], Q_{i n}=1\left[m^{3} \cdot d^{-1}\right]
\end{aligned}
$$

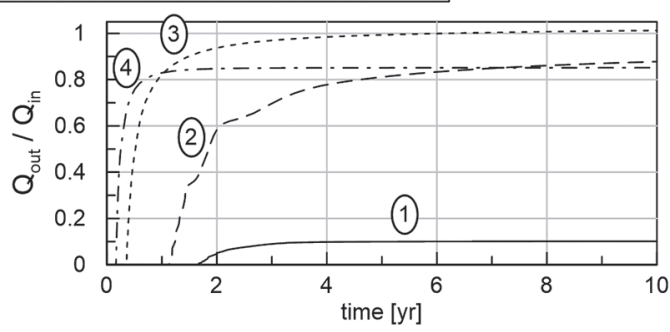

b)

$$
\begin{array}{llllll}
- & 4: & q_{w}=1\left[m \cdot y r^{-1}\right], Q_{i n}=1\left[m^{3} \cdot d^{-1}\right] & \cdots- & 8: & q_{w}=100\left[m \cdot y r^{-1}\right], Q_{i n}=1\left[m^{3} \cdot d^{-1}\right] \\
--- & 7: & q_{w}=10\left[m \cdot y r^{-1}\right], Q_{i n}=1\left[m^{3} \cdot d^{-1}\right] & \ldots . . & 9: & q_{w}=100\left[m \cdot y r^{-1}\right], Q_{i n}=10\left[m^{3} \cdot d^{-1}\right]
\end{array}
$$
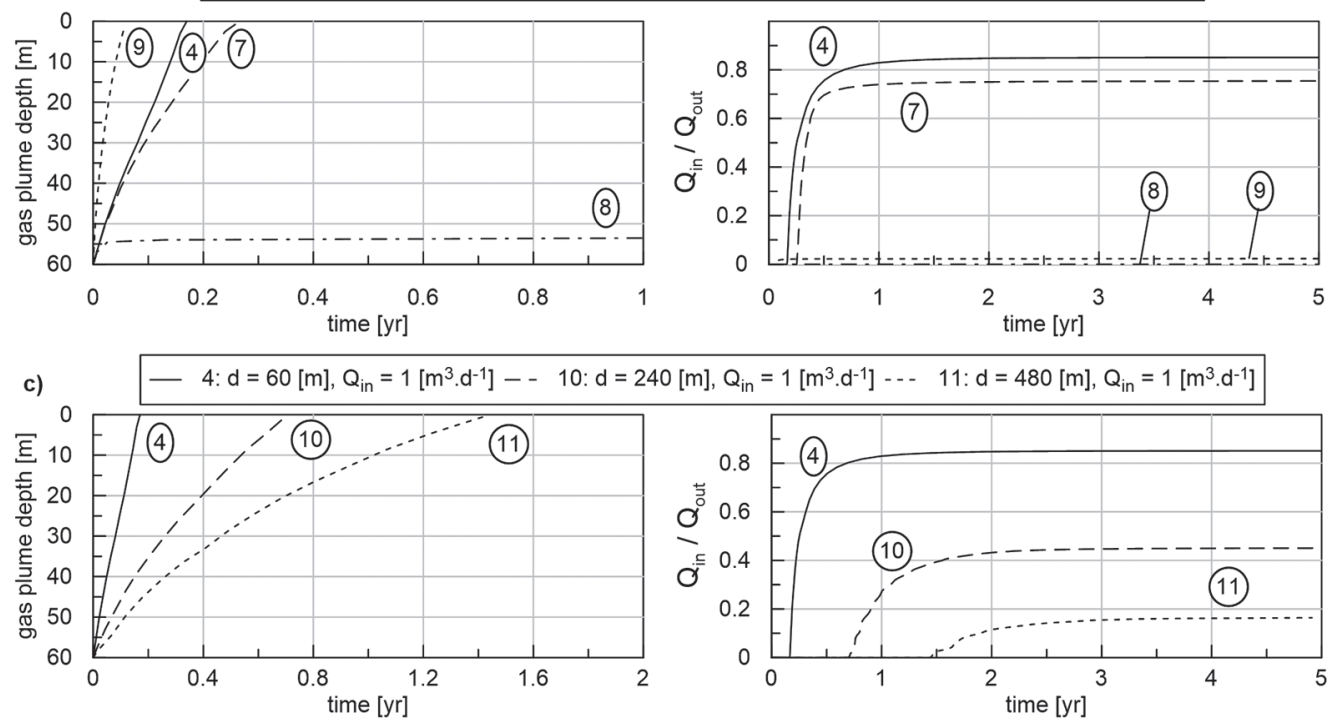

Figure 4 | Vertical propagation of the gas phase plume (left) and fraction of inflowing methane that exits $\left(\mathrm{Q}_{\text {out }} / \mathrm{Q}_{\text {in }}\right)$ the domain through the top boundary (right). Results for scenarios $1-4$ are shown in figure a, scenarios 4, 7, 8 and 9 in figure b, and scenarios 4, 10 and 11 in figure c. Lines are labelled according to the corresponding scenario numbers in Table 1, with simulated variations with respect to the base case indicated in figure legends. 


\subsubsection{3 | Impact of sand properties}

Due to the smaller permeability, larger entry pressure and smaller pore size distributions of the finer grained sands simulated in scenarios 5 and 6 (Table 1), gas phase propagation patterns are changed considerably with respect to the base case (Figure 5). Particularly for the case of a very fine sand (scenario 6), with a 10 times smaller pore size distribution index ( 0.15 versus 1.5 in the base case), the gaseous plume becomes more rounded (Figure $5 a$ ). This also leads to some minor upstream migration of the gas phase, and is the result of an increase in capillary force, which acts in all directions equally, relative to the gravitational force, which acts only vertically upwards. In the fine sand case (scenario 5), both vertical and horizontal permeabilities are $\sim 7$ times lower than in the base case. Due to this increased resistance to flow, the maximum gas phase saturation becomes higher than in the base case: $3.0 \%$ versus $2.4 \%$. The gas phase can be seen to migrate slightly along with groundwater flow in both scenarios with finer average grain sizes (Figure 5b). Ultimately, the change in shape and decreased speed of upward propagation allows more methane to be dissolved in both cases, given that Darcy velocities were kept equal. This causes the gas phase propagation to stagnate at $6.5 \mathrm{~m}$ and $18.5 \mathrm{~m}$ below the top of the model domain for the fine sand and the very fine sand cases, respectively (Table 2 ). Hence, $Q_{\text {out }} / Q_{\text {in }}$ remains 0 . The distance with which methane has been transported at the base of the model is $28 \mathrm{~m}$ in the base case scenario, $24 \mathrm{~m}$ in scenario 5 and $34 \mathrm{~m}$ in scenario 6 , calculated from the inlet at $\mathrm{x}=42 \mathrm{~m}$ to where the concentration equals half that of the solubility at $60 \mathrm{~m}$ depth $\left(204 \mathrm{mg} \cdot \mathrm{L}^{-1}\right)$. The difference between these distances is caused by the differences in porosity, resulting in varying effective groundwater velocities. It should be noted that due to diffusion, the distance where methane concentrations are sufficiently large to be readily detected in groundwater samples $\left(\sim 0.1 \mathrm{mg} \cdot \mathrm{L}^{-1}\right)$ is almost twice as large (Figure $5 \mathrm{~b}$ ).

\subsubsection{4 | Impact of groundwater flow velocity}

Gas migration resulting from a $1 \mathrm{~m}^{3} \mathrm{CH}_{4}{ }^{\text {atm }} \cdot \mathrm{d}^{-1}$ flow rate is not impacted greatly when raising groundwater velocity from 1 to $10 \mathrm{~m} \cdot \mathrm{yr}^{-1}$ (scenarios 4 and 7). Migration time increases from 0.16 to 0.25 year and $Q_{\text {out }} / Q_{\text {in }}$ is reduced from $85 \%$ to $76 \%$ (Table 2). However, when groundwater velocity is further increased to $100 \mathrm{~m} . \mathrm{yr}^{-1}$ (scenario 8 ), the gas plume movement is severely impacted and migration stagnates at $53.5 \mathrm{~m}$ below the top of the aquifer, having moved up just $6.5 \mathrm{~m}$ (Figure 4b). The impact of a $100 \mathrm{~m} . \mathrm{yr}^{-1}$ groundwater flow velocity was also assessed for an even higher methane flow rate of $10 \mathrm{~m}^{3} \mathrm{CH}_{4}{ }^{a t m} \cdot \mathrm{d}^{-1}$ (scenario 10). The higher flow rate results in larger maximum gas saturations (6.2\%) and much more rapid gas phase migration, as the top of the aquifer was reached in 0.06 years. However, $Q_{\text {out }} / Q_{\text {in }}$ stabilized at just $2 \%$. This shows that even large gaseous flow rates can be severely impacted by dissolutive retention, in spite of a very rapid upward migration of the gas phase. 

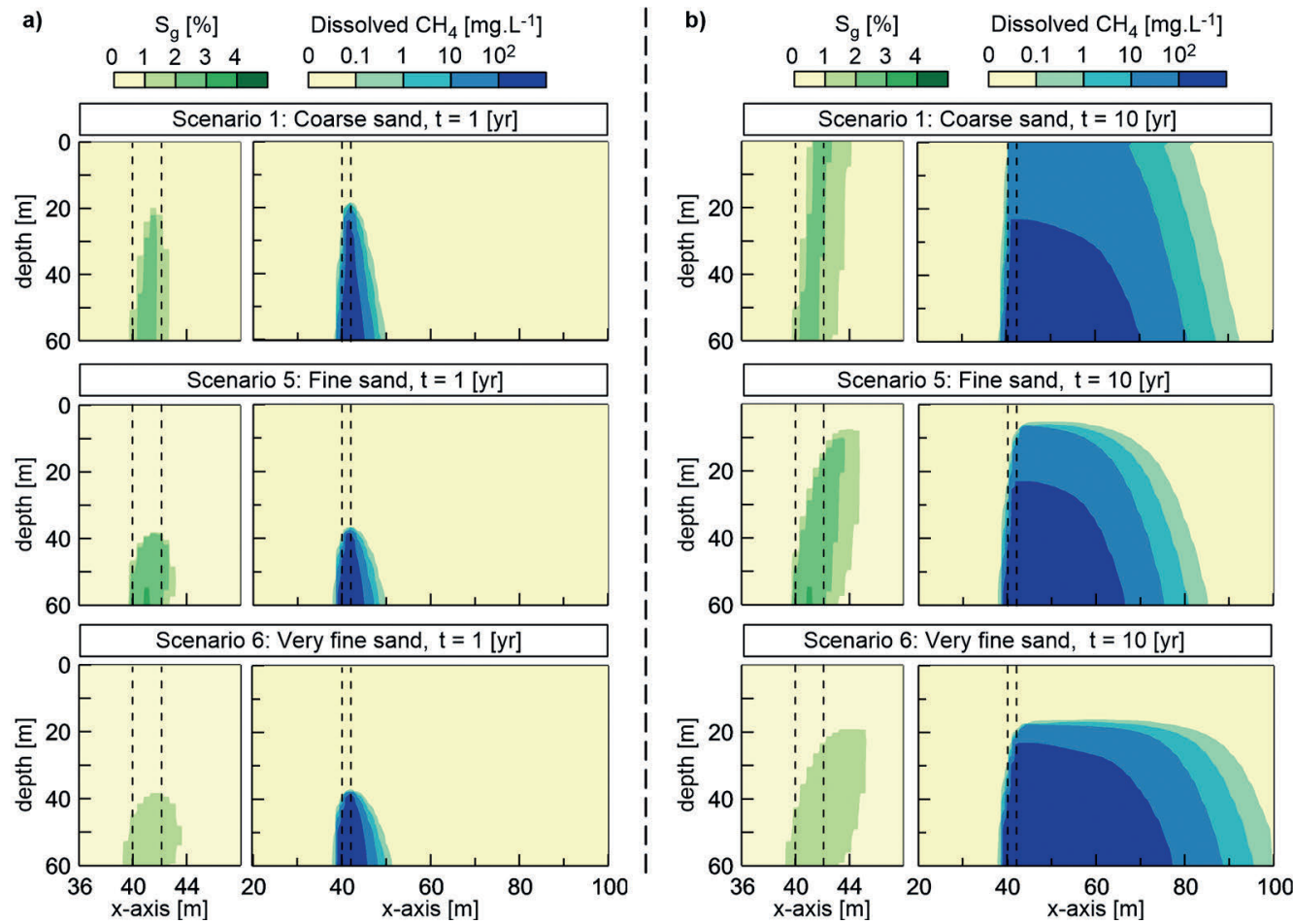

Figure 5 | Cross sections of the gas phase saturation (green) and dissolved $\mathrm{CH}_{4}$ mass concentration (blue) after simulated times of 1 year (a) and 10 years (b). Results are shown for the case of a coarse sand, fine sand and very fine sand, corresponding to scenarios 1, 5 and 6 (Table 1). Vertical dashed lines indicate the relative position of the $\mathrm{CH}_{4}$ inlet boundary at the base of the model at $60 \mathrm{~m}$ depth.

\subsubsection{Impact of aquifer depth}

The depth of the aquifer was increased 4 and 8 times in scenarios 11 and 12, respectively, resulting in an increased depth of the base of the aquifer of $240 \mathrm{~m}$ and $480 \mathrm{~m}$ depth (aquifer thickness remains $60 \mathrm{~m}$ ). Simulations were run with a methane flow rate of $1 \mathrm{~m}^{3} \mathrm{CH}_{4}{ }^{\mathrm{atm}} \cdot \mathrm{d}^{-1}$, and are thus compared to that of scenario 4 (Table 1). The average methane solubility over the resulting depth intervals is 4.8 and 8.6 times higher than in the base case scenario, and the average gas phase density increases 5.3 and 10.9 times (Figure S3). Both aqueous and gaseous retention capacity is therefore greatly increased at these depths and model outcomes are indeed significantly changed, as migration time to the top of the aquifer increased from 0.16 year to 0.7 year at $240 \mathrm{~m}$ depth and 1.45 year at $480 \mathrm{~m}$ depth (Table 2). By extension, $Q_{\text {out }} / \mathrm{Q}_{\text {in }}$ stabilized later and decreased from $85 \%$ to $45 \%$ at $240 \mathrm{~m}$ depth and to $16 \%$ at $480 \mathrm{~m}$ depth (Figure 4 ). 


\subsubsection{6 | Impact of the residual gas saturation}

In scenario 12 the residual gas saturation was lowered to $0 \%$. Migration time to the top of the aquifer decreased to 1.09 years, compared to 1.65 years in the base case scenario. $\mathrm{Q}_{\text {out }} / \mathrm{Q}_{\text {in }}$ increased from 10 to $16 \%$. This shows that even very small variations in residual gas saturation impact gas retention and migration. In scenario 13 the residual gas saturation was raised to $15 \%$. As the residual gas saturation acts as a sort of threshold value, below which flow cannot start, this causes gas phase saturations to become much larger than in the base case scenario, and thus more gas is stored in the porous medium. Migration of the gas phase plume slows down considerably and had nearly stagnated after 20 years of simulation at a depth of $4 \mathrm{~m}$ below the top of the aquifer (Table 2).

\subsubsection{7| Impact of anisotropy}

Variations in anisotropy were modelled by raising the vertical permeability to equal the horizontal permeability in scenario $14\left(\mathrm{k}_{\mathrm{h}} / \mathrm{k}_{\mathrm{v}}=1\right)$ and lowering it to $1 / 10^{\text {th }}$ of the horizontal permeability in scenario $15\left(k_{h} / k_{v}=10\right.$, Table 1$)$. The expected higher and lower gas migration speed results in the gas reaching the top of the aquifer in only 0.80 years for the lower anisotropy case and in 3.19 years in the higher anisotropy case, compared to 1.65 in the base case scenario (Table 2). In turn, the change in gas migration velocity affects the amount of methane that is dissolved and $\mathrm{Q}_{\text {out }} / \mathrm{Q}_{\text {in }}$ after 20 years of leakage changes to $24 \%$ and $2 \%$ for scenarios 14 and 15 , respectively.

\subsubsection{Impact of the area over which the influx occurs}

The results of earlier simulations and the dimensional analysis demonstrate that for the flow rates considered in this study and parameter values typical of sandy aquifers, buoyancy driven, vertical gas migration dominates. As a consequence, the degree of dissolutive retention is not only related to the groundwater velocity, flow rate, and sediment properties, but also depends on the area of the inlet. This determines the leakage flux $\left(\mathrm{L}^{3} \cdot \mathrm{L}^{-2} \cdot \mathrm{d}^{-1}\right)$ and hence the amount of water that is available for methane to dissolve in. To investigate the importance of this effect, the inlet boundary size was reduced from $2 \times 2 \mathrm{~m}^{2}$ to $1 \times 1 \mathrm{~m}^{2}$ in scenario 16 , while keeping $Q_{\text {in }}$ equal. Upward migration velocity increased considerably and gas reached to the top of the aquifer in 1.12 years while $Q_{\text {out }} / \mathrm{Q}_{\text {in }}$ after 20 years increased to $20 \%$, compared 1.65 years and $10 \%$ in the base case. When increasing the inlet area to $4 \times 4 \mathrm{~m}^{2}$ (scenario 17), migration velocity was significantly reduced such that stagnation occurred at $17 \mathrm{~m}$ below the top of the aquifer (Table 2). 


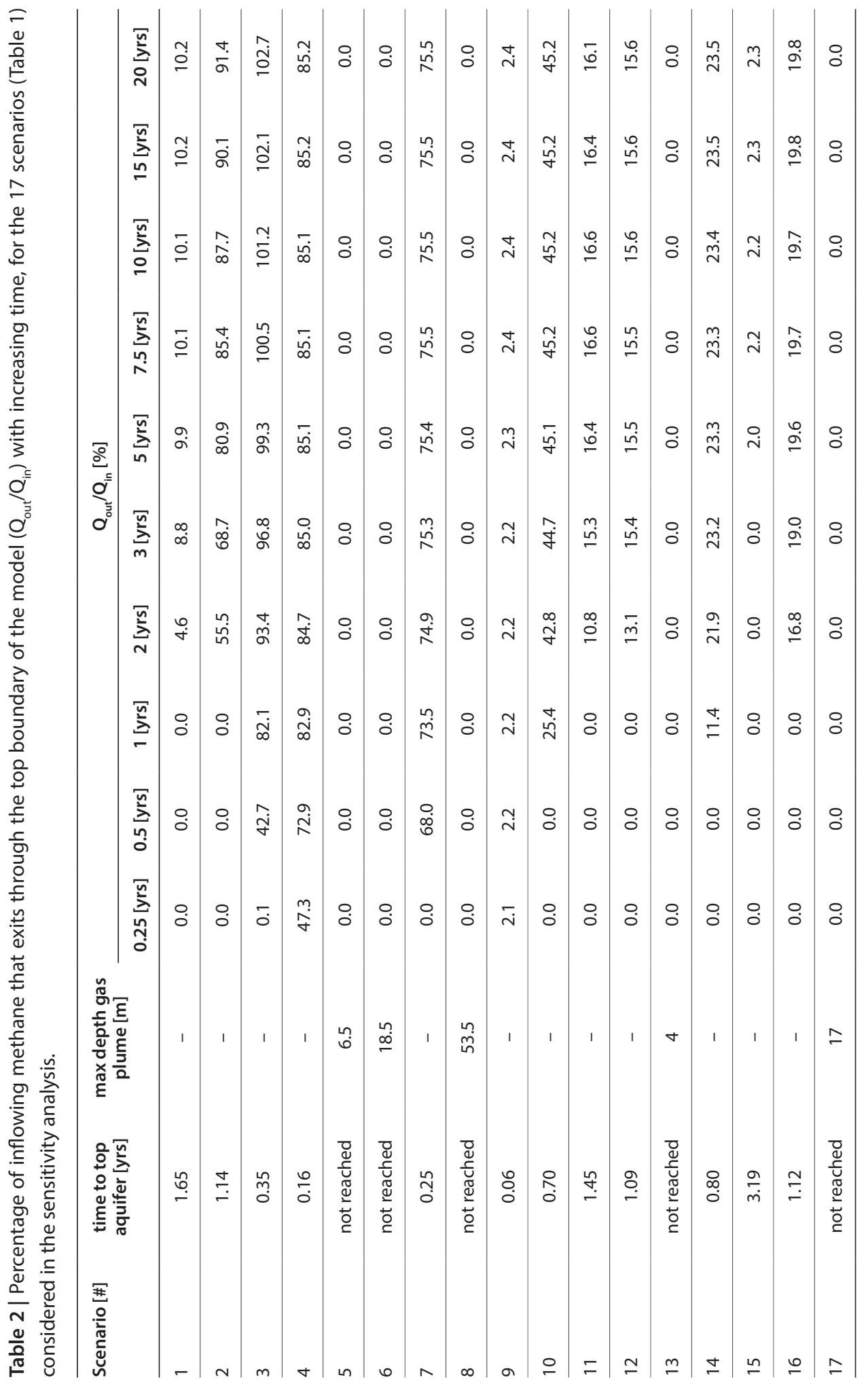




\subsubsection{Layered case studies based on real sites}

\subsubsection{1 | Case study 1: Sleen site}

The modelling domain of the first case study consists of a simplified hydrogeology with 7 main layers, cumulatively $126 \mathrm{~m}$ thick (Figure 2). The lowest layer is characterized by a high anisotropy factor of $125\left(\mathrm{k}_{\mathrm{h}} / \mathrm{k}_{\mathrm{v}}\right)$ and low vertical permeability of $4.2 \cdot 10^{-14} \mathrm{~m}^{2}$. This complex layer is overlain by 5 sandy sections with slightly varying permeabilities. Notably, the third layer from the bottom is a coarse sand and has the highest horizontal permeability of $1.1 \cdot 10^{-10} \mathrm{~m}^{2}$. The sandy units are only interbedded by a $1 \mathrm{~m}$ thick complex layer with a low vertical permeability from 1 to $2 \mathrm{~m}$ depth. Two scenarios were carried out using this parametrization, one with a constant head gradient of $0.25 \mathrm{~m} \cdot \mathrm{km}^{-1}$ and the other with $1 \mathrm{~m} \cdot \mathrm{km}^{-1}$. Given the constant head gradient, groundwater velocities in the coarse sandy layer are highest, with Darcy velocities of 8.6 and $34.2 \mathrm{~m} . \mathrm{yr}^{-1}$ in the first and second scenario, respectively (Figure 2 ).

The low $\mathrm{k}_{\mathrm{v}}$ in the highly anisotropic bottom layer causes significant lateral spreading of the methane plume to occur, with gas phase saturations greater than $6 \%$ close to the inlet. In the $0.25 \mathrm{~m} \cdot \mathrm{km}^{-1}$ head gradient scenario, this spreading occurs more or less symmetrically in each direction (Figure 6). In the $1.00 \mathrm{~m} \cdot \mathrm{km}^{-1}$ scenario the plume is tilted more strongly in the direction of groundwater flow. Gas migration through this $49 \mathrm{~m}$ thick layer takes roughly 3.2 years in both scenarios. In comparison, migration through the remaining $77 \mathrm{~m}$ thick modelling domain occurs in only 1.9 years in the first scenario (Table S2). Dissolution of gaseous methane in the horizontally flowing groundwater is highly significant, as evidenced by the stagnation of the gas phase plume in the high permeability coarse sand layer in the $1.00 \mathrm{~m} . \mathrm{km}^{-1}$ scenario (Figure 6). The high groundwater velocities here, combined with the lateral spreading of the methane plume that occurs in the underlying layers, causes the $10 \mathrm{~m}^{3} \mathrm{CH}_{4}{ }^{\text {atm }} \cdot \mathrm{d}^{-1}$ flow rate to be completely dissolved once the plume reaches a depth of around $52 \mathrm{~m}$. In the $0.25 \mathrm{~m} \cdot \mathrm{km}^{-1}$ scenario, $Q_{\text {out }} / \mathrm{Q}_{\text {in }}$ stabilizes after 20 years at $41 \%$ (Table $\mathrm{S} 2$ ). The radius of the gaseous plume at the top of the simulated section (which in this case represents the groundwater table) reaches a maximum value of around $20 \mathrm{~m}$, and is slightly elongated in the direction of groundwater flow.

\subsubsection{2 | Case study 2: Monster site}

Similar to the first case study, the lowest layer of the second case study consists of a complex unit with a low vertical permeability and high anisotropy. However, the overlying stratigraphy is notably different than in the first case study and is characterized by the presence of 5 low permeability, high entry pressure clay layers that alternate the sandy aquifers (Figure 2). Particularly the first and second clay layers from the bottom, at depths of $155-143 \mathrm{~m}$ and 119 - $110 \mathrm{~m}$, have much lower vertical permeabilities $\left(\sim 4 \cdot 10^{-15} \mathrm{~m}^{2}\right)$. Accordingly, they are also assigned higher entry pressures $(\sim 7.8 \mathrm{kPa})$ than the sandy units, and the values considered in the sensitivity analysis. The sandy aquifers are also slightly less permeable than in the first

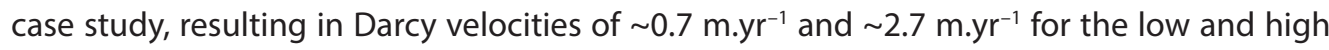
head gradient scenario's, respectively. The modelled section is $176 \mathrm{~m}$ thick, and the top of the 
model is at $55 \mathrm{~m}$ depth. Gas migrating through the top boundary would enter the overlying Holocene deposits, which were not considered in our simulations.

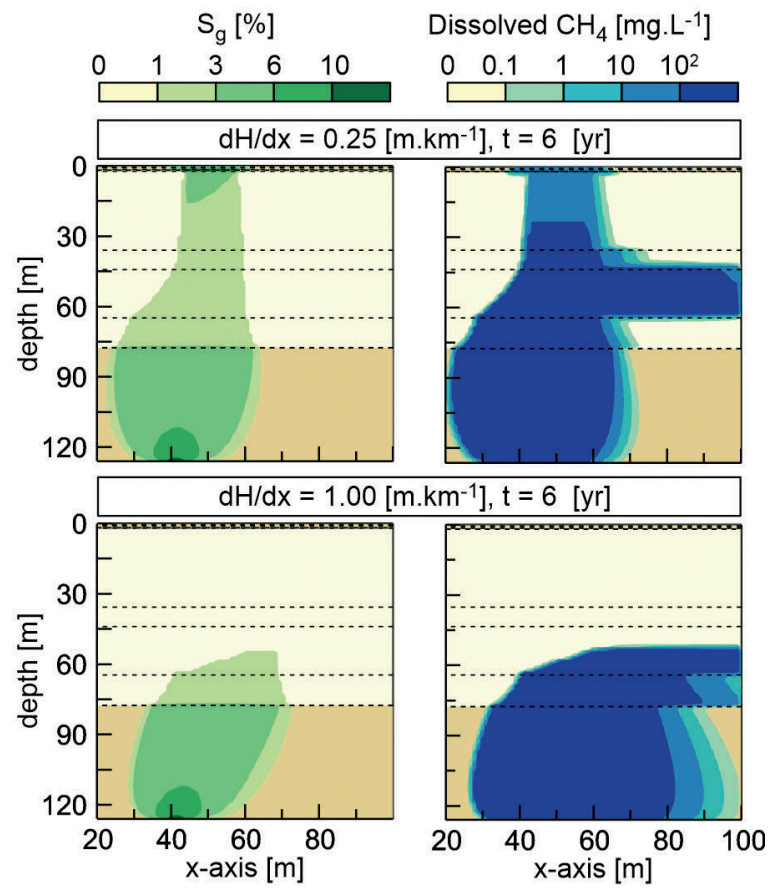

Figure 6 | Gas phase saturation and dissolved $\mathrm{CH}_{4}$ mass concentration after 6 years of a $10 \mathrm{~m}^{3} \mathrm{CH}_{4}{ }^{\text {atm }} \cdot \mathrm{d}^{-1}$ leakage rate for the first case study site ('Sleen'). Top figures shows the results of the scenario with a head gradient of 0.25 $\mathrm{m} . \mathrm{km}^{-1}$, lower figure for the scenario with a head gradient of $1 \mathrm{~m} \cdot \mathrm{km}^{-1}$. Horizontal dashed lines delineate the different hydrogeological layers (Figure 2), with darker shaded layers representing the clayey and complex layers that have a higher entry pressure and a lower permeability than the sandy layers.

As in the first case study, the complex unit at the base of the model causes substantial lateral spreading (Figure 7). After around 3 years, the migrating gas phase encounters the first clay layer which results in significant gas phase pooling. Invasion of the clay layer only occurs after gaseous saturations exceed $6 \%$. At that saturation, the combined capillary and gravitational forces were large enough to overcome the entry pressure barrier. In the low head gradient scenario, this gaseous pool grows to saturations exceeding $10 \%$ and a diameter of roughly $70 \mathrm{~m}$. In the high head gradient scenario, less pooling occurs due to the larger amount of methane that is already dissolved in the underlying units. However, the pool is more extensive in the direction of groundwater flow. Similar behavior is observed at the $2^{\text {nd }}$ clay layer, but entry pressures assigned to the remaining three clay layers were not sufficient to cause significant pooling. In the low head gradient scenario, the gas phase plume reaches the top of the modelled domain after 16.2 years. Even at the end of the 50 year simulation time, $Q_{\text {out }} / \mathrm{Q}_{\text {in }}$ had not fully stabilized reaching a value of $46.3 \%$ (Table S2). Due to the relatively slow upward migration, pooling of gas below the clay layers, and low groundwater velocities in the clay layers, the dissolved methane plume takes on a pine tree-like shape (Figure 7). In the high head gradient scenario, gas phase migration stagnates 
at $103 \mathrm{~m}$ depth, or $48 \mathrm{~m}$ below the top of the modelling domain. Notably, the center of the gaseous plume at that depth can be seen to have shifted by roughly $30 \mathrm{~m}$ in the direction of groundwater flow. This is caused by the imposed hydraulic gradient, which results in slightly lower water pressures downstream. Given that the entry pressure is defined as $P_{e}=P_{g}-P_{\mu}$, the migrating gas will preferentially invade cells those cells and the plume shifts in the direction of groundwater flow.

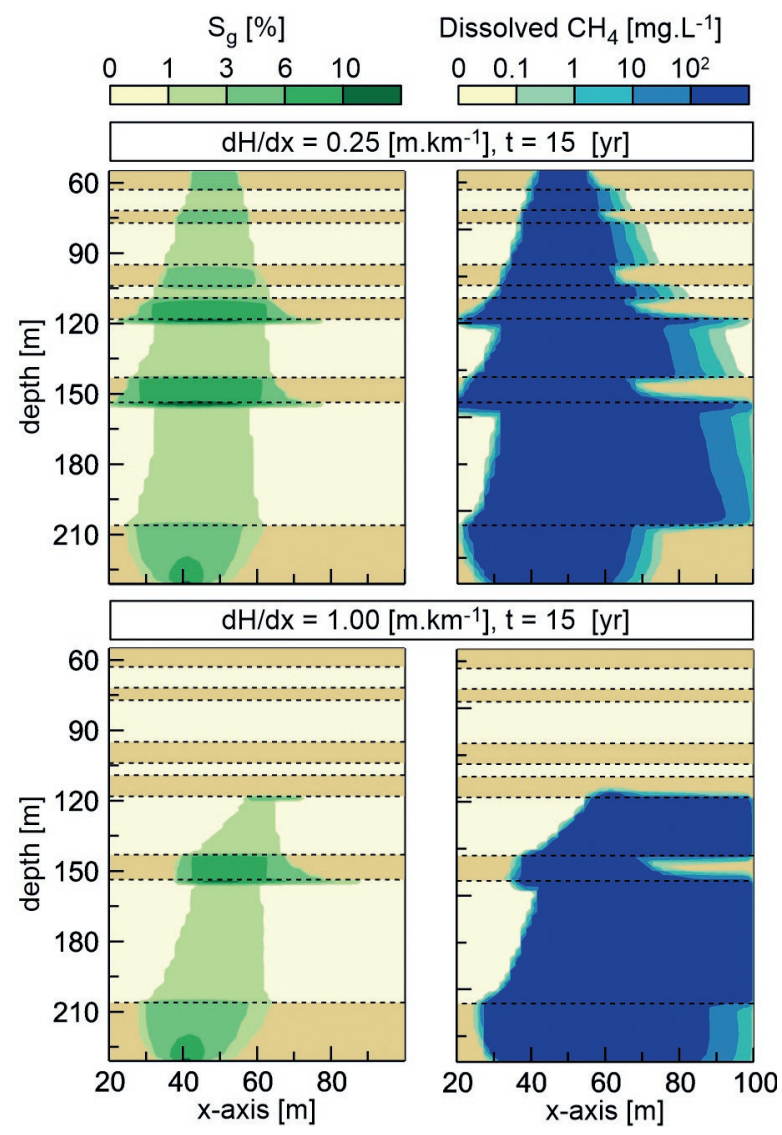

Figure 7 | Gas phase saturation and dissolved $\mathrm{CH}_{4}$ mass concentration after 15 years of a $10 \mathrm{~m}^{3} \mathrm{CH}_{4}{ }^{\text {atm }} \cdot \mathrm{d}^{-1}$ leakage rate for the second case study site ('Monster'). Top figures show the results of the scenario with a head gradient of $0.25 \mathrm{~m} . \mathrm{km}^{-1}$, lower figures for the scenario with a head gradient of $1 \mathrm{~m} \cdot \mathrm{km}^{-1}$. Horizontal dashed lines delineate the different hydrogeological layers (Figure 2), with darker shaded layers representing the clayey and complex layers that have a higher entry pressure and a lower permeability than the sandy layers.

\section{4 | DISCUSSION}

\subsection{1 | Upward migration and retention of methane gas}

For the simulated homogeneous sandy aquifers and leakage flow rates up to $1 \mathrm{~m}^{3} \mathrm{CH}_{4}{ }^{\text {atm }} \cdot \mathrm{d}^{-1}$, gas migration was shown to be primarily buoyancy driven and vertical (Figure 5), as expected based on an analysis of the relative magnitude of gravitational and capillary forces (Figure S4), and as observed by other researchers for weakly isotopic sandy porous media (Klazinga 
et al., 2019). A limited amount of up or down gradient flow of gas only occurred for two simulations with more fine grained sediment properties (Figure 5), due to their lower vertical permeability and an increase in capillary forces. Gas phase saturations remained low and reached up to around 5\%, depending on the imposed flow rate and permeability. At these saturations, the potential mass storage of methane in the aqueous phase is either larger than or equal to the storage in the gaseous phase (Figure 3), even without considering the additional dissolution capacity with groundwater flow.

Gaseous retention has been shown to be significant in simulations of methane migrating from gas reservoirs towards shallow aquifers, when assuming large residual gas saturations of up to $30 \%$ (Kissinger et al., 2013). However, there is little consensus on appropriate values to use for simulating gas migration through unconsolidated aquifers. While Klazinga et al. (2019) used a single value of 10\%, Rice et al. (2018) chose a negligibly small value, arguing that gas cannot be trapped during processes with strictly increasing gaseous saturations (i.e. drainage), which is the case in our numerical simulations. However, gas migration through real-world, heterogeneous sediments is likely to be a more dynamic process. As a result, intermittent periods of imbibition may still occur, particularly when leakage at the leakage point is not entirely continuous. In spite of this uncertainty, model outcomes showed relatively little sensitivity to a change in residual gas saturation from $1 \%$ to $0 \%$ (scenario 12, Table 2), because gas migration is more strongly controlled by retention in the aqueous phase at those concentrations. On the contrary, an imposed residual saturation of $15 \%$ exerted a strong control on upward gas migration leading to a much more slowly developing gas plume (scenario 13, Table 2).

\subsection{2 | Retention of methane by dissolution}

The sensitivity analysis showed that dissolutive retention of methane in unconsolidated sedimentary aquifers can play a major role in limiting upward gas migration. Even low groundwater flow velocities $\left(1 \mathrm{~m} . \mathrm{yr}^{-1}\right)$ resulted in significant methane retention (Figure 4a). On the contrary, retention was negligible in the absence of groundwater flow. This shows that it is primarily driven by advective transport of dissolved methane away from the gas phase plume, rather than diffusive transport. Hence, retention is proportional to the groundwater velocity and methane solubility. The effect of retention on methane migration was therefore also much less significant for a simulation where the initial aqueous $\mathrm{CH}_{4}$ concentration was raised to $95 \%$ solubility. In this scenario, migration time through the $60 \mathrm{~m}$ thick aquifer was just 0.35 years, compared to 1.65 years in the base case with fully unsaturated groundwater (Figure 4a). This also highlights that upward methane gas migration can be more rapid in areas with pre-occurring concentrations of dissolved methane. However, natural methane concentrations near solubility are rarely found in shallow groundwater. As an example, the methane solubility at just $60 \mathrm{~m}$ depth below the water table ( $200 \mathrm{mg} . \mathrm{L}^{-1}$, Figure S3) already exceeds the maximum concentration ever observed in Dutch shallow groundwater ( 120 mg. $\mathrm{L}^{-1}$, Cirkel et al., 2015). Hence, dissolutive retention can still be significant even for locations with relatively high methane concentrations. 
Besides groundwater velocity and initial methane concentrations, model outcomes indicate a strong control of the sediment properties and the magnitude of the leak, as they determine the velocity and dimensions of the upward migrating gas phase. For a given groundwater velocity, a more dilute or more slowly migrating gas plume allows for a larger fraction of the total flux to dissolve. Sediment properties that limit upward migration include the vertical permeability, the residual gas saturation, and the capillary pressure-saturation and relative permeability relations. Using the Brooks-Corey model, the latter two are defined by the capillary entry pressure and the pore size distribution index. Indeed, for two simulated scenarios with sediment properties associated with more finely grained sediments (D50 0.16 and $0.09 \mathrm{~mm}$, compared to $0.61 \mathrm{~mm}$ in the base case), methane migration resulting from a $0.1 \mathrm{~m}^{3} \mathrm{CH}_{4}{ }^{\text {atm }} \cdot \mathrm{d}^{-1}$ flow rate stagnated entirely due to the complete dissolution of the migrating gas plume at depth (Figure 5).

Model outcomes also show that the dimension of the inlet over which the leakage is imposed also has a strong influence. Here, we assumed that gas migrated into the model domain over a $2 \times 2 \mathrm{~m}^{2}$ area, and that the origin of the leak was somewhere below the bottom of the model domain, for example caused by gas circumvention or SCP-induced leakage (Figure 1). This also explains why retention was greatly enhanced in two simulated case studies where the sandy aquifers where alternated by sediment beds of lower permeability (Figure 2). Besides their greater thickness and depth, such layers cause significant spreading of the gaseous plume to occur, which in turn enhances dissolutive retention significantly (Figure 6 and Figure 7). Flow rates of $10 \mathrm{~m}^{3} \mathrm{CH}_{4}{ }^{\text {atm }} \cdot \mathrm{d}^{-1}$ were either completely dissolved, causing migration to stagnate well below the top of the modelled domain, or took several decades to fully develop (Table S2). Significant lateral spreading of migrating methane was also shown to occur for SCP-induced leakage originating in a low permeable shale below a shallow aquifer (Rice et al., 2018). In such conditions, our results show that more permeable overlying layers can become strong barriers to upward migration due to dissolutive retention. Conversely, the impact of dissolutive retention would be much smaller when methane migration is focused through high permeable pathways such as faults or fractures.

As methane solubility is strongly depth dependent (Figure S3), dissolutive retention is likely to be even more significant when gas migration occurs at greater depths than those considered in this study. However, the effect of increasing solubility due to increasing pressures may be counteracted somewhat by increasing salinities, which decrease methane solubility. Also, groundwater is generally more stagnant at depth than in surficial aquifers. As shown in this work, dissolutive is limited in the absence of groundwater flow. The complex interaction of these processes, and their effect on the fate of gas migration occurring at depths greater than those considered in this study (up to $480 \mathrm{mbgl}$ ), would be a relevant subject for further research. 


\subsubsection{Gaseous pooling and permeability clay layers to gas migration}

While significant gas phase pooling occurred below the low permeable clay layers ( $k_{v}$ up to minimum of $4 \cdot 10^{-15} \mathrm{~m}^{2}, P_{e}$ up to $7.8 \mathrm{kPa}$ ) in the $2^{\text {nd }}$ case study, they were ultimately permeable to the migrating gas (Figure 7). Invasion of a higher entry pressure layer requires a large enough gas accumulation in the underlying layer such that the combined capillary and gravitational forces exceed the entry pressure barrier. For large enough entry pressure values and horizontal barriers, such conditions would not be obtained as the accumulating gas pool spreads out laterally into a thin, pancake like shape. High resolution permeability measurements have shown that thin, low permeability clay lenses can be present within larger clayey formations, with permeabilities that are orders of magnitude lower than the average permeability of the unit (Rogiers et al., 2014). Given their low permeability and presumably higher entry pressure, these lenses would likely act as impermeable barriers to gas phase flow, essentially turning the entire formation into a cap rock. However, the ubiquity and lateral extent of these lenses is poorly understood. Therefore, further research into how heterogeneity of clay deposits impacts gas migration would be required.

\subsection{4 | Continuum modelling of gas migration}

The low observed saturations call into question whether the injected gas actually forms a continuous phase, and hence whether the widely-used Darcy's law approach is applicable for modelling gas migration through unconsolidated aquifers. Air sparging experiments have shown that, for unconsolidated sediments, the injected gas phase migrates as continuous gaseous channels when grain sizes are $\leq 1 \mathrm{~mm}$. For larger grain sizes the flow pattern gradually changes to discontinuous bubble flow (Brooks et al., 1999). The grain sizes considered in this study fall in the former category, and hence channel flow may be expected to dominate, although the flow type is also dependent on the flux size. Furthermore, whether such migration takes the form of a dendritic network of small channels or a smaller amount of larger gas channels is poorly understood (Brooks et al., 1999). Continuous dewatered channels through which the gas phase dominantly migrates also occurred in the field experiments of gas migration by Cahill et al. (2018). Observed dissolved methane concentrations below theoretical solubility were attributed to this flow pattern, as the available contact area over which mass transfer between phases can occur is smaller, and the collected groundwater samples aggregate both water that has been in contact with a gas channel and water that has not.

As this process is not captured in our simulations, the resulting amount of dissolution may be overestimated. On the other hand, mechanical dispersion was not included in our simulations. Excluding dispersion actually leads to an underestimation of the dissolutive capacity, as dispersion would spread out both the gas phase and the dissolved methane more rapidly, allowing for more contact with the water and quicker transport of dissolved methane away from the gas phase plume. Ultimately, the suitability of continuum models for modelling gas migration should be further analyzed through reproduction of experimental results. A promising experimental method which could be employed for this purpose was 
recently published by Ven and Mumford (2018), who injected gaseous $\mathrm{CO}_{2}$ at the bottom of a $2 \mathrm{D}$ flow cell and used $\mathrm{pH}$ as a proxy to visually track dissolved $\mathrm{CO}_{2}$ concentrations. Reproducing such experiments with numerical simulation would be a good model validation strategy.

\subsection{5 | Implications for methane monitoring}

From this study a number of important implications for monitoring of gas migration and leakages in the vicinity of oil and gas wells can be derived. Notably, surficial expressions of gas leakage originating at depth in unconsolidated sedimentary basins may take several years to manifest in settings dominated by relatively coarse grained sands, and may take at least up to several decades when migrating gas also encounters interbedded low permeable layers. Surficial detection of leaking oil and gas wellbores may therefore only become possible long after the onset of leakage, and potentially after wells have already been abandoned. This is particularly relevant as in many oil and gas jurisdictions decommissioned wells are cut and buried below the ground surface (Davies et al., 2014; Schout et al., 2019), in which case direct measurements of well integrity failure at the wellhead are no longer possible. Furthermore, for example in the Netherlands there are currently no regulations in place that require operators to monitor the locations of gas wells for extensive periods post-decommissioning.

Relying on surficial flux measurements or near-surface groundwater wells may lead to the underestimation of the actual occurrence and magnitude of gas leakage, and groundwater contamination at depth may remain unnoticed. Hence, measuring dissolved gas molecular and isotopic compositions in groundwater wells in close proximity to potential leakage points is likely a more reliable method. When surface expressions do occur, the dissolution of methane may still be such that measured fluxes at the surface only represent a fraction of the flow rate at the leakage point. Lastly, our simulations show that regional groundwater flow may cause the center of a migrating gas plume to be transported several tens of meters downstream from the well before reaching the surface. Recent field studies have employed search radii of $15 \mathrm{~m}$ (Schout et al., 2019) and $20 \mathrm{~m}$ (Forde et al., 2019) from the coordinates of gas wells when carrying out surficial flux measurements. While likely suitable in most cases, widening the investigated area in the direction of groundwater flow may need to be considered depending on the conditions.

\section{5 | CONCLUSIONS}

Oil and gas well failure leading to gas migration in the subsurface poses both an environmental and safety hazard. Effective mitigation of these hazards and the proper assessment of their impact is reliant on the successful detection and quantification of leaks. In this study, upward methane migration through unconsolidated aquifers was analyzed using two-phase, twocomponent $\left(\mathrm{H}_{2} \mathrm{O}\right.$ and $\left.\mathrm{CH}_{4}\right)$ numerical simulations in DuMu${ }^{x}$. Results show that the retention of migrating methane due to dissolution into laterally flowing groundwater can become 
significant at groundwater Darcy velocities as low as $1 \mathrm{~m} . \mathrm{yr}^{-1}$. Retention was shown to be dependent on a complex interaction between the lateral groundwater velocity, the depth of the leak, and the velocity and shape of the upwardly migrating gas plume. The latter is in turn a function of the leakage flux and sediment properties (permeability, capillary pressuresaturation and relative permeability relations, and residual gas saturation). Across a range of conditions representative of unconsolidated aquifers and leak sizes up to $1 \mathrm{~m}^{3} \mathrm{CH}_{4}^{\text {atm }} \cdot \mathrm{d}^{-1}$, the time it took before the gas plume propagated through to the top of the modelled domain varied from less than 2 months to 5 years. In some scenarios, the total methane leakage rate was dissolved and transported laterally, causing the gas plume to stagnate at depth.

Subsurface methane retention was even more pronounced in additional simulations of migration through stratified sequences based on the hydrogeological conditions at two leaking gas wells in the Netherlands, consisting of a number of alternating sedimentary units ranging in grain size from clays to coarse sands. Under such conditions, depending on the imposed groundwater head gradient, flow rates of up to $10 \mathrm{~m}^{3} \mathrm{CH}_{4}{ }^{\text {atm }} \cdot \mathrm{d}^{-1}$ were either entirely retained in subsurface or took several decades to fully develop. Not only the presence of fine grained and low permeable layers formed barriers to upward gas migration, but also high permeable sands with large groundwater velocities. These allow for a larger dissolutive capacity, particularly when the migrating gas phase has been spread out laterally by underlying low permeability units. Overall, the results of this study show that for the most commonly observed methane leakage rates $\left(0.1-10 \mathrm{~m}^{3} \cdot \mathrm{d}^{-1}\right)$, unconsolidated aquifer systems with lateral groundwater flow can retain significant amounts of migrating methane due to dissolution. Consequently, resulting atmospheric methane emissions above such leaks may be delayed with decades after the onset of leakage, significantly reduced or prevented entirely. Therefore, groundwater contamination and future explosion hazards may go unnoticed.

\section{Acknowledgements}

This work is part of the research program 'Shale Gas and Water' with project number 859.14.001, which is financed by the Dutch Research Council (NWO). We thank the German Research Foundation (DFG) for providing financial support for a visit to Stuttgart University in March of 2019 through the SFB 1313, project number 327154368. Furthermore, we thank Dennis Gläser of Stuttgart University for extensive assistance with setting up the DuMux simulations and many helpful discussions about numerical simulation of multiphase flow and transport in general. 


\section{REFERENCES}

Ackermann, S., Beck, M., Becker, B., Class, H., Fetzer, T., Flemisch, B., et al. (2017). DuMuX 2.11.0. https:// doi.org/10.5281/ZENODO.439488

Bloemendal, M., \& Hartog, N. (2018). Analysis of the impact of storage conditions on the thermal recovery efficiency of low-temperature ATES systems. Geothermics, 71, 306-319. https://doi. org/10.1016/j.geothermics.2017.10.009

Brooks, M. C., Wise, W. R., \& Annable, M. D. (1999). Fundamental Changes in In Situ Air Sparging Flow Patterns. Groundwater Monitoring \& Remediation, 19(2), 105-113. https://doi. org/10.1111/j.1745-6592.1999.tb00211.x

Brooks, R. H., \& Corey, A. T. (1964). Hydraulic properties of porous media. Hydrology Papers, Colorado State University. https://doi.org/10.13031/2013.40684

Brownlow, J. W., James, S. C., \& Yelderman, J. C. (2016). Influence of Hydraulic Fracturing on Overlying Aquifers in the Presence of Leaky Abandoned Wells. Groundwater, 54(6), 781-792. https://doi. org/10.1111/gwat.12431

Cahill, A. G., Steelman, C. M., Forde, O., Kuloyo, O., Emil Ruff, S., Mayer, B., et al. (2017). Mobility and persistence of methane in groundwater in a controlled-release field experiment. Nature Geoscience. https://doi.org/10.1038/ngeo2919

Cahill, A. G., Parker, B. L., Mayer, B., Mayer, K. U., \& Cherry, J. A. (2018). High resolution spatial and temporal evolution of dissolved gases in groundwater during a controlled natural gas release experiment. Science of the Total Environment, 622-623, 1178-1192. https://doi.org/10.1016/j. scitotenv.2017.12.049

Cahill, A. G., Beckie, R., Ladd, B., Sandl, E., Goetz, M., Chao, J., et al. (2019). Advancing knowledge of gas migration and fugitive gas from energy wells in northeast British Columbia, Canada. Greenhouse Gases: Science and Technology, 18(2019), 1-18. https://doi.org/10.1002/ghg.1856

Chilingar, G. V., \& Endres, B. (2005). Environmental hazards posed by the Los Angeles Basin urban oilfields: An historical perspective of lessons learned. Environmental Geology. https://doi. org/10.1007/s00254-004-1159-0

Cirkel, G., Hartog, N., De La, B., Gonzalez, L., \& Stuyfzand, P. (2015). Methaan in ondiep Nederlands grondwater: verbinding met de diepe ondergrond? H2O. Retrieved from https://goo.gl/7GCtkS

Clayton, W. S. (1999). Effects of pore scale dead-end air fingers on relative permeabilities for air sparging in soils. Water Resources Research, 35(10), 2909-2919. https://doi.org/10.1029/1999WR900202

D'Aniello, A., Fabbricino, M., Ducci, D., \& Pianese, D. (2019). Numerical Investigation of a Methane Leakage from a Geothermal Well into a Shallow Aquifer. Groundwater, (September). https://doi. org/10.1111/gwat.12943

Davies, R. J., Almond, S., Ward, R. S., Jackson, R. B., Adams, C., Worrall, F., et al. (2014). Oil and gas wells and their integrity: Implications for shale and unconventional resource exploitation. Marine and Petroleum Geology, 56, 239-254. https://doi.org/10.1016/j.marpetgeo.2014.03.001

Dusseault, M. B., Jackson, R. E., \& MacDonald, D. (2014). Towards a Road Map for Mitigating the Rates and Occurrences of Long-Term Wellbore Leakage. Geofirma, 1-69. Retrieved from http://geofirma. com/wp-content/uploads/2015/05/lwp-final-report_compressed.pdf

Erno, B., \& Schmitz, R. (1996). Measurements of Soil Gas Migration Around Oil And Gas Wells In the Lloydminster Area. Journal of Canadian Petroleum Technology, 35(7), 37-46. https://doi. org/10.2118/96-07-05 
Fernández-Prini, R., Alvarez, J. L., \& Harvey, A. H. (2003). Henry's constants and vapor-liquid distribution constants for gaseous solutes in $\mathrm{H} 2 \mathrm{O}$ and D2O at high temperatures. Journal of Physical and Chemical Reference Data, 32(2), 903-916. https://doi.org/10.1063/1.1564818

Flemisch, B., Darcis, M., Erbertseder, K., Faigle, B., Lauser, A., Mosthaf, K., et al. (2011). DuMux: DUNE for multi-\{phase,component,scale,physics,...\} flow and transport in porous media. Advances in Water Resources, 34(9), 1102-1112. https://doi.org/10.1016/j.advwatres.2011.03.007

Forde, O. N., Mayer, K. U., \& Hunkeler, D. (2019). Identification, spatial extent and distribution of fugitive gas migration on the well pad scale. Science of The Total Environment, 652, 356-366. https://doi. org/10.1016/j.scitotenv.2018.10.217

Fuller, E. N., Schettler, P. D., \& Giddings, J. C. (1966). A new method for prediction of binary gasphase diffusion coefficients. Industrial and Engineering Chemistry, 58(5), 18-27. https://doi. org/10.1021/ie50677a007

Gasda, S. E., Bachu, S., \& Celia, M. A. (2004). Spatial characterization of the location of potentially leaky wells penetrating a deep saline aquifer in a mature sedimentary basin. Environmental Geology, 46(6-7), 707-720. https://doi.org/10.1007/s00254-004-1073-5

Helmig, R. (1997). Multiphase flow and transport processes in the subsurface. A contribution to the modeling of hydrosystems. Environmental Engineering. Springer. Retrieved from https://www. springer.com/gp/book/9783642645457

Kang, M., Kanno, C. M., Reid, M. C., Zhang, X., Mauzerall, D. L., Celia, M. A., et al. (2014). Direct measurements of methane emissions from abandoned oil and gas wells in Pennsylvania. Proceedings of the National Academy of Sciences, 111(51), 18173-18177. https://doi.org/10.1073/pnas.1408315111

Kang, M., Christian, S., Celia, M. A., Mauzerall, D. L., Bill, M., Miller, A. R., et al. (2016). Identification and characterization of high methane-emitting abandoned oil and gas wells. Proceedings of the National Academy of Sciences, 113(48), 13636-13641. https://doi.org/10.1073/pnas.1605913113

King, G. E., \& King, D. E. (2013). Environmental Risk Arising From Well-Construction Failure--Differences Between Barrier and Well Failure, and Estimates of Failure Frequency Across Common Well Types, Locations, and Well Age. SPE Production \& Operations, 28(04), 323-344. https://doi. org/10.2118/166142-PA

Kissinger, A., Helmig, R., Ebigbo, A., Class, H., Lange, T., Sauter, M., et al. (2013). Hydraulic fracturing in unconventional gas reservoirs: Risks in the geological system, part 2: Modelling the transport of fracturing fluids, brine and methane. Environmental Earth Sciences, 70(8), 3855-3873. https:// doi.org/10.1007/s12665-013-2578-6

Klazinga, D. R., Steelman, C. M., Cahill, A. G., Walton, K. M., Endres, A. L., \& Parker, B. L. (2019). Methane gas transport in unconfined aquifers: A numerical sensitivity study of a controlled release experiment at CFB Borden. Journal of Contaminant Hydrology, 225, 103506. https://doi. org/10.1016/j.jconhyd.2019.103506

Kombrink, H., Doornebal, J. C., Duin, E. J. T., Den Dulk, M., Van Gessel, S. F., Ten Veen, J. H., \& Witmans, N. (2012). New insights into the geological structure of the Netherlands: results of a detailed mapping project. Netherlands Journal of Geosciences/ Geologie En Mijnbouw, 91(4), 419-446. https://doi.org/10.1017/S0016774600000329

Kopp, A. (2009). Evaluation of CO2 Injection Processes in Geological Formations for Site Screening. Stuttgart University.

Lackey, G., \& Rajaram, H. (2018). Modeling gas migration, sustained casing pressure, and surfacecasing-vent flow in onshore oil and gas wells. Water Resources Research, 1-26. https://doi. org/10.1029/2018WR024066 
McMahon, P. B., Thomas, J. C., Crawford, J. T., Dornblaser, M. M., \& Hunt, A. G. (2018). Methane in groundwater from a leaking gas well, Piceance Basin, Colorado, USA. Science of the Total Environment, 634, 791-801. https://doi.org/10.1016/j.scitotenv.2018.03.371

Moortgat, J., Schwartz, F. W., \& Darrah, T. H. (2018). Numerical Modeling of Methane Leakage from a Faulty Natural Gas Well into Fractured Tight Formations. Groundwater, 56(2), 163-175. https:// doi.org/10.1111/gwat.12630

Nowamooz, A., Lemieux, J. M., Molson, J., \& Therrien, R. (2015). Numerical investigation of methane and formation fluid leakage along the casing of a decommissioned shale gas well. Water Resources Research, 51(6), 4592-4622. https://doi.org/10.1002/2014WR016146

Reagan, M. T., Moridis, G. J., Keen, N. D., \& Johnson, J. N. (2015). Numerical simulation of the environmental impact of hydraulic fracturing of tight/shale gas reservoirs on near-surface groundwater: Background, base cases, shallow reservoirs, short-term gas, and water transport. Water Resources Research, 51(4), 2543-2573. https://doi.org/10.1002/2014WR016086

Reid, R., Prausnitz, J., \& Poling, B. (1987). The Properties of Gases and Liquids (Fourth Edi). New York: McGraw-Hill.

Rice, A. K., McCray, J. E., \& Singha, K. (2018). Methane Leakage From Hydrocarbon Wellbores into Overlying Groundwater: Numerical Investigation of the Multiphase Flow Processes Governing Migration. Water Resources Research. https://doi.org/10.1002/2017WR021365

Rogiers, B., Winters, P., Huysmans, M., Beerten, K., Mallants, D., Gedeon, M., et al. (2014). Highresolution saturated hydraulic conductivity logging of borehole cores using air permeability measurements. Hydrogeology Journal, 22(6), 1345-1358. https://doi.org/10.1007/s10040-0141144-y

Roy, N., Molson, J., Lemieux, J. M., Van Stempvoort, D., \& Nowamooz, A. (2016). Three-dimensional numerical simulations of methane gas migration from decommissioned hydrocarbon production wells into shallow aquifers. Water Resources Research, 52(7), 5598-5618. https://doi. org/10.1002/2016WR018686

Schout, G., Hartog, N., Hassanizadeh, S. M., \& Griffioen, J. (2018). Impact of an historic underground gas well blowout on the current methane chemistry in a shallow groundwater system. Proceedings of the National Academy of Sciences, 115(2), 296-301. https://doi.org/10.1073/pnas.1711472115

Schout, G., Griffioen, J., Hassanizadeh, S. M., Cardon de Lichtbuer, G., \& Hartog, N. (2019). Occurrence and fate of methane leakage from cut and buried abandoned gas wells in the Netherlands. Science of The Total Environment, 659, 773-782. https://doi.org/10.1016/j.scitotenv.2018.12.339

Schwartz, M. O. (2015). Modelling the hypothetical methane-leakage in a shale-gas project and the impact on groundwater quality. Environmental Earth Sciences, 73(8), 4619-4632. https://doi. org/10.1007/s12665-014-3787-3

SodM. (2019). De integriteit van onshore putten in Nederland. Den Haag. Retrieved from https://www. sodm.nl/documenten/rapporten/2019/02/07/de-integriteit-van-onshore-putten-in-nederland

Van Stempvoort, D., Maathuis, H., Jaworski, E., Mayer, B., \& Rich, K. (2005). Oxidation of fugitive methane in ground water linked to bacterial sulfate reduction. Ground Water, 43(2), 187-199. https://doi. org/10.1111/j.1745-6584.2005.0005.x

Tatomir, A., Mcdermott, C., Bensabat, J., Class, H., Edlmann, K., Taherdangkoo, R., \& Sauter, M. (2018). Conceptual model development using a generic Features, Events, and Processes (FEP) database for assessing the potential impact of hydraulic fracturing on groundwater aquifers. Advances in Geosciences, 45, 185-192. https://doi.org/10.5194/adgeo-45-185-2018 
Townsend-Small, A., Ferrara, T. W., Lyon, D. R., Fries, A. E., \& Lamb, B. K. (2016). Emissions of coalbed and natural gas methane from abandoned oil and gas wells in the United States. Geophysical Research Letters, 43(5), 2283-2290. https://doi.org/10.1002/2015GL067623

Ven, C. J. C. Van De, \& Mumford, K. G. (2018). Visualization of gas dissolution following upward gas migration in porous media: technique and implications for stray gas. Advances in Water Resources, 115, 33-43. https://doi.org/10.1016/j.advwatres.2018.02.015

Vengosh, A., Jackson, R. B., Warner, N., Darrah, T. H., \& Kondash, A. (2014). A Critical Review of the Risks to Water Resources from Unconventional Shale Gas Development and Hydraulic Fracturing in the United States. Environmental Science \& Technology, 48(15), 8334-8348. https://doi.org/10.1021/ es405118y

Vernes, R. W., \& van Doorn, T. H. . (2005). Van Gidslaag naar Hydrogeologische Eenheid; Toelichting op de totstandkoming van de dataset REGIS II. NITG-05-038-B. Utrecht: TNO.

Verweij, J. M., Nelskamp, S. N., Ten Veen, J. H., De Bruin, G., Geel, K., \& Donders, T. H. (2018). Generation, migration, entrapment and leakage of microbial gas in the Dutch part of the Southern North Sea Delta. Marine and Petroleum Geology, 97(July), 493-516. https://doi.org/10.1016/j. marpetgeo.2018.07.034

de Vries, J. J. (2007). Groundwater. In T. E. Wong, D. A. J. Batjes, \& J. de Jager (Eds.), Geology of the Netherlands (p. 354). Amsterdam: Royal Netherlands Academy of Arts and Sciences. Retrieved from https://www.press.uchicago.edu/ucp/books/book/distributed/G/bo5456650.html

Wagner, W., \& Pruss, A. (2002). The IAPWS formulation 1995 for the thermodynamic properties of ordinary water substance for general and scientific use. Journal of Physical and Chemical Reference Data, 31(2), 387-535. https://doi.org/10.1063/1.1461829

Wentworth, C. K. (1922). A Scale of Grade and Class Terms for Clastic Sediments Author ( $\mathrm{s}$ ): Chester K . Wentworth Published by : The University of Chicago Press Stable URL : http://www.jstor.org/ stable/30063207. The Journal of Geology, 30(5), 377-392. https://doi.org/10.1086/622910

Wisen, J., Chesnaux, R., Werring, J., Wendling, G., Baudron, P., \& Barbecot, F. (2019). A portrait of wellbore leakage in northeastern British. Proceedings of the National Academy of Sciences of the United States of America, 1-10. https://doi.org/10.1073/pnas.1817929116

Woda, J., Wen, T., Oakley, D., Yoxtheimer, D., Engelder, T., Castro, M. C., \& Brantley, S. L. (2018). Detecting and explaining why aquifers occasionally become degraded near hydraulically fractured shale gas wells. Proceedings of the National Academy of Sciences. https://doi.org/10.1073/ pnas. 1809013115

Wolfe, A. L., \& Wilkin, R. T. (2017). Evidence of Sulfate-Dependent Anaerobic Methane Oxidation within an Area Impacted by Coalbed Methane-Related Gas Migration. Environmental Science and Technology, 51(3), 1901-1909. https://doi.org/10.1021/acs.est.6b03709 


\section{APPENDIX}
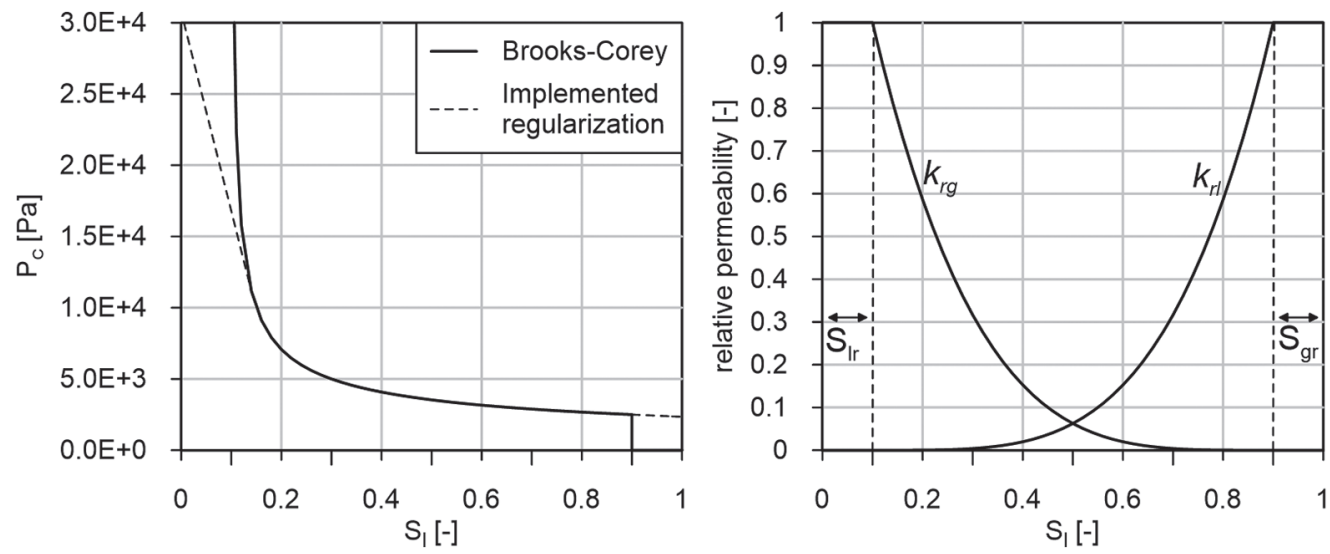

Figure S1 | Example Brooks-Corey capillary pressure saturation (left) and relative permeability diagrams (right) according to formulations in section 2.1, with $\mathrm{P}_{\mathrm{e}}=2500[\mathrm{~Pa}], \lambda=2[-]$ and $\mathrm{S}_{\mathrm{rl}}$ and $\mathrm{S}_{\mathrm{rg}}=0.1$ [-]. For illustrative purposes, the threshold $\mathrm{S}_{\mathrm{e}}$ value for the regularization of the $\operatorname{Pc}\left(\mathrm{S}_{1}\right)$ relationship at low wetting saturations was set to 0.05 . However, 0.01 is used in all simulations in this paper.

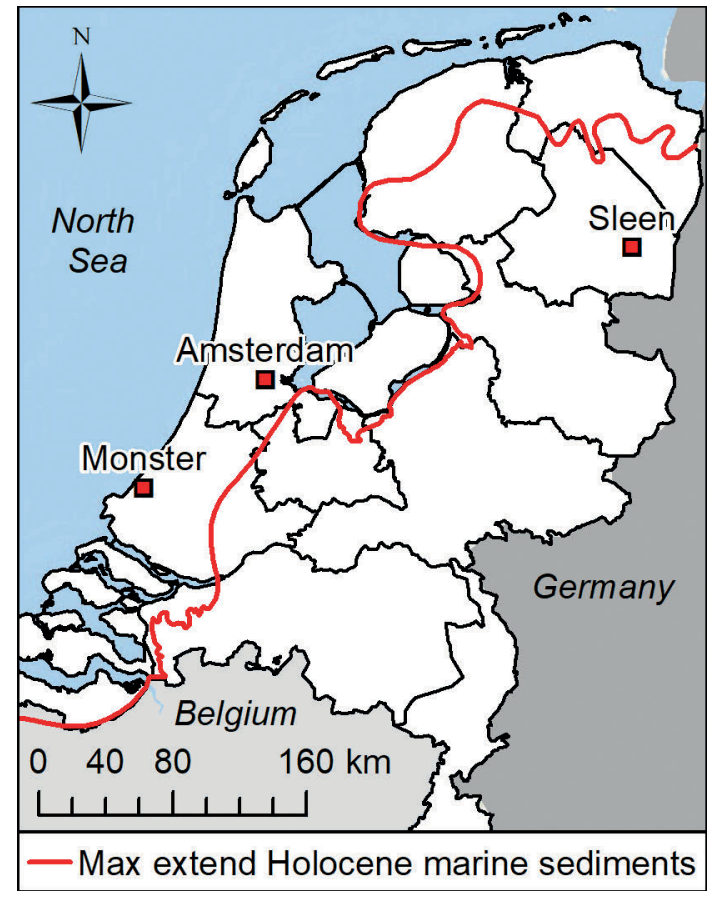

Figure S2 | Map of the Netherlands, where the red line (based on Griffioen et al., 2013) separates the coastal Holocene (north-western) and non-Holocene (southeastern) parts of the country. Also shown are the locations of the two case studies.

Griffioen, J., Vermooten, S., Janssen, G., 2013. Geochemical and palaeohydrological controls on the composition of shallow groundwater in the Netherlands. Appl. Geochemistry 39, 129-149. https://doi. org/10.1016/j.apgeo-chem.2013.10.005 


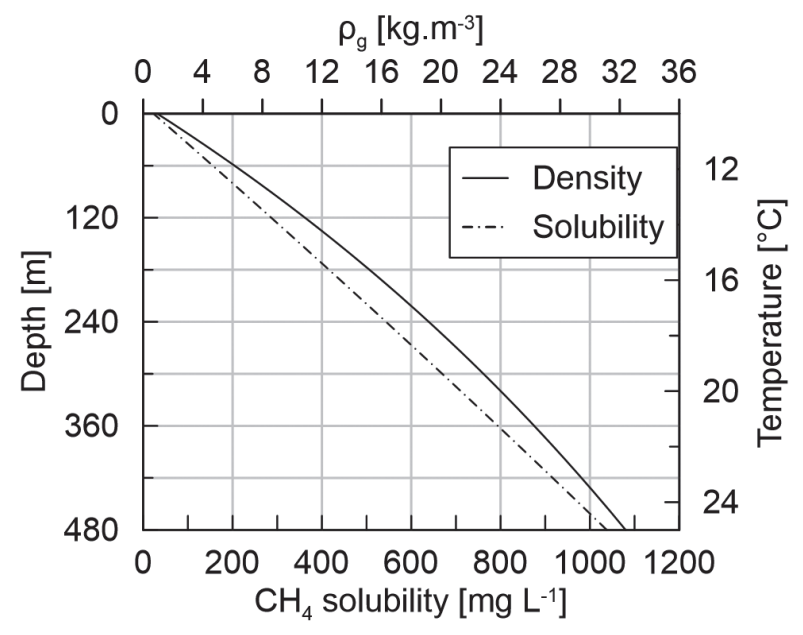

Figure S3 | Methane solubility and gas phase density within the range of temperature and pressure included in our simulations. Temperature is based on a thermal gradient of $31.3^{\circ} \mathrm{C} \mathrm{km}^{-1}$. At atmospheric pressure and at $10^{\circ} \mathrm{C}$, methane solubility and density are $31.4 \mathrm{mg} \cdot \mathrm{L}^{-1}$ and $0.69 \mathrm{~kg} \cdot \mathrm{m}^{-3}$, respectively.

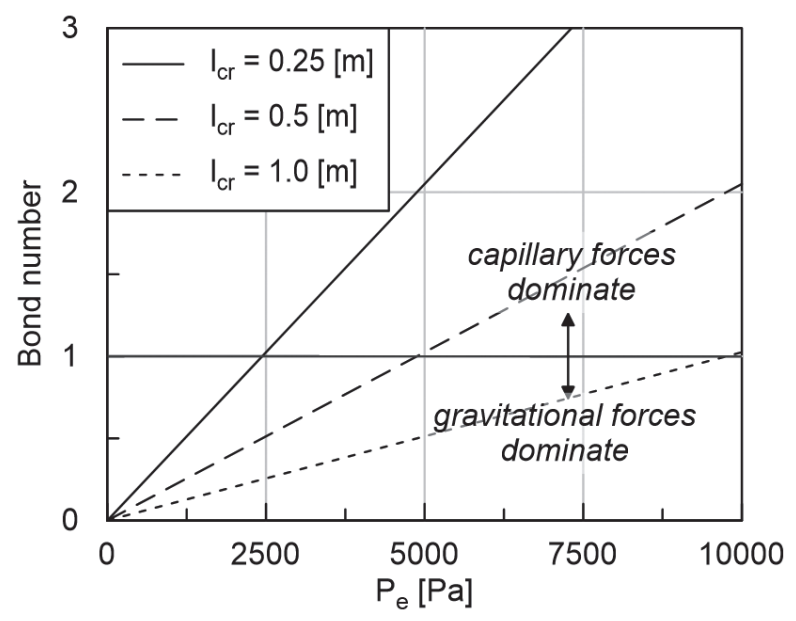

Figure S4 | The dimensionless Bond number (eq. 8) as a function of capillary entry pressure (critical pressure), shown for three possible values of the critical length $\left(I_{c r}\right)$. 
Table S1 | Reference values used for Leverett scaling of entry pressure values using the permeability values obtained from the REGIS II model. Resulting values that were implemented in the simulations of the stratified models shown in Figure 3.

\begin{tabular}{lccc}
\hline & sand & complex & clay \\
\hline $\mathrm{P}_{\mathrm{e}}[\mathrm{Pa}]$ & 1500 & 3000 & 5000 \\
\hline $\mathrm{k}_{\mathrm{h}}\left[\mathrm{m}^{2}\right]$ & $1.00 \mathrm{E}-11$ & $5.00 \mathrm{E}-12$ & $1.00 \mathrm{E}-13$ \\
\hline$\Phi[-]$ & 0.3 & 0.35 & 0.4 \\
\hline
\end{tabular}

Table S2 | Percentage of inflowing methane that exits through the top boundary of the model $\left(Q_{\text {out }} / Q_{\text {in }}\right)$ with increasing time, for the two simulated case studies each under two different head gradients.

\begin{tabular}{|c|c|c|c|c|c|c|c|c|c|c|c|c|}
\hline \multirow{2}{*}{$\begin{array}{l}\text { Case } \\
\text { study [\#] }\end{array}$} & \multirow{2}{*}{$\begin{array}{c}\mathrm{dH} / \mathrm{dx} \\
{\left[\mathrm{m} \cdot \mathrm{km}^{-1}\right]}\end{array}$} & \multirow{2}{*}{$\begin{array}{c}\text { time to } \\
\text { top aquifer } \\
\text { [yrs] }\end{array}$} & \multicolumn{10}{|c|}{$Q_{\text {out }} / Q_{\text {in }}[\%]$} \\
\hline & & & $\begin{array}{c}5 \\
\text { [yrs] }\end{array}$ & $\begin{array}{c}7.5 \\
\text { [yrs] }\end{array}$ & $\begin{array}{c}10 \\
\text { [yrs] }\end{array}$ & $\begin{array}{l}12.5 \\
\text { [yrs] }\end{array}$ & $\begin{array}{c}15 \\
\text { [yrs] }\end{array}$ & $\begin{array}{c}20 \\
{[y r s]}\end{array}$ & $\begin{array}{c}25 \\
\text { [yrs] }\end{array}$ & $\begin{array}{c}30 \\
{[y r s]}\end{array}$ & $\begin{array}{c}40 \\
\text { [yrs] }\end{array}$ & $\begin{array}{c}50 \\
{[y r s]}\end{array}$ \\
\hline 1 (Sleen) & 0.25 & 5.1 & 0.0 & 24.9 & 33.9 & 37.5 & 39.1 & 40.5 & 41.0 & 41.2 & 41.4 & 41.4 \\
\hline 2 (Sleen) & 1 & not reached & 0.0 & 0.0 & 0.0 & 0.0 & 0.0 & 0.0 & 0.0 & 0.0 & 0.0 & 0.0 \\
\hline 3 (Monster) & 0.25 & 16.2 & 0.0 & 0.0 & 0.0 & 0.0 & 0.0 & 19.2 & 31.6 & 38.0 & 43.9 & 46.3 \\
\hline 4 (Monster) & 1 & not reached & 0.0 & 0.0 & 0.0 & 0.0 & 0.0 & 0.0 & 0.0 & 0.0 & 0.0 & 0.0 \\
\hline
\end{tabular}




\section{CHAPTER}

Synthesis 


\section{1 | INTRODUCTION}

The research presented in this thesis is a contribution to the body of knowledge about the origin, fate and detection of methane leakage. Methane leakage resulting from oil and gas production presents a risk to groundwater quality, may contribute to greenhouse gas emissions, and poses an explosion hazard when allowed to accumulate in confined spaces. Furthermore, the conduits for fluid migration from the deep subsurface that are signalled by methane leakage could serve as pathways for migration of more hazardous fluids. The research questions that are answered in this thesis were inspired by the situation in the Netherlands, where, in spite of being one of the main gas producing countries in Europe, almost no research had been done to investigate the prevalence of anthropogenic methane leakage caused by gas production, nor to assess its environmental impact and safety hazard. In this work, it was shown that Dutch gas wells that are plugged, cut and buried can indeed leak (chapter 3). Evidence for anthropogenically caused methane leakage from the deep subsurface was also found at the location of a gas well blowout that occurred in 1965 (chapter 4). On the other hand, no evidence for methane leakage through natural connections with the deep subsurface was found (chapter 2). The fate and subsequent detection of methane were shown to be impacted by mixing with the naturally occurring biogenic methane in shallow aquifers (chapter 2), oxidation and dispersion of methane in the vadose zone (chapter 3), dispersion and anaerobic oxidation in groundwater (chapter 4) and dissolution into laterally flowing groundwater during upward migration of methane gas (chapter 5).

First, a summary of the main findings in chapters $2-5$ will be described. Then, a synthesis of the results relating to the origin of methane in the Dutch groundwater and the occurrence of methane leakage from the deep subsurface will be given. This section also additionally includes a first assessment of potential atmospheric methane emissions from groundwater pumping in the Netherlands. A synthesis of the results relating to fate and detection of methane leakage is then presented, including a discussion of the implications of this research for gas leakage from other non-hydrocarbon geo-energy applications, such as storage of $\mathrm{H}_{2}$ or $\mathrm{CO}_{2}$. This section is concluded with a number of recommendations for monitoring of methane leakage in practice. Finally, concluding remarks are given about the implications of this work to the aforementioned risks of methane leakage.

\section{2 | SUMMARY OF MAIN FINDINGS}

The origin and distribution of methane in the subsurface of the Netherlands was assessed in chapter 2. Methane is ubiquitous in the shallow Quaternary groundwater system, with concentrations in $7.5 \%$ of samples exceeding $10 \mathrm{mg} \cdot \mathrm{L}^{-1}$ and median concentrations of $0.2 \mathrm{mg} \cdot \mathrm{L}^{-1}$. The largest methane concentrations occur in the coastal lowlands, where Holocene peats and marine clays overly the Pleistocene aquifers (except at the coastal dunes). There, median concentrations peak at $4.0 \mathrm{mg} \cdot \mathrm{L}^{-1}$ between 20 to $40 \mathrm{~m}$ bgs. However, at greater 
depths ( 100 - 160 m bgs) median methane concentrations are lower here than in the rest of the country, most likely because of the presence of dissolved sulphate of seawater origin preventing microbial methanogenesis at these depths. Besides these surficial Holocene formations, other prominent sources of dissolved methane in Dutch shallow groundwater were shown to be the marine Eem Formation and the glacial Peelo Formation.

Methane in groundwater samples collected at locations where migration of thermogenic gas from the deep subsurface was deemed most likely (i.e. close to major faults and overlying gas reservoirs) was of biogenic origin. Hence, there was no evidence for natural migration of thermogenic methane from the deep subsurface towards shallow groundwater. At greater depths, below the Neogene and Paleogene marine clays that form the hydrogeological base in the country, dissolved methane had either a mixed biogenic/ thermogenic (in groundwater wells with depths up to $871 \mathrm{~m} \mathrm{bgs}$ ) or an oil associated isotopic signature (in geothermal wells ranging in depth from 1640 - 2625 mbgs). Overall, the study therefore shows that future observations of thermogenic methane in Dutch shallow groundwater are most likely attributable to migration through anthropogenic rather than natural conduits.

The occurrence of methane leakage from 29 cut and buried abandoned oil and gas wells was assessed in chapter 3, using soil gas flux measurements carried out at depth. Leakage was observed at one gas well (MON-02), constituting the first observation of well integrity failure resulting in gas leakage at a fully decommissioned gas well in the Netherlands. Neither surficial methane concentration scanning nor the static flux measurements carried out at the surface were able to detect the leaking gas. These findings support the need for subsurface measur ements when trying to detect and quantify methane leakage from cut and buried gas wells, and have important implications for past and future studies aimed at detecting methane leakage at such wells. In spite of considerable uncertainty, results show that leakages from gas wells are unlikely to contribute significantly to GHG emissions in the Netherlands. Possible negative impacts on groundwater quality do need to be considered. Furthermore, the potential explosion hazards caused by methane leakage from cut and buried abandoned wells should be taken into account when planning construction projects.

In chapter 4 the long term impact of methane leakage on a shallow groundwater system was assessed at the location of a catastrophic gas well blowout that occurred in 1965 . The results showed that in water wells close to the location of the blowout dissolved methane is still present in highly elevated concentrations. Since this methane has a thermogenic isotopic signature that closely resembles that of the underlying gas reservoir, most likely, the long-term persistence of elevated methane concentrations is the result of continuing gas leakage from the reservoir initiated by the blowout. Anaerobic oxidation of methane, coupled to the reduction of iron and manganese oxides, plays a major role in the natural attenuation of the dissolved methane plume. However, the oxidation capacity is limited by the availability of iron and manganese oxides in the aquifer sediments, which is resulting in a slowly protruding methane plume. As dissolved thermogenic methane was only observed up to around $500 \mathrm{~m}$ from the location of blowout, the study highlighted that monitoring 
for gas contamination should be conducted in the closest proximity possible to potential leakage sources. In addition, the compositional and isotopic impact of oxidation may lead to erroneous assessment of the origin of dissolved gases, especially when $\delta^{13} \mathrm{C}$ is analysed without $\delta D$.

Lastly, in chapter 5, upward migration of methane gas through unconsolidated aquifers was analysed using two-phase, two-component $\left(\mathrm{H}_{2} \mathrm{O}\right.$ and $\left.\mathrm{CH}_{4}\right)$ numerical simulations in $\mathrm{DuMu}^{\mathrm{x}}$. Results show that the retention of migrating methane due to dissolution into laterally flowing groundwater can become significant even at low groundwater Darcy velocities of just $1 \mathrm{~m} . \mathrm{yr}^{-1}$. This is particularly true for simulations of migration through horizontally layered stratigraphic sequences consisting of a number of alternating sedimentary units ranging from clays to sands. Under such conditions, depending on the imposed groundwater head gradient, imposed fluxes at the leakage point of up to $10 \mathrm{~m}^{3} \mathrm{CH}_{4}{ }^{\text {atm }} \cdot \mathrm{d}^{-1}$ are entirely retained in the subsurface or can take several decades to fully develop. The simulations highlight that not only the presence of fine grained and low permeable layers may form barriers to upward gas migration, but also high permeable sands with relatively high groundwater flow velocities, as this creates a larger dissolutive retention capacity. This study therefore showed that - in addition to trapping, dispersion and oxidation - dissolution may lead to actual wellbore leakage rates being underestimated, particularly when measuring surface expressions of gas migration.

\section{3 | ORIGIN AND DISTRIBUTION OF GROUNDWATER METHANE IN THE NETHERLANDS}

Methane in the shallow Plio-Pleistocene groundwater system of the Netherlands was shown to be of biogenic origin, with the exception of specific locations where anthropogenic activities had caused methane leakage from the deep subsurface to occur. Evidence for natural migration of thermogenic methane to these layers was not encountered, although this does not exclude the possibility of such migration occurring at hitherto uninvestigated locations. Very low concentrations of thermogenic methane $\left(<0.1 \mathrm{mg} \cdot \mathrm{L}^{-1}\right)$ were observed in deeper Paleogene and older formations. However, these observations were made at large offset distance both horizontally and vertically from known conventional gas accumulations. Given that temperatures at the sampling depths were not sufficient for thermocatalytic generation of methane, the exact migration mechanism remains unclear and warrants further investigation. Biogenic methane formation is controlled by redox conditions (it only forms when other electron acceptors have been depleted) and requires degradable sedimentary or dissolved organic matter to be present. Therefore, the presence of methane in groundwater does not depend solely on the properties of the host formation but is further dependent on the hydrological position in a groundwater flow path and the reactivity of the sedimentary deposits through which the groundwater has flowed. As in other studies (e.g. Molofsky et al., 2016; Zhu et al., 2017), this dependency on redox conditions is illustrated by the near mutual 
exclusivity of dissolved sulphate and methane in almost all samples, particularly those with short well screen lengths.

A source of organic matter that is abundantly present in the surficial Holocene sediments of the Dutch coastal lowlands is peat, up to depths of around $50 \mathrm{~m}$ (Doppert et al., 1975). These peat layers have long been hypothesized to be the main source of methane in Dutch groundwater (Bol, 1991). Indeed, a spatial correlation between high methane concentrations and the occurrence of peat formations was observed in this study (chapter 2). This would suggest that methanogenesis occurs in near-surface fresh groundwater, and is then subsequently transported downwards into the underlying aquifers during groundwater infiltration. However, $\delta \mathrm{D}-\mathrm{CH}_{4}$ values were nearly all higher than the $-250 \%$ o (vs. SMOW) upper limit of the fermentation pathway that is typically associated with such conditions (Milkov and Etiope, 2018). On the basis of the $\delta \mathrm{D}-\mathrm{CH}_{4}$ isotopic composition biogenic methane in the shallow aquifer systems of the Netherlands thus appears to be mainly formed through reduction of $\mathrm{CO}_{2}$. This was also found to be the dominant methanogenic process in numerous other groundwater methane baseline studies worldwide (e.g. Humez et al., 2016; Kulongoski et al., 2018; Mclntosh et al., 2014; Nicot et al., 2017) and is believed to mainly occur in marine sediments (Whiticar, 1999). The contribution of peat formations to methane in Dutch groundwater therefore seems smaller than previously believed, as was also suggested by Griffioen et al. (2013).

Significantly elevated methane concentrations were also observed in non-marine formations such as fluvial Appelscha Formation. Apparently, $\mathrm{CO}_{2}$ reduction can also be the dominant process in such formations. Besides in situ methanogenesis via $\mathrm{CO}_{2}$ reduction, an alternate explanation could be that $\mathrm{CO}_{2}$ reduction is not ongoing but took place primarily at limited burial depths, shortly after (marine) sedimentary deposition. In such conditions, turnover of organic matter is much higher than in deeper buried aquifers, and the hydrogen required for $\mathrm{CO}_{2}$ reduction would be more abundant. The presence of methane from the $\mathrm{CO}_{2}$ reduction pathway in non-marine formations could then be explained by subsequent transport away from the marine source formations. Besides advective transport of dissolved methane along with groundwater flow, such migration could also be diffusion controlled. Migration of dissolved methane over a vertical distance of more than 200 of meters was shown to be diffusion controlled for a study location in Canada (Hendry et al., 2017). Buoyancy driven gaseous migration of biogenic methane is another possibility. Methanogenesis leading to gas exsolution was observed up to depths of around $30 \mathrm{~m}$ in prior research in the Netherlands (Fortuin and Willemsen, 2005).

In spite of these uncertainties, a number of geological formations can be put forward that are most likely the main contributors to observed methane concentrations in the Netherlands (Figure 1). In the coastal lowlands, where methane concentrations in excess of $10 \mathrm{mg} / \mathrm{l}$ were most frequently observed, the Holocene marine Naaldwijk Formation and the peat-bearing Nieuwkoop Formation are prominent sources. Alternatively, methane there could locally originate from underlying Pleistocene formations. As groundwater is typically brackish to saline at the depths where those formations occur in the coastal parts 
of the country, bacterial sulphate reduction would have had to nearly exhaust the available sulphate before methanogenic bacteria could start to thrive. Similarly, early Pleistocene and Neogene marine formations are a likely source of relatively low but ubiquitous methane concentrations in areas where the initially saline groundwater has been partly replaced by infiltrating fresh groundwater. As freshwater is much lower in sulphate than seawater, relatively little sulphate reduction has to occur before methanogenesis can take place. Another main source of methane appears to be the late Pleistocene marine Eem Formation, that was deposited in the northern and western part of the Netherlands. Lastly, in the northeastern part of the country, high methane concentrations were observed in the glacial Peelo Formation. Besides this formation, extensive raised peat bogs were also present here in the past that have now been largely excavated. Methanogenesis in these peats may have also contributed to present day observed methane concentrations in groundwater.

More research is required into the importance of these different formations in controlling the observed methane concentrations, the dominant methanogenic pathways, and the timing of methanogenesis. Rather than a country wide investigation, as was carried out in this work, a follow up study on this subject would ideally be focused on a more spatially constrained study area with a high density of monitoring wells. Furthermore, in addition to the analyses carried out for this study, a number of additional parameters should be analysed, including the ${ }^{14} \mathrm{C}$ content of methane, the noble gas composition and perhaps methane clumped isotopes. Particularly in the coastal lowlands, the ${ }^{14} \mathrm{C}$ content of methane would show whether methane was produced from sediments deposited in the Holocene, the latter part of the Late Pleistocene, or older formations (e.g. Schoell, 1980). By determining the methanogenic pathway through analysis of the stable isotope composition, it should then also be possible to tell whether Holocene methane is derived mainly from the peat deposits or the marine Naaldwijk Formation. This conclusion could be further substantiated using methane clumped isotopes, as these tend to show very different values for methane formed through direct fermentation of highly reactive organic matter compared to methane formed by $\mathrm{CO}_{2}$ reduction (Stolper et al., 2018). The benefit of including noble gas composition would be that methanogenesis leading to gas exsolution leads to shifts in argon concentrations, that together with $\mathrm{N}_{2}$ content can be used to infer whether and where exsolution and dissolution of gas bubbles has occurred (Fortuin and Willemsen, 2005). 


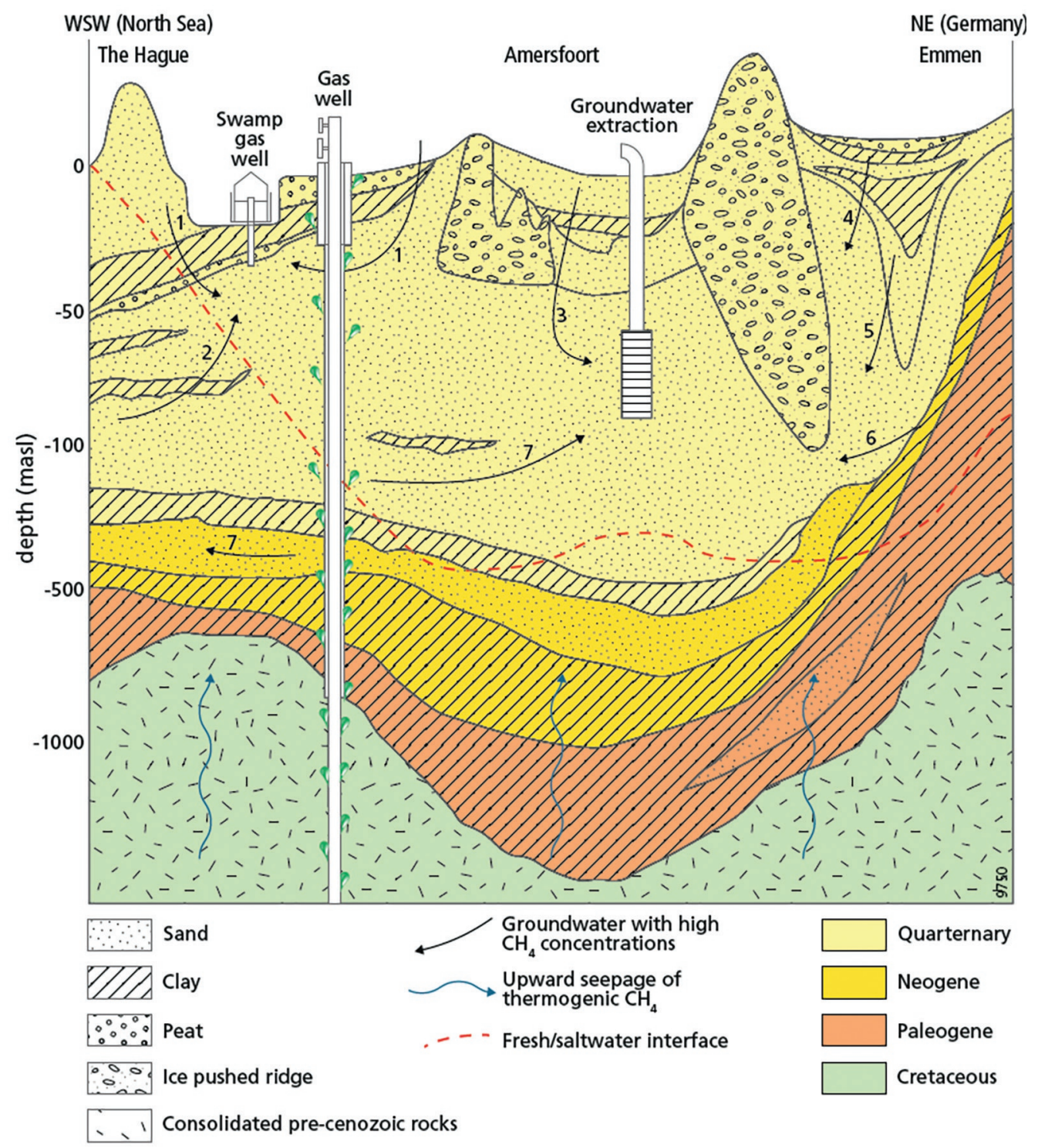

Figure 1 | Stratigraphic and lithological cross-section from the WSW (The Hague) towards the centre (Amersfoort) and NE of the country (Emmen), showing groundwater flow paths with potentially high levels of methanogenesis. (1) Groundwater infiltrating through Holocene marine and peat layers in the coastal lowlands, (2) upwelling of groundwater with methanogenesis in Pleistocene marine formations, (3) groundwater infiltrating through the late Pleistocene marine Eem Formation and subsequent flow towards a hypothetical groundwater extraction well, (4) groundwater infiltration through (now excavated) raised peats, (5) groundwater flowing through organic rich deposits of the glacial Peelo Formation and (6) methanogenesis in early Pleistocene and Neogene marine formations. Lastly, methane dissolution and subsequent transport from a hypothetical leaking gas well in the west of the country is also shown (7). Exaggerated vertical axis, and wells not drawn to scale. 
Although subject to differences in sampling bias and dataset size, methane concentrations in groundwater in the Netherlands appear to be relatively high compared to the values obtained in similar international studies (Figure 2). In this study, methane concentrations $>1 \mathrm{mg} / \mathrm{l}$ occur in $32.5 \%$ of samples, a number that is only exceeded by a study conducted in Eastern Kentucky (Zhu et al., 2017). This is evidence of the pervasive presence of dissolved methane in Dutch groundwater, that is presumably related to the equally pervasive presence of degradable organic matter in much of the Cenozoic sedimentary system that hosts freshwater circulation. Methane concentrations above solubility at $1 \mathrm{~atm}$ and $15^{\circ} \mathrm{C}(\sim 28 \mathrm{mg} / \mathrm{l})$ are not exceeded by an exceptionally large percentage of samples in the Netherlands, as 3 of 10 studies included in this comparison had a larger fraction of samples exceeding this limit. A study of methane in aquifers of the German state of Lower Saxony (Schloemer et al., 2016), which neighbours the Netherlands along the northern part of its eastern border, shows that the occurrence of elevated methane concentrations there was much lower across the entire range of concentrations levels (Figure 2). Spatially, a similar pattern is observed as in this study however, with the highest methane concentrations occurring mainly in the low lying coastal areas, and such high concentrations becoming increasingly rare with distance from the coast. As in this study, this pattern was attributed to higher organic carbon contents in this subregion, and differences in sulphate concentrations (Schloemer et al., 2016).

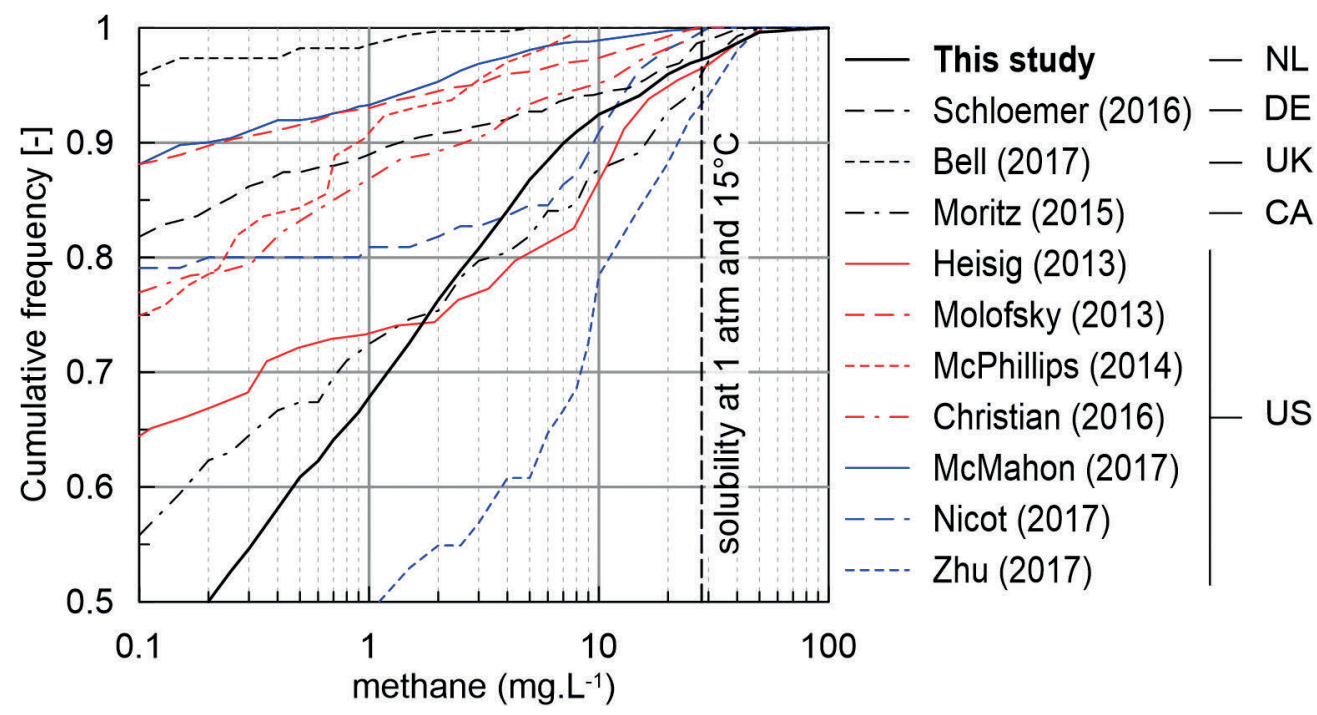

Figure 2 | Cumulative frequency distribution of dissolved methane concentrations in this study compared to that retrieved from 10 published methane concentration studies from various study areas in Germany (Schloemer et al., 2016), Great Britain (Bell et al., 2017), Canada (Moritz et al., 2015) and the USA (Christian et al., 2016; Heisig and Scott, 2013; McMahon et al., 2017; McPhillips et al., 2014; Molofsky et al., 2013; Nicot et al., 2017b; Zhu et al., 2017). 


\subsubsection{Methane emissions from groundwater pumping}

In the Netherlands, $878 \cdot 10^{6} \mathrm{~m}^{3}$ groundwater is withdrawn yearly (Vewin, 2017). The majority, $678.10^{6} \mathrm{~m}^{3}$, is extracted for drinking water purposes (Table 1). Given the relatively high methane concentrations in the country, methane emissions from groundwater extraction could be a significant and so far unconsidered source of greenhouse gas emissions. Taking the average methane concentration of $3 \mathrm{mg} \cdot \mathrm{L}^{-1}$ and assuming complete degassing occurs, $\sim 2.03 \cdot 10^{6} \mathrm{~kg} \mathrm{CH}_{4}$ would be emitted every year by the $678 \cdot 10^{6} \mathrm{~m}^{3} . \mathrm{yr}^{-1}$ withdrawn for drinking water production (Figure 1). This does not include and additional $80.10^{6} \mathrm{~m}^{3} \cdot \mathrm{yr}^{-1}$ extracted from riverbank filtration and dune infiltration water sources, which are unlikely to contain significant amounts of methane due to their young age. Groundwater withdrawals for drinking water production are $77 \%$ of total withdrawals, and the total methane emissions from groundwater withdrawals are estimated to be $2.63 \cdot 10^{6} \mathrm{~kg} \mathrm{CH}_{4} \cdot \mathrm{yr}^{-1}$. There are 187 drinking water production locations with a groundwater source in the Netherlands (Vewin, 2017). With average withdrawals of $414 \mathrm{~m}^{3} \cdot \mathrm{hr}^{-1}$ and assuming an average methane concentration of $3 \mathrm{mg}^{-1} \mathrm{~L}^{-1}$, one such location would typically result in methane emissions of $1.09 \cdot 10^{4} \mathrm{~kg} \mathrm{CH}_{4} \cdot \mathrm{yr}^{-1}$, or the equivalent of 81 cows. As shown in chapter 2 however, methane concentrations are not normally distributed. Overall methane emissions from groundwater pumping in the Netherlands are therefore dependent on the number and magnitude of withdrawals in aquifers with high methane concentrations.

Table 1 | Groundwater withdrawals in the Netherlands (Vewin, 2017).

\begin{tabular}{lc}
\hline Sector & Withdrawn volume $\left[10^{6} \mathrm{~m}^{3}\right]$ \\
\hline Drinking water* & 678 \\
\hline Agriculture, forestry, fisheries & 61 \\
\hline Industry & 134 \\
\hline Energy & 4 \\
\hline Other & 1 \\
\hline Total & $\mathbf{8 7 8}$ \\
\hline
\end{tabular}

* Not including groundwater from riverbank filtration or dune water.

In spite of uncertainty, other sources of anthropogenic methane emissions in the Netherlands are orders of magnitude larger (Environmental Data Compendium, 2017). In terms of $\mathrm{CO}_{2}$ equivalents, the estimated total emissions from groundwater extraction equal $9.4 \%$ and $0.5 \%$ of the yearly methane emitted by the energy sector and agricultural sector, respectively. Compared to total anthropogenic $\mathrm{CH}_{4}$ emissions in the Netherlands (18.9 Mton $\mathrm{CO}_{2}$ equivalents in 2015) it would be $0.3 \%$, a contribution that is similar in magnitude to the $0.2 \%$ estimated from groundwater pumping in the US (Kulongoski and McMahon, 2019). Still, at locations with high methane concentrations the produced methane could be captured 
and used for electricity generation, thereby mitigating some of the greenhouse effect by converting methane to $\mathrm{CO}_{2}$. Such a system is currently operational at one location in the Netherlands where water with methane concentrations up to $50 \mathrm{mg} \cdot \mathrm{L}^{-1}$ is extracted (Cirkel et al., 2015).

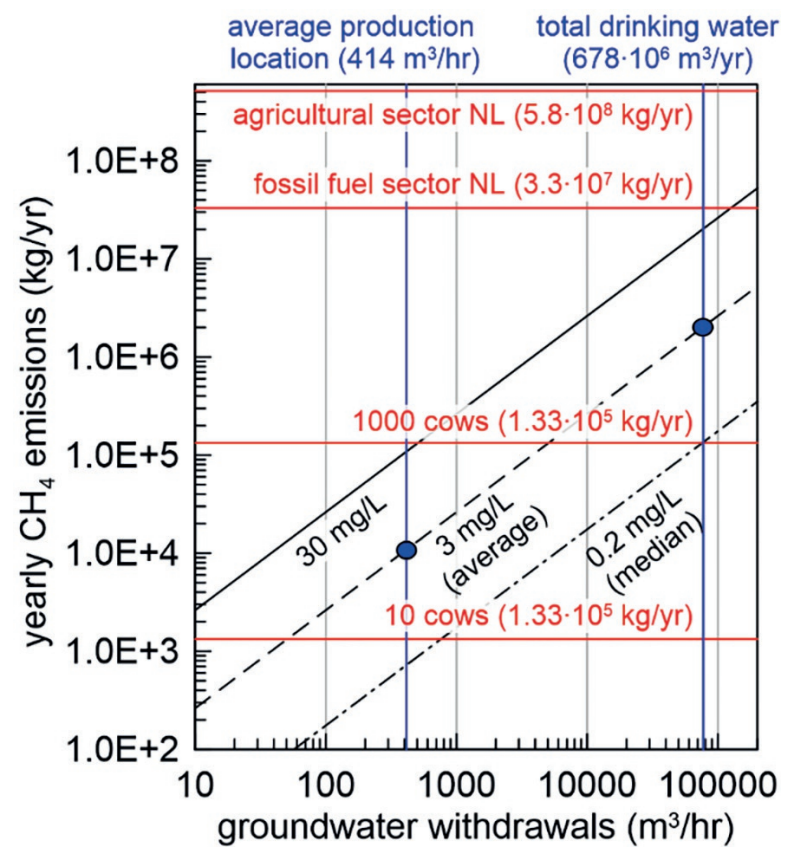

Figure 3 | Methane emissions from groundwater withdrawals in the Netherlands. Average emission per milk cow in the Netherlands is $\sim 133 \mathrm{~kg} \mathrm{CH}$ (Velthof et al., 2016). Methane emissions from the agricultural and energy sectors are for 2015 (Environmental Data Compendium, 2017), assuming $1 \mathrm{~kg}$ $\mathrm{CH}_{4}$ is equivalent to $25 \mathrm{~kg} \mathrm{CO}$ in terms of global warming potential. Blue dots highlight the coarse first estimates for methane emissions from groundwater with-drawal by an average production location $\left(1.09 \cdot 10^{4} \mathrm{~kg} \mathrm{CH}_{4} \cdot \mathrm{yr}^{-1}\right)$ and that of the total drinking water sector (2.03.10 $\left.\mathrm{kg} \mathrm{CH}_{4} \cdot \mathrm{yr}^{-1}\right)$.

\subsection{FATE AND DETECTION OF METHANE LEAKING FROM THE DEEP SUBSURFACE}

The fate of methane leaking from depth through the wellbore system and entering into the subsurface environment (i.e. gas migration) is impacted by a variety of processes that can disperse, retain and degrade it, delaying or ending its upward migration. These physical and chemical processes include gas phase trapping, dispersion, lateral migration, dissolution and oxidation. As shown in this work, the combination of these processes may cause the detection of methane leakage to become highly challenging in practice. For the purposes of this discussion, methane leaking entirely through the wellbore system towards the surface is not considered. Subsurface retention of methane is presumably much less significant for such leaks and detection is relative straightforward, using either surface casing vent flow (SCVF) or surface casing pressure (SCP) measurement (assuming the wellhead is still intact). Methods for analysis and interpretation of SCVF and SCP were extensively discussed by Lackey et al. (2017) and Lackey and Rajaram (2018). 
The fraction of leaks that result in gas migration in the subsurface compared to those where methane migrates strictly through the wellbore system is currently still unclear. Due to the difficulties associated with measuring gas migration, datasets with strictly SCVF and SCP measurements are much more common. A recent study of 3276 wells with reported subsurface gas migration issues in Alberta, Canada, showed that $63 \%$ suffered only from gas migration, and did not have SCVF (Bachu, 2017). This highlights that in many cases the total leakage flux may be in the form of subsurface gas migration, and implies that the absence of SCVF and SCP cannot be seen as proof that leakage is not occurring. Furthermore, gas migration through the subsurface will also occur at leaking gas wells that have already been cut and buried to below ground surface (as there is no longer a pathway for leaking gas to escape directly to the atmosphere through the wellbore system), and will also result from leaks that manifest through fractures induced by for example the hydraulic fracturing process. For all these reasons, research that improves our understanding of methane migration and retention in the subsurface is vital.

Methane retention in the gaseous phase can become significant when low permeability layers are present, which slow down the migrating gas phase and cause the gas phase saturation to become larger than in high permeability layers (chapter 5). Such low permeability layers also spread out migrating gas laterally, a finding that is corroborated by field experiments of methane injection into shallow unconfined aquifers (Cahill et al., 2018), and cause surficial methane effluxes to become displaced from their lateral position of origin. Spatially distributed, localized surficial methane fluxes were also encountered in chapter 3 of this study above abandoned well NKK-01. However, this methane was biogenic in nature and could therefore not be attributed to the remnants of the underlying gas well. Besides causing lateral spreading and localized fluxes, permeability contrasts have also been shown to result in temporally intermittent methane effluxes to the surface (Forde et al., 2018). This intermittent nature of gas leakage was also noted by Dusseault et al (2014), who therefore suggest that periodic sampling is required to reliably detect leakage. Indeed, these combined results highlight the spatial and temporal variability of gas migration, and the vulnerability of single point measurements to returning false negatives.

In the experiments by Cahill et al., (2018), where methane was injected at $9 \mathrm{~m}$ bgs, only $30 \%$ of injected methane flux was accounted for by surficial flux measurements. Isotopic evidence suggested that microbial methane oxidation had occurred. Therefore, some portion of leaking methane was likely emitted as $\mathrm{CO}_{2}$, which was not measured. The importance of oxidation in the vadose zone was also apparent in this study from the subsurface measurements carried out at well MON-02 (chapter 3). Here, oxidation was estimated to account for up to $25 \%$ of the reduction in flux from $2 \mathrm{~m}$ depth to $1 \mathrm{~m}$ depth. At the Sleen blowout site (chapter 4), high methane flow rates were also measured directly above the area where the blowout had occurred. However, methane isotopes showed a biogenic origin, in spite of the underlying groundwater having thermogenic methane concentrations near saturation. This outcome also shows that mixing of thermogenic methane with biogenic methane generated in the vadose zone can further mask gas migration. Together, these 
results show that vadose zone processes, and particularly aerobic oxidation, can have a large effect on the detectability of methane leaks. This holds even more for areas that have deep groundwater tables (uncommon for those areas in the Netherlands where gas is produced). Measuring the $\mathrm{CO}_{2}$ flux and isotopic composition together with that of methane could therefore be a worthwhile addition to future investigations.

Retention of methane through dissolution in laterally flowing groundwater was shown to be significant for nearly all scenarios with methane leakage fluxes of $1 \mathrm{~m}^{3} \cdot \mathrm{d}^{-1}$ or lower and groundwater velocities in excess of $1 \mathrm{~m} . \mathrm{yr}^{-1}$ in chapter 5 of this thesis. Lateral spreading of migrating gas induced by permeability contrasts greatly enhances this dissolutive retention, to where fluxes of $10 \mathrm{~m}^{3} \cdot \mathrm{d}^{-1}$ could also be entirely retained in the subsurface. While such dissolution may cause leakage to remain unnoticed for long periods of time, it also prevents greenhouse gas emissions from occurring. However, depending on the hydrogeological setting, such emissions may still occur at much later times and large offset distances, depending on the groundwater flow path. This is illustrated by the use of thermogenic methane measurements in streams as an indicator of methane leakage occurring from hydrocarbon wells to groundwater, that subsequently discharges into this stream (Heilweil et al., 2015).

After dissolution, anaerobic oxidation of methane (AOM) may cause further attenuation of the migrating methane plume. Field-based studies have shown that anaerobic methane oxidation coupled to either sulphate reduction (Van Stempvoort et al., 2005) and/or reduction of iron and manganese oxides (Van Breukelen and Griffioen, 2004; chapter 4) can be significant. In combination with the often low velocities of groundwater, this may cause the impact of methane leakage on groundwater to only be detectable within a relatively small distance of the leakage point. For example, after 50 years of leakage following the blowout described in chapter 5 , thermogenic methane was only observed up to a maximum distance of around $515 \mathrm{~m}$. In contrast, only 56 out of a total of 3250 sampling locations that comprise the methane concentration dataset in chapter 2 were collected from groundwater wells within $1 \mathrm{~km}$ from a gas well. This shows that a such a dataset is unlikely to uncover methane leakage from gas wells, even if it was occurring.

\subsubsection{Recommendations for effective monitoring and risk mitigation}

There are about 2,500 hydrocarbon wells in the Netherlands, that will ultimately all be abandoned. Current practice is that well integrity is checked during their active lifetime, and during abandonment, but not afterwards. However, previous researchers have concluded that the problem of methane leakage is likely latent and long-term in consequence (Dusseault and Jackson, 2014). This assertion was corroborated by observations in this work of methane leakage sustaining over multiple decades (chapter 4) and possibly requiring several decades to even reach the surface (chapter 5). Given the challenges associated with leak detection, deploying a full scale, post abandonment monitoring program for each well will be a costly exercise, particularly if a high degree of certainty about leak detection is demanded. Compared to other methods, installation of purpose-built multi- 
level groundwater monitoring wells at all abandoned well locations would provide a high leak detection probability (Dusseault et al., 2014), although it still does not guarantee leak detection. Furthermore, both construction and regular sampling of these wells would be highly expensive. In the Netherlands, where biogenic methane is abundantly present in the shallow subsurface, the costs of post-abandonment monitoring of oil and gas wells in this manner would probably not be proportional to the environmental impact of methane leakage. Therefore, a more pragmatic solution is required, in which environmental impact, costs and detection likelihood are more balanced.

Such a monitoring programs should consist of either sample collection using soil gas probes or subsurface flux measurement above holes drilled into ground using hand augers, as was done in chapter 3. These methods strike a more realistic balance between cost invested and detection likelihood. Monitoring could be conducted at each well location every several years after a well has been decommissioned, as was proposed for the UK by Davies et al (2014). They suggested a 5 year interval between monitoring events, which would eventually imply around 500 monitoring events per year for all hydrocarbon wells in the Netherlands. A perhaps more feasible option would be to have a relatively high monitoring frequency initially after abandonment, which then decreases with time: for example, monitoring after 1 , 2, 5 and 10 years. Depending on whether leakage was detected monitoring could ultimately be stopped. Furthermore, the results of such a program could be used to inform a smarter, tailor made monitoring program, where the frequency of monitoring is increased for more at-risk subsets of wells and decreased for low-risk subsets.

The soil gas measurements should be conducted in grid-like fashion, for example, one directly above the well, and four more measurements $5 \mathrm{~m}$ removed in each direction. Due to the diffusive migration of methane in the vadose zone (Forde et al., 2018), this setup would still yield a relatively high detection probability while still being inexpensive compared to installation and sampling of groundwater monitoring wells. Collected samples should be analysed at minimum for methane and ethane content, which in many cases could suffice to fingerprint methane origin. However, ambiguities may arise due to oxidation, mixing, and solubility fractionation. Adding $\delta^{13} \mathrm{C}$ and $\delta D$ of methane would therefore probably be advisable. Some research and/or environmental monitoring programs have also used mobile atmospheric methane concentration measurements (e.g. Hensen et al., 2017) or methane concentrations measurements at the soil surface (e.g. Boothroyd et al., 2016). Although probably even less costly than the soil gas measurements, the detection probability of these methods would be such that the results could only reliable inform about the risk of atmospheric methane emissions, and not whether leakage to groundwater or the vadose zone is occurring.

In terms of legislation, the possibility of not cutting wells to below surface as part of final abandonment therefore deserves consideration. Leaving a surficial marker that can be used to access the well via tubing into the remainder of the wellbore system would yield very high leak detection likelihood, and sampling of such locations would be quick and therefore inexpensive. The obvious downside of implementing such a practice is that, at 
least superficially, the land cannot be restored to its original state. Furthermore, land use will have to account for the access to the well location (e.g. no building over it).

The hazards of methane leakage can be further mitigated by instituting a no build zone policy above old cut and buried wells. A no build zone policy has already been implemented in some municipalities in Alberta, Canada (Alberta Energy Regulator, 2014), where a setback distance of at least $5 \mathrm{~m}$ has to be maintained. Such a distance is not a guarantee for safety however, and surface effluxes up to $20 \mathrm{~m}$ from the wellhead of a leaking well were detected by Forde et al., 2019. In chapter 5 of this work, lateral migration of gaseous methane during upward migration caused by the hydraulic pressure gradient was up to $30 \mathrm{~m}$ in some simulations. In reality, no realistic setback distance could be large enough to completely guarantee safety, as lateral gaseous flow through preferential flow paths can be as large as several kilometres (Moortgat et al., 2018). For future buildings where a no build zone was not an option, or for buildings that have already been constructed above abandoned wells, a regular monitoring program should be put in place. Alternatively, permanent methane concentration monitoring equipment could be installed sub slab or in cellars, basements, and other spaces where leaking gas may readily accumulate.

\subsubsection{Implications for leakage of non-methane gasses and gas mixtures}

Gas leakage resulting from human interference in the deep subsurface may also be caused by other activities than hydrocarbon production. For example, deep wells other than hydrocarbon wells may cross gas charged formations that can also lead to leakage of natural gas (e.g. D'Aniello et al., 2019). Furthermore, leaking gas does not necessarily have to consist of methane. Deployment of gas sequestration and storage facilities for non-methane gasses such as $\mathrm{CO}_{2}$, hydrogen, and compressed air is expected to occur in the coming decades. Present day underground natural gas storage facilities are known to suffer from similar leakage problems as the ones associated with regular oil and gas production (Chen et al., 2013). Hence, leakage of $\mathrm{CO}_{2}$, hydrogen, and air (mainly $\mathrm{N}_{2}$ and $\mathrm{O}_{2}$ ) would eventually also be expected to occur at some locations (Bauer et al., 2013). The different chemical properties of these other molecules may result in different environmental fates than that of methane, which affects both their detectability and for implications for water quality. Here, the implications of the findings of this work for the fate and detection of leakages consisting of these other gasses are briefly discussed.

Unlike $\mathrm{CH}_{4}, \mathrm{CO}_{2}$ exposure directly impacts groundwater by increasing acidity and decreasing alkalinity. The impact of $\mathrm{CO}_{2}$ on groundwater composition is therefore more immediate than that of $\mathrm{CH}_{4^{\prime}}$ and its severity is dependent on the sediment composition. Aquifers with reactive silicate, carbonate and clay minerals are most at risk due to mobilization of hazardous trace elements (Cahill et al., 2013). Laboratory incubation experiments where different aquifer sediments were exposed to $\mathrm{CO}_{2}$ have indeed shown that leakage of $\mathrm{CO}_{2}$ to freshwater aquifers may result in unwanted increases in concentrations of for example uranium and barium (Little and Jackson, 2010). Another notable difference between methane and $\mathrm{CO}_{2}$ is that the solubility of $\mathrm{CO}_{2}$ in shallow freshwater aquifers is almost two 
orders of magnitude larger than that of methane (Table 2). Due to this difference, leakage of $\mathrm{CO}_{2}$ originating at depth would be more prone to subsurface retention by dissolution than methane is.

Table 2 | Comparison of Henry's coefficient values $\left(\mathrm{H}_{\mathrm{CP}}\right)$, molecular weight and solubilities of common gasses at atmospheric pressure and $10^{\circ} \mathrm{C}$.

\begin{tabular}{lccccc}
\hline Molecule & $\begin{array}{c}\mathrm{H}_{\mathrm{cP}} @ 10^{\circ} \mathrm{C} \\
{\left[\mathrm{mol} \mathrm{L}^{-1} \mathbf{~ a t m}^{-1}\right]}\end{array}$ & $\mathrm{H}_{\mathrm{cP}} / \mathrm{H}_{\mathrm{cP}, \mathrm{CH} 4}$ & $\begin{array}{c}\text { Solubility @ } \\
1 \text { atm }\left[\mathrm{mol} \mathrm{I}^{-1}\right]\end{array}$ & $\begin{array}{c}\mathbf{M}_{\mathrm{wt}} \\
{\left[\mathrm{mg} \mathrm{mol}^{-1}\right]}\end{array}$ & $\begin{array}{c}\text { Solubility @ } \\
1 \text { atm [mg l-1] }\end{array}$ \\
\hline $\mathrm{CH}_{4}$ & $1.9 \mathrm{E}-3$ & 1.00 & $1.9 \mathrm{E}-3$ & 16,040 & 31 \\
\hline $\mathrm{C}_{2} \mathrm{H}_{6}$ & $2.8 \mathrm{E}-3$ & 1.46 & $2.8 \mathrm{E}-3$ & 30,070 & 84 \\
\hline $\mathrm{CO}_{2}$ & $5.1 \mathrm{E}-2$ & 26.70 & $5.1 \mathrm{E}-2$ & 44,010 & 2256 \\
\hline $\mathrm{N}_{2}$ & $8.2 \mathrm{E}-4$ & 0.43 & $8.2 \mathrm{E}-4$ & 28,013 & 23 \\
\hline $\mathrm{H}_{2}$ & $8.5 \mathrm{E}-4$ & 0.44 & $8.5 \mathrm{E}-4$ & 2,016 & 2 \\
\hline $\mathrm{He}$ & $3.9 \mathrm{E}-4$ & 0.20 & $3.9 \mathrm{E}-4$ & 4,000 & 2 \\
\hline $\mathrm{O}_{2}$ & $1.7 \mathrm{E}-3$ & 0.90 & $1.7 \mathrm{E}-3$ & 31,998 & 55 \\
\hline $\mathrm{Ar}$ & $1.9 \mathrm{E}-3$ & 0.97 & $1.9 \mathrm{E}-3$ & 39,948 & 74 \\
\hline
\end{tabular}

Storage of compressed air for energy retention during times of surplus may introduce elevated levels of both nitrogen and oxygen to aquifers. While nitrogen is an inert gas, introducing oxygen into anoxic aquifers can result in unwanted chemical changes. On the other hand, oxygen introduction can also have desirable effects on groundwater composition, such as oxidation of $\mathrm{H}_{2} \mathrm{~S}$. In batch oxygen exposure experiments with pyrite containing sediments, acidification of groundwater caused by pyrite oxidation was responsible for zinc, nickel and cobalt concentrations increasing to above drinking water guidelines values (Descourvières et al., 2010). Besides oxygen, hydrogen is another reactive gas that could leak from the subsurface, as it is directly involved in a serious of microbially mediated hydrogenotrophic redox reactions, such as acetogenesis and sulphate reduction. Hydrogen exposure has even been shown to significantly stimulate methanogenesis through $\mathrm{CO}_{2}$ reduction in incubations with lake sediments (Winfrey et al., 1977). In terms of leak detection, increased acetate concentrations or depleted sulphate concentrations are therefore probably a more sensitive parameter than actual dissolved hydrogen concentrations. Further chemical changes likely include a significant increase in $\mathrm{pH}$, and the precipitation of both iron and manganese sulfides and carbonates (Berta et al., 2018).

The (molar) solubilities of air and hydrogen are roughly equal, and both are about half that of methane (Table 2). Dissolutive retention would thus be expected to be smaller than for methane. However, the aforementioned reactions could prove to be such a significant 
hydrogen sink that more hydrogen may be able to dissolve than what would be expected based on simulations assuming conservative (non-reactive) behaviour, as was assumed for the simulations with methane in chapter 5 of this work. These complex physiochemical interactions involved in hydrogen leakage would therefore be a worthwhile subject for future research.

Leakages of gasses of mixed composition may also occur. While a methane content of around $90 \%$ is a common value for natural gas reservoirs, hydrocarbon reservoirs may contain significant fractions of for example nitrogen or $\mathrm{CO}_{2}$. Notably, several Dutch gas reservoirs are well known for containing large fractions of nitrogen (De Jager and Visser, 2017). Besides changing the potential water quality impacts of leakage from such reservoirs, the mixed composition also affects detectability. During upward migration the gasses with the largest solubilities are preferentially dissolved, which can change the gas composition measured at the surface or in shallow groundwater with respect to that of the source. This process is known as solubility fractionation, and is also observed between methane and ethane at certain geological gas seeps (Etiope et al., 2009). Due to the much large difference in solubility (Figure 4), the ratio between $\mathrm{CO}_{2} / \mathrm{CH}_{4}$ may be expected to be especially sensitivity to solubility fractionation, and the resulting ratio in shallow aquifers could be much lower than that of the gas reservoir at depth. Vice versa, the $\mathrm{N}_{2} / \mathrm{CH}_{4}$ ratio of the gas phase can be expected to increase during upward migration from the reservoir, although to a smaller degree than the $\mathrm{CO}_{2} / \mathrm{CH}_{4}$ ratio due to the smaller solubility difference.

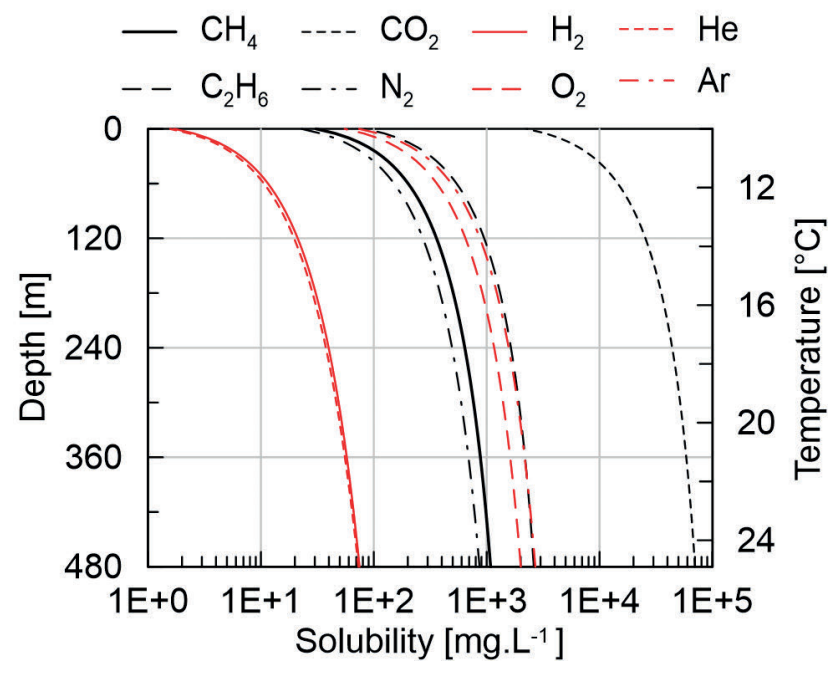

Figure 4 | Mass solubility of common gasses as a function of depth, according to Henry's law (Wilhelm et al., 1977). A mole fraction of 1 and a thermal gradient of $31.3^{\circ} \mathrm{C} / \mathrm{km}$ were assumed. 


\section{5 | THE RISKS OF METHANE LEAKAGE IN THE DUTCH CONTEXT}

Although the Netherlands is one of the main producers of oil and gas in Europe, the number of onshore hydrocarbon wells drilled ( 2500) is minor in comparison to countries such as the US (>2,600,000, Davies et al., 2014) and regions such as the Canadian state of Alberta ( 450,000, Bachu, 2017). Due to the difference in country size, the differences in terms of well density are smaller but still substantial: there are roughly 0.26 hydrocarbon wells per $\mathrm{km}^{2}$ in the US as a whole, compared to just 0.06 wells per $\mathrm{km}^{2}$ in the Netherlands (Table 3) - a major gas producing country in the European context. The largest number of wells in the Netherlands are found in the province of Drenthe, with 0.34 wells per $\mathrm{km}^{2}$, still only marginally higher than in the US as a whole. Regional well densities in the US can be much higher: for example, in the state of Pennsylvania, well-known for its long history in oil and gas production, there are estimated to be around 400,000 abandoned wells alone (Kang et al., 2014) which implies a well density of at least 3.35 wells per $\mathrm{km}^{2}$.

Furthermore, although potential shale gas reservoirs are present, no production of shale gas has taken place in the Netherlands, and the limited shale gas exploration that has occurred in European countries in general has now practically come to a stop (Bradbury and Smith, 2020). Shale gas production requires high volume hydraulic fracturing (HVHF), which carries with an added risk due to injection of hazardous fluids at high pressures. This creates another potential driving force for the migration of contaminants towards the shallow subsurface, besides natural overpressures and buoyancy driven flow of gasses. Additionally, to extract similar gas volumes shale gas production requires a larger number and higher density of wells than conventional gas production (Jackson et al., 2014). At the moment, shale gas production already accounts for the vast majority of onshore gas produced in the US (U.S. EIA, 2019). The large scale production of shale gas has therefore contributed to even higher local densities of wells in the US. In these areas of intense hydrocarbon exploitation, the risks of explosions, groundwater contamination, and GHG emissions are much more immediate than in, for example, the Netherlands. It is therefore not surprising that much of the concerns surrounding the environmental and safety hazards of oil and gas well drilling originated from areas were high density drilling has occurred, such as the shale gas producing regions in the US.

Table 3 | Estimates of hydrocarbon well density well. Data from the Netherlands retrieved from the Dutch Oil and Gas Portal (www.NLOG.nl).

\begin{tabular}{lcccc}
\hline & United States & State of Pennsylvania & Netherlands & Drenthe Province \\
\hline Land surface area [km²] & $9,834,000$ & 119,280 & 41,528 & 2,683 \\
\hline Hydrocarbon wells [\#] & $2,600,000^{1}$ & $400,000^{2}$ & 2,504 & 910 \\
\hline Well density [wells/km²] & 0.26 & 3.35 & 0.06 & 0.34 \\
\hline
\end{tabular}

'Davies et al (2014). ${ }^{2}$ Abandoned wells only, Kang et al. (2014). 


\subsubsection{Atmospheric methane emissions}

Methane leakage was observed to occur at 1 out of 29 investigated cut and buried abandoned oil and gas wells in chapter 3 (3.4\%). In a subsequent study, the State Supervision of Mines (SodM) tallied leakage of thermogenic gas at around $1.3 \%$ of onshore gas wells (SodM, 2019a), by visual observations of gas bubbles in flooded well cellars. Simple extrapolating of these numbers to all hydrocarbon wells in the Netherlands ( $n=2504$, Table 2) suggests that the total amount of leaking wells is in the order of 33 to 86 . The cumulative methane emissions from these wells is likely small compared to other anthropogenic sources (chapter 3), although it is important to emphasize that the true occurrence and magnitude of such emissions may still be underestimated due to the challenges associated with detecting leakage. Also, due to a lack of data on their leakage risk, oil wells were not treated separately in this assessment, and the integrity of the several hundred old oil wells in the Schoonebeek area has yet to be properly investigated. In general, oil wells may be expected to have a lower occurrence of methane leakage than gas wells (King and King, 2013). However, given their larger age and presumably lower quality of well completion, the leakage risk and emissions from these old wells deserves further investigation.

\subsection{2 | Explosion hazard}

The relatively low density of wells also implies that the risk of explosions occurring due to methane leakage is comparatively small in the Netherlands. However, building density is high, and an explosion caused by gas migration from a leaky well would be considered a disaster. The leakage detected as part of this work at well MON-02 (chapter 3), which was immediately acted upon by the responsible operator by remedial cementing of the leaking wellbore, received considerable public attention in both local and national media. This quick response and media attention was partly due to the fact that the well was situated on a plot of land where housing development was scheduled to occur within months of the detection. To mitigate the hazard of explosions caused by methane leakage in the Netherlands, an investigation into already abandoned wells in the country is advisable. An investigation on this subject has indeed already been announced by the State Supervision of Mines (SodM, 2019b). Locations where buildings have already been built over or that are within close distance to abandoned wells (e.g. $15 \mathrm{~m}$ ) should be subjected to regular monitoring. Furthermore, unless stringent monitoring and mitigation measures are put in place, buildings should no longer be built above cut-and-buried abandoned wells as a safety precaution. Besides implementing such a monitoring program and not building above abandoned wells, constructing surficial markers at abandoned wells rather than completely burying them below the surface can be an additional safety measure. This will ensure that future generations are also aware of the legacy infrastructure existing in the subsurface.

\subsection{3 | Groundwater quality implications}

Detrimental hydrogeochemical effects of methane introduction into groundwater aquifers are due to secondary chemical changes in groundwater. Introduction of methane can 
lead to changes in redox conditions, which alters the $\mathrm{pH}$ of groundwater and can increase concentrations of redox sensitive components such as iron and sulphide (Kelly et al., 1985). Mobilization of trace elements such as nickel, that can be toxic at low concentrations, has been observed in a controlled field experiments where methane was released in an unconfined aquifer (Cahill et al., 2017). Similarly, some mobilization of chromium and selenium was predicted on the basis of numerical simulations (Schwartz, 2015). Still, these studies all concluded that the water quality impacts of methane leakage can be considered minor. Depending on the conditions, an increase in $\mathrm{pH}$ induced by anaerobic methane oxidation may even reduce the concentration of such trace elements, as adsorption to iron minerals is increased (Appelo and Postma, 2004).

A risk to groundwater that has thus far received little attention is the degree to which BTEX components are present in natural gas accumulations, and whether they also enter groundwater along with leaking natural gas. In the Netherlands, benzene soil gas concentrations exceeding the intervention limit were recently observed at 5 of 16 investigated locations where gas leakage from the distribution pipeline system was known to occur (Polman et al., 2018). In the groundwater monitoring wells near the blowout in Sleen, BTEX concentrations are already being monitored by the local drinking water company. Contamination with benzene from leaking gas wells would present a serious risk to groundwater quality, and therefore deserves further investigation.

In addition to its health hazard, methane also has to be removed during groundwater production due to the hazard of explosions occurring in the distribution network. It should of course be mentioned here that methane naturally occurs ubiquitously in groundwater in the Netherlands, and locally in concentrations up to solubility (chapter 2). Typically, methane would be removed by already in place filtration methods at drinking water production plants (e.g. oxygenation/aeration). Also, elevated iron concentrations due to anaerobic methane oxidation by reductive dissolution of Fe oxides, as observed in groundwater near the blowout in Sleen (up to $60 \mathrm{mg} \cdot \mathrm{L}^{-1}$, chapter 4), could pose a serious clogging issue for groundwater wells. Lastly, the presence of gaseous methane reduces hydraulic permeability and thereby the productivity of aquifers (Fortuin and Willemsen, 2005).

\subsubsection{Interwell communication}

In addition to the risks induced by methane leakage itself, it signals a subsurface conduit between the deep and shallow subsurface that would not naturally have existed. In other words, it implies there has been a loss of integrity of the natural geological barriers that prevent flow and transport from the deep to the shallow subsurface. The integrity of these barriers is crucial not only for the safe production of fossil fuels, but also for the successful implementation of other subsurface technologies. Indeed, 'interwell communication' - the injection of fluids in one well leading to leakage of fluids through another, offset well - is already a known concern in areas of shale gas production in Canada (Bachu and Valencia, 2014). While shale gas production has been banned in the Netherlands, several technologies that are involved in the sustainable energy transition also depend on their 
use of the subsurface, including $\mathrm{CO}_{2}$ sequestration, geothermal energy production and hydrogen storage. When well integrity issues remain undiscovered or are left unmitigated, the presence of legacy hydrocarbon and other deep wells may therefore limit the potential for these sustainable technologies in the Netherlands.

\subsection{5 | Concluding remarks}

All things considered, it is important that methane leakage is further studied and that lessons learned are utilized to optimize well construction, abandonment and monitoring practices. Besides its environmental impact, leakage incidents also impact the social license to utilize the deep subsurface. As demonstrated by the growing resistance to new onshore drilling of gas wells in the Netherlands due to the induced seismicity issues in the Groningen province, a diminishing social license can prove to be a serious barrier to future utilization of the subsurface (van den Beukel and van Geuns, 2019), also for technologies that contribute to the sustainable energy transition. In order to avoid this, the risks associated with all these activities need to be clearly and transparently communicated prior to operations. It is impossible to entirely prevent undesirable events such as methane leakage from occurring, in spite of using best practices. When they do occur, they should be quickly and transparently dealt with, and those affected should be adequately compensated. Only then can future utilization of the deep subsurface be conducted in a safe manner that is beneficial to the entire society. 


\section{REFERENCES}

Alberta Energy Regulator, 2014. Directive 079: Surface Development in Proximity to Abandoned Wells. Appelo, C.A.J., Postma, D., 2004. Geochemistry, groundwater and pollution, second edition, Geochemistry, Groundwater and Pollution, Second Edition. CRC Press. https://doi. org/10.1201/9781439833544

Bachu, S., 2017. Analysis of gas leakage occurrence along wells in Alberta, Canada, from a GHG perspective - Gas migration outside well casing. Int. J. Greenh. Gas Control 61, 146-154. https:// doi.org/10.1016/j.ijggc.2017.04.003

Bachu, S., Valencia, R.L., 2014. Well Integrity Challenges and Risk Mitigation Measures. Bridg. 44, 28-33.

Bauer, S., Beyer, C., Dethlefsen, F., Dietrich, P., Duttmann, R., Ebert, M., Feeser, V., Görke, U., Köber, R., Kolditz, O., Rabbel, W., Schanz, T., Schäfer, D., Würdemann, H., Dahmke, A., 2013. Impacts of the use of the geological subsurface for energy storage: An investigation concept. Environ. Earth Sci. 70, 3935-3943. https://doi.org/10.1007/s12665-013-2883-0

Bell, R.A., Darling, W.G., Ward, R.S., Basava-Reddi, L., Halwa, L., Manamsa, K., Ó Dochartaigh, B.E., 2017. A baseline survey of dissolved methane in aquifers of Great Britain. Sci. Total Environ. 601-602, 1803-1813. https://doi.org/10.1016/j.scitotenv.2017.05.191

Berta, M., Dethlefsen, F., Ebert, M., Schäfer, D., Dahmke, A., 2018. Geochemical Effects of Millimolar Hydrogen Concentrations in Groundwater: An Experimental Study in the Context of Subsurface Hydrogen Storage. Environ. Sci. Technol. 52, 4937-4949. https://doi.org/10.1021/ acs.est.7b05467

Bol, J., 1991. Moeras- of brongas. Grondboor en Hamer 150-153.

Boothroyd, I.M., Almond, S., Qassim, S.M., Worrall, F., Davies, R.J., 2016. Fugitive emissions of methane from abandoned, decommissioned oil and gas wells. Sci. Total Environ. 547, 461-469. https:// doi.org/10.1016/j.scitotenv.2015.12.096

Bradbury, J.D., Smith, C.C., 2020. Global Conflicts Surrounding Hydraulic Fracturing and Water. Springer, Cham, pp. 69-85. https://doi.org/10.1007/978-3-030-18342-4_4

Cahill, A.G., Jakobsen, R., Mathiesen, T.B., Jensen, C.K., 2013. Risks attributable to water quality changes in shallow potable aquifers from geological carbon sequestration leakage into sediments of variable carbonate content. Int. J. Greenh. Gas Control 19, 117-125. https://doi.org/10.1016/j. ijggc.2013.08.018

Cahill, A.G., Parker, B.L., Mayer, B., Mayer, K.U., Cherry, J.A., 2018. High resolution spatial and temporal evolution of dissolved gases in groundwater during a controlled natural gas release experiment. Sci. Total Environ. 622-623, 1178-1192. https://doi.org/10.1016/j.scitotenv.2017.12.049

Cahill, A.G., Steelman, C.M., Forde, O., Kuloyo, O., Emil Ruff, S., Mayer, B., Ulrich Mayer, K., Strous, M., Cathryn Ryan, M., Cherry, J.A., Parker, B.L., 2017. Mobility and persistence of methane in groundwater in a controlled-release field experiment. Nat. Geosci. https://doi.org/10.1038/ ngeo2919

Chen, M.J., Buscheck, T.A., Wagoner, J.L., Sun, Y.W., White, J.A., Chiaramonte, L., Aines, R.D., 2013. Analysis of fault leakage from Leroy underground natural gas storage facility, Wyoming, USA. Hydrogeol. J. 21, 1429-1445. https://doi.org/10.1007/s10040-013-1020-1

Christian, K.M., Lautz, L.K., Hoke, G.D., Siegel, D.I., Lu, Z., Kessler, J., 2016. Methane occurrence is associated with sodium-rich valley waters in domestic wells overlying the Marcellus shale in New York State. Water Resour. Res. 52, 206-226. https://doi.org/10.1002/2015WR017805 
Cirkel, G., Hartog, N., De La, B., Gonzalez, L., Stuyfzand, P., 2015. Methaan in ondiep Nederlands grondwater: verbinding met de diepe ondergrond? $\mathrm{H} 2 \mathrm{O}$.

D'Aniello, A., Fabbricino, M., Ducci, D., Pianese, D., 2019. Numerical Investigation of a Methane Leakage from a Geothermal Well into a Shallow Aquifer. Groundwater. https://doi.org/10.1111/ gwat.12943

Davies, R.J., Almond, S., Ward, R.S., Jackson, R.B., Adams, C., Worrall, F., Herringshaw, L.G., Gluyas, J.G., Whitehead, M.A., 2014. Oil and gas wells and their integrity: Implications for shale and unconventional resource exploitation. Mar. Pet. Geol. 56, 239-254. https://doi.org/10.1016/j. marpetgeo.2014.03.001

De Jager, J., Visser, C., 2017. Geology of the Groningen field - An overview. Geol. en Mijnbouw/ Netherlands J. Geosci. 96, s3-s15. https://doi.org/10.1017/njg.2017.22

Descourvières, C., Hartog, N., Patterson, B.M., Oldham, C., Prommer, H., 2010. Geochemical controls on sediment reactivity and buffering processes in a heterogeneous aquifer. Appl. Geochemistry 25, 261-275. https://doi.org/10.1016/j.apgeochem.2009.11.012

Doppert, J.W.C., Ruegg, G.H.J., van Staalduinen, C.J., Zagwijn, W.H., Zandstra, J.G., 1975. Formaties van het Kwartair en Boven-Tertiair in Nederland, in: Zagwijn, W.H., van Staalduinen, C.J. (Eds.), Toelichting Bij Geologische Overzichtskaarten van Nederland. Rijks Geologische Dienst, Haarlem, The Netherlands, pp. 11-56.

Dusseault, M., Jackson, R., 2014. Seepage pathway assessment for natural gas to shallow groundwater during well stimulation, in production, and after abandonment. Environ. Geosci. 21, 107-126. https://doi.org/10.1306/eg.04231414004

Dusseault, M.B., Jackson, R.E., MacDonald, D., 2014. Towards a Road Map for Mitigating the Rates and Occurrences of Long-Term Wellbore Leakage. Geofirma 1-69.

Environmental Data Compendium, 2017. Greenhouse gas emissions the Netherlands, 1990-2016 [WWW Document]. URL http://www.clo.nl/en/indicators/en0165-greenhouse-gas-emissions (accessed 7.7.18).

Etiope, G., Feyzullayev, A., Baciu, C.L., 2009. Terrestrial methane seeps and mud volcanoes: A global perspective of gas origin. Mar. Pet. Geol. 26, 333-344.

Forde, O.N., Mayer, K.U., Cahill, A.G., Mayer, B., Cherry, J.A., Parker, B.L., 2018. Vadose Zone Gas Migration and Surface Effluxes after a Controlled Natural Gas Release into an Unconfined Shallow Aquifer. Vadose Zo. J. 17, 0. https://doi.org/10.2136/vzj2018.02.0033

Forde, O.N., Mayer, K.U., Hunkeler, D., 2019. Identification, spatial extent and distribution of fugitive gas migration on the well pad scale. Sci. Total Environ. 652, 356-366. https://doi.org/10.1016/j. scitotenv.2018.10.217

Fortuin, N.P.M., Willemsen, A., 2005. Exsolution of nitrogen and argon by methanogenesis in Dutch ground water. J. Hydrol. 301, 1-13.

Griffioen, J., Vermooten, S., Janssen, G., 2013. Geochemical and palaeohydrological controls on the composition of shallow groundwater in the Netherlands. Appl. Geochemistry 39, 129-149. https://doi.org/10.1016/j.apgeochem.2013.10.005

Heilweil, V.M., Grieve, P.L., Hynek, S.A., Brantley, S.L., Solomon, D.K., Risser, D.W., 2015. Stream measurements locate thermogenic methane fluxes in groundwater discharge in an area of shale-gas development. Environ. Sci. Technol. 49, 4057.

Heisig, P.M., Scott, T.-M., 2013. Occurrence of methane in groundwater of south-central New York State, 2012- Systematic evaluation of a glaciated region by hydrogeologic setting. Sci. Investig. Rep. 2013-5190. https://doi.org/10.3133/sir20135190 
Hendry, M.J., Schmeling, E.E., Barbour, S.L., Huang, M., Mundle, S.O.C., 2017. Fate and Transport of Shalederived, Biogenic Methane. Sci. Rep. 7, 2-10. https://doi.org/10.1038/s41598-017-05103-8

Hensen, A., van den Bulk, W.C.M., van Dinther, D., 2017. Methaan emissiemetingen aan buiten gebruik gestelde olie- en gaswinningsputten.

Hoekstra, N., Kruiver, P., Marsman, A., Bakker, M., 2010. Minder zorgen om stortplaatsen : naar een risicobeoordeling van gesloten stortplaatsen.

Humez, P., Mayer, B., Ing, J., Nightingale, M., Becker, V., Kingston, A., Akbilgic, O., Taylor, S., 2016. Occurrence and origin of methane in groundwater in Alberta (Canada): Gas geochemical and isotopic approaches. Sci. Total Environ. 541, 1253-1268. https://doi.org/10.1016/j.scitotenv.2015.09.055

Jackson, R.B., Vengosh, A., Carey, J.W., Davies, R.J., Darrah, T.H., Sullivan, F.O., Gabrielle, P., 2014. The Environmental Costs and Benefits of Fracking. Annu. Rev. Environ. Resour. 39, 327-362. https:// doi.org/10.1146/annurev-environ-031113-144051

Kang, M., Kanno, C.M., Reid, M.C., Zhang, X., Mauzerall, D.L., Celia, M.A., Chen, Y., Onstott, T.C., 2014. Direct measurements of methane emissions from abandoned oil and gas wells in Pennsylvania. Proc. Natl. Acad. Sci. 111, 18173-18177. https://doi.org/10.1073/pnas.1408315111

Kelly, W.R., Matisoff, G., Fisher, J.B., 1985. The effects of a gas well blow out on groundwater chemistry. Environ. Geol. Water Sci. 7, 205-213. https://doi.org/10.1007/BF02509921

King, G.E., King, D.E., 2013. Environmental Risk Arising From Well-Construction Failure--Differences Between Barrier and Well Failure, and Estimates of Failure Frequency Across Common Well Types, Locations, and Well Age. SPE Prod. Oper. 28, 323-344. https://doi.org/10.2118/166142-PA

Kulongoski, J.T., McMahon, P.B., 2019. Methane emissions from groundwater pumping in the USA. npj Clim. Atmos. Sci. 2, 1-8. https://doi.org/10.1038/s41612-019-0068-6

Kulongoski, J.T., McMahon, P.B., Land, M., Wright, M.T., Johnson, T.A., Landon, M.K., 2018. Origin of Methane and Sources of High Concentrations in Los Angeles Groundwater. J. Geophys. Res. Biogeosciences 123, 818-831. https://doi.org/10.1002/2017JG004026

Lackey, G., Rajaram, H., 2018. Modeling gas migration, sustained casing pressure, and surfacecasing-vent flow in onshore oil and gas wells. Water Resour. Res. 1-26. https://doi. org/10.1029/2018WR024066

Lackey, G., Rajaram, H., Sherwood, O.A., Burke, T.L., Ryan, J.N., 2017. Surface Casing Pressure As an Indicator of Well Integrity Loss and Stray Gas Migration in the Wattenberg Field, Colorado. Environ. Sci. Technol. 51, 3567-3574. https://doi.org/10.1021/acs.est.6b06071

Little, M.G., Jackson, R.B., 2010. Potential impacts of leakage from deep CO2 geosequestration on overlying freshwater aquifers. Environ. Sci. Technol. 44, 9225-9232. https://doi.org/10.1021/ es102235w

McIntosh, J.C., Hamilton, S.M., Grasby, S.E., Osborn, S.G., 2014. Origin, distribution and hydrogeochemical controls on methane occurrences in shallow aquifers, southwestern Ontario. Appl. Geochemistry 50, 37-52. https://doi.org/10.1016/j.apgeochem.2014.08.001

McMahon, P.B., Belitz, K., Barlow, J.R.B., Jurgens, B.C., 2017. Methane in aquifers used for public supply in the United States. Appl. Geochemistry 84, 337-347. https://doi.org/10.1016/j. apgeochem.2017.07.014

McPhillips, L.E., Creamer, A.E., Rahm, B.G., Walter, M.T., 2014. Assessing dissolved methane patterns in central New York groundwater. J. Hydrol. Reg. Stud. 1, 57-73. https://doi.org/10.1016/j. ejrh.2014.06.002 
Milkov, A. V., Etiope, G., 2018. Revised genetic diagrams for natural gases based on a global dataset of $>20,000$ samples. Org. Geochem. 125, 109-120. https://doi.org/10.1016/j. orggeochem.2018.09.002

Molofsky, L.J., Connor, J.A., McHugh, T.E., Richardson, S.D., Woroszylo, C., Alvarez, P.J., 2016. Environmental Factors Associated With Natural Methane Occurrence in the Appalachian Basin. Groundwater 54, 656-668. https://doi.org/10.1111/gwat.12401

Molofsky, L.J., Connor, J.A., Wylie, A.S., Wagner, T., Farhat, S.K., 2013. Evaluation of Methane Sources in Groundwater in Northeastern Pennsylvania. Groundwater 51, 333-349.

Moortgat, J., Schwartz, F.W., Darrah, T.H., 2018. Numerical Modeling of Methane Leakage from a Faulty Natural Gas Well into Fractured Tight Formations. Groundwater 56, 163-175. https://doi. org/10.1111/gwat.12630

Moritz, A., Hélie, J.-F., Pinti, D.L., Larocque, M., Barnetche, D., Retailleau, S., Lefebvre, R., Gélinas, Y., 2015. Methane Baseline Concentrations and Sources in Shallow Aquifers from the Shale Gas-Prone Region of the St. Lawrence Lowlands (Quebec, Canada). Environ. Sci. Technol. 49, 4765-4771. https://doi.org/10.1021/acs.est.5b00443

Nicot, J.P., Larson, T., Darvari, R., Mickler, P., Slotten, M., Aldridge, J., Uhlman, K., Costley, R., 2017 a. Controls on Methane Occurrences in Shallow Aquifers Overlying the Haynesville Shale Gas Field, East Texas. Groundwater 55, 443-454. https://doi.org/10.1111/gwat.12500

Nicot, J.P., Larson, T., Darvari, R., Mickler, P., Uhlman, K., Costley, R., 2017b. Controls on Methane Occurrences in Aquifers Overlying the Eagle Ford Shale Play, South Texas. Groundwater 55, 455-468. https://doi.org/10.1111/gwat.12506

Polman, E.A., Pulles, C.J.A., Nipshagen, A.A.., 2018. Vervolgonderzoek correlatie tussen gaslek en bodemverontreiniging door benzeen. Report GT-100136. Apeldoorn.

Schloemer, S., Elbracht, J., Blumenberg, M., Illing, C.J., 2016. Distribution and origin of dissolved methane, ethane and propane in shallow groundwater of Lower Saxony, Germany. Appl. Geochemistry 67, 118-132. https://doi.org/10.1016/j.apgeochem.2016.02.005

Schoell, M., 1980. The hydrogen and carbon isotopic composition of methane from natural gases of various origins. Grorhmica Cl Cosmochrmwa Arm 44.

Schwartz, M.O., 2015. Modelling the hypothetical methane-leakage in a shale-gas project and the impact on groundwater quality. Environ. Earth Sci. 73, 4619-4632. https://doi.org/10.1007/ s12665-014-3787-3

SodM, 2019a. De integriteit van onshore putten in Nederland. State Supervision of Mines. Den Haag.

SodM, 2019b. Methaan | Staatstoezicht op de Mijnen [WWW Document]. URL https://www.sodm.nl/ onderwerpen/methaan (accessed 3.1.20).

Stolper, D.A., Lawson, M., Formolo, M.J., Davis, C.L., Douglas, P.M.J., Eiler, J.M., 2018. The utility of methane clumped isotopes to constrain the origins of methane in natural gas accumulations. Geol. Soc. Spec. Publ. 468, 23-52. https://doi.org/10.1144/SP468.3

U.S. EIA, 2019. Annual Energy Outlook 2019 with projections to 2050. Annu. Energy Outlook 2019 with Proj. to 2050 44, 1-64. https://doi.org/DOE/EIA-0383(2012) U.S.

Van Breukelen, B.M., Griffioen, J., 2004. Biogeochemical processes at the fringe of a landfill leachate pollution plume: Potential for dissolved organic carbon, $\mathrm{Fe}(\mathrm{II}), \mathrm{Mn}$ (II), NH4, and CH4oxidation. J. Contam. Hydrol. 73, 181-205. https://doi.org/10.1016/j.jconhyd.2004.01.001

van den Beukel, J., van Geuns, L., 2019. Groningen gas: the loss of a social license to operate. The Hague. 
Van Stempvoort, D., Maathuis, H., Jaworski, E., Mayer, B., Rich, K., 2005. Oxidation of fugitive methane in ground water linked to bacterial sulfate reduction. Ground Water 43, 187-199. https://doi. org/10.1111/j.1745-6584.2005.0005.x

Velthof, G.L., Bruggen, C. Van, Groenestein, C.M., Huijsmans, J.F.M., Luesink, H.H., Sluis, S.M. Van Der, Van der Kolk, J.W.H., Voshaar, S.V.O., Vonk, J., Van Schijndel, M.W., 2016. Referentieraming van emissies naar lucht uit de landbouw tot 2030.; Achtergronddocument bij de Nationale Energieverkenning 2015, met emissies van ammoniak, methaan, lachgas, stikstofoxide en fijnstof uit de landbouw tot 2030. Wageningen.

Vewin, 2017. Drinkwaterstatistieken 2017; van bron tot kraan. Den Haag.

Whiticar, M.J., 1999. Carbon and hydrogen isotope systematics of bacterial formation and oxidation of methane. Chem. Geol. 161, 291-314. https://doi.org/10.1016/s0009-2541(99)00092-3

Wilhelm, E., Battino, R., Wilcock, R.J., 1977. Low-Pressure Solubility of Gases in Liquid Water. Chem. Rev. 77, 219-262. https://doi.org/10.1021/cr60306a003

Winfrey, M.R., Nelson, D.R., Klevickis, S.C., Zeikus, J.G., 1977. Association of hydrogen metabolism with methanogenesis in Lake Mendota sediments. Appl. Environ. Microbiol. 33, 312-318.

Zhu, J., Parris, T.M., Taylor, C.J., Webb, S.E., Davidson, B., Smath, R., Richardson, S.D., Molofsky, L.J., Kromann, J.S., Smith, A.P., 2017. Assessing Methane in Shallow Groundwater in Unconventional Oil and Gas Play Areas, Eastern Kentucky. Groundwater 1-12. https://doi.org/10.1111/gwat.12583 



\section{Summary}

Methane leakage resulting from oil and gas production presents a risk to groundwater quality, may contribute to greenhouse gas emissions, and poses an explosion hazard when allowed to accumulate in confined spaces. The research presented in this thesis examined the origin of methane in the Dutch subsurface, the physical and chemical fate of methane leaking to shallow groundwater and soil systems, and effective strategies for detecting methane leakage. The research was conducted using a combination of both field monitoring methods and numerical simulations. The specific research questions that were addressed are:

- What is the distribution and origin of methane in Dutch groundwater, and is there evidence for natural migration from the deep to the shallow subsurface?

- Does methane leakage occur at cut and buried abandoned gas wells in the Netherlands, what is the fate of methane migrating through the vadose zone, and how can such leakage be detected and quantified effectively?

- What is the effect of long term methane leakage on the chemistry of a shallow groundwater system, and what are the processes impacting methane fate in groundwater?

- How is methane migration through groundwater aquifers impacted by lateral flow and soil properties, and how does that affect the detectability of methane leakage?

\section{THE ORIGIN AND DISTRIBUTION OF METHANE IN SUBSURFACE OF THE NETHERLANDS}

The origin and distribution of methane in the subsurface of the Netherlands was assessed so that naturally occurring methane can be distinguished from methane that has migrated upward due to human interference in the deep subsurface, both resulting from past and potential future activities (Chapter 2). To that end, an existing dataset of groundwater methane concentrations throughout the Netherlands was analysed, in addition to a newly carried out sampling campaign, targeting locations where natural leakage from the deep subsurface was deemed most likely. Furthermore, these additional samples were not only analysed for methane concentrations, but also for dissolved gas molecular and isotopic composition. Our studies showed that methane is ubiquitous in Dutch shallow groundwater aquifers overlying the Neogene and Paleogene marine clay layers. These layers are typically found at depths of 100 to $500 \mathrm{~m}$, and are considered to be the hydrogeological base of the country. The $\delta^{13} \mathrm{C}$ and $\delta^{2} \mathrm{H}$ values of methane $\left(\mathrm{CH}_{4}\right)$ in samples collected in this groundwater compartment had a strictly local, microbial origin ('biogenic'), including the samples that 
were collected above major faults and/or gas reservoirs. Hence, no evidence was found for natural migration of thermogenic methane from the deep subsurface.

The biogenic methane in shallow groundwater was found in relatively high concentrations compared to values found in other countries, with $7.5 \%$ of samples exceeding $10 \mathrm{mg} / \mathrm{L}$ and a median of $0.2 \mathrm{mg} / \mathrm{L}$. The largest methane concentrations (up to $120 \mathrm{mg} / \mathrm{L}$ ) were observed in the coastal lowlands, where Holocene peats and marine clays rich in organic matter overly the Pleistocene aquifers. There, median concentrations peak at $4.0 \mathrm{mg} / \mathrm{L}$ between 20 to $40 \mathrm{~m}$ depth. However, at greater depths ( 100-160 m), median methane concentrations are lower in the coastal areas than in the rest of the country, most likely because of the presence of dissolved sulphate of seawater origin preventing microbial methanogenesis at these depths. Besides the surficial Holocene formations, other prominent sources of dissolved methane in Dutch shallow groundwater were shown to be the marine Eem Formation and the glacial Peelo Formation. Samples were also collected from deep groundwater wells (up to $871 \mathrm{~m}$ depth) below the Paleogene marine barriers. Methane was found in these samples in low concentrations only $(<1 \mathrm{mg} / \mathrm{L})$ and had a mixed biogenic/thermogenic origin. However, methane in geothermal wells, ranging in depth from $1640 \mathrm{~m}$ to $2625 \mathrm{~m}$, had an oil associated origin. Overall, the study showed that the thermogenic methane found in Dutch shallow groundwaters in future studies will most likely be attributable to migration from depth through anthropogenic rather than natural conduits.

\section{DETECTING METHANE LEAKING AT CUT AND BURIED ABANDONED GAS WELLS}

The occurrence of anthropogenic methane leakage from the deep subsurface was assessed at 29 abandoned wells in the Netherlands (Chapter 3). As in many other countries, oil and gas wells in the Netherlands that will no longer be used for production have to be plugged (i.e. filled with cement at specific depth intervals), cut to $3 \mathrm{~m}$ below surface, and then buried. While this allows the land to be superficially returned to its original state, it also hampers environmental monitoring. As such, little is known worldwide about the occurrence of methane leakage at wells abandoned in this manner. At the 29 studied wells, methane concentrations were first scanned at the soil-atmosphere interface in a circular area with a $15 \mathrm{~m}$ radius above the well. Then, methane flow rates were measured using static chamber measurements at the surface and above holes drilled $1 \mathrm{~m}$ into the surface. An anomalously high flow rate of methane from $1 \mathrm{~m}$ depth, combined with isotopic confirmation of its thermogenic origin, revealed ongoing leakage at one of the 29 wells (3.4\%). Notably, the leak had gone undetected by surficial measurements. Gas fluxes at the other sites were much smaller in magnitude and had a biogenic origin. 
Detailed investigation at the leaking well MON-02, consisting of 28 flux measurements conducted in a $2 \times 2 \mathrm{~m}$ grid from holes drilled to 1 and $2 \mathrm{~m}$ depth, showed that flux magnitude was spatially heterogeneous and consistently larger at $2 \mathrm{~m}$ depth compared to $1 \mathrm{~m}$. Enrichment of methane stable isotopes with decreasing depth revealed that aerobic oxidation accounted for roughly $25 \%$ of the decrease in flux towards the surface. The dispersion process is expected to further dilute the methane flux, resulting in fluxes at the surface that were below the detection limit of the surficial methods employed in this study. Therefore, the study shows that subsurface measurements greatly improve the likelihood of detecting leakage at cut and buried abandoned wells.

\section{THE IMPACT AND FATE OF METHANE LEAKING THROUGH A SHALLOW GROUNDWATER SYSTEM}

The long term impact and fate of methane in a shallow groundwater system was assessed at the location of a catastrophic gas well blowout that occurred near the village of Sleen in 1965 (Chapter 4). The results showed that, in water wells close to the location of the blowout, dissolved methane is still present in highly elevated concentrations. This methane was found to have a thermogenic isotopic signature that closely resembles that of the underlying gas reservoir. Thus, most likely, the long-term persistence of elevated methane concentrations is the result of continuing gas leakage from the reservoir, initiated by the blowout. Concentrations of both iron and manganese are highly elevated at the fringe of the migrating methane plume, and methane isotopic composition becomes increasingly more enriched with distance downstream of the blowout. Fractionation factors calculated using Rayleigh fractionation modelling fall within the low end of the range reported for anaerobic microbial methane oxidation. Together, this shows that anaerobic oxidation of methane, coupled to the reduction of iron and manganese oxides, plays a major role in the natural attenuation of the dissolved methane plume. However, the oxidation capacity is limited by the availability of iron and manganese oxides in the aquifer sediments, resulting in a slowly protruding methane plume. As dissolved thermogenic methane was only observed up to around $500 \mathrm{~m}$ from the location of blowout, the study highlighted that monitoring for gas contamination should be conducted in the closest possible proximity of potential leakage sources. In addition, the compositional and isotopic impact of oxidation may lead to erroneous assessment of the origin of dissolved gases, especially when $\delta^{13} \mathrm{C}$ is analysed without $\delta^{2} \mathrm{H}$. 


\section{THE INFLUENCE OF LATERAL GROUNDWATER FLOW ON MIGRATING METHANE}

Dissolution of methane gas into laterally flowing groundwater was shown to be an additional and thus far overlooked process that impacts methane fate (Chapter 5 ). This process was analysed using two-phase, two-component $\left(\mathrm{H}_{2} \mathrm{O}\right.$ and $\left.\mathrm{CH}_{4}\right)$ numerical simulations carried out using DuMux, an open-source simulator for flow and transport. A range of conditions were simulated that are representative of unconsolidated sandy aquifers that are typically found in the Netherlands and other sedimentary basins around the world. Results show that the retention of migrating methane due to dissolution into laterally flowing groundwater can become significant at ground water Darcy velocities as low as $1 \mathrm{~m} / \mathrm{yr}$. The dissolutive retention was found to be negligible in the absence of ground water flow. Besides groundwater velocity, both hydrogeological factors (permeability, entry pressure, pore-size distribution, and residual gas saturation) and leakage conditions (depth, magnitude and spatial dimensions) determined model outcomes.

Dissolutive retention of methane was even more significant in additional simulations representing horizontally layered stratigraphic sequences, and consisting of a number of alternating sedimentary units ranging from clays to sands. Under such conditions, depending on the imposed groundwater head gradient, imposed methane fluxes at the leakage point (up to $10 \mathrm{~m}^{3} / \mathrm{d}$ at atmospheric pressure and $10^{\circ} \mathrm{C}$ ) are entirely retained in the subsurface or can take several decades to fully develop. The simulations highlight that not only the presence of fine grained and low permeable layers may form barriers to upward gas migration, but also high permeability sands with relatively high groundwater flow velocities can do that, as this creates a larger dissolutive retention capacity. This study, therefore, showed that the dissolution of migrating gas may lead to actual wellbore leakage rates being underestimated, particularly when measuring surface expressions of gas migration.

\section{IMPLICATIONS}

With regards to the risk posed by anthropogenic methane leakage, this will vary from region to region depending on the amount and integrity of oil and gas wells, the native groundwater quality, and building density of the area. In the Netherlands, this study and recent work by the state supervisor SodM showed that of the roughly 2500 onshore oil and gas wells, several tens up to around a 100 of these wells may be leaking. Cumulatively, the estimations in the study show that these are likely not contributing significantly to the total anthropogenic methane emissions from the Netherlands. Locally, they may however pose an explosion hazard, as illustrated by the leakage discovered at well MON-02. On the plot of land above the remains of this well, construction of a housing block was scheduled to occur not long after the leak was detected as part of this study. Methane contamination of groundwater from these wells is undesirable. However, methane is already a common 
natural constituent of Dutch groundwater in many places, and is removed at drinking water production locations. Overall, in the Dutch context, the risk of methane leakage from oil and gas wells can be considered to be relatively low.

Concluding, the research presented in this thesis has shown that detection of methane leaking from deep subsurface through the wellbore system and entering into the subsurface environment can become highly challenging in practice, as the fate of migrating methane is impacted by a variety of processes that delay or even end its upward migration. Ideally, monitoring should therefore be carried out in close proximity to potential leakage sources and for long periods even after well abandonment. However, this would require dedicated multilevel groundwater wells at each oil and gas well, which would be costly both to construct and to sample. As there are already millions of oil and gas wells around the world, more pragmatic strategies are required. The insights gained in this study can be used to develop such a monitoring program. However, due to the aforementioned processes, a part of the leaking gas wells will likely remain unnoticed. 



\section{Samenvatting}

Methaanlekkage uit de diepe ondergrond, veroorzaakt door de productie van olie en gas, is een risico voor de grondwaterkwaliteit, draagt bij aan broeikasgasemissies als de lekkage het aardoppervlak bereikt, en vormt een explosiegevaar als het zich kan ophopen in afgesloten ruimtes. In dit proefschrift is onderzoek gedaan naar het voorkomen en de herkomst van methaan in de Nederlandse ondergrond, de fysische en chemische processen die het lot van methaan in de bodem en in grondwater bepalen, en de detectie van methaanlekkage bij verlaten aardgasputten. Het onderzoek is uitgevoerd door middel van een combinatie van zowel veldonderzoek alsmede numerieke simulaties. De volgende specifieke onderzoeksvragen zijn hierbij behandeld:

- Hoe is de ruimtelijke verdeling en herkomst van methaan in Nederlands grondwater, en is er bewijs voor natuurlijke migratie van methaan uit de diepe naar de ondiepe ondergrond?

- Komt methaanlekkage voor bij verlaten, ondergronds afgesneden olie- en gasputten in Nederland, en wat is de rol van aerobe oxidatie van methaan in de onverzadigde zone?

- Wat is het lange-termijn effect van methaanlekkage op de hydrogeochemie van een ondiep grondwatersysteem, en wat zijn de processen die het lot van methaan in grondwater bepalen?

- $\quad$ Hoe wordt methaanlekkage en het detecteren hiervan beïnvloed door laterale grondwater stroming en de doorlatendheid van watervoerende pakketten?

\section{HET VOORKOMEN EN DE DISTRIBUTIE VAN METHAAN IN DE NEDERLANDSE ONDERGROND}

Om methaan dat ten gevolge van menselijk handelen in diepe ondergrond naar ondiep grondwater is gelekt te kunnen onderscheiden van methaan dat er van nature voorkomt, is het natuurlijke voorkomen van methaan in gehele Nederlandse ondergrond beter in kaart gebracht (Hoofstuk 2). Hiervoor is een grote, reeds bestaande dataset gebruikt met concentraties van methaan opgelost in grondwater verzameld uit putten verspreid over heel Nederland. Daarnaast is een nieuwe bemonsteringscampagne uitgevoerd waarbij de genomen monsters niet alleen zijn geanalyseerd op de concentraties maar ook op de isotopensamenstelling van zowel methaan als andere opgeloste gassen, zoals $\mathrm{CO}_{2}$ en ethaan. Uit deze studie bleek dat methaan alom tegenwoordig is in Nederlands ondiep grondwater, ofwel boven de Neogene en Paleogene mariene kleilagen welke normaal gesproken op zo'n 100 tot 500 m diepte liggen, en beschouwd worden als de geohydrologische basis in het land. De $\delta^{13} \mathrm{C}$ en $\delta^{2} \mathrm{H}$ isotoopverhoudingen van methaan in grondwatermonsters uit dit compartiment toonden een duidelijke microbiologische oorsprong aan (of wel biogene 
oorsprong). Dit was ook het geval voor de monsters die verzameld waren boven belangrijke breuklijnen en gasvoorkomens in de diepe ondergrond, waar natuurlijke lekkage uit de diepe ondergrond het meest waarschijnlijk mag worden geacht. Kortom, er is dus geen bewijs gevonden voor natuurlijke lekkage van (diep gevormd) thermogeen methaan.

Methaan concentraties in Nederlands grondwater zijn relatief hoog in de internationale context, met een mediaan waarde van $0.2 \mathrm{mg} / \mathrm{l}$ en concentraties boven de $10 \mathrm{mg} / \mathrm{l}$ in $7.5 \%$ van demonsters. Dehoogsteconcentraties aan biogeen methaan (tot $120 \mathrm{mg} / \mathrm{l}$ ) zijn waargenomen in de kustgebieden, waar Holocene mariene formaties en veenafzettingen bovenop de Pleistocene watervoerende pakketten liggen. Hier reikte de mediaan methaanconcentraties tot $4 \mathrm{mg} / \mathrm{l}$ in het diepte interval van 20 tot $40 \mathrm{~m}$-mv (beneden maaiveld). Echter, op grotere diepte (grofweg 100 tot $160 \mathrm{~m}$-mv) waren de methaanconcentraties juist lager in de kustgebieden dan elders in het land. Dit komt vermoedelijk door de aanwezigheid van sulfaat in brak en zout grondwater met een mariene component, wat de microbiologische vorming van methaan afremt. Naast de oppervlakkige Holocene formaties bleken de mariene Eem Formatie en de glaciale Formatie van Peelo voorname bronnen van biogeen methaan te zijn. Als laatste zijn ook monsters verzameld uit diepe grondwaterputten (tot $871 \mathrm{~m}$-mv) onder de zogenaamde geohydrologische basis en geothermieputten (tot $2625 \mathrm{~m}$-mv). In de diepe grondwaterputten bevond zich enkel methaan in lage concentraties $(<1 \mathrm{mg} / \mathrm{l})$ met een gemixte biogene en thermogene oorsprong. Het methaan in de geothermieputten bleek een aan de vorming van olie gerelateerde thermogene oorsprong te hebben. In zijn geheel heeft deze studie aangetoond dat toekomstige waarnemingen van thermogeen methaan in ondiep Nederlands grondwater naar alle waarschijnlijkheid toegeschreven kunnen worden aan menselijk handelen in diepe ondergrond.

\section{HET DETECTEREN VAN METHAANLEKKAGE BIJ ONDERGRONDS AFGESNEDEN VERLATEN GASPUTTEN}

Het voorkomen van antropogene methaanlekkage uit de diepe ondergrond is beschouwd bij 29 verlaten putten in Nederland (Hoofdstuk 3). Net als in veel andere landen worden in Nederland olie- en gasputten die niet meer gebruikt worden uiteindelijk gedicht met 'plugs' van cement en onder de grond op minimaal $3 \mathrm{~m}$ diepte afgesneden en begraven. Dit heeft als voordeel dat het land aan het oppervlak naar zijn oorspronkelijke staat kan worden gebracht, met als nadeel dat dit het meten van methaanlekkage bemoeilijkt. Er is wereldwijd maar weinig bekend over het voorkomen van methaanlekkage bij olie- en gasputten die op deze manier zijn verlaten. Bij elk van de 29 putten in de studie zijn eerst de methaanconcentraties aan het maaiveld gemeten in een cirkel met een radius van $15 \mathrm{~m}$ boven de put. Daarna is de flux van methaan gemeten met een zogeheten bodemfluxkamer, eerst aan het maaiveld en daarna boven een boorgat met een diepte van $1.0 \mathrm{~m}$. Een zeer afwijkend hoge flux in combinatie met een thermogene isotoopsignatuur duidde op lekkage bij 1 van de 29 putten. Noemenswaardig is dat deze lekkage in zijn geheel niet gedetecteerd werd met de 
metingen aan het maaiveld, maar alleen met die op $1 \mathrm{~m}$ diepte. Bij de andere 28 locaties zijn beduidend lagere stroomsnelheden waargenomen, en allen met een biogene oorsprong.

Een gedetailleerder vervolgonderzoek is uitgevoerd bij de lekkende put in Monster (MON-02), bestaande uit 28 fluxmetingen uitgevoerd in een grid van $2 \times 2 \mathrm{~m}$ boven gaten van zowel 1 als 2 m diepte. Hieruit bleek dat de methaanflux ruimtelijke zeer heterogeen was, en consistent hoger op $2 \mathrm{~m}$ dan op $1 \mathrm{~m}$ diepte. Verrijking van de stabiele isotopenverhouding van methaan richting het maaiveld wees uit dat aerobe oxidatie verantwoordelijk was voor grofweg $25 \%$ van de vermindering in flux. Naast deze oxidatie zorgt dispersie ook voor verdere verdunning van het methaan, waardoor de uiteindelijke flux aan het maaiveld beneden de detectielimiet lag van de in deze studie uitgevoerde metingen. De studie toont daarom aan dat metingen in de bodem de kans op het detecteren van een methaanlek aanzienlijk vergroten.

\section{DE IMPACT EN HET LOT VAN METHAAN DAT LEKT DOOR EEN ONDIEP GRONDWATER SYSTEEM}

Het effect van methaanlekkage op de grondwaterchemie en het lot van methaan in een ondiep grondwater systeem zijn beschouwd nabij het dorp Sleen in Drente, waar in 1965 een catastrofale'blow-out'van gas plaatsvond bij het boren naar gas welke pas na enkele maanden gestopt kon worden (Hoofdstuk 4). Uit dit onderzoek bleek dat er in de grondwaterputten het dichtstbij bij de boorlocatie van de blowout nog altijd methaan in hoge concentraties aanwezig is ( $\max 44 \mathrm{mg} / \mathrm{l}$ ). Aangezien dit methaan een thermogene oorsprong heeft en de isotopensignatuur sterk lijkt op dat van het onderliggende gasreservoir, zijn deze hoge concentraties te verklaren door aanhoudende lekkage vanuit het onderliggende reservoir, veroorzaakt door de blowout.

In grondwatermonsters stroomafwaarts van de blowout waren de concentraties van zowel ijzer als mangaan sterk verhoogd. Ook bleken de stabiele isotoopverhoudingen van methaan in toenemende mate verrijkt met afstand stroomafwaarts van de blowout. Gezamenlijk toont dit aan dat er anaerobe oxidatie van methaan plaats vindt in het grondwater, gekoppeld aan de reductie van ijzer- als mangaanoxiden. Deze oxidatie draagt bij aan het verdwijnen van het opgeloste methaan uit het grondwater. Echter, de oxidatiecapaciteit van het watervoerende pakket is gelimiteerd door de hoeveelheid oxiden aanwezig in het geologisch sediment. Dit resulteert in een langzaam uitdijende pluim van opgelost methaan. Het thermogene methaan is waargenomen tot op slechts $500 \mathrm{~m}$ afstand van de blowout. Dit benadrukt dat het monitoren van methaan dient te gebeuren op een zo'n kort mogelijke afstand tot potentiële bronnen. 


\section{DE INVLOED VAN LATERALE GRONDWATER STROMING OP DOOR DE ONDERGROND LEKKEND METHAANGAS}

Het oplossen van methaangas in lateraal stromend grondwater blijkt een bijkomend, tot dusver over het hoofd gezien proces te zijn dat in de ondergrond het lot van methaan kan bepalen bij putlekkage (Hoofdstuk 5). Door gebruik te maken van numerieke simulaties in DuMux (een open source code voor de modellering van meerfase-stroming en transport) is dit proces in deze studie in detail geanalyseerd. Model simulaties zijn uitgevoerd die samen representatief zijn voor zandige watervoerende pakketten, karakteristiek voor de ondergrond van Nederland en sedimentaire bekkens elders in de wereld. De resultaten toonden aan dat de retentie van migrerend methaangas door oplossing zelfs al significant kan worden bij lage Darcy stroomsnelheden van $1 \mathrm{~m} /$ jaar. Zulke retentie was verwaarloosbaar in de afwezigheid van grondwaterstroming.

Retentie door oplossing was nog significanter bij een aantal extra simulaties van methaanmigratie door een heterogene opeenvolging van horizontale lagen variërend in permeabiliteit van klei tot zand. Afhankelijk van de opgelegde hydraulische gradiënt werden in deze simulaties methaanfluxen tot $10 \mathrm{~m}^{3} / \mathrm{d}$ (bij atmosferische druk en $10^{\circ} \mathrm{C}$ ) volledig opgelost in het grondwater, of duurde het enkele decennia tot het migrerende gas doorbrak aan de bovenkant van het modeldomein. Uit internationale studies blijkt dat waargenomen methaanfluxen bij lekkend olie- en gasputten over het algemeen aanzienlijk kleiner zijn dan deze waarde van $10 \mathrm{~m}^{3} / \mathrm{d}$. Deze studie heeft daarmee aangetoond dat niet alleen lagen met een lage permeabiliteit barrières kunnen vormen voor opwaartse gasmigratie, maar ook hoog permeabele zanden met bijbehorende hoge grondwater stroomsnelheden. Oplossing van opwaarts migrerend methaangas kan er dus mede voor zorgen dat het werkelijke voorkomen van gaslekkage onderschat wordt, met name als er enkel metingen aan het aardoppervlak worden uitgevoerd.

\section{IMPLICATIES}

Het risico van antropogene methaanlekkage zal per regio variëren en is afhankelijk van de hoeveelheid en integriteit van olie- en gasputten, de kwaliteit van het lokale grondwater, en de dichtheid van de bebouwing. Op basis van deze studie en recent werk door de toezichthouder SodM wordt geschat dat er in Nederland waarschijnlijk enkele tientallen tot zo'n 100 lekkende putten zijn. De cumulatieve methaanemissies uit deze putten zal hoogstwaarschijnlijk niet significant bijdragen aan de totale antropogene methaanemissie van Nederland. Echter, de lekkages kunnen lokaal wel een explosiegevaar vormen, zoals het geval was voor de lekkage ontdekt bij put MON-02, gesitueerd op een stuk land waar de bouw van een aantal huizen gepland stond in de nabije toekomst. De vervuiling van grondwater door methaanlekkage uit deze putten is onwenselijk, maar wellicht minder relevant omdat methaan al veelvoorkomend is in Nederlands grondwater, en bij de zuivering 
voor drinkwater productie wordt verwijderd. In vergelijking tot landen met een veel groter aantal vaak in slechte staat verkerende olie- en gasputten, zoals bijvoorbeeld in de VS en Canada, kan het risico van methaan lekkage uit olie- en gasputten daardoor als relatief klein beschouwd worden in Nederland. Echter, ook hier blijft het opsporen van lekkende putten belangrijk, ook met het oog op de veilige toepassingen van bijvoorbeeld geothermie en $\mathrm{CO}_{2}$ opslag.

Dit onderzoek toont aan dat het detecteren van methaan dat vanuit lekkende olieen gasputten naar boven migreert moeilijk blijkt te zijn, aangezien migrerend methaan beïnvloed wordt door meerdere processen die het in de ondiepe ondergrond kunnen vasthouden, verdunnen en afbreken, en daarmee de opwaartse stroming kan vertragen of zelfs stoppen. Idealiter vindt monitoring van methaanlekkage daarom plaats op een zo'n kort mogelijke afstand tot lekkage punten. In de praktijk zou dit betekenen dat er bij iedere olie- en gasput een toegewijde grondwatermonitoringsput zou moeten worden geplaatst en bemonsterd op meerdere dieptes. Aangezien er wereldwijd reeds miljoenen olie- en gasputten zijn is een meer pragmatische aanpak gewenst. De in dit onderzoek opgedane inzichten geven handreikingen voor hoe zo'n monitoringsprogramma eruit zou kunnen zien. Echter, ongeacht de meetmethode zal door de eerder genoemde processen een deel van de lekkende putten onopgemerkt blijven. 



\section{List of Publications}

\section{Chapters of this dissertation}

Schout, G., Hartog, N., Hassanizadeh, S. M., Griffioen, J. (2017). Impact of an historic underground gas well blowout on the current methane chemistry in a shallow groundwater system. Proceedings of the National Academy of Sciences of the United States of America, 115(2), 296-301. https://doi.org/10.1073/pnas.1711472115

Schout, G., Griffioen, J., Hassanizadeh, S. M., Cardon de Lichtbuer, G., Hartog, N. (2019). Occurrence and fate of methane leakage from cut and buried abandoned gas wells in the Netherlands. Science of The Total Environment, 659, 773-782. https://doi. org/10.1016/j.scitotenv.2018.12.339

Schout, G., Hartog, N., Hassanizadeh, S. M., Helmig, R., Griffioen, J. (2020). Impact of groundwater flow on methane gas migration and retention in unconsolidated aquifers. Journal of Contaminant Hydrology, (January). https://doi.org/10.1016/j. jconhyd.2020.103619

Schout, G., Griffioen, J., Hartog, N., Eggenkamp, H. Cirkel, G. (2020). Controls on groundwater methane occurrence and origin from shallow aquifers to deep formation waters in the Netherlands. To be submitted.

\section{Other publications}

Schout, G., Drijver, B., Gutierrez-Neri, M., Schotting, R. (2014). Analysis of recovery efficiency in high-temperature aquifer thermal energy storage: a Rayleigh-based method. Hydrogeology Journal, 22(1), 281-291. https://doi.org/10.1007/s10040-013-1050-8

Schout, G., Drijver, B., Schotting, R. (2016). The influence of the injection temperature on the recovery efficiency of high temperature aquifer thermal energy storage: Comment on Jeon et al., 2015. Energy, 103. https://doi.org/10.1016/j.energy.2016.02.122

\section{Conference presentations}

Schout, G., Hartog, N., Hassanizadeh, S. M., Griffioen, J. (2017). Environmental legacy of an underground gas well blowout: long-term effects of gas and brine leakage on groundwater quality. EGU General Assembly 2017. Oral presentation. 
Schout, G., Griffioen, J., Hassanizadeh, S. M., Hartog, N. (2017). In search of thermogenic methane in groundwater in the Netherlands, with emphasis on the location of a historic gas well blowout. AGU Fall Meeting 2017. Oral presentation.

Schout, G., Griffioen, J., Cardon de Lichtbuer, G., Hartog, N. (2018). Detecting gas leakage in the critical zone at fully decommissioned hydrocarbon wells in the Netherlands. EGU General Assembly 2018. Poster presentation.

Schout, G., Hartog, N., Hassanizadeh, S. M., Griffioen, J. (2018). 3D modelling of subsurface methane leakage through unconsolidated sedimentary aquifers; implications for environmental monitoring. IAH Congress 2018. Oral presentation.

Schout, G., Hartog, N., Griffioen, J., Hassanizadeh, S. M. (2019). 3D modelling of subsurface methane leakage through unconsolidated sedimentary aquifers; implications for environmental monitoring. EGU General Assembly 2019. Oral presentation.

\section{Publicity in newspapers}

Schoonen, W. (2017, December 27). Drentse boorput lekt na 50 jaar nog steeds gas. Trouw.

ter Voorde, M. (2017, December 27). Nog altijd lekt er aardgas in Sleen. De Volkskrant.

Vermeer, F. (2017, January 26). Bouw bij Molenslag vertraagd door gas. AD Westland.

van der Walle, E. (2019, January 30). Toezichthouder: strengere regels bij sluiten gasputten. NRC Handelsblad. 


\section{Dankwoord / Acknowledgements}

Het begon allemaal met een sollicitatie gesprek via skype, in April 2015. Ik belde in vanuit mijn woning in een torenhoog flatgebouw in Doha, Qatar. Na mijn afstuderen aan de Universiteit Utrecht in 2012 had ik hier mijn eerste echte baan als geohydroloog gevonden. Dezelfde dag nog kreeg ik reactie - Niels, Majid en Jasper waren al overeen gekomen dat ik het mocht gaan doen. Voor mij een grote eer, en mijn wens om me nog verder te kunnen verdiepen in de waterwetenschap kon in vervulling gaan. Niet veel later, in Juli 2015, was ik dan ook al terug in Nederland en ging ik aan de bak. In de vijf jaar die hierop volgde heb ik net als alle PhD's zo mijn pieken en dalen meegemaakt. Maar ik heb nooit getwijfeld aan het vertrouwen van mijn promotoren. Ik wil dan ook beginnen met jullie hiervoor hartelijk te bedanken.

Niels, bedankt voor je aanstekelijke enthousiasme. Als ik er weer een week op had zitten waar ik dit enthousiasme zelf kwijt was geraakt kreeg je mij hiermee elke vrijdag weer op de rit. Daarnaast hebben je kritische blik en de daardoor scherpe inhoudelijke discussies die we voerden over te publiceren artikelen natuurlijk zeer veel bijgedragen aan de kwaliteit van dit onderzoek. Vrijdagmiddag borrels inclusief jamsessies met 'The (Original) Aardbevers' zorgen dan weer voor het nodige vertier! Hoop dat we dit de komende jaren als zowel collega's en mede-Zuilenaren door kunnen zetten, bijvoorbeeld met \#Kanaal-sessies.

Jasper, bedankt dat je deur altijd open stond voor mij, en dat ik altijd bij je terecht kon voor inhoudelijke vragen en om mijn ideeën bij je te toetsen. Ik heb me vaak verbaasd over jou bijna encyclopedische kennis van alles wat met de ondergrond te maken heeft, waarmee je me zo vaak de goede richting in hebt gestuurd. Daarnaast hield je altijd de voortgang van mijn promotie in zijn geheel in de gaten, en hoe het mij persoonlijk afging, wat ik zeer waardeer. Gelukkig zullen we elkaar ook in mijn nieuwe functie zo nu en dan tegen blijven komen.

Majid, bedankt voor alle keren dat je hebt geholpen om voor mij ondoorgrondelijke formules en papers toch te kunnen te doorgronden, en de hierbij altijd voorradige Perzische versnaperingen. Minstens net zo belangrijk voor mij is dat de geohydrologie groep onder jou leiding en dat van Ruud al sinds mijn Master als een thuis voelt. Ook hiervoor ben ik je dan ook zeer dankbaar.

Dan mijn collega's bij de geohydrologie groep. Jan en Thomas - de andere (Original) Aardbevers - bedankt voor de gezellige jamsessies en etentjes bij de Griek. Giannis, it was great to have a colleague with whom you can discuss in detail the result of any major cycling race world-wide, and with whom you can even go for a ride yourself every now and then. Of course also Ruud, Enno, Annuska, Vahid, Suzanne, Alraune, Leifei, Hamed, Amir, Amir, Johan, Willem-Bart, Matthijs, Lucas, Xiaoguang, Luwen - sorry if I forgot someone - thanks for all the good times and discussions at lunch, in coffee breaks and at conferences. 
Mijn collega's bij milieuwetenschappen. Floris, super om een kamergenoot te hebben op kantoor met wie je als PhD-er zoon beetje gelijk oploopt, en waarmee je alle tactieken, hobbels en twijfels kunt bespreken. Bedankt voor alle goede gesprekken en de gezelligheid. John, Feroz, thanks for all the fun times we had around the coffee table on the $8^{\text {th }}$ floor of the new Vening Meineszbuilding. Verder alle collega's bedankt voor de goede werksfeer, teveel om allemaal op te noemen maar zeker Svenja, Mara, Annick, Jetske, Paul, Dominique, AnnHelene, Ineke, Remon, Yasmina, Elizabeth en Myrna.

Mijn nieuwe collega's van team geo bij KWR wil ik bedanken voor de gastvrijheid die ik bij jullie heb mogen ervaren. Ondanks dat ik'slechts' gastmedewerker was heb ik de werksfeer als zeer prettig ervaren, en ook uitnodigingen voor teamuitjes en Ardennenweekenden heb ik zeer gewaardeerd. Ik kijk uit naar de samenwerking nu dat ik officieel lid van het team ben geworden.

For this research I collaborated with many people both in the Netherlands and abroad. Rainer, Dennis, Martin, Timo and other colleagues in Stuttgart. To have a group of people that help others without asking for much in return is really special. The hospitality shown during my two visits to your university made my stay in Stuttgart memorable. Hans Eggenkamp, thanks for your patience in teaching me the ways of the chloride stable isotopes measurements, and inviting me to come work at the IPGP in Paris. At the lab in Utrecht, many people helped me out tremendously with the analysis of groundwater samples. In particular I have to thank Thom Claessen, without whom I could not have done that and who was also always available to reflect on field methods and help built the required tools. Julia and Aleksandra, although we had some difficulties with our spin-off project in Limburg, you were great colleagues and I really enjoyed working together. Finally, a number of students collaborated with me on this study, and helped me with both field and lab works. Cynthia, Guillaume, Paulina and Stijn - thanks a lot for this.

I have to also thank some former Schlumberger Water Services colleagues here, but in particular Boris and Leslie, who were mentors to me during my time in Doha and whose example inspired me to apply for a PhD. You showed a lot of confidence in me for which I am really grateful. Thanks to the others in the team there as well - it was a great time for me and I was sad to leave you guys.

Dan de vele vrienden die ervoor zorgden dat ik mijn onderzoek in het weekend en op vakanties ook weer even kon vergeten. Daniel, Reynier, afgelopen jaar is met onze rondreis in de VS een wens in vervulling gekomen waarvan de kiem al jaren terug gelegd was. Een onvergetelijk avontuur, een van de vele die ik inmiddels met jullie heb meegemaakt. Op nog veel meer avonturen samen. Stay safe out there. Clement, love you, grande bisous, hope you keep finding your way back to Utrecht from time to time or else I have to keep going back to Qatar to see you. Boris, here's to more good times together, and hopefully, eventually, we can work together in hydrogeology again some time. Danny en Pim, dank dat jullie mij altijd terug welkom heten bij mijn roots in Den Haag en Zoetermeer. Super om vrienden te hebben wie je je echte passies kan delen; basketballen en chillen. Niet te vergeten de andere ex-Middelburgers en Koestraat-familie: Char, Giulia, Loes, Jessica, Kevin, Toby, Jason, Arno, 
Timon. Soms uit het zicht maar nooit uit het hart. Super om vrienden te hebben waarmee je goed kan feesten en oude tijden doen herleven.

Mijn nieuwe familie. Mart en Leonie, bedankt voor de gezelligheid, het lekkere eten, en de muziek in jullie knusse huis in Nieuwkoop en op vakantieadressen in Frankrijk en Italië. Hella, dankjewel dat je er altijd bent voor mij en voor Dina. Wat een luxe om zo'n goede binnenshuis architect en art-designer te hebben! Anne en Jacco, zo fijn om zulke goede vrienden in de buurt te hebben waar je altijd terecht kan en gewoon op de bank of in de tuin neer kan ploffen. Dank dat ik surrogaat ouder van jullie dochters mag zijn. Mina Maria (Prins Grote Zus) en Lenny, vanaf dag 1 zitten jullie in mijn hart, bedankt dat jullie altijd met mij willen spelen en (bijna) altijd vrolijk zijn.

Pa, ma, Paul, Kirsten (en Kuma). Wat heb ik een mazzel met zulke lieve familie, die mij altijd onvoorwaardelijk steunen en mij al vanaf dat ik klein ben doen geloven dat ik alles kan bereiken wat ik wil, maar dat gelukkig zijn het allerbelangrijkste is (en die ook nog eens allemaal op loopafstand van het strand wonen in de leukste stad van Nederland). Ondanks dat we behoorlijk wat te verduren hebben gekregen de afgelopen jaren, ben ik zo blij dat we altijd leuke dingen zijn blijven doen met zijn allen. Heel veel zin in nog meer strandwandelingen, concerten, weekendjes weg, visbarbeques op het dakterras, en nog veel meer.

Dina, ik hou met heel mijn hart van jou. Ik krijg elke dag meer respect voor jou en waardering voor hoe je in het leven staat en alles aanpakt. Daar leer ik zoveel van. Dat je ook op je $21^{\mathrm{e}}$ vanuit het $\mathrm{HBO}$ zo een PhD instroomde en het flikte om binnen 4 jaar te promoveren, daar heb ik met terugwerkende kracht nog zo veel meer respect voor gekregen. Toen ik 5 jaar geleden hieraan begon was dat voor ons ook gelijk het begin van een nieuw tijdperk samen. Achteraf zo blij dat alles gegaan is hoe het gegaan is, want ik ben zo gelukkig met het leven dat we samen hebben opgebouwd, en heb megaveel zin in de toekomst. 



\section{Curriculum Vitae}

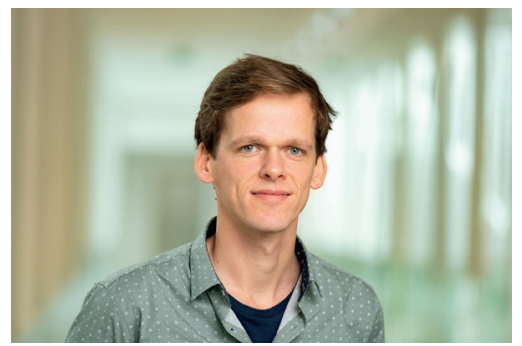

Gilian Schout was born in The Hague on January 25th, 1988, but grew up mostly in nearby Zoetermeer until he was 18. In 2006 he obtained his VWO degree at the Erasmus College in Zoetermeer. He then moved to Middelburg to study at the University College Roosevelt (formerly known as the Roosevelt Academy). There, he obtained a Bachelor of Science degree in 2009, majoring in Earth Sciences and Biology. He then moved to Utrecht, where he graduated from the Masters of Hydrology in 2012, with a focus on hydrogeology. For his MSc thesis research he spent 6 months in Oman, studying sea water intrusion and groundwater depletion in and around the rapidly growing coastal city of Sohar. He also conducted an internship at IF Technology, Arnhem, on the energy storage efficiency of high temperature aquifer thermal energy systems. This eventually culminated in his first scientific publication in 2014. For a short period after his graduation he worked as a junior teacher for the Earth Sciences department at Utrecht University.

He started his professional career in 2013 when he obtained a job a as hydrogeologist for Schlumberger Water Services in Doha, Qatar. From there, he carried out applied hydrogeological work throughout the Gulf Region, consisting of water-quality monitoring, groundwater modelling, and supervising the design and drilling of groundwater wells, in the context of large scale groundwater projects including wellfield rehabilitation and ASR systems. In 2015 he applied for and was granted a position as PhD at Utrecht University, shared between the Environmental Science and Environmental Hydrogeology groups. The PhD was part of larger research project called 'Shale Gas and Water', funded by the Dutch Research Council (NWO) and a number of Dutch drinking water companies. His PhD work focused on the effects of methane leakage caused by oil and gas production, the results of which are presented in this dissertation. In 2020 Gilian was awarded with the 'NHV Hydrologieprijs' by the Dutch Hydrological Society (NHV), for his paper on the effects of methane leakage caused by the gas well blowout in Sleen, Drenthe. This award is given once every three years to a young Dutch or Belgian researcher in hydrology. In January 2020, Gilian started work as a researcher for KWR Water Research institute in Nieuwegein, the Netherlands. 


